SZEGEDI TUDOMÁNYEGYETEM

TERMÉSZETTUDOMÁNYI ÉS INFROMATIKAI KAR

FÖLDTUDOMÁNYOK DOKTORI ISKOLA

\title{
A barlangklíma tér- és időbeli változásainak vizsgálata különböző magyarországi karsztterületeken
}

Csépe-Muladi Beáta

Témavezető

Dr. habil. Mucsi László

egyetemi docens

Szeged

2016 
1. Bevezetés, problémafelvetés, célkitüzés..............................................................................5 5

2. Irodalmi elözmények ................................................................................................................9

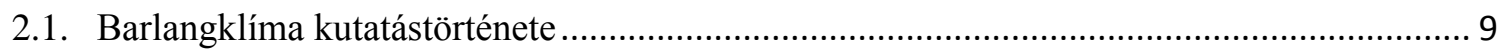

2.2. Barlangok néhány fontos klimatológiai jellemzője .......................................................... 12

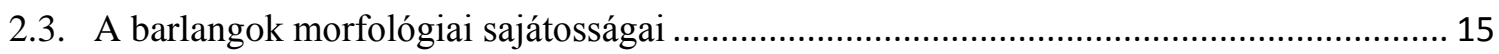

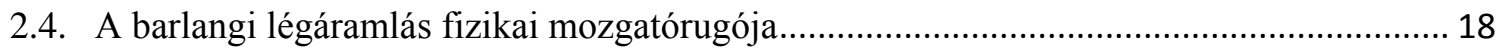

2.5. Barlangok geometriájának köszönthető módosított légáramlás …………............................. 23

3. Mintaterület bemutatás …....................................................................................................... 26

3.1. A barlangokat befogadó hegységek bemutatása............................................................ 26

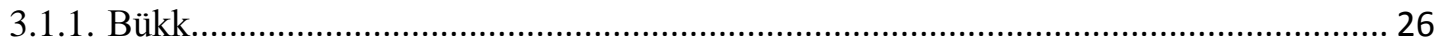

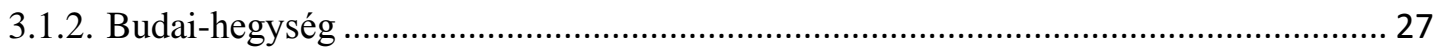

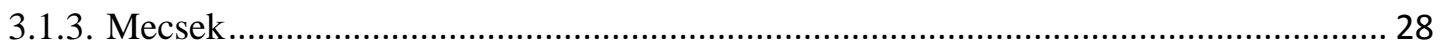

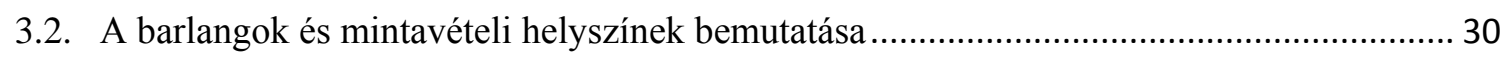

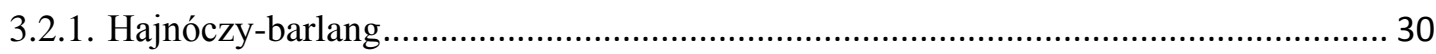

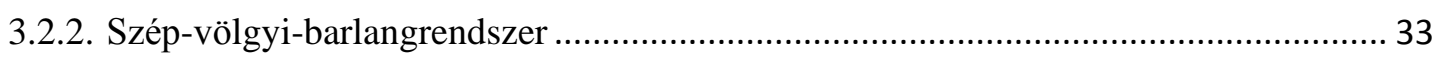

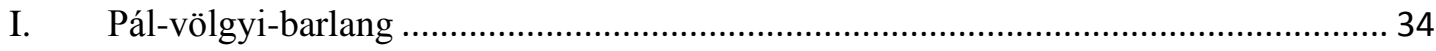

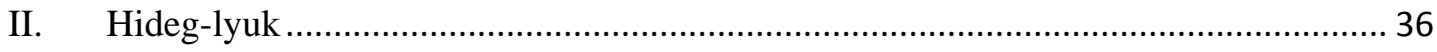

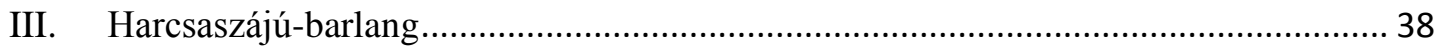

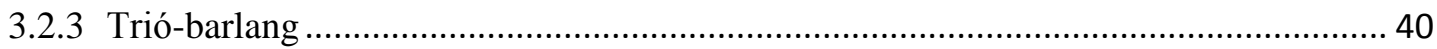

4. Vizsgálati módszerek .........................................................................................42

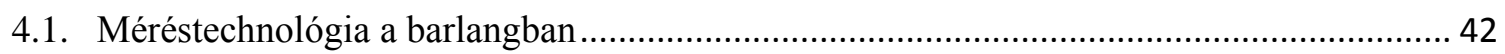

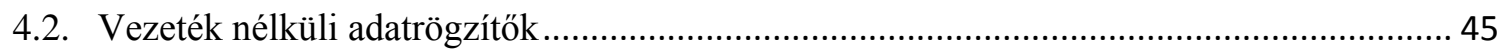

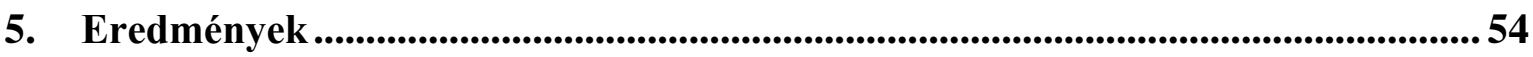

5.1. A barlangok vizsgált pontjainak bemutatása a tengerszint feletti magasság és léghőmérséklet tükrében 54

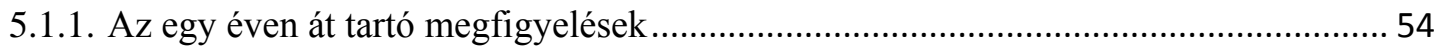

I. Hajnóczy-barlang vizsgálati pontjainak tengerszint feletti magassága és hőmérséklete .... 55

II. Hideg-lyuk vizsgálati pontjainak tengerszint feletti magassága és hőmérséklete .............. 56

III. Pál-völgyi-barlang vizsgálati pontjainak tengerszint feletti magassága és hőmérséklete 58

5.1.2. Időszakos megfigyelések .

I. Harcsaszájú-barlang vizsgálati pontjainak tengerszint feletti magassága és

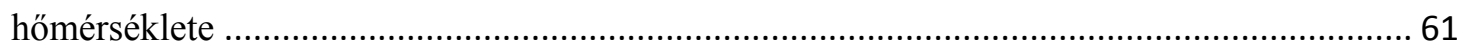

II. Trió-barlang vizsgálati pontjainak tengerszint feletti magassága és hőmérséklete ............ 63 
III. Hideglyuk-Gábor Áron vizsgálati pontjainak tengerszint feletti magassága és hőmérséklete

IV. Hideg-lyuk-Rézágyú-terem vizsgálati pontjainak tengerszint feletti magassága és hömérséklete

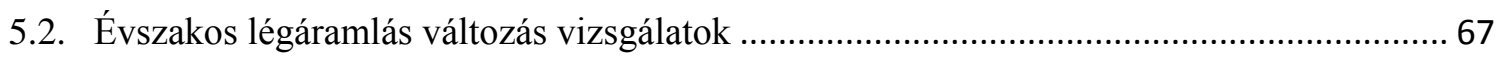

5.2.1. A Hajnóczy-barlang hőmérsékletének éves menete …………………........................67

5.2.2. A Hideg-lyuk hőmérsékletének éves menete ......................................................... 71

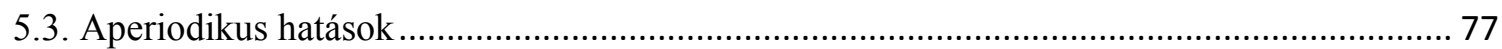

5.2.1. Hajnóczy-barlang antropogén hatás mértéke........................................................... 77

5.2.2. Az antropogén hatás mértéke a Trió-barlangban ....................................................... 85

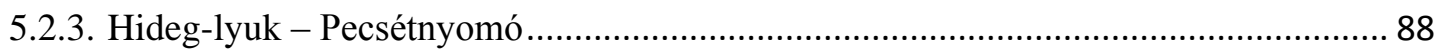

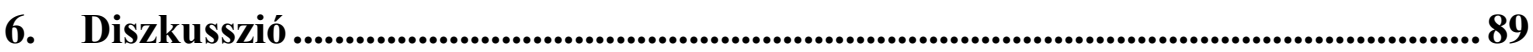

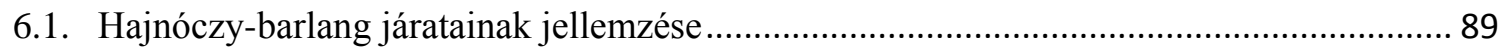

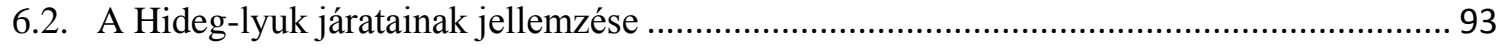

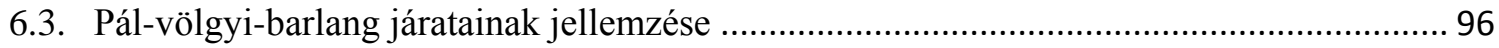

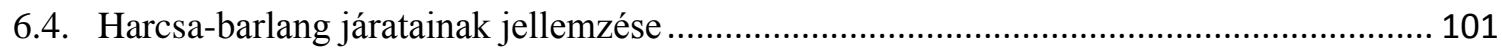

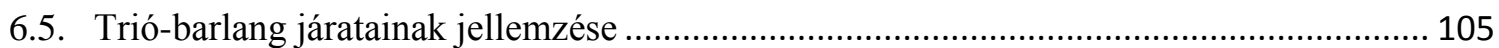

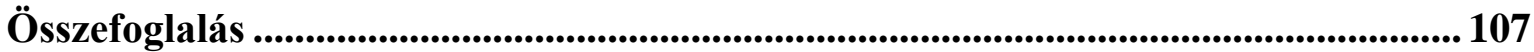

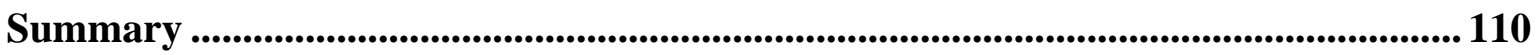

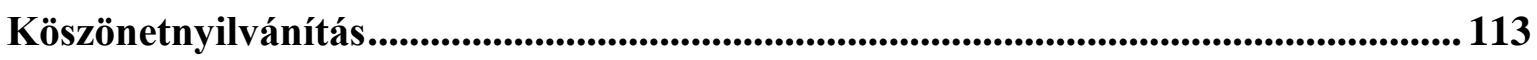

Irodalomjegyzék .................................................................................................................. 115

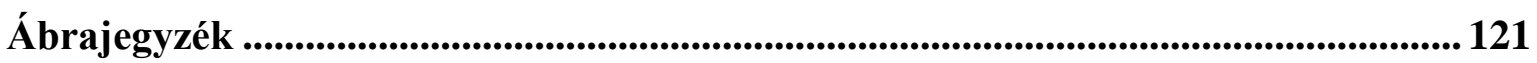

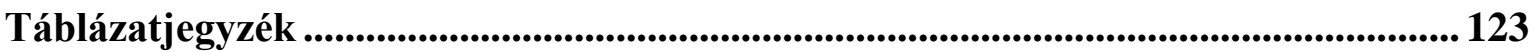

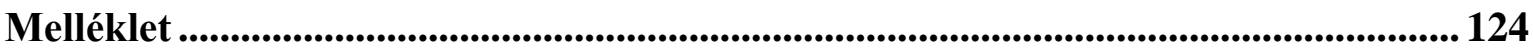


„.. a barlang is él, lélegzik, fejlődik, időről-időre változtatja arcát."

Jakucs László 


\section{Bevezetés, problémafelvetés, célkitűzés}

„A karszt a mészkőnek és a hozzá kapcsolódó jelenségeknek a fejlödési állapota, formája, amely a közet-minőség és a térben-időben változó geológiai, geográfiai klimatológiai és biológiai környezeti feltételek, és okok komplex hatásaként jön létre és alakul tovább" (Jakucs, 1971).

A földtudományok jelentős kutatási területe a karsztok és a karsztosodás. A karsztosodás folyamata során a karbonátos-kőzetek oldódása és elszállítódása zajlik le. A karsztosodás mértékét jelentősen befolyásolja, hogy mely éghajlati övön található a karsztterület és ott milyen az időjárás szezonális változása, mennyi a lehullott csapadék, mely vegetáció a meghatározó, és mekkora a párolgás mértéke. Az egyes karszt terület elhelyezkedését tekintve ezek a paraméterek igencsak eltérőek lehetnek. A karszt terület tengerszint feletti magassága, a domborzat alakja és a lejtőkitettsége, mind befolyásolja a hőmérsékleti viszonyokat, a napsugárzást, különböző hőmérsékletű légáramlást.

Barlangnak nevezünk minden olyan üreget, mely természetes úton jött létre a Föld szilárd kérgében, valamint 2 méternél nagyobb és ember által járható. A 1996. évi LIII. természetvédelmi törvény úgy határozza meg, hogy minden barlang exlege védett természetvédelmi terület. Ez a védelem kiterjed a barlang bejáratára, teljes járatrendszerére, befoglaló kőzetre, képződményeire, formakincsére, bármilyen halmazállapotú kitöltésére, természetes élővilágára, mesterségesen létrehozott, bejárati, vagy barlangrészeket összekötő szakaszára (Csepregi, Gazda, 2014). Nagyobb karsztterületeink védelmét nemzeti parkok biztosítják, sőt az Aggteleki- és a Budai karszt emellett a világörökség részét is képezi.

Magyarország gazdag karsztos formakinccsel rendelkezik. A felszíni és a felszín alatti karsztjelenségek tudományos vizsgálata a 20. sz. közepén indult Kessler Hubert és Jakucs László tevékenységével.

Különösen jelentős a hazai karszt és barlangkutatás eredményeiből a karsztok komplex geomorfológiai értelmezése (Jakucs, 1977; Hevesi, 1991), a termálkarsztos területek vizsgálata (Leél-Össy, Surányi, 2003) a talaj hatás elemzése (Bárány-Kevei, Mucsi, 1995; Zámbó, 1993), a barlangi radonkoncentráció éves változásának vizsgálata (Somogyi, et al., 1983, Hakl, et al., 1997), a barlangok gyógyhatásának elemzése (Horváth, 
1984), a barlangklíma vizsgálata (Fodor, 1981), valamint a hideg karsztok morfometriai jellemzése (Veress, 2009).

A sztatikai és dinamikai törvények alakítják a nagy földi légkörzést, ezek hatnak a barlangi levegő fizikai állapotán bekövetkező változásokra is. A barlangok légterében lezajlódó fizikai folyamatoknál ki vannak zárva a váratlan, gyors egyik percről a másikra történő időjárási hatások, erőteljesebb felmelegedések, lehülések sokkal tompítottabban jelennek meg. (Fodor, 2002)

„A barlangklíma a szilárd földkéreg közeteiben természetes úton létrejött üregek légterének sajátos klímája" (Fodor, 1981). A barlang léghömérséklete rendszerint megközelíti a felszíni évi átlaghőmérsékletet, valamint a barlangi légterek levegője évszakosan változó intenzitással cserélődik a külső légtérrel, de ez a légcsere nem akadályozza meg a sajátos barlangklíma kialakulását. Ehhez hozzájárul az is, hogy a barlangok bejáratai is sokban különböznek egymástól: tengerszint feletti magasságuk, méretük, elhelyezkedésük lehet völgytalpon, a hegyoldalban, vagy hegytetőn, kitettségük, és bejárataik száma sem egyforma. A barlangjáratok morfológiája is hatással van a sajátos barlangklíma kialakulását, mivel a különböző nagyságú, és alakú barlangjáratok máshogy reagálnak a barlangi légkörzésre (Stieber, 2014). A növénytakaró is befolyásolja a hőmérsékletviszonyokat, a sűrű lombkoronájú erdők visszafogják beeső napsugarakat, így a léghömérséklet is jelentősen kiegyenlítettebb, mint egy nyílt karsztos lejtőn (Zelinka, Stieber, 2014). A léghőmérséklet térbeli eloszlása is változatos, hiszen az egyes termek, folyosók sincsenek egy magasságban, így elindul egy ún. belső cirkuláció (Fodor, 1981).

A barlangi levegő folyamatosan cserélődik a felszíni hőmérséklet hatására, de minden barlangnak más a légkörzése, így teljesen egyedi barlangklíma alakul ki. A barlangok klímájának mérése és vizsgálata jelenősen előreviszi a barlangi környezet hatótényezőinek megismerését.

Napjainkban a klímaváltozás egyre sürgetőbb problémái kerülnek elötérbe, így felmerül az a kérdés, hogy ha a felszínen a klímaváltozás szélsőségeivel küzdünk, az aszályos éveket a bő csapadékos évek váltják, akkor mindez hogyan érvényesül a barlangi körülmények között.

Már kimutatták a barlangok jótékony hatását, ami annak köszönhető, hogy a hőmérséklet $10^{\circ} \mathrm{C}$ körüli és magas páratartalom jellemzi. Ez a csíramentes környezet már rengeteg felső-légúti betegségben szenvedő embernek segített a betegség tüneteinek csillapításában, vagy vezetett teljes gyógyuláshoz (Jakucs, 1959). A hosszú távú barlangi 
klímaparaméterek mérésével választ kaphatunk arra kérdésre, hogy vajon a felszínen végbemenő klímaváltozás veszélyezteti-e a barlangok klímájának változását, amivel gyógyhatása is összefügg.

Dolgozatomban az alábbi célokat jelöltem ki:

1. Egyre több nemzetközi természetvédelmi program foglalkozik a barlangok megóvásával. A Rózsadombi termálkarszt hatékonyabb védelme érdekében a Pálvölgyi-barlangban 1995-ben komplex monitoring rendszert építettek ki (PHAREprogram keretén belül), a tervezett mérések között barlangklíma paraméterek is szerepeltek. Az akkori technikai adottságokkal időigényes és fárasztó munkát jelentett a kábelek elhelyezése (Bekey, 1995), s a rendszer a magas páratartalom miatt működésképtelenné vált. A technika fejlődésével olyan automata vezeték nélküli adatgyüjtőket hoztak létre, melyek könnyedén kihelyezhetők még pontosabb képet nyújtanak a barlangklíma változásokról. A doktori disszertációmban a módszertanilag is újdonságnak számító, vezeték nélküli szenzorhálózatok eszközét, az UC Mote Mini alkalmazhatóságát vizsgálom barlangi körülmények között.

2. Célom volt különböző genetikájú és morfológiájú barlangok mikroklímájának feltérképezése és összehasonlítása. Három karsztterületen elhelyezkedő barlangot választottam ki a vizsgálatra: egy hidrotermális karszton hévizes eredetű (Budaikarszt: a Pál-völgyi-barlangrendszer tagjai közül a Pál-völgyi-barlang, a Hideg-lyuk és a Harcsaszájú-barlang), egy felszín közeli (Bükk- Hajnóczy-barlang) és egy víznyelő barlangot (Mecsek- Trió-barlang). A vizsgált barlangokban elözetesen szórványos mérések, illetve radon mérések már voltak, de hőmérséklet monitoring hálózat kiépítésre ezekben a barlangokban még nem került sor.

3. Kutatásaim során vizsgáltam a tengerszint feletti magasság, és a hőmérséklet rétegzettségnek kapcsolatát (Muladi, Mucsi , 2013). A Morva-karszton található Macocha-barlang bejáratánál a sziklafalon 2008-ban tanulmányozták a mikro klimatikus viszonyokat. A barlang $138,4 \mathrm{~m}$ mély sziklafalán, a téli-nyári hőmérsékleti profil bemutatta a hőmérséklet rétegződését a különböző évszakokban, és az is bebizonyosodott, hogy a tengerszintfeletti magasság függvényében mennyire változékony a hőmérséklet (Litschmann et al., 2012). A fizikai törvényszerüségnek megfelelően, a barlangban is alulról felfelé növekszik a hőmérséklet, a növekedés mértéke azonban differenciált képet mutat (Fodor, 1981). Fodor a Baradla-Domica-barlang levegő rétegzettségének vizsgálata során a legnagyobb vertikális különbséget a bejárati térségben mérte, mely $0,4{ }^{\circ} \mathrm{C}$ volt 
140 cm-en. Badino (2010) az olaszországi barlangokban vizsgálta a hőmérséklet tengerszint feletti magasság szerinti eloszlását, ahol bebizonyosodott, hogy nem lineáris a kapcsolat a tengerszint feletti magasság és hőmérséklet között.

4. A bejárattól számított távolság alapján három különböző szakaszt különíthetünk el a barlangokban: 0-2 m-ig télen lehülési, nyáron felmelegedési szakaszt; 2-14 m-ig örvénylési szakaszt; 6-14 m-ig felmelegedési szakaszt, ahol a barlangi légkörzés dominál (Kordos, 1970). A precíziós mérések alapján viszont lehetőség van ennek a gondolatmenetnek a megfordítására. Ez esetben a napi és az éves hőingás alapján határoljuk le a szakaszokat. A hőmérséklet változékonyságának függvényében, barlangonként a bejárattól számított távolság alapján, az adottságoknak megfelelően történik kijelölésük.

5. Célom volt a barlangi léghőmérséklet időbeli változásainak vizsgálata, hiszen ez lehetővé teszi a hőmérséklet hosszú (évszakos) változásainak leírását. A barlangjáratok léghőmérséklete különböző mértékben követi a felszíni léghőmérséklet periodikus változását. A barlangok egyes szakaszainak mikroklímája napi, szezonális, és éves szinten eltérően reagál a felszíni hőmérséklet-változásra, így a különböző járatok léghőmérsékletének időbeni változásáról is képet kaphatunk (Kordos, 1970).

6. A barlangok kedvező mikroklímája tette lehetővé a sokféle hasznosításukat (Keveiné, 2009). Barlanghasznosítás szempontjából is fontos a klíma paraméterek mérése, mivel a turisztika számára megnyitott barlangokban az oda érkező barlanglátogatók a barlangi klímára hatással vannak (Smith, et al., 2013). A klímamérések segíthetik a Nemzeti Parkok barlangjainak turisztikai hasznosítását, mivel olyan optimális csoportlétszámot tervezhetnek, amely nem jelent a troglobiont fajok sérülésével járó hőtöbbletet. Az aktívan kutatott barlangok esetében a barlangászok okoznak hőmérsékleti anomáliát a gyakran több órás intenzív fizikai munkával. Céljaim között szerepel az aperiodikus változások mértékének meghatározása a különböző barlangokban, a látogatócsoportok okozta antropogén hatás mértékére vonatkozóan, illetve a kutatók tevékenységéből származó hőtöbblet meghatározása szempontjából. Egy adott terem szellőzésének mértéke meghatározható azon időtartam ismeretében, amely alatt a hőmérséklet és a páratartalom a látogatások után az eredeti állapotra visszaáll. Ezek az adatok értékesek lehetnek a barlangkutatásban, segíthetnek megérteni a legtöbbször bonyolult barlangi járatok légmozgásának jellemzőit is. 


\section{Irodalmi előzzmények}

\subsection{Barlangklíma kutatástörténete}

A barlangklíma kutatástörténete a hazai barlangok klímájára vonatkozóan nagy múltra tekint vissza. A Baradla-barlangban jegyezték fel a Styx-patak hőmérsékletének első adatait (Townson, 1797). Raisz Keresztély Gömör vármegye megbízottja a Baradlabarlangról készített leírásában feljegyzi a patak hőmérsékletét is (Kessler, 1941). A XIX. sz. végén egyre több kutató foglalkozott már a barlangok kialakulásával, fejlődésével általános leírásával, osztályozásával, egyre több szakirodalomban lelhető fel a hőmérséklet időszakos megfigyelése.

A háború utáni időkben rohamosan fejlődtek a müszerek, és az egyre pontosabb mérések segítségével megértették, hogyan lehet optimalizálni a szellőztetést (Hartman, 1961). A bányákban a széles, egységes keresztmetszettükkel, jól meghatározott geometriájukkal könnyebben definiálható a légkörzés, mint a természetes barlangjáratoknál. Ez a probléma sok nemzet barlangászát és bányászát foglalkoztatta, akik feljegyezték tapasztalatokon alapuló elméleteiket. Ezeket a korábbi, tapasztalati úton történő beszámolókat Trombe (1952) és Cullingford (1953) foglalták össze. A természetes légáramlást már épületgépészek is alaposan vizsgálták, de úgy találtak, ez egy egyszerü geometriai helyzet, mégis nehéz mennyiségi modellt felállítani. A szélcsatornák és méretarányos modellek segítségével próbálták pontosítani ezeket. (Linden, 1999). Ezzel párhozamosan kezdődtek el a földalatti járatok légkörzésének fizikai vizsgálatai, mivel a bánya szellőztetés szempontjából nagyon fontos volt minél több ismeretet szerezni erről.

Későbbiekben fizikai alapú modelleket fejlesztettek (Cigna, 1967; Wigley, Brown, 1976), de a barlangok komplex geometriája akadályozta analitikai megoldások létrejöttét, eltekintve néhány esettől (Wigley, 1967; Atkinson, 1983). Napjainkban a monitoring jellegü tanulmányok a gyakoriak, amelyekből meghatározhatjuk a légáramlás mintázatát, majd ezek naprakészen bemutathatók.

Fodor Istvánnak 1981-ben jelent meg barlangklimatológiai mérésit bemutató könyve, melyben a hazai és külföldön elvégzett barlangi klímamérések alapján a barlangokat az ott tartózkodó ember közérzetének figyelembevételével, a barlangterápia szempontjából négy klimatikus csoportba sorolta: 
1. hidegérzetet keltenek a poláris és szubpoláris, illetőleg a magashegységi övezetben nyíló barlangok, valamint a mérsékelt övi klímatartományban állandóan, vagy időszakosan jéggel kitöltött barlangok pl. Dobsinai-jégbarlang;

2. hüvösérzetet keltenek a mérsékelt övi kontinentális klímatartomány zömmel alacsony középhegységi övezetébe tartozó magyarországi karsztbarlangok, amelyek Európában itt hasznosíthatók leginkább barlangterápiára;

3. komfortérzetet keltenek a mediterrán és a nedves szubtrópusi területek barlangjai, továbbá az ezeknél hủvösebb éghajlati övek termálbarlangjai. Magyarországon ebbe a típusba tartoznak a termálvizes barlangok pl. Miskolctapolca, Tapolcai-tavasbarlang

4. melegérzetet keltenek a trópusi éghajlati öv barlangjai és a nagy hőfokú termálbarlangok, ahol az évi középhőmérséklet $20^{\circ} \mathrm{C}$ felett van.

A fenti csoportosítás egy a sok lehetséges közül. Bárhogyan osztályozzuk is azonban a barlangokat, a szpeleometeorológia bebizonyította: ahány barlang, annyi sajátos föld alatti mikroklíma-rendszer létezik.

Jakucs László és Markó László 1956-ban - az aggteleki Béke-barlang bejáratánál fellépő légáramlat tanulmányozása során - arra a következtetésre jutottak, hogy a barlangot fedő kőzetréteg a levegő számára átjárható. Mivel a kőzet belsejében, valamint a felszínen általában más-más hőmérséklet uralkodik, a repedésekben, valamint a barlang bejárata felett elhelyezkedő légrétegek között fellépő sűrüségkülönbség légnyomáskülönbségeket hoz létre (kéményhatás megfigyelése).

Azon barlangokban, melyeknek a járatai közel vízszintesek, és bejáratuk alacsonyabban helyezkedik el, mint a hegytető, nyáron a kifelé áramló levegő az uralkodó, mivel a barlangban és a kőzet repedéshálózatában sűrü hideg levegő található.

Jakucs és Markó a Baradla-barlang esetében a nyomáskiegyenlítő légáramlást is feljegyezte, mely szerint a bejárati szakaszon történik a nyomás kiegyenlítődés, mivel a több száz méter vastag kőzetréteget impermábilisnak feltételezték (1. ábra). A zsomboly, kürtők esetében a konvenkciós légáramlással magyarázzák a légmozgást (Markó, Jakucs, 1956).

Jakucs László 1959-ben a Béke-barlangban gyógyhatás vizsgálatokat folytat, melynek következtében 1969-ben gyógybarlanggá is nyilvánítják (1. táblázat). A barlang levegőjének magas kalcium-ion tartalma gyulladáscsökkentő és görcsoldó hatással bír, az átlagosnál magasabb $\mathrm{CO}_{2}$ tartalom könnyebbé teszi a légvételt (Jakucs, 1959). 


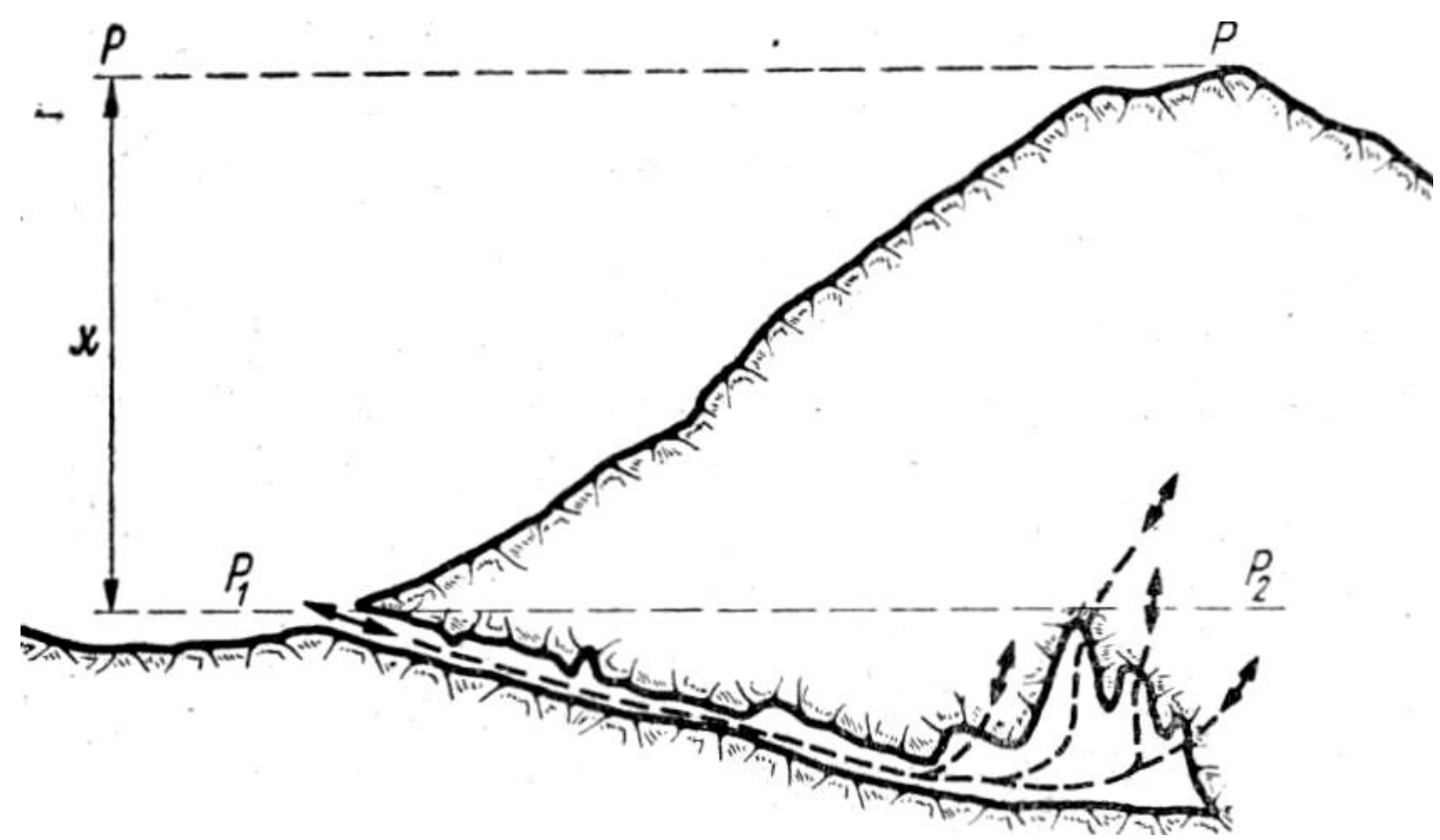

1. ábra Baradla-barlang nyomáskiegyenlítő légáramlata (Markó, Jakucs, 1956).

$P=$ légnyomás a hegy tetején, illetve azzal egy magasságban $P 1=$ légnyomás a barlang bejáratánál $P 2=$ légnyomás a hegy belsejében, a közetben levö repedésekben, a barlang bejáratával egy magasságban $x-a$ barlang bejárata és a hegy teteje közötti magasság-különbség méterben (Markó, Jakucs, 1956).

1. táblázat A barlangi klíma hatótényezői (Jakucs, 1959)

Hatótényező Hatásmód

A barlangi légtér portalansága, toxikus, izgató és egyéb

Ingerkeltés kizáródása allergénanyag-mentessége

\begin{tabular}{ll}
\hline A barlangi levegő bakteriális-virális sterilitása & Újrafertőződés lehetőségének kizáródása \\
\hline Penészgombák esetleges antibiotikum-produkciója & Antibiotikum-effektus lehetősége \\
\hline A barlangi légtér átlagosnál magasabb $\mathrm{CO}_{2}$ - tartalma & Légzésmélység fokozódása \\
\hline A $10^{\circ} \mathrm{C}$ körüli föld alatti környezet hűvössége & anyagcsere-folyamatok felgyorsulása \\
\hline A folyamatosan reprodukálódó aeroszol oldott ionjai & $\begin{array}{l}\text { Görcsoldó, gyulladás-gátló, nyákoldó, } \\
\text { fertötlenítő hatás }\end{array}$ \\
\hline
\end{tabular}

A hőmérséklet-változások hiánya

A jelentősebb légáramlások (szél) barlangi hiánya

A barlangi levegő magas relatív nedvességtartalma (80$100 \%)$;

A gyors légköri frontok, elektromos, barometrikus változások hiánya;

A karsztbarlangok megnövekedett radongáz-tartalma (alfa-sugárzása), a felszíni sugárzásokban való szegénysége, Faraday-kamra hatása

A stresszhatások kiküszöbölődése a szervezet megnyugtatása neuroendokrin szabályozás biológiai ritmus helyreállása a vegetatív idegrendszer tónusának kiegyensúlyozása

A mozgáshiányos, szokatlan föld alatti környezet, a csend, a fényszegénység, stb. lélektani hatásai 
A barlangok bejárati szakaszának klimatikus megfigyelésével egy általános csoportosítás jelenik meg (Kordos, 1970), mely szerint a bejárathoz legközelebb eső zóna a télen hülési, nyáron melegedési szakasz, a második az örvénylési szakasz, a harmadik a melegedési szakasz.

Fodor István könyvében részletesen elemzi a Baradla-, Abaligeti- Tapolcaibarlangokat, valamint a Telkibányai-, és Dobsinai-jégbarlangok klimatológiai viszonyait. A barlangok komplex barlangklimatológiai vizsgálatával kulcsfontosságú információkkal járul hozzá a barlangterápia továbbfejlesztéséhez.

\subsection{Barlangok néhány fontos klimatológiai jellemzője}

A radon gáz forrása a kőzetekben található Rádium. A szilárd halmazállapotra lehütött radon világít, mert ionizálja a levegő molekuláit. A radon a barlangi légmozgás nyomjelzője lehet, illetve segíthet a speciális mikroklíma kialakulásának jobb megértésében. Magyarországon Hackl József (Hakl, et al. 1997), Dezső Zoltán (Dezső, Molnár, 2001), Nagy Hedvig Éva (Nagy, 2012) a barlangi radon koncentrációt vizsgálta.

Egy másik nagyon fontos klimatikus jellemzője a barlangoknak a $\mathrm{CO}_{2}$.A légkör $\mathrm{CO}_{2}$ tartalma $0.039 \%$, színtelen szagtalan, nehezebb a levegőnél. Eredete: ez az egyik legáltalánosabb szervesanyag-bomlástermék. Nagy mennyiség érkezik a földkéregből különféle kísérőjelenségekkel. A talajban található mikrobák tevékenységének köszönhetően termelt gázok a karszton átszivárgó vízzel a repedéshálózaton keresztül a barlangba jutnak. Jelentős szerepük van a karsztkorrózióban és cseppkőképződésben is (Keveiné, 2009).

Magas széndioxid tartalom esetén az agy nem képes elegendő oxigént felvenni, ugyanakkor ennek elsődleges hatása a mozgásképesség elvesztése, mely gondolati szinten azonban még megvan, azonban a test csak korlátozottan képes (elesés), vagy nem képes mozogni. Az 5\% $\mathrm{CO}_{2}$ fölött a vér széndioxidtartalma növekedik, lehetőséget biztosítva a menekülésre. $8 \%$ felett azonban egy- két levegővétellel beáll a mozgásképtelenség. Bányabiztonsági szabályzat szerint $5 \%$ feletti $\mathrm{CO}_{2}$ értéknél a bányát el kell hagyni.

Müszer nélkül a következők alapján szerezhetünk tudomást a jelenlétéről: gyertya, karbidlámpa rozsdavöröses vöröses-sárgás fénnyel ég, koromcsíkot eregetve, fejfájás, légszomj, melegségérzet, túlzott izzadás, szédelgés, álmosság, gyengeségérzet, mentális problémák jelentkeznek. 
A barlangi légmozgásnak abban is nagyon sok szerep jut, hogy az emberi és állati szennyező anyagokat, vagy akár a karbid lámpa által termelt széndioxidot elszállítsa a levegőből. Normál esetben a széndioxid értéke 0,1-1\% között változhat.

2. táblázat $\mathrm{CO}_{2}$ Egészségügyi hatás (Herczeg , 2008)

\begin{tabular}{lll}
\hline $\mathbf{C O}_{\mathbf{2}} \mathbf{p p m}$ & $\mathbf{C O}_{\mathbf{2}} \mathbf{\%}$ & Egészségügyi hatás \\
\hline $350-450$ & $0,035-0,045 \%$ & természetes légköri koncentráció \\
\hline $600-800$ & $0,06-0,08 \%$ & elfogadható beltéri levegőminöség \\
\hline 1000 & $0,1 \%$ & szellőztetés szükséges \\
\hline $1000-2500$ & $0,1-0,25 \%$ & fáradtságérzet, figyelem csökkenése \\
\hline 5000 & $0,5 \%$ & $\begin{array}{l}\text { maximális megengedett munkahelyi } \\
\text { koncentráció }\end{array}$ \\
\hline 30000 & $3 \%$ & $\begin{array}{l}\text { enyhén bódító hatású, hányinger, légzés- és } \\
\text { pulzusszám-növekedés }\end{array}$ \\
\hline 38000 & $3,8 \%$ & $\begin{array}{l}\text { kilélegzett levegő } \\
\text { fejfájás és látásromlás, 1 órán át belélegezve } \\
\text { halált okozhat }\end{array}$ \\
\hline 100000 & $5 \%$ & azonnali eszméletvesztés, halál \\
\hline
\end{tabular}

Magyarországon a Alba Regiában, a Lengyel-barlangban és Cserszegtomaji-kútbarlangban tud a leggyorsabban feldúsulni a széndioxid (Gruber, 2005). Az Aggteleki Nemzeti Park Igazgatósága 2013 májusától felfüggesztette a barlanglátogatást a Béke-barlangban a kritikus szén-dioxid szint miatt (Stieber \& Leél-Őssy, 2015).

Ezekben a barlangokban 1\% és 5\% közötti értékeket mértek melyek egészségügyi hatása már nagyon káros (2. táblázat), akár légzés- és pulzusszám növekvést, fejfájást is okozhat. Akár hosszú időn keresztüli egy helyben tartózkodás esetén (pl.: feltáró munka, vagy barlangi mentés közben), rosszul szellőző szük kuszodák okozhatnak rosszullétet.

Napjainkban egyre gyarapszanak az olyan barlanghasznosítás típusok, melyek nagy tömeget vonzanak a barlangba, mely esetenként szükségessé teszi a mesterséges világítást is. A turisztika számára megnyitott barlangokban cél lenne meghatározni az optimális létszámot barlangklimatológiai szempontból. A barlangvilágítás is egy módosító tényezője a barlang hőmérsékletének (2. ábra), így az ezzel kapcsolatos vizsgálatok is nagyon fontosak.(Kaffai, Imecs, 2008).

A bejárati zónában a mérsékelt éghajlaton előfordulhat, hogy a téli befelé húzó huzat lehüti a barlang falát, és a beszivárgó víz megfagy. A tavaszi kifelé áramló levegő hatására az elolvad. Vannak olyan zsákszerü barlangok melyekben a jég felhalmozódása egész évben 
megmarad, a téli befolyó hideg levegő erősen lehűti az üregek falát, nyáron pedig a hüvös barlangi levegő nem tud a kinti melegebb levegő helyébe emelkedni.

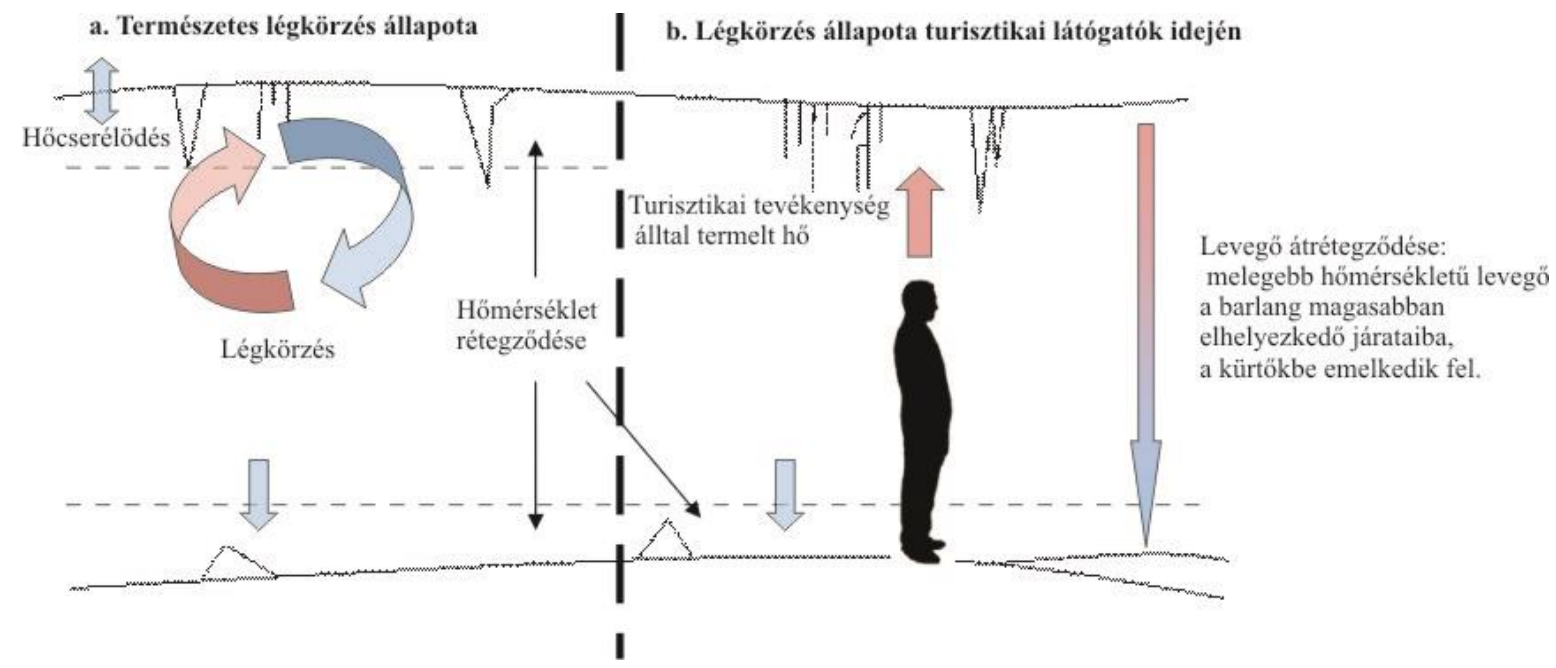

2. ábra A barlangi léghőmérséklet rétegződésének vázlatos ábrázolása (Smith et al., 2013 után módosítva)

a) A hideg levegö felgyülemlik az alapközet mentén és a természetes höáramlás nem elegendö, hogy felmelegitse a felsö légréteget. b) A turisták hötöbblete a levegö újra rétegzödését okozza, drasztikusan felmelegiti a felsöbb légrétegeket.

Az ilyen típusú jégbarlangok klímája nagyon érzékeny, bármilyen kisebb változás hatása pl.: újabb járatok megnyitása, a jégképződmények olvadásához vezet. A Dobsinaijégbarlang egy példa erre, mivel amikor a Stratenai-barlangrendszer járataival egybenyitották a megváltozott légáramlás hatására olvadni kezdett a jég. A barlangrendszerrel kapcsolatos közös járatot le kellett zárni a jég védelme érdekében.

A turisztika számára megnyitott barlangok is veszélyben lehetnek. Az 1940-ben felfedezett Lascaux-i barlang esetében különös figyelmet kell fordítani a legjelentősebb őskori rajzok védelmére, melyek a világörökség részét képzik. A barlangban a rajzok a speciális körülményeknek köszönhetően konzerválódtak a felfedezésük idejéig, mivel a kréta kori mészkőhegységben kialakult barlang fölött egy márga réteg, mely vízzáró rétegként viselkedik, ennek köszönhetően leállt a karsztosodás. A napi 1500 látogató viszont jelentősen megváltoztatta a barlang klímáját. A turisták által kilélegzett szén-dioxid miatt a falon lévő vízpárában savas kémhatás alakult ki. A másik probléma: a lámpa rendszer hő- és fény kibocsájtása kedvezett a lámpaflóra megjelenésének. A '60-as években hiába szerették volna szellőztető rendszerrel visszaállítani a barlang eredeti mikroklímáját, ez sajnos nem valósult meg, sőt egy még ellenállóbb gomba faj szaporodott 
el (Bourges, et al., 2014). 2002 óta senki nem léphette át a barlang bejáratát, csak a két fős speciális csoport, akik a gombák eltávolításáról gondoskodnak (Lascaux, 2015).

\subsection{A barlangok morfológiai sajátosságai}

Egyes barlangok morfológiai sajátosságuk miatt rosszul szellőznek, itt egy barlangtúra vagy barlangkutatás alkalmával akár annyira megemelkedhet a szén-dioxid szint, hogy veszélyessé válhat a barlangban tartózkodás. Rendkívül változatos alakú barlangok alakultak ki, most néhány csoportosítási lehetőséget mutatok be.

A barlang alakjának jellemzői és a járatok formakincse a járatrendszer kialakulásáról árul el sok mindent. A járatok egymáshoz viszonyított alaprajzi helyzete sokban függ a barlangot kialakító tényezőktől. A különböző alakú, és különböző nagyságú járatszelvényeken a levegő áramlása akadályokba ütközhet.

Lehetnek jól szellőző, és rosszul szellőző járatok, melyek tulajdonsága függ a következőktől:

- a bejárat hol helyezkedik el a felszínen,

- hány bejárata van a barlangnak,

- a járatok bejárattól vett távolságától és a szintkülönbségtől,

- a járatok irányától,

- járatok keresztmetszetétől,

- járatok tengerszint feletti magasságától.

A barlangrendszerek alakjára vonatkozó néhány jellemző példa. A hideg vizes, patakos járatok alakja nagyon hasonlít a felszíni folyóhálózathoz, fóág- mellékág kapcsolata a járatoknál is megfigyelhető (3. ábra). A patakos barlangok talpszintje a felszínről származó hordalék feltöltő hatása miatt közel egyenletes lejtésű a víznyelőtől a forrásig.

A hévizes eredetű barlangok esetén hasadékokból kialakult, hálózatos járatrendszer figyelhető meg, melynél egyenrangú ágak jellemzőek (3. ábra). A több szintes, egymás fölött elhelyezkedő járatrendszerek kialakulásában két fó tényező hatott: a hegységek kiemelkedése, és ennek következtében a karsztvízszint szakaszos változása, ezt a folyamatot az éghajlat-ingadozás segítette elö.(Kraus, 2000).

Az anasztomizáló alak esetén jól elkülöníthető a barlang aktív fóága, és az időszakosan aktív mellékág (3. ábra). 
Hipogénkarszt járatok nem egy törésvonal mentén alakulnak ki, szabálytalan ágasbogas járatrendszer jellemzi, keveredési korrózió hatására kialakult gömbüstök tagolják, ezt ún. szivacsos szerkezetnek nevezik (3. ábra). A feláramló víz hatására nagy terek, széles járatok jönnek létre (Fairchild, Baker, 2012).

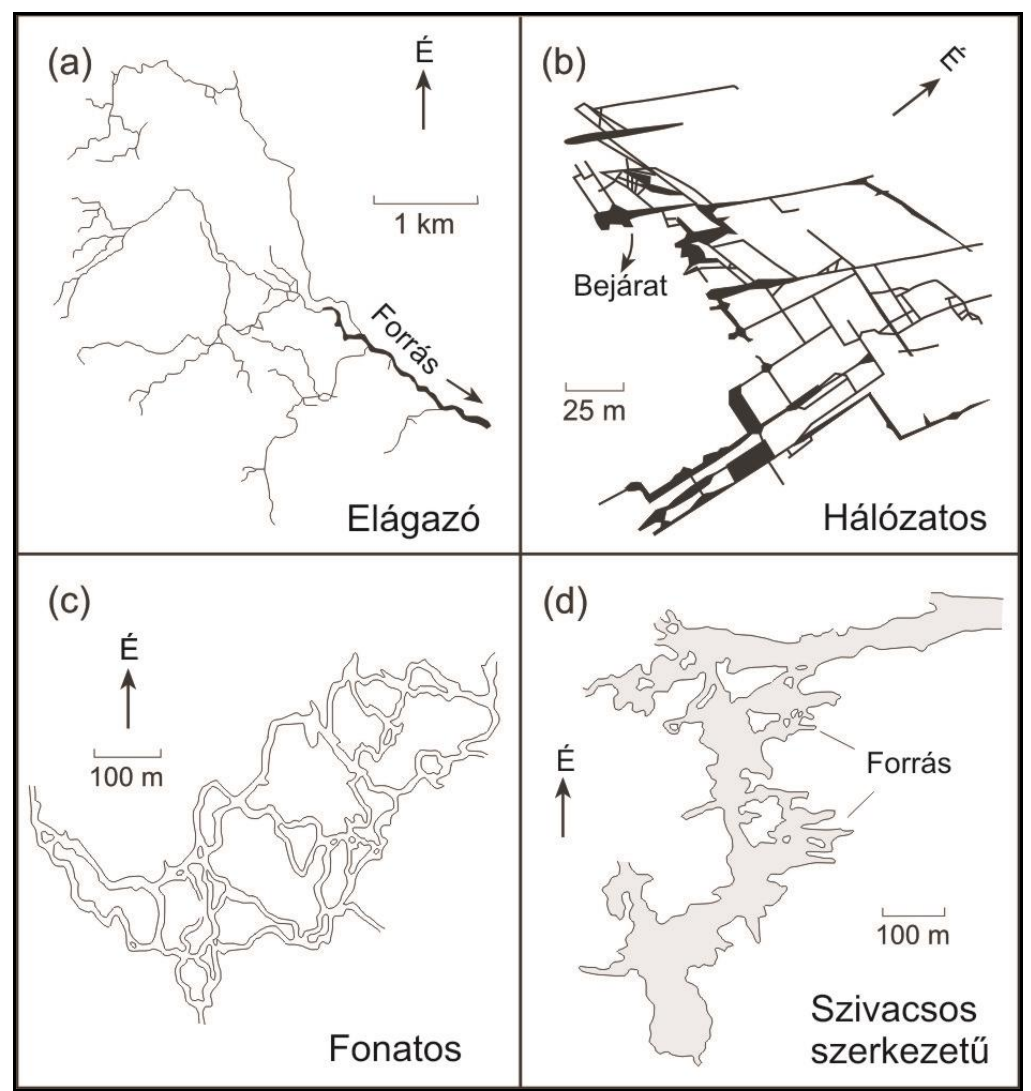

3. ábra Barlangrendszerek jellemző járatalakzatai

a)Patakos:Crevice-barlang, Missouri, b) Hálózatos: Crossroads-barlang, Viriginia, c) Anasztomizáló: Hölloch, Svájc, d)Hipogén eredetü: Carlsbad-barlang, Új-Mexikó (Fairchild, Baker, 2012 után módositva)

A barlangokat kialakító különböző hatások alapján is csoportosíthatjuk a különböző járat típusokat. Az anasztomizáló járatok esetében (4. ábra) horizontálisan történő lassú oldás jelzi a barlangi patak útját.

A freatikus járatok keresztszelvénye (4. ábra) a különböző rétegek oldhatósága alapján fog kialakulni, színlők alakulnak ki.

A freatikus járatokra ovális alak jellemző (4. ábra).

A cikk-cakk alakú járatok esetében a freatikus zónában található víz ciklikus mozgásával alakulnak ki (4. ábra). Abban az esetben, ha egy járat teljesen kitöltődik 
üledékkel, a víz egy magasabb szinten újabb hasonló morfológiájú járatokat alakít ki, azaz szifonkerülő alakul ki.

(a)

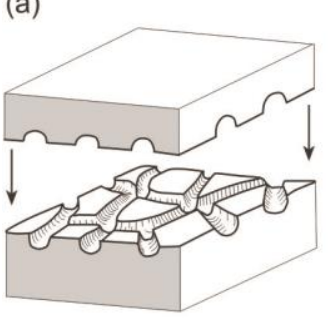

(b)

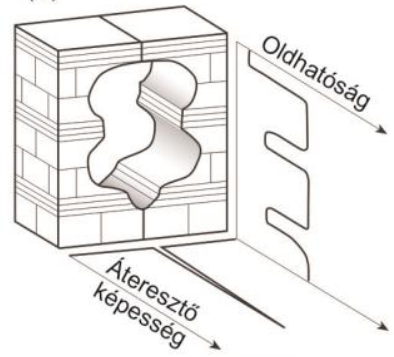

(e)

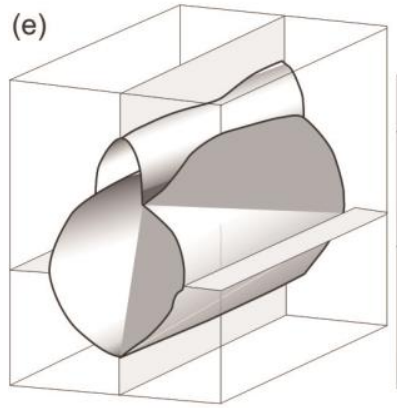

(f)

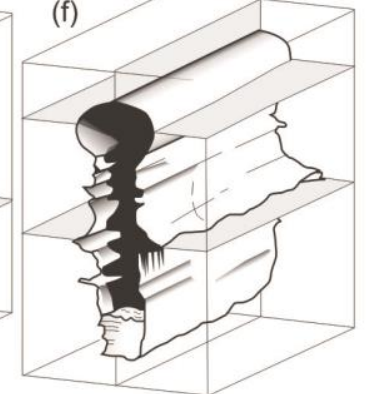

(c)

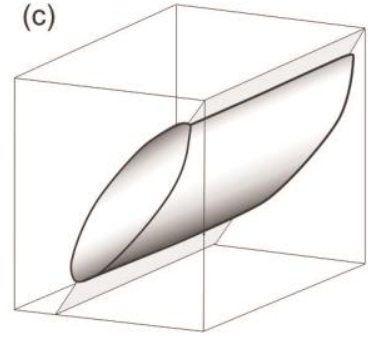

(g)

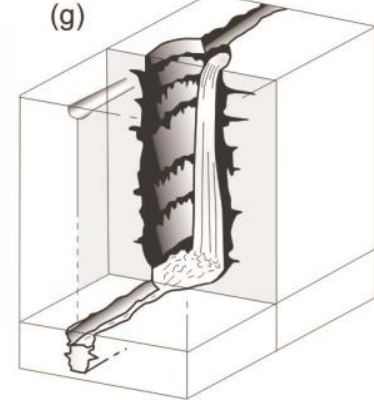

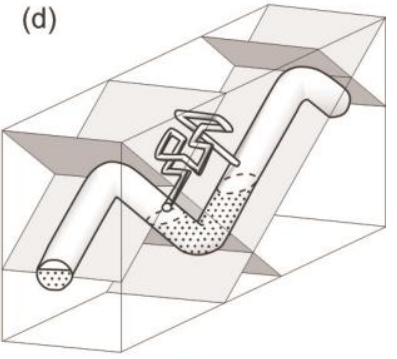

(h)

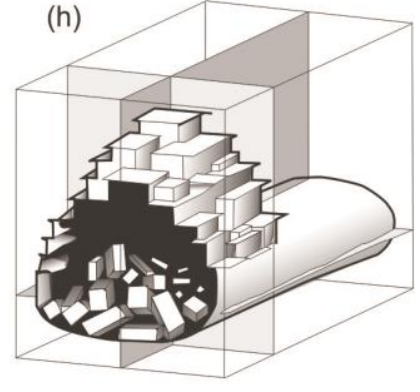

4. ábra Barlang morfológiai genetikai variációk (Fairchild, Baker, 2012 után módosítva)

Freatikus járaton belül a mennyezeten, a keveredési korrózió, vagy törés mentén oldódással egy újabb járat vagy boltív jön létre (4. ábra).

A kulcslyuk alakú járatok kezdeti freatikus járatból mélységi lefejeződéssel bevágódnak. A vadózus kanyonnak a szélessége, és tagoltsága függ a járat falának oldhatóságától (4. ábra).

A vadózus járatok esetén, ha vízesés erodálja a járat falát, akkor erősen tagolt oldalfal jöhet létre a különböző rétegek oldása miatt (4. ábra).

Repedések találkozásánál a járat főtéje beomolhat, így jön létre a felboltozódás (4. ábra) (Lauritzen, Lundberg, 2000).

A járatok keresztmetszetének alakja alapján is csoportosíthatjuk az egyes barlangszakaszokat. Az üregek alakját ebben az esetben is a kőzet különböző oldékonyságú részei határozzák meg. A járatokat keresztmetszetük alapján csoportosíthatjuk az összetettség, szélesség, magasság és szélesség, szintek, fő kiterjedése, és szimmetria alapján (5. ábra) (Kraus, 2000).

A vízáramlások különböző mértéke is különböző oldásformákat eredményezhet. A hazai nagybarlangok többsége vastagpados triász mészkőben alakult ki, melyen nem 
található fedőréteg, így a keresztmetszetet csak elhanyagolható mértékben módosítja a víz erodáló hatása.. A bakonyi barlangok esetében, ahol löszös fedőüledék található, a jura és kréta mészköves területek, a falfelület erős tagoltsága megfigyelhető, az időszakosan bemosódó löszös üledék miatt (Kraus, 2000).

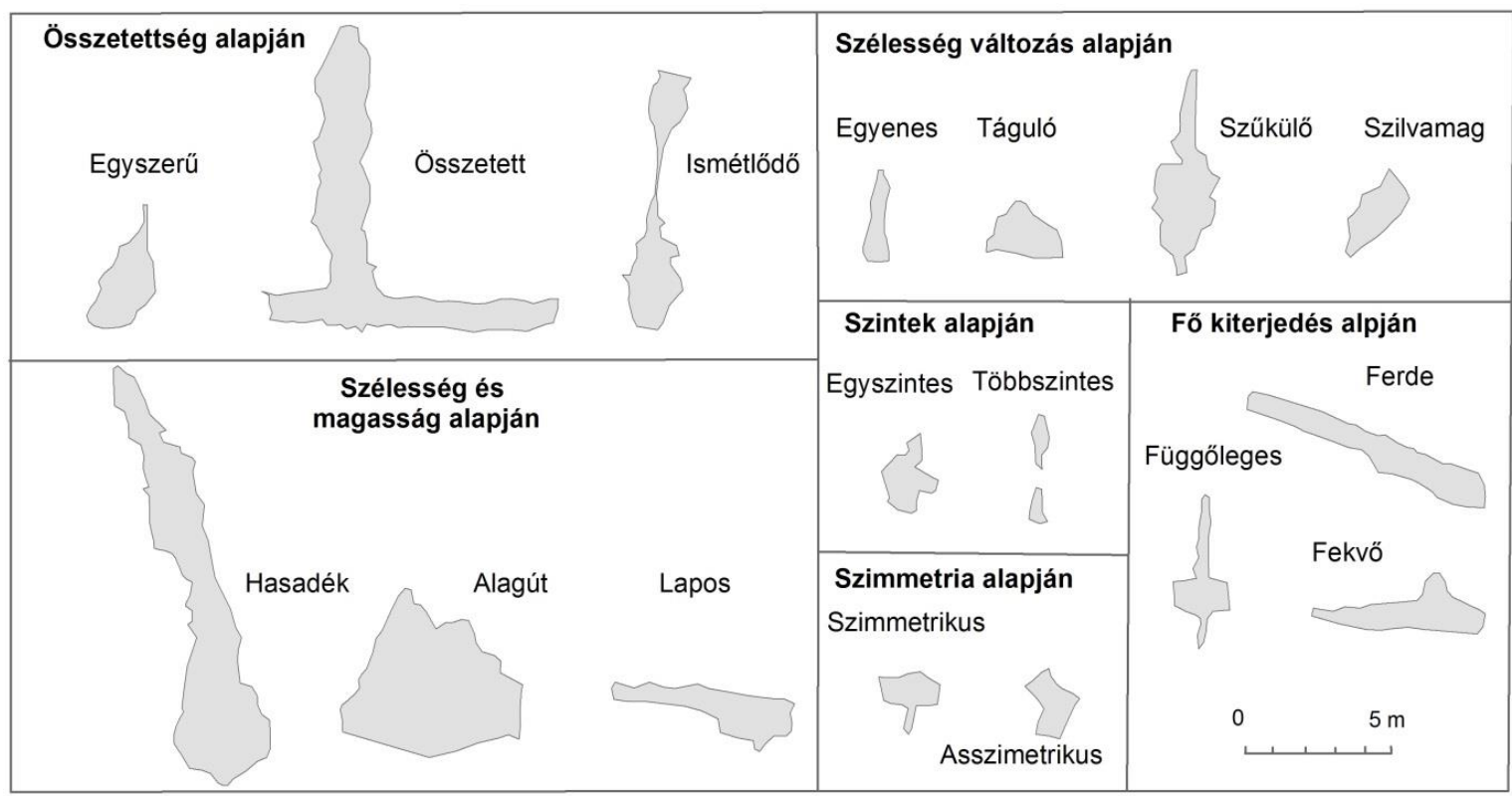

5. ábra A járatok jellegének csoportosítása (Börcsök, 2000 után módosítva)

Az éghajlat változása során a szárazabb időszakban szükebb járatszelvény alakul ki, míg, amikor több a csapadék, az árhullámok kialakulásához vezethet, mely hatásra a barlangi patak nagyobb hordalékmennyisége fokozza a koptató hatást. A patak meanderező jellege miatt szélesebb járat alakul ki. A periodikus vízhozam változás egymás fölött több szintben futó színlőket eredményezhet.

Színlök akkor is kialakulhatnak, ha különböző kőzettani adottságai vannak a járatnak, így a kevésbé oldható, vagy egy keményebb kőzet kipreparálódhat (Jakucs, 1971).

\subsection{A barlangi légáramlás fizikai mozgatórugója}

A barlangi légáramlás vizsgálata talán a legfontosabb a feltáró kutatások szempontjából, hiszen már régóta ismert, hogy a huzat mutatja a legjobban a továbbjutás útját. A barlangi légáramlás alapvető oka a felszíni levegő és a barlangi hőmérséklet különbsége. A talaj és a kőzet puffer hatása miatt a felszínen bekövetkező hőmérsékletingadozás (kőzettől függően) már 5-30 méteres vertikális távolságon belül $0,01{ }^{\circ} \mathrm{C}$-ra csökken. A barlangok ennél jelentősen mélyebben találhatók, így a barlangok mélységében a kőzetben már nincs 
hőingadozás. A barlang és a felszín közötti légcsere következményeképp mérhetünk hőmérsékletingadozást a barlangban (Rajczy, 2000).

A barlangokban megtalálható légnemü kitöltés viselkedése a légáramlás törvényszerüségei által válik érthetővé. A barlangklímát befolyásolja a befogadó kőzet közel állandó hőmérséklete, a felszíni időjárás változékonysága,de a csepegő víz és patak hatása sem elhanyagolható.

Többféle légáramlás típust különböztetünk meg. A 3. táblázat összefoglalja a barlangi légáramlás fizikai okait, és bemutatja a légcsere nagyságát különböző időszakokban és különböző körülmények között (3. táblázat). A megkülönbözetett huzat fajták természetesen nem külön-külön müködnek.

A barlangi légmozgást a felszíni és a barlangi levegő nyomáskiegyenlítődése indukálja. A barlangi légmozgást leíró egyenlet:

$$
P U A=V \frac{\Delta P}{\Delta t}
$$

ahol,

$\mathrm{P}$ - légnyomás

U - légáramlás erőssége egy adott keresztmetszetten

A -járat felület egy adott keresztmetszetten

$\mathrm{V}$ - mérési szakasz térfogata

A termikus, azaz konvektív légáramlást a levegőoszlop átlagos hőmérséklete vezérli. Nyáron, a felszíni meleg, könnyebb a levegő a barlang belsejében túlnyomást okoz, így a barlangból kiáramló levegő figyelhető meg. Télen a huzat iránya megfordul, a termikus huzat esetén jellegzetes napi járás, és évszakos menet figyelhető meg (Gádoros, 2000).

$$
U=k \sqrt{\left[g h\left(\frac{\Delta \rho}{\rho}\right)\right]}
$$

ahol,

U - légáramlás sebessége

k - konstans, ami inverz módon függ a Reynolds számtól

g - gravitációs állandó

h - járat magasság

$\Delta \rho$ - áramló és nem áramló levegő sürüség különbsége 
$\rho$ - levegő sürüsége?

A szél okozta huzat nehezen kiismerhető, mivel ez függ a szél erősségétől és irányától is. A légnyomás kiegyenlítő huzat esetén, ha a felszínen változik a légnyomás, akkor a barlangban is változnia kell (Gádoros, 2000).

$$
P_{\text {wind }}=0.5 \rho U^{2}
$$

ahol,

$\mathrm{P}_{\text {wind- }}$ szél indukálta nyomásváltozás

$\rho$ - levegő sürüsége (mely függ a hőmérséklettől, páratartalomtól, és tengerszintfeletti magasságtól)

U - légáramlás sebessége

A klasszikus kéményhatás pl. a kürtőkben figyelhető meg: a melegebb, ritkább levegő, és a hidegebb, sűrübb levegő fajsúlykülönbsége okozza a légáramlást (Losonci, 2014).

$$
\begin{aligned}
& Q=K * A \sqrt{2 g * \Delta h * \frac{T_{i}-T_{0}}{T_{i}}}, \text { ha } T_{i}>T_{0} \\
& Q=K * A \sqrt{2 g * \Delta h * \frac{T_{0}-T_{i}}{T_{0}}}, \text { h } a T_{0}>T_{i}
\end{aligned}
$$

ahol,

$\mathrm{Q}$ - légáramlás

K - Felszíni légnyomás együtthatója (értéke ált. 0,65)

A - bejárat felülete $\left(\mathrm{m}^{3}\right)$

$\Delta \mathrm{h}-\mathrm{a}$ rendszer magassága $(\mathrm{m})$

$\mathrm{T}_{\mathrm{i}}-$ belső barlangi léghőmérséklet $(\mathrm{K})\left(\mathrm{K}={ }^{\circ} \mathrm{C}+273,15\right)$

$\mathrm{T}_{0}$ - felszíni léghőmérséklet $(\mathrm{K})$

Huzat nagysága arányos:

- járatszelvénnyel

- kinti és a barlangi levegő hőmérsékletének négyzetgyökével

- bejáratok szintkülönbségének négyzetgyökével (Losonci, 2014)

A különböző barlangi légmozgásokra néhány példa (Losonci, 2014):

- 2014.01.03. Hölloch (Svájc $120 \mathrm{~km},-940 \mathrm{~m}$ ) U = $15 \mathrm{~m}^{3} / \mathrm{s}$

- 2014.02.20. La Diau (Franciaország $20 \mathrm{~km},-700 \mathrm{~m}$ ) U $=11 \mathrm{~m}^{3} / \mathrm{s}$ 
3. táblázat A levegőmozgások összesítése a fizikai törvények alapján a barlangban és a körülötte lévő karsztos kőzeten (Fairchild, Baker, 2012).

\begin{tabular}{|c|c|c|c|c|}
\hline Jelenség & Fizikai ok & $\begin{array}{l}\text { Változás } \\
\text { mértéke }\end{array}$ & $\begin{array}{l}\text { Előfordulási } \\
\text { hely }\end{array}$ & Időtartama \\
\hline $\begin{array}{l}\text { Barlang } \\
\text { légmozgás } \\
\text { Napi vagy } \\
\text { szinoptikus } \\
\text { légköri } \\
\text { nyomásváltozás } \\
\text { (vagy zavaró } \\
\text { antropogén } \\
\text { tényező pl. } \\
\text { ajtókinyitás) }\end{array}$ & $\begin{array}{l}\text { Nyomás- } \\
\text { kiegyenlítődés }\end{array}$ & $\begin{array}{l}\text { Akár több tíz } \\
\text { millibar (azaz } \\
\text { ezer pascal), de } \\
\text { erősen függ az } \\
\text { aránya a bejárat } \\
\text { keresztmetszet } \\
\text { szelvényétól, és a } \\
\text { barlang méretétől }\end{array}$ & $\begin{array}{l}\text { Erős } \\
\text { nyomásváltozás } \\
\text { Közel a } \\
\text { bejárathoz, ahol } \\
\text { bejárat, és a } \\
\text { barlang méretének } \\
\text { aránya nagy. }\end{array}$ & $\begin{array}{l}\text { Jellemzően } \\
\text { óráktól napokig. }\end{array}$ \\
\hline $\begin{array}{l}\text { Szél okozta } \\
\text { légáramlat, } \\
\text { Nagy } \\
\text { szélsebesség }\end{array}$ & $\begin{array}{l}\text { Fölerősödik a szél } \\
\text { a barlangban, } \\
\text { vagy szívó hatás } \\
\text { lép fel, amikor a } \\
\text { keresztülfúj a } \\
\text { nyílásnál } \\
\text { (Venturi-hatás) }\end{array}$ & $\begin{array}{l}\text { 60Pa változás } \\
\text { indukál } 10 \mathrm{~m} / \mathrm{s} \\
\text { légáramlatot, míg } \\
\text { a 15Pa nyomás } \\
5 \mathrm{~m} / \mathrm{s} \text {-ot. }\end{array}$ & $\begin{array}{l}\text { A barlang bejárat } \\
\text { szöget zár be a } \\
\text { széliránnyal } \\
\text { Venturi-hatás lép } \\
\text { fel, ha a szél } \\
\text { keresztülfúj a } \\
\text { bejáraton. }\end{array}$ & $\begin{array}{l}\text { Jellemzően } \\
\text { óráktól napokig } \\
\text { (lehet napi menete } \\
\text { is) }\end{array}$ \\
\hline $\begin{array}{l}\text { Kürtők } \\
\text { légkörzése, vagy } \\
\text { kémény-hatás } \\
\text { Folyamatos hülés } \\
\text { (téli/nyári) }\end{array}$ & $\begin{array}{l}\text { Hosszan tartó } \\
\text { különbség a } \\
\text { barlangi és a } \\
\text { felszíni levegő } \\
\text { fajsúlyában.. }\end{array}$ & $\begin{array}{l}\text { Ha két bejárat } \\
\text { közötti magasság } \\
\text { különbség } 100 \mathrm{~m} \text {, } \\
\text { akkor a } \\
\text { nyomáskülönbség } \\
44 \mathrm{~Pa} /{ }^{\circ} \mathrm{C} \text {. A } \\
\text { mélyülö } \\
\text { barlangok } \\
\text { esetében, az } \\
\text { áramlást télen a } \\
\text { gravitáció erősíti. }\end{array}$ & $\begin{array}{l}\text { Legalább } 2 \text { nyitott } \\
\text { vagy szellőző } \\
\text { bejárat esetében, } \\
\text { különböző } \\
\text { magasságokban }\end{array}$ & Szezonális. \\
\hline $\begin{array}{l}\text { Konvekció, } \\
\text { A külső vagy } \\
\text { belső levegő } \\
\text { hülése vagy } \\
\text { melegedése a } \\
\text { barlang } \\
\text { különböző } \\
\text { szakaszaival } \\
\text { összehasonlítva }\end{array}$ & $\begin{array}{l}\text { a) Kényszerített } \\
\text { höáramlás, } \\
\text { különbözö } \\
\text { hőmérsékletủ } \\
\text { légtömegek } \\
\text { hőátadása miatt } \\
\text { kialakuló áramlás. } \\
\text { b) Szabad } \\
\text { (termális) } \\
\text { hőáramlás }\end{array}$ & $\begin{array}{l}\text { A sebesség } \\
\text { arányos a } \\
\text { nyomáskülönbség } \\
\text { négyzetével és az } \\
\text { áramlás helyének } \\
\text { magasság } \\
\text { különbségével. }\end{array}$ & $\begin{array}{l}\text { a) Alászálló } \\
\text { barlang a hideg } \\
\text { levegő áramlik a } \\
\text { járatok talpa felé. } \\
\text { Emelkedő meleg } \\
\text { levegő feláramlik } \\
\text { a járat teje felé. } \\
\text { b) Magas széles } \\
\text { termekkel tagolt } \\
\text { barlangok } \\
\text { esetében }\end{array}$ & $\begin{array}{l}\text { Változó a rövid } \\
\text { távútól (óra vagy } \\
\text { napi) egészen a } \\
\text { szezonálisig. }\end{array}$ \\
\hline $\begin{array}{l}\text { Víz indukálta } \\
\text { áramlás }\end{array}$ & $\begin{array}{l}\text { a) Barlang patak } \\
\text { okozta légáramlás } \\
\text { b) Víz indukálta a } \\
\text { repedésekben } \\
\text { kétfázisú (víz- } \\
\text { levegö) }\end{array}$ & $\begin{array}{l}\text { Lokális } \\
\text { előfordulás }\end{array}$ & $\begin{array}{l}\text { a) Alászálló } \\
\text { barlang járatok } \\
\text { b) Légáramlás } \\
\text { kétfázisú (víz- } \\
\text { levegö)repedésren } \\
\text { dszerben } \\
\end{array}$ & $\begin{array}{l}\text { Eseményen } \\
\text { alapuló, } \\
\text { évszakhoz kötött, } \\
\text { és egész éven át } \\
\text { tartó is lehet. }\end{array}$ \\
\hline
\end{tabular}

A Beufort-fokozat alapján érzékletesebbé válhat, hogy az egyes légáramlások a felszínen milyen hatással vannak környezetükre (4. táblázat). 
4. táblázat Beaufort-fokozat (https://www.met.hu/ismertetok/Beaufort-skala.pdf)

\begin{tabular}{|c|c|c|c|}
\hline $\begin{array}{l}\text { Beaufort- } \\
\text { fokozat }\end{array}$ & $\begin{array}{l}\text { Szélsebesség } \\
\mathrm{m} / \mathrm{s}\end{array}$ & Meghatározás & Hatása \\
\hline 1 & $0-0,3$ & Szélcsend & A füst egyenesen száll felfelé. \\
\hline 2 & $0,4-1,7$ & $\begin{array}{l}\text { Gyenge szellö, } \\
\text { fuvallat }\end{array}$ & $\begin{array}{l}\text { A felszálló füst gyengén ingadozik, a szél alig } \\
\text { érzékelhető }\end{array}$ \\
\hline 3 & $1,8-3,1$ & Enyhe szél & $\begin{array}{l}\text { A fák levelei zizegnek, arcon érezhető } \\
\text { légmozgás }\end{array}$ \\
\hline 4 & $3,2-5,3$ & Gyenge szél & A szél a fák leveleit, vékony hajtásait mozgatja. \\
\hline 5 & $5,4-8,1$ & Mérsékelt szél & $\begin{array}{l}\text { A szél a fák gallyait, kisebb ágait állandóan } \\
\text { mozgatja. }\end{array}$ \\
\hline 6 & $8,2-10,9$ & Élénk szél & $\begin{array}{l}\text { A nagyobb faágak is mozognak, a levegő } \\
\text { mozgása jól hallható. }\end{array}$ \\
\hline 7 & $11,0-13,7$ & Erős szél & $\begin{array}{l}\text { Már a legvastagabb ágakat is mozgatja, a } \\
\text { villanyvezetékek zúgnak. }\end{array}$ \\
\hline 8 & $13,8-16,9$ & Viharos szél & $\begin{array}{l}\text { A kisebb fák törzsei erősen hajladoznak, } \\
\text { vékonyabb gallyak letörnek. A széllel szemben } \\
\text { nehéz a gyaloglás. }\end{array}$ \\
\hline
\end{tabular}

A különböző jelenségeket más-más fizikai hatás váltotta ki, és más-más időtartammal játszódnak le, így ezeket különböző diagramokkal tudjuk leírni. Rendszer változásának típusai az idő függvényében (6. ábra): Az a)-d) és az f) diagram a rendszer változásait mutatja be. Az 6.a ábra azt a kontrasztot mutatja be mely során egy változás jön létre egy kényszerítő hatás miatt, így a rendszer egyre közelebb kerül a küszöb értékhez, majd egy ponton túl tovább mozdul hirtelen egy másik állapotba.

A 6.b ábra esetében a napi hőingás oszcilláló mozgását írja le a függvény, melyből meg lehet állapítani a napi minimum és maximum értékeket, a hőmérséklet-változás mértékét. A barlangon belül is megfigyelhetők ilyen jelenségek, csak ott kisebb mértékü változás jelentkezik.

A 6.c ábra az éves hőingás és légnyomás értékek megjelenítésekor jellemző.

A 6.d ábra alapján meghatározható, hogy mennyi idő alatt, mekkora hőmérsékletváltozást okozott akár egy csoport a barlangban, és ennek mennyi a lecsengési ideje. 


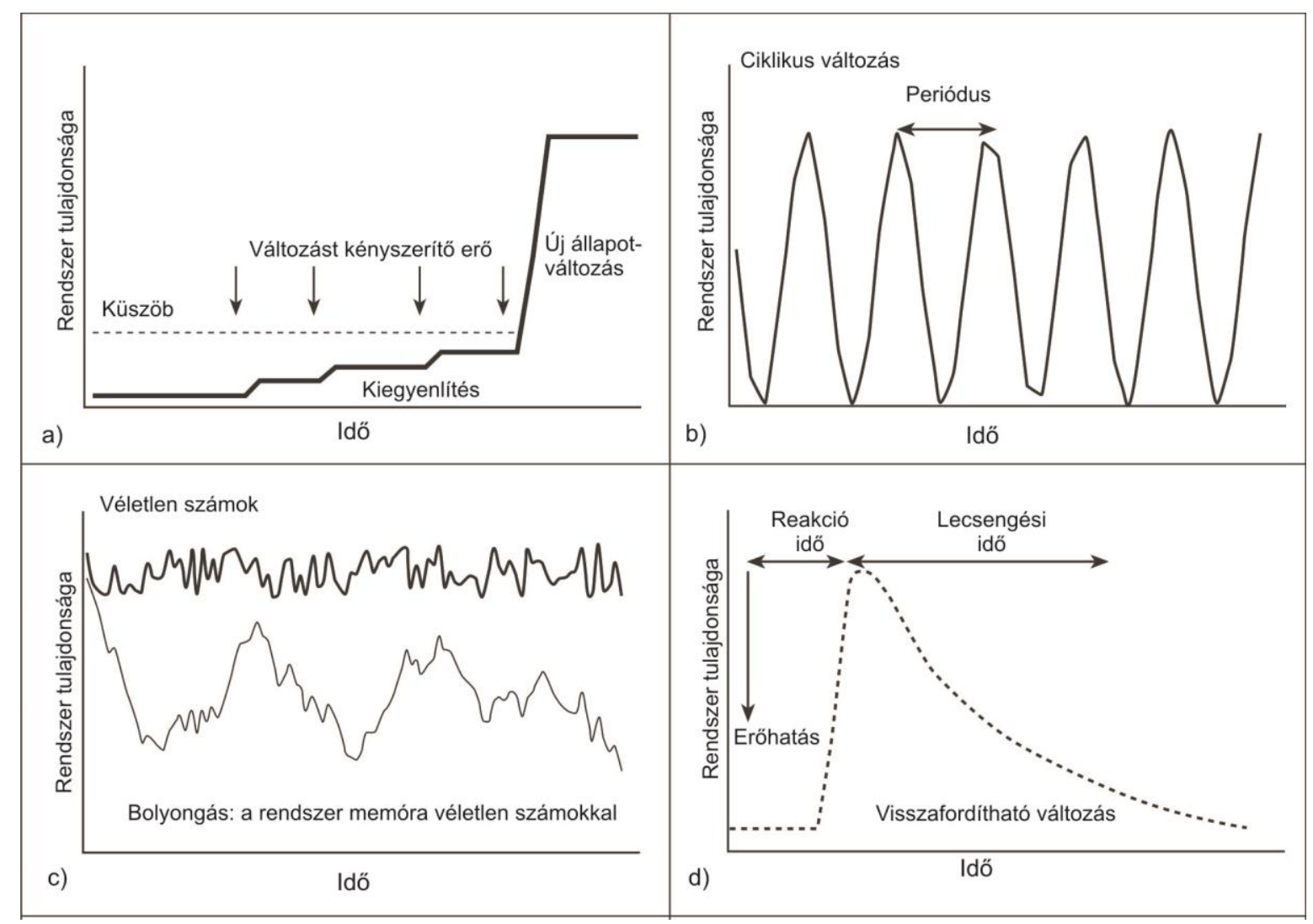

6. ábra Rendszer változásának típusai az idő függvényében (Fairchild, Baker, 2012 után módosítva)

a) hirtelen változást kiváltó-szél okozta légáramlat, b) periodikus hömérséklet-változás napi höingás, c) véletlenszerü-éves menet, d) visszafordítható változás - antropogén hatás, ajtónyitás

\subsection{Barlangok geometriájának köszönthető módosított légáramlás}

Néhány példán keresztül szemléltethetők a barlangalakzatok különböző hatásai a légáramlatra. Az első esetben a bejárat geometriája kedvez az erős légáramlat kialakulásának (7.a ábra), míg a második esetben a barlang bejárata kedvez a szél okozta légáramlat kialakulásának (7.b ábra).

Kémény-hatás a Glowworm Cave, Új-Zélandon (de Freitas, et al., 1982), mely mutatja szezonálisan uralkodó légáramlást a 24 órás időtartamú detektált adatokból, nyáron a lefelé irányuló légáramlat az uralkodó, mely a téli hónapokban megfordul és a felfelé irányuló levegő lesz a domináns. Ebben az esetben a bejáratok nyílása között $14 \mathrm{~m}$ a magasság különbség (7.c ábra). 
(a)

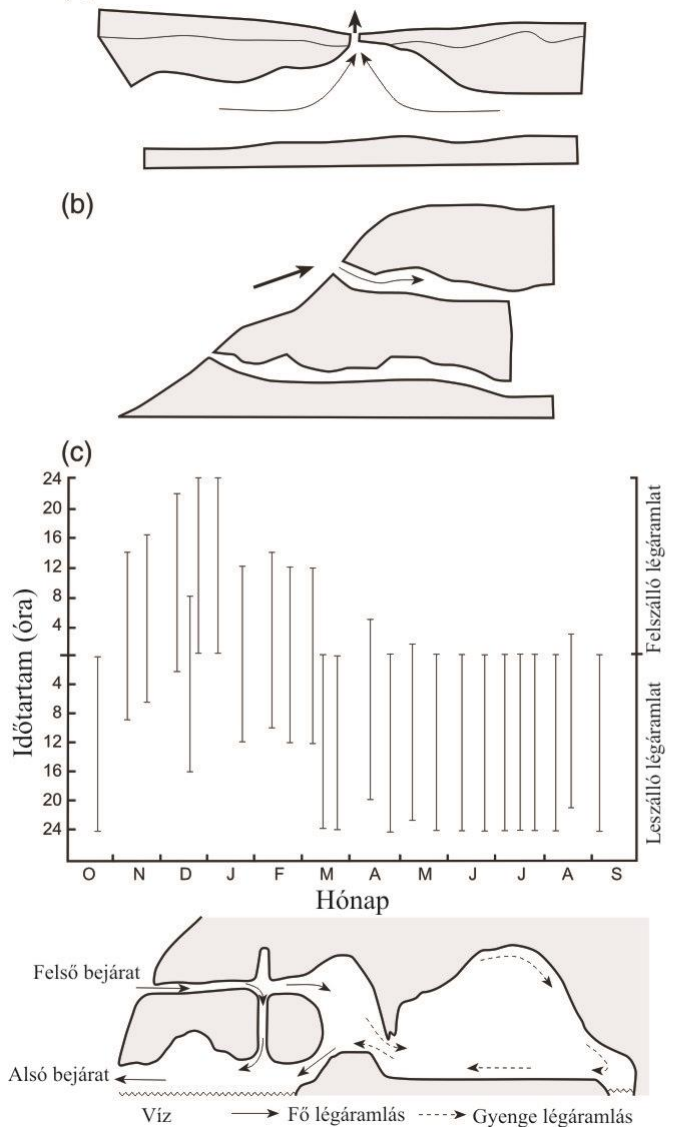

(d)
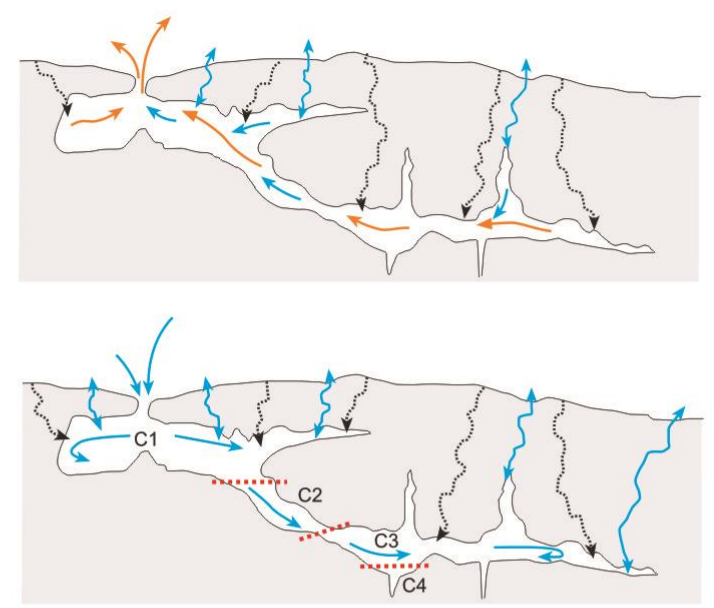

(e)

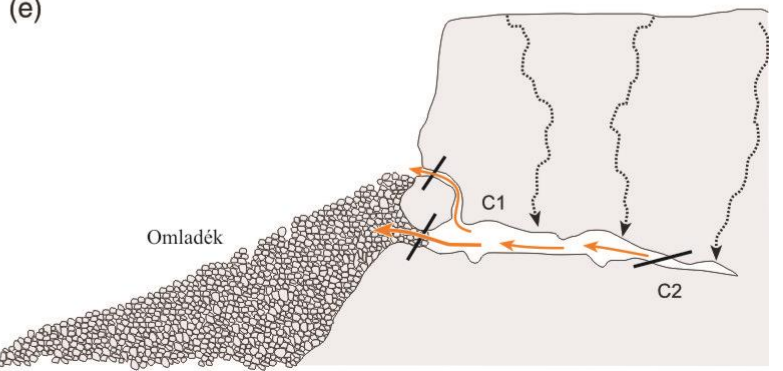

7. ábra A légáramlás sematikus vázlatai különböző barlangrendszerekben (Fairchild, Baker, 2012 után módosítva)

A konvekciós áramlás esetén a nyári légkörzésnél a felszíni meleg levegő a kőzetrepedéseken át hőátadással módosítja a barlangi levegőt, amely így melegszik és melegebb levegő feláramlik (narancssárga nyíl), így kiszorítván a hidegebb levegőt.

Téli légkörzés esetén, a beáramló hideg levegő (kék nyíl) indukálja a légáramlást és az áramlás mértéke a bejárattól távolodva ( $\mathrm{C} 1-\mathrm{C} 4)$ egyre gyengébben hat (7.d ábra) (Bourges, et al., 2001; Bourgas, et al., 2006a).

Epikarsztos modell (pl. az üreg típusú Chauvet-barlang aerodinamikai müködése). A karszt beszivárgási zónájában a kőzet repedésein beáramló levegő és víz egyirányú légáramlást generál. A végpont és a $\mathrm{C} 2$ között a $\mathrm{CO}_{2}$ magasabb, ezen a szakaszon a légáramlás is elhanyagolható (7.e ábra) (Bourges, et al., 2006b)

A több bejáratú barlangok esetén a légáramlás iránya nagyban függ attól, hogy a bejáratok közötti járatok mennyire jól tudnak szellőzni. A példa ábrán (8. ábra) is jól látható, amikor a 4 bejáratú barlang (E1-E4) környezetében hidegebb beáramló levegő található az alsó három bejáraton (E1-E3), míg a legfelső bejáraton át (E4) távozik a 
levegő a barlangból. Abban az esetben, amikor a felszíni levegő melegebb, mint a barlangi a felső három bejáraton keresztül (E2-E4) húz be a légáram, míg az alsón (E1) kiáramlik.

Ha a barlangjáratokon belül szükület található (9. ábra) esetünkben a E2-E3 bejáratot összekötő folyosón, az úgy módosítja a légáramlást, mintha két külön rendszerről lenne szó.

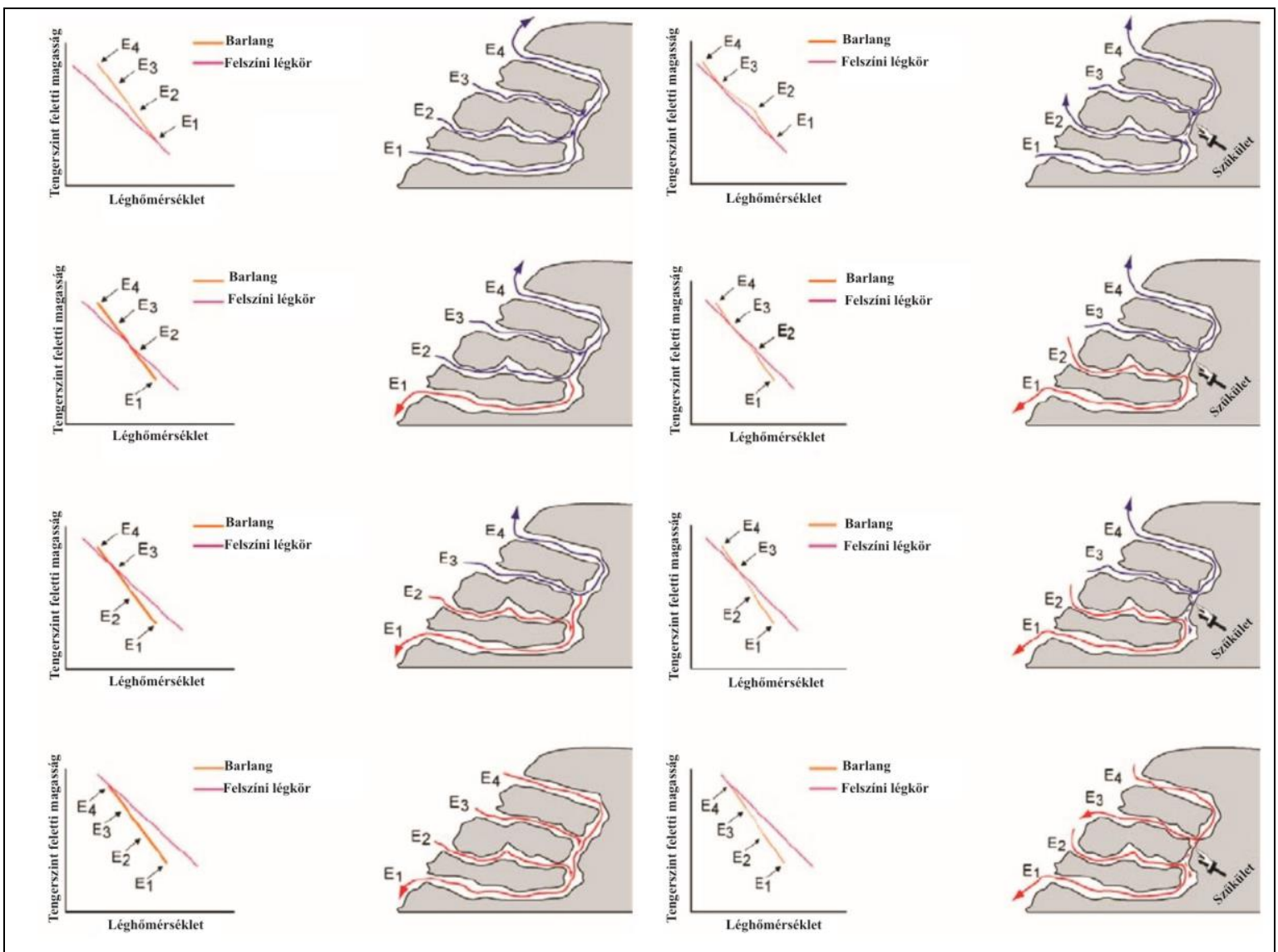

8. ábra Sematikus ábra a több bejáratú, szükület 9. ábra Sematikus ábra a több bejáratú, nélküli barlangrendszer légáramlásáról a szükülettel rendelkező barlangrendszer léghőmérséklet és a tengerszint feletti magasság légáramlásáról a léghőmérséklet és a tengerszint függvényében (Filliponi, 2003 után módosítva). feletti magasság függvényében (Filliponi, 2003 után módosítva) 


\section{Mintaterület bemutatás}

\subsection{A barlangokat befogadó hegységek bemutatása}

\subsubsection{Bükk}

Magyarország legmagasabban elhelyezkedő (600-900 m) és legnagyobb kiterjedésű $\left(120 \mathrm{~km}^{2}\right)$ karsztvidéke. A legnagyobb kiterjedésben jól karsztosodó triász-jura mészkőből áll (Hevesi, 1991). A terület másik jelentős felszínalkotó kőzete az idősebb agyagpala. A mészkő és az agyagpala a kréta tektonizmus hatására jelentősen meggyürödött, illetve az idősebb agyagpala a fiatalabb mészkőre tolódott (10. ábra) (Hevesi, 1978). Az ausztriai hegységképző mozgások hatására jelentős deformációs események történtek (gyürődés, takaró képződés, töréses deformáció), majd a terület a paleogénre a szárazföldi lepusztulás térszíne lett, melyet jól alátámasztanak a barlangi üledékek geokémiai vizsgálatai (Mucsi, 1992). A terület negyedidőszaki fejlődéstörténete kevéssé ismert, ugyanakkor kijelenthető, hogy a felső eocén- alsó oligocén között a terület hosszabb ideig volt a szárazföldi lepusztulás, mint a tengeri üledék felhalmozódás színtere.

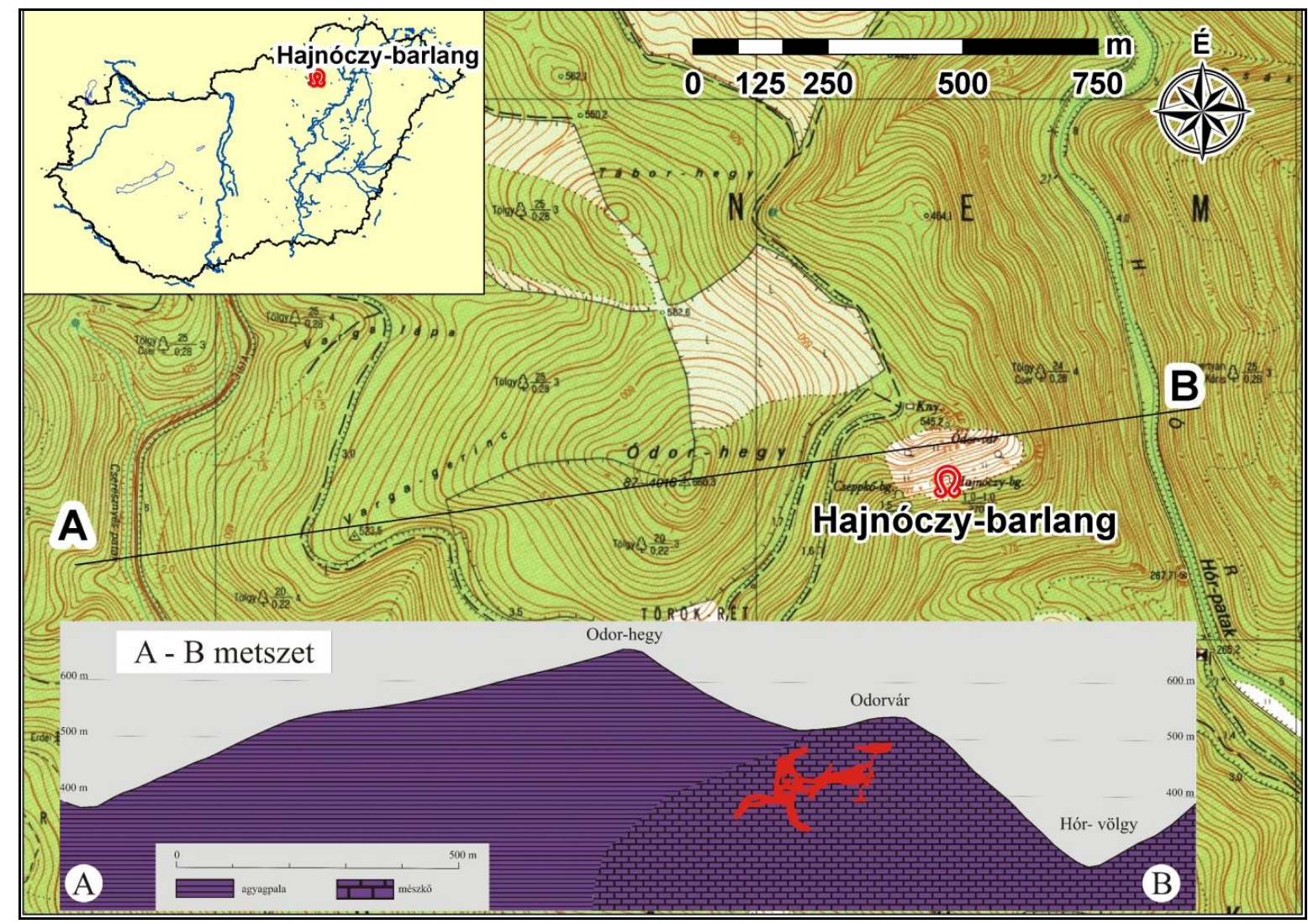

10. ábra Odorvár és az Odor-hegy geológiai felépítése, és a Hajnóczy-barlang keresztmetszete (NyDNy-KÉK irányú metszet) Szerkesztette: Muladi B., Mucsi L. Varga Cs. (1989) alapján 
A Délnyugat-Bükkben található az Odor hegy 661 m magasságú hegycsúcsa. Az Odor-hegy és Odorvár környezetét a miocén tengerelöntés hosszabb rövidebb időre elérte, majd a terület a pliocénre ismét kiemelkedett és a szárazföldi lepusztulás lett domináns (Hevesi, 2003).

\subsubsection{Budai-hegység}

A hegység feldarabolódása szerkezetileg középhegységi és erre merőleges csapású törésvonalak mentén történt, aszimmetrikus kibillenésekkel, pikkelyezödésekkel, felboltozásokkal jellemzett alacsony középhegység. A tagoltságára jellemező a sasbércvonulatok közötti medencék (Budakeszi-medence), árkos süllyedékek (Ördögárok), és hegységelőtéri süllyedékek (Zsámbéki-medence) (Schweitzer, 2003).

A Budai-hegység nagyrészt triász korú Dachsteini mészkőből és Fődolomitból épül fel (Kordos, 1984). Átlagos vastagságuk 6-700 méter között változik, a két fácies egymással párhuzamosan ÉNY-DK irányban húzódik (Wein, 1977). A karsztos terület kis területen helyezkedik el 250-550 m tengerszint feletti magasságban. A területet eocén mészkő és márga, oligocén agyag, homokkő, pliocén-negyedidőszaki forrásmészkő vagy lösz fedi (Hevesi, 1991).

A szerkezeti vonalak mentén kiemelkedő hegység, a Duna vonalánál találkozik az Alföld süllyedékével. A repedéseken keresztül a mélységből feláramló meleg vizek utat törtek a felszín felé. Két nagy hévizes fázis különíthető el, az első a miocénbeli vulkáni eredetü, mely vastag kiscelli agyagtakaró alatt tette lehetővé az irányított áramlás kialakulását, utána következett a hő-fluxusból eredő nyitott karsztos tevékenység (Kovács, Müller, 1980). A repedések mentén barlangok keletkeztek a különböző hőmérsékletű vizek találkozásánál kialakuló keveredési korrózió hatására (11. ábra), melyek labirintus alaprajzúak, ásványkiválásokban gazdagok (Kordos, 1984).

A Rózsadombon semmi nem utalt a mélyben húzódó barlangokra, a felszín közelében található járatok némelyike az erózió következtében természetes úton tárulhatott fel. A Szépvölgyi-Rózsadomb térségében található 98 barlangból 9 rendelkezett természetes bejárattal, és 48 kőbányászat során tárult fel. A többi barlang megismerése az urbanizációnak köszönhető, legtöbbjük házalapozás, közmüépítés, útépítés miatt vált ismertté (Virág, et al., 2013). 


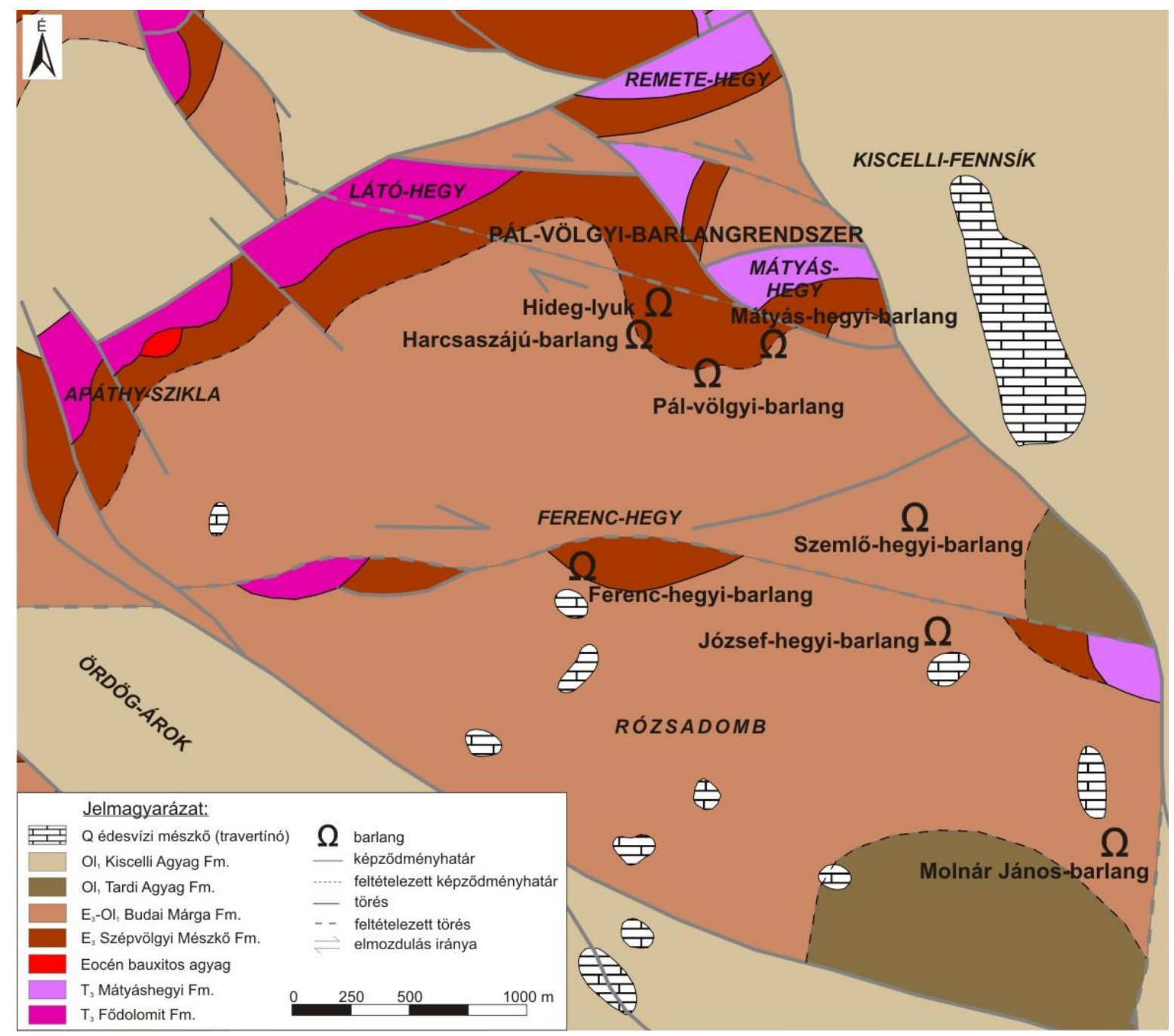

11. ábra Budai-hegység földtani felépítése (Leél-Őssy, 2014)

\subsubsection{Mecsek}

A Magyarország DNY-i részén található Nyugat-mecseki-karsztban kis mérete ellenére igen sok karsztos objektum, köztük barlang előfordul. Kőzettanilag szinte mindegyik azonos - triász korú karbonátos kőzetekben alakult ki (Lovászi, 1971).

A Mecsek karsztosodó kőzetei jelentős karsztvidék kialakulásához elegendő mértékben csak a hegység Ny-i felében fordulnak elő. A Nyugat-Mecsek összefüggő karsztvidéke, mintegy $38 \mathrm{~km}^{2}$ területü, kőzetanyaga a középső-triászban alakult ki. A karsztot fedő réteg É-on és Ny-on jégkori lösz, ÉK-en középső-miocén tengeri üledék, Den triász pala- és homokkő található (12. ábra). A Nyugat-Mecsek tengerszint feletti magassága 300-500 m között változik, kétszintủ hegységperemi karsztvidék. A jurától a miocén közepéig nyílt, a miocénben eltemetett, részben még fedett karsztja két egymás fölötti hullámverési síkon helyezkedik el (Hevesi, 1991). 


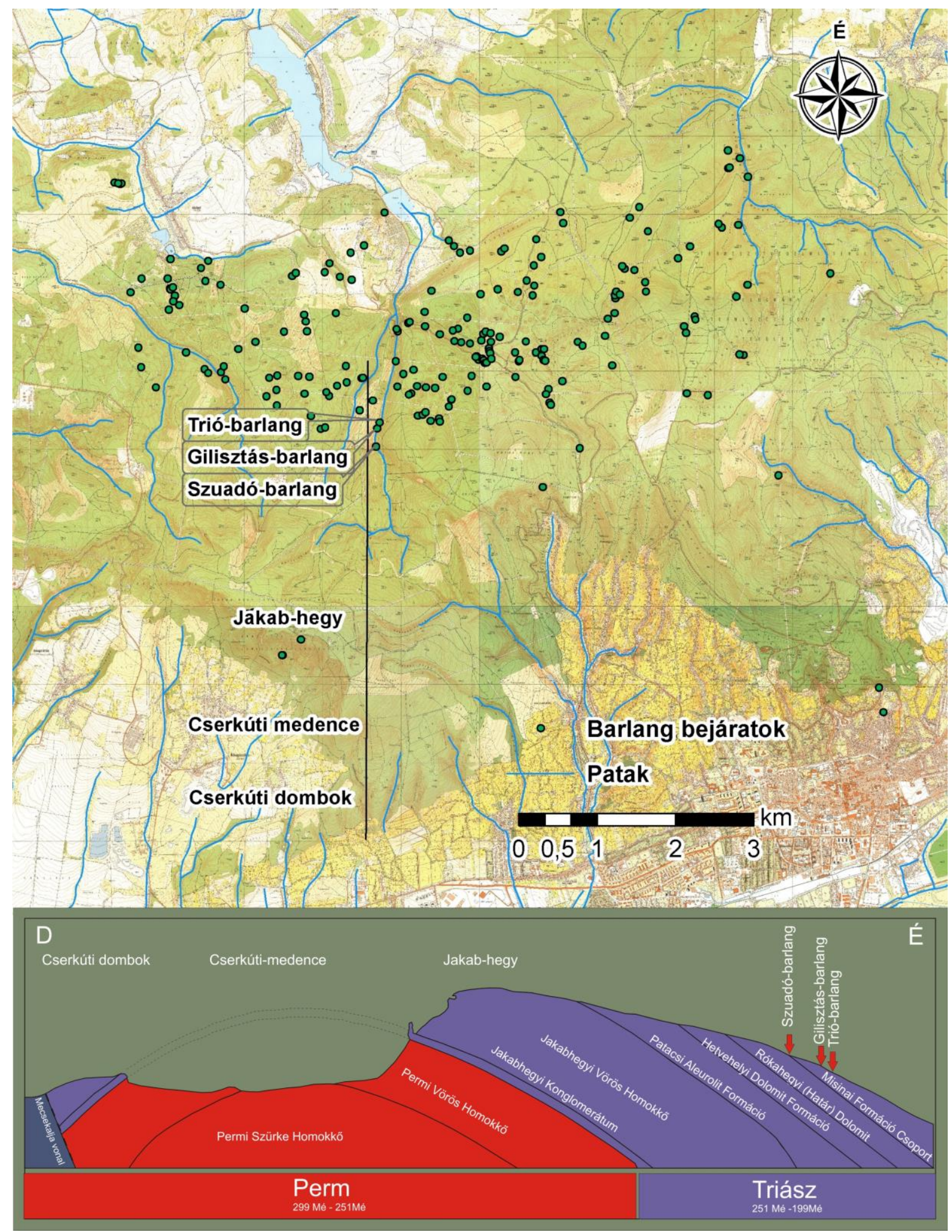

12. ábra A nyugat-mecseki antiklinális vázlatos földtani felépítése (Barta, et al., 2012), valamint a barlangok helyzete a karszton (Szerkesztette: Muladi, Barta alapján) 
A pannon tenger a Nyugat-Mecsek északi részét öntötte el, ennek a vonalát 330370 m-en elhelyezkedő abráziós lépcső mutatja (Barta, et al., 2012). A karsztosodás folyamatos az idősebb és magasabb szinten a szarmatától, a fiatalabb alacsonyabb szinten a pliocéntől napjainkig (Hevesi, 1991). Az abráziós lépcsőnél felhalmozódott vastagabb üledék- és talajréteg miatt nagy dolinák alakultak ki, a legnagyobb átmérője $240 \mathrm{~m}$, mélysége 50-60 m (Lippmann, et al., 2008).

A kihantolódás mértéke kisebb, ezzel magyarázható, hogy az átöröklött völgyeiben sorakoznak a víznyelő töbrök (Hevesi, 1991).

Szabó Pál Zoltán vizsgálatai alapján megállapítható, hogy a Nyugat-Mecsek a negyed-időszakban jelentősen megsüllyedt, de az utolsó időszakban emelkedett. Ennek köszönhetőn völgyek is kialakultak a területen, melyek egy része ma már inaktív, talpukon megjelentek a dolinasorok, mint pl.: a Szuadó-völgyben, az időszakosan aktív patak segítette a völgytalpon a víznyelő barlangok kialakulását (Szabó, 1953; Rónaki, 1970).

\subsection{A barlangok és mintavételi helyszínek bemutatása}

\subsubsection{Hajnóczy-barlang}

A Hajnóczy-barlang a Délnyugat-Bükkben helyezkedik el. A barlang bejárata $457 \mathrm{~m}$ tengerszint feletti magasságban, az Odorvár oldalban található (1. melléklet). Az Odorvár legmagasabb pontja $574 \mathrm{~m}$, a nyugati oldalán a Hór-völgy található. A barlang teljes hossza a $4257 \mathrm{~m}$, vertikális különbség a legmagasabb és legmélyebb pontja között $125 \mathrm{~m}$.

A barlang járatainak iránya É-Ék-D-DNy erre merőleges litokázisrendszerrel. A barlangnak két jól elkülöníthető része van:

- réteglap menti oldással (2. melléklet), majd korróziós folyamatokkal kialakult szükületekben gazdag járatrendszer, amely a bejárattól a Nagy- teremig (3. melléklet) tart, itt a vizsgált szakasz tengerszint feletti magassága 425-457 m között változik, ahol a legmélyebben fekvő rész a Lapos-terem. A bejárattól számított távolság alapján ez a szakasz 235 m-ig terjed (13. ábra).

- föként eróziós folyamatokkal létrejött szakasz, itt nagy formák (pl.: Óriás-terem, amely 40x20 m kiterjedésü) és a nagy termek közötti törmelékhalmok, szükületek (pl.: Mandula: 0,7 m x0,4 m) jellemzőek. A vizsgált szakasz tengerszint feletti. 
magassága 458-500 m között változik, a legtávolabbi pont térbeli távolsága alapján 470 m-re van a bejárattól.

A barlangüregek egy része (bejárati szakasz, Óriásterem) a keveredési korrózió eredményeként jött létre, míg a fedő agyagpala alatti mészkő rétegekben található barlangrészek (Grand-Canyon, Tsitsogó) kialakulásában a sztratigráfia (elváló réteglapok) is jelentős szerepet játszott. A pleisztocénben bekövetkezett relatív karsztvíz nívó süllyedésének köszönhetően a korábban kialakult több szintű üregrendszer szárazzá vált. Hir János vizsgálatai szerint a Hajnóczy barlang egyike a Bükk legidősebb barlangjainak (Hir, 1985). Régészetileg is értékes leleteket hordoz a barlang, hiszen a Galéria járataiban (4. melléklet) olyan medve csontjait (Ursus deningeri) találták meg, mely 700 ezer évvel korábban élt (Kordos, 2002).

A Hajnóczy-barlangban 9 helyszínen lett kihelyezve hőmérsékletregisztráló müszer (13.ábra), törekedve arra, hogy minél változatosabb keresztszelvény méreteknél legyen a hőmérséklet-változás regisztrálva.

A Hajnóczy-barlang nagyobb részben egy felszín közeli barlang (10. ábra). A bejárattól egészen a Lapos-teremig (15. melléklet) folyamatosan mélyül a barlang. A Lapos-terem 55$66 \mathrm{~m}$ vertikális távolságra helyezkedik el a felszíni domborzat alatt, a vizsgálati szakasz legmélyebb része. A Leyla, Mandula és Alsó-Galéria található a legnagyobb vertikális távolságra $(65-80 \mathrm{~m})$ a felszíntől. A Felső-Galériától (16. melléklet) fokozatosan emelkednek a járatok, a kőzet és talajvastagság is egyre vékonyabb $25-50$ m. Az Óriásterem (17. melléklet) helyezkedik el legközelebb a felszínhez (10-24 m), a terem tetején már a fagyökerek is belógnak (Mucsi, et al., 2004).

Az Óriás-terem (5. melléklet)az Odor-hegy csúcsa környékén található, ahol a karsztbokorerdő alatti rendzina talaj a déli kitettség miatt jobban át tud melegedni. A karszt ezen része autogén jellegű (a szivárgó vizek csak csapadékvízből származnak) (Jakucs, 1971), és a barlang vízgyüjtője elég kicsi. Mivel a terem vékony fedőkőzet alatt a hegycsúcs közelében található, így a csapadékvíz gyorsan beszivárog a barlangba. A barlang nagyobb termei a karsztvízszint alatt, keveredési korrózió hatására jöttek létre. A Hór-patak bevágódása a karsztvízszint süllyedését eredményezte, emiatt a termek szárazzá váltak, és a csepegővizek hatására elindult a cseppkőképződés. A csapadék változó mennyiségére utal, hogy a korábbi nedvesebb időszakokban hatalmas cseppkőlefolyás képződött az Óriás-terem K-i falán a mészkőfelszínen (Varga, 2003). Jelenleg csak a csapadékos napok után van csepegés és cseppkőképződés, egyébként az Óriás-terem a 
barlang legszárazabb része. Extrém száraz időszakokban a relatív páratartalom jelentősen csökken és a cseppkövek felszíne szárazzá válik és elindul a cseppkövek degradációja.

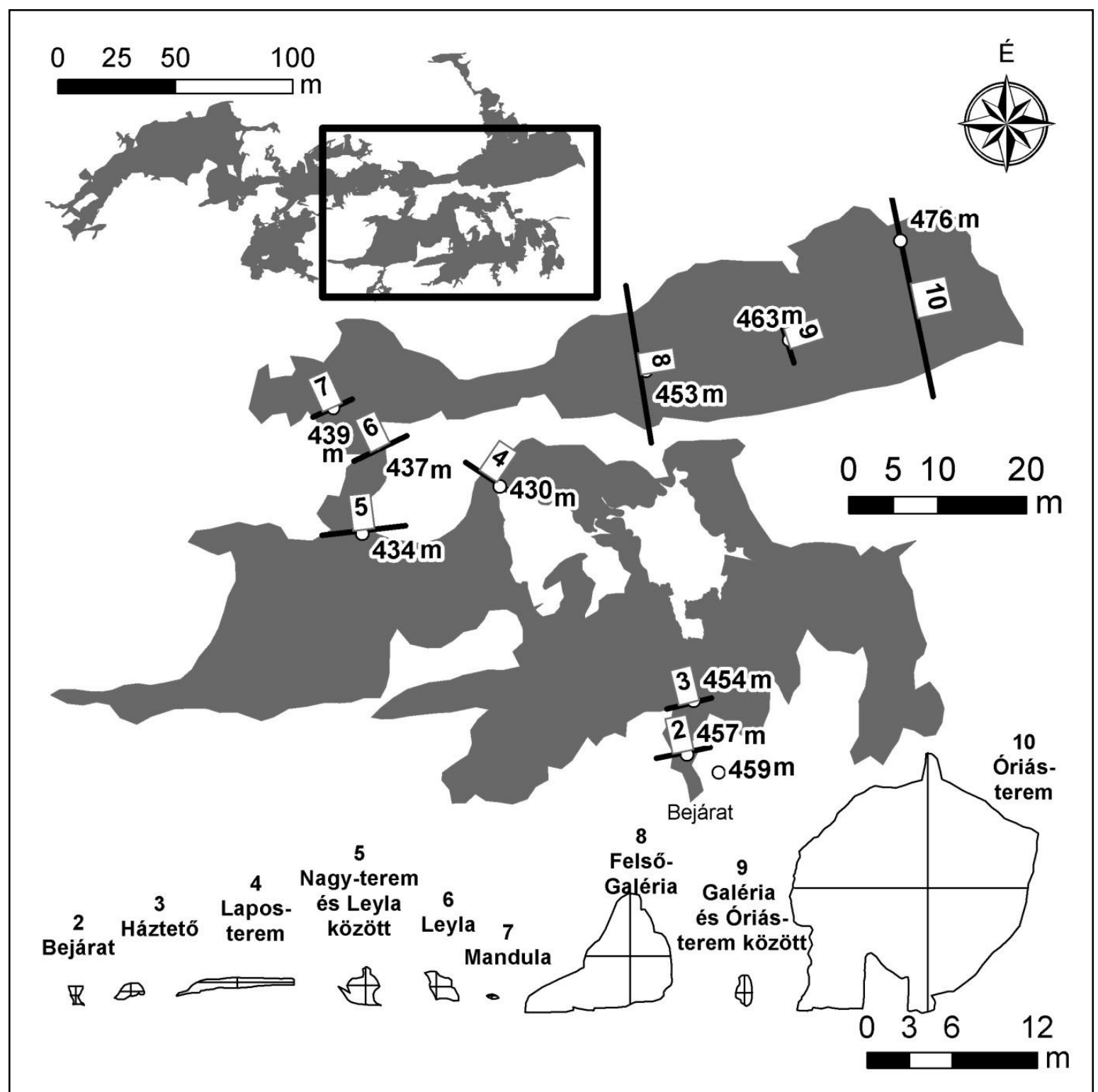

13.ábra A Hajnóczy-barlang léghőmérsékletének vizsgált szakasza, a vizsgálati pontok, azok tengerszint feletti magassága, valamint a keresztmetszete, és azok elnevezései

A barlang klimatikus szempontból statodinamikus jellegű (Fodor, 1981), mert nyáron az egyetlen kijárat teljes keresztmetszetén át áramlik a szabadba a barlangi levegő, télen pedig a felszíni lehülés módosítja a bejárati szakaszt.

Rántó András és Tóth Nikoletta 2010 januárjában hőkamerás képeket készített az Ódorvárról, ahol a barlangi levegő által felmelgítette foltok is jól láthatók a felvételen (14. ábra). 


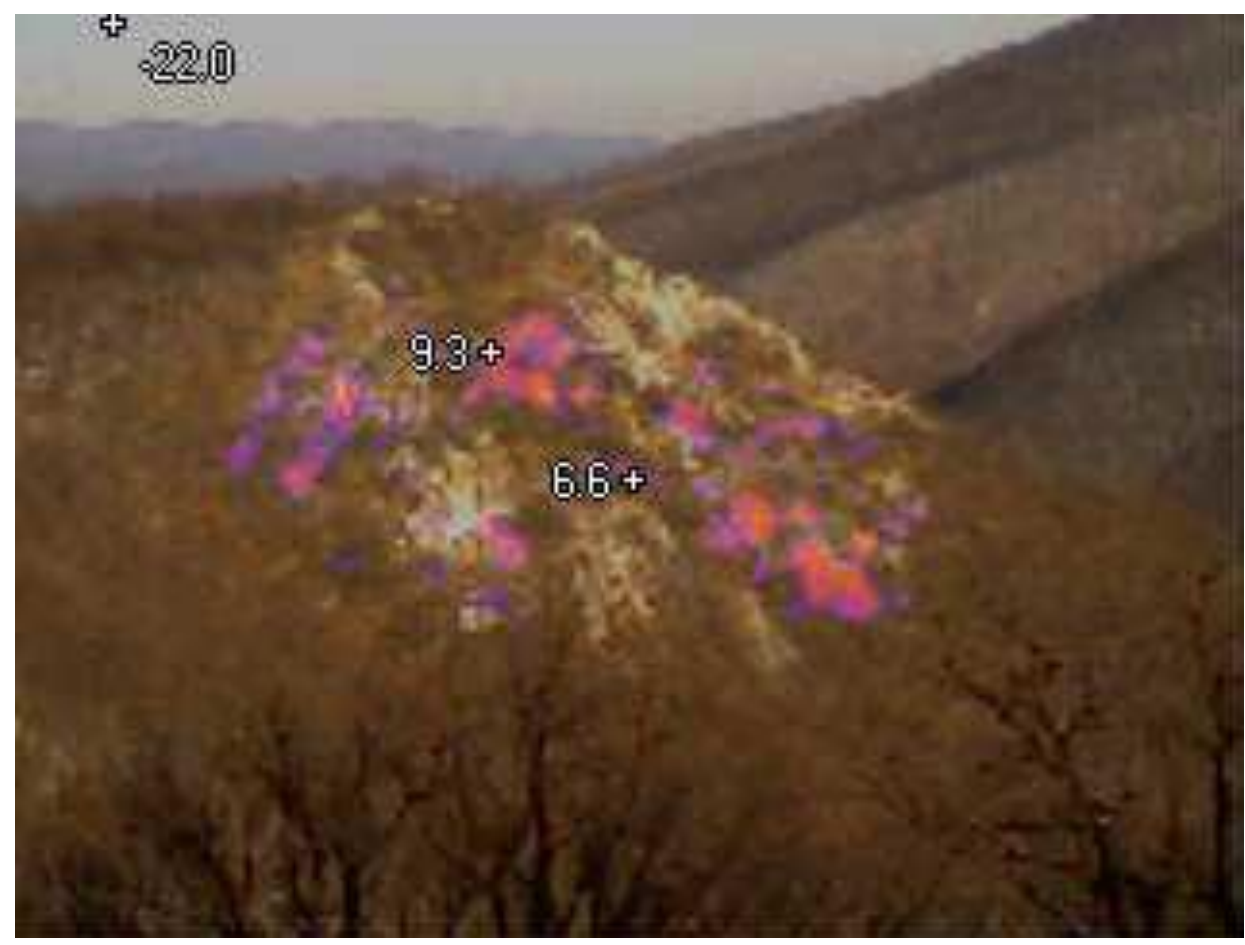

14. ábra Optikai és hőfotó egymásra helyezve az Odorvárról. A felvétel déli Irányból a Mákszemről készült (Rántó \& Tóth, 2010)

\subsubsection{Szép-völgyi-barlangrendszer}

A Hármas-határhegy rögcsoportjában található egykor Holzspach-féle kőfejtőnek nevezett helyen, mesterséges feltárások segítségével nyíltak meg a nagybarlangok bejáratai 1904ben (Kárpát, Takácsné, 1983).

A Pannónia Turista Egyesület 1919-ben alakult meg, fontosnak érezték azt, hogy a nagyközönség számára megnyissák barlangot, így létrákat, lépcsőket, világítást építettek be a barlangba (Kadič , 1920). Az útvonala szinte megegyezik a mai körséta nyomvonalával. A Mátyás-hegyi-barlang járatai 1933-1965 között kerültek feltárásra (Dénes, 2000).

A Bekey Imre Gábor Barlangkutató Csoport 1980-ban kezdte meg a kutatást a Pálvölgyi-barlangban, ahol új lendülettel a barlang 5 éven belül számos új szakasszal bővült a kiépített szakasztól délre (Térképész-ág, December-szakasz, Negyedik. negyed, valamint a Déli-szakasz egy része). A követező években, 1987-1989-ben a barlang Keleti-zónáját tárták fel a kutatók, majd a következő tíz évben a Jubileumi szakasz járataival bővült a barlang (Kárpát, Takácsné, 1983). 


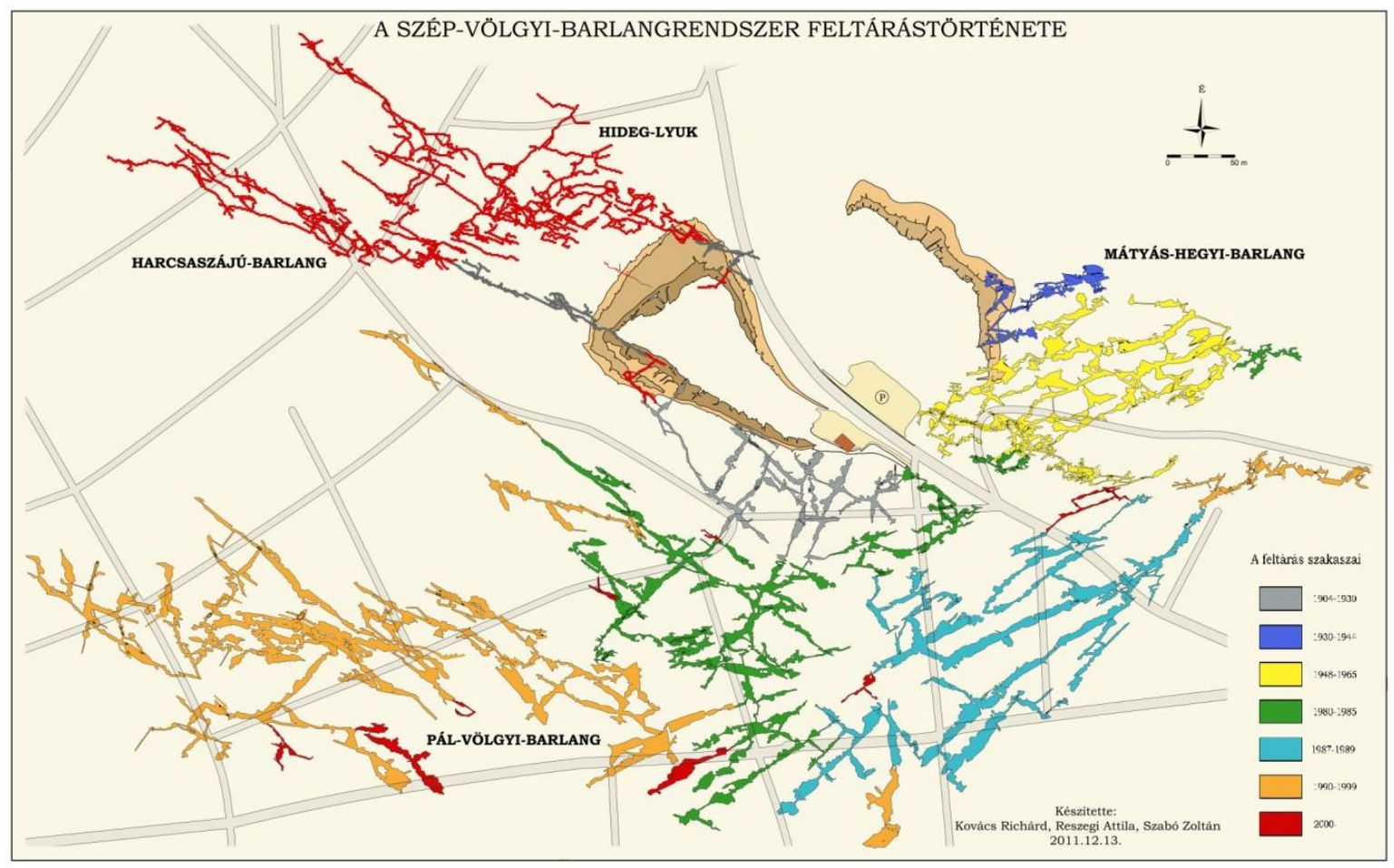

15. ábra A Szép-völgyi-barlangrendszer térképe, és felfedezésének szakaszai (Kovács, et al., 2011)

A 2000-es évektől a Harcsaszájú-barlangban és Hideg-lyukban kezdődtek el a feltárások. A Hideg-lyuk kutatása 2005-ben indult el, a barlang akkor 316 m hosszan volt ismert (Virág, 2013).

A 2011.12.11-én egybenyitott barlangrendszer a Szép-völgyi-barlangrendszer nevet kapta, de Pál-völgyi-barlangrendszerként is jegyzik (15. ábra). A Pálvölgyi kőfejtőben található három nagy (Pál-völgyi-barlang, Hideg-lyuk-barlang, Harcsaszájú-barlang) és ma már öt kisebb barlangot (Meta-barlang, Kis-hideg-lyuk, Bagyura-barlang, Gábor Áronbarlang, Moby Dick-barlang), illetve a szemközti kőfejtőben található Mátyás-hegyi barlangot foglalja magába (Virág, 2013).

\section{Pál-völgyi-barlang}

1904-ben Sholtz Pál Kornél és társai feltárják a kőfejtés során felnyílt Pál-völgyibarlangot, melyet a nagyközönség számára is megnyitnak, 1927-ben gyulladtak fel először a fények. 1980-ban sikerült újabb járatokat felfedezni, Bolner Katalin és Kiss Atilla vezetésével évről évre újabb feltárásokról számolhat be a kutató csoport (Zentai, 2007).

A barlang alaprajzán láthatóvá válik, hogy a víz mozgáspályáit kőzettömeget behálózó törésvonalak szolgáltatták. Az úgynevezett tektonikus preformáció a járatok 
alakját is meghatározza, a törésvonalak föként függőleges lefutásúak, így sok helyen keskeny, de magas folyosók alakultak ki (3.b ábra) (Takácsné, 2003).

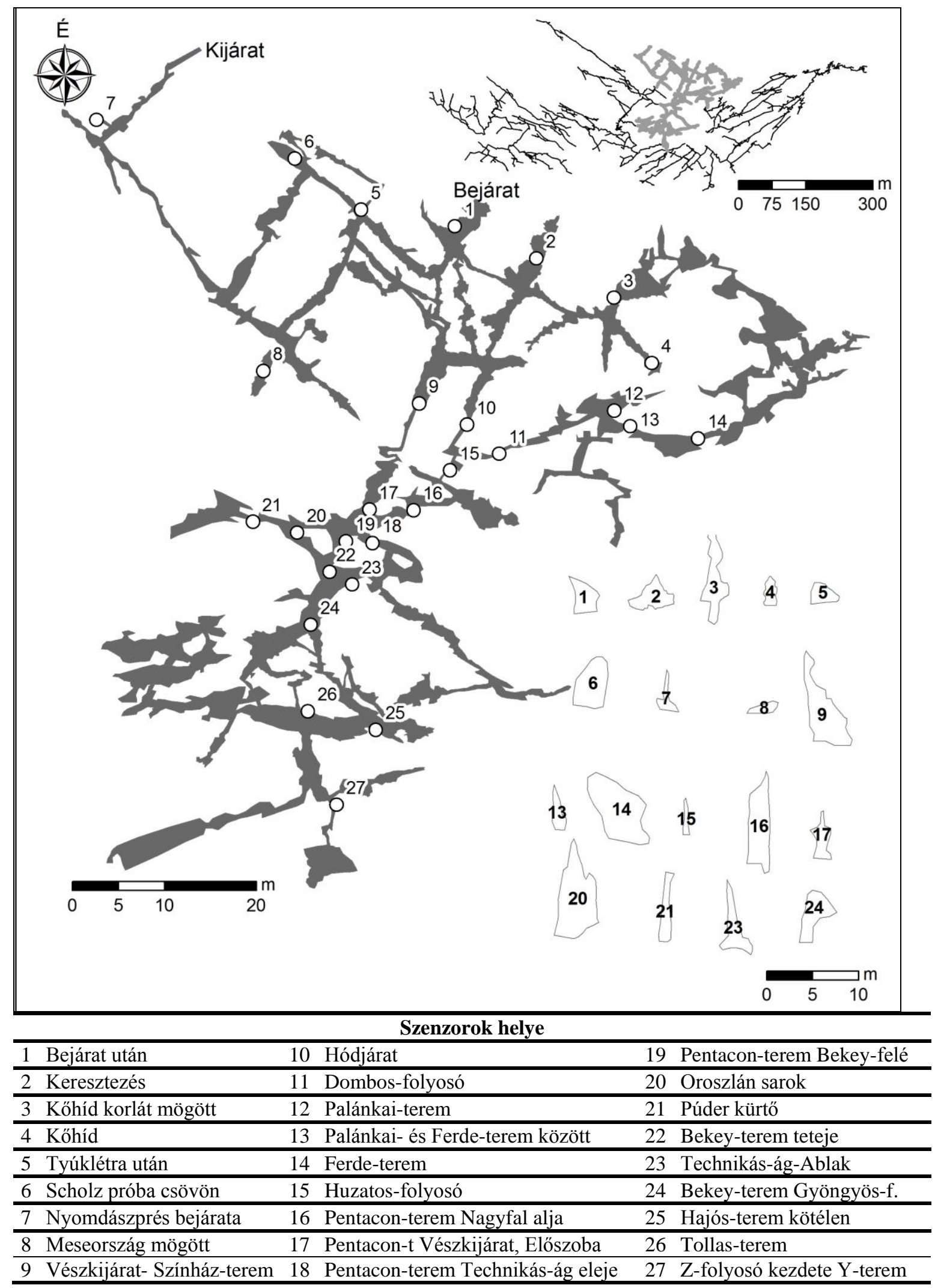

16. ábra A Pál-völgyi-barlang léghőmérsékletének vizsgált szakasza, a vizsgálati pontok, valamint a főbb járatok keresztmetszete, és azok elnevezései. 
A járatok fötéjén jól kirajzolódó törésvonalak mentén gyakran látható az alapkőzet jellegzetes átalakulása a magas kovasavtartalmú, rozsdabarna szegéllyel határolt pár deciméteres kovazóna. Ennek létrejöttét a földtörténeti múltban lejátszódó utóvulkáni müködés okozhatta.

A freatikus hatásnak köszönhető a járatok változó szelvénymérete is, a tágas tereket szük járatok kötik össze, ezek nagysága az adott ponton érvényesülő oldóhatás erősségétől függ. Az oldalfalon és a mennyezeten megjelenő közel szabályos félgömböket formázó fülkék, úgynevezett gömbüstök, az egykor a járatokat színültig kitöltő vízben megjelenő áramlások hatására alakultak ki (Takácsné , 2004).

A barlangjáratok szárazra kerülését 350.000 évvel ezelőttre datálják, ekkorra a tengerszint feletti 160 m-nél magasabban fekvő járatokból visszahúzódott a víz. A barlang sok szakaszán figyelhetők meg omlások, elsősorban azokon a pontokon, ahol a boltozatok túl szélesek voltak, illetve törések is gyengítették (Kordos, 1984)

A Pál-völgyi-barlangban 27 db szenzort helyeztünk ki (16. ábra), K-Ny irányban a Nyomdászpréstől a Tyúklétrán keresztül (9. melléklet), a Ferde teremig, É-D irányban a Bejárattól (10. melléklet) a Z-folyosó kezdete Y-terem (11. melléklet). Mivel a Pál-völgyibarlang esetében az ÉK-DNy, ÉNy-DK, és a KDK-NyÉNy-i tektonikai irányok a döntőek (Leél-Össy, 1995), a müszerek kihelyezésénél fő szempont volt, hogy bejáratra párhuzamos és merőleges járatok futása közötti esetleges légmozgásbeli különbséget kimutassuk. A műszereket ezért helyeztük el egyes helyeken viszonylag közel egymáshoz.

\section{Hideg-lyuk}

A Hideg-lyukat 1908-ban fedezték fel a kőfejtő ÉNy-i legmélyebb pontján, a bejáratban (6. melléklet) érzékelhető erős huzat hívta fel a barlangkutatók figyelmét. 2000-ben a barlang hossza még csak 316 m volt, de ez rohamosan növekedett a Szabó József Barlangkutató Csoportnak köszönhetően, akik 2005-ben kezdték el a barlang kutatását. Napjainkban a Hideglyuk hossza megközelíti a 4 km-t. 


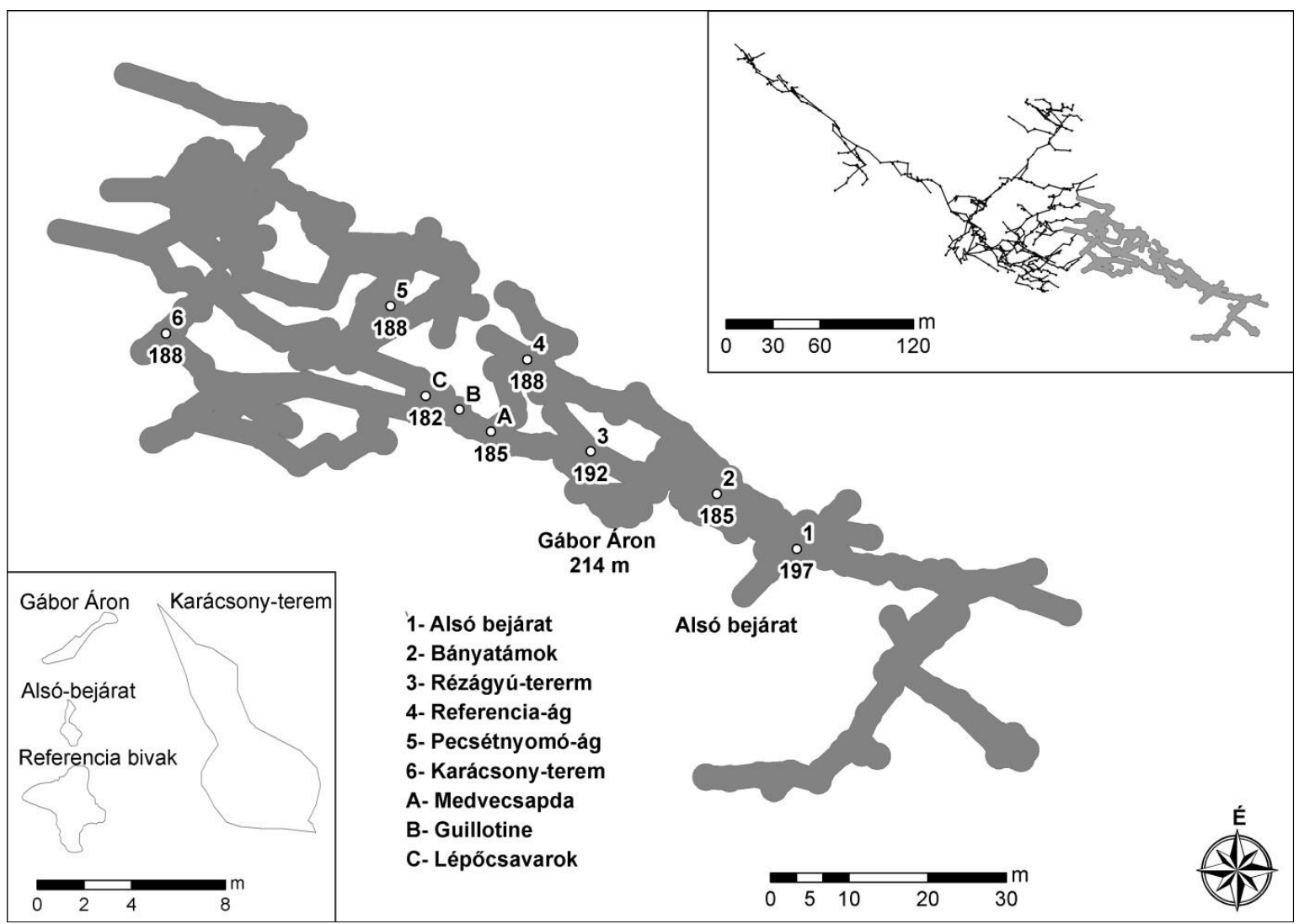

17. ábra A Hideg-lyuk léghőmérsékletének vizsgált szakasza, a vizsgálati pontok, valamint a föbb járatok keresztmetszete, és azok elnevezései.

A barlangot elöször a Hideg-lyuk felett nyíló Gábor Áron-barlanggal sikerült összenyitni, így a barlangot már 2 bejáratból is meg lehetett közelíteni. Ezzel a barlang klimatikus szempontból a statikus légkörzésből dinamikussá alakult. 2010. március 6-án pedig a Harcsaszájú-barlanggal került összeköttetésbe (Nagy, Nagy, 2010). 2011 december 11-én pedig sikerült megtalálni az összeköttetést a Harcsa-Hideglyuk-barlangrendszer, és a Pálvölgyi-Mátyáshegyi-barlangrendszer között, a Meta-barlangon keresztül, így megszületett a 26 km hosszú Szép-völgyi-barlangrendszer (Nagy, Nagy, 2013).

A barlang tágas oldott folyosóit helyenként omladékos termek tagolják (Leél-Össy, 1995). A járatok főként hasadék jellegűek, irányultságuk $300^{\circ}$ és az erre merőleges keresztirányok. Járatok nagy méretekkel rendelkeznek, a falakon oldás nyomai látszódnak. A járatok sok helyen cseppkövekkel gazdagon díszítettek, változatos képződmények találhatók itt. A járatok kitöltése legtöbbször agyag, vagy omladék, de néhol sóder és vízfelület is található, az egyik járatban kalcitkristályok tömege borítja a járattalpat (Nagy, 2010).

A barlangban a vizsgálat során 9 érzékelőt helyeztünk el (17. ábra), míg egyet az Alsó-bejárat közelében (14. melléklet), melyekkel több mint 2 évig monitoroztuk a barlang 
léghőmérsékleti változásait. A bejárat és a Karácsony-terem (7. melléklet) közötti szakaszon téli és nyári légkörzés esetén is mértem. A vizsgálati pontok tengerszint feletti magassága között nincs túl nagy különbség, 197-182 m között változik, a Gábor Áron bejárat nyílik 214 m-en és onnan egy 25 m-es aknával csatlakozik a barlanghoz (Nagy, 2012). A járatok nagysága változatos a Karácsony-terem akár a 10 m-es magasságot is elérheti.

\section{Harcsaszájú-barlang}

A Harcsaszájú-barlang mesterséges úton tárult fel a Szépvölgyi út mellett a századfordulón müködő kőfejtőben. Déry József 1902-ben leereszkedett a kőbánya nyugati sarkában található hatalmas tölcsérszerü nyílással bíró barlangba (Nagy, 2014).

A nevét a megközelítőleg 5m-es átmérőjü kör alakú bejáratáról kapta (Nagy, 2014). A barlang kutatása 1964-ben kezdődött meg Kessler Hubert vezetésével. A bejáratban felhalmozódott törmeléket eltávolítva ismét járhatóvá tették a bejáratot. A bejárat utáni szakasz egy meredeken lejtő, folyamatosan szükülő „V” alakú járat (Leél-Össy, 1995). A barlang újbóli kutatását 2006-ban a Barit Barlangkutató Csoport kezdte meg. a Malacfürdö nevü végpontnál, ekkor a barlang $660 \mathrm{~m}$ hosszú és $44 \mathrm{~m}$ mély volt. 2008-ban sikerült további 2 km-rel gyarapítani a barlang hosszát, és 2010-ben pedig újabb 1,2 km-et fedeztek fel.

A barlangot magas hasadékokból és tágas termekből álló, főleg horizontális kiterjedésű, labirintus-jellegü járathálózat jellemzi, melyet nagy mennyiségü agyag tölt ki (Nagy, 2014).

A Harcsaszájú- barlangban egy rövidebb időszakaszban mértünk egy nyári periódust választottunk ki. A 13 db müszert úgy helyeztük el a járatokban (18. ábra), hogy a barlang különleges bejárati zónájában több különböző helyet is vizsgálhassunk, illetve a több kisebb barlang felé indultak innen kutatások, és hogy ezeket a végpontokat is vizsgálhassuk. 


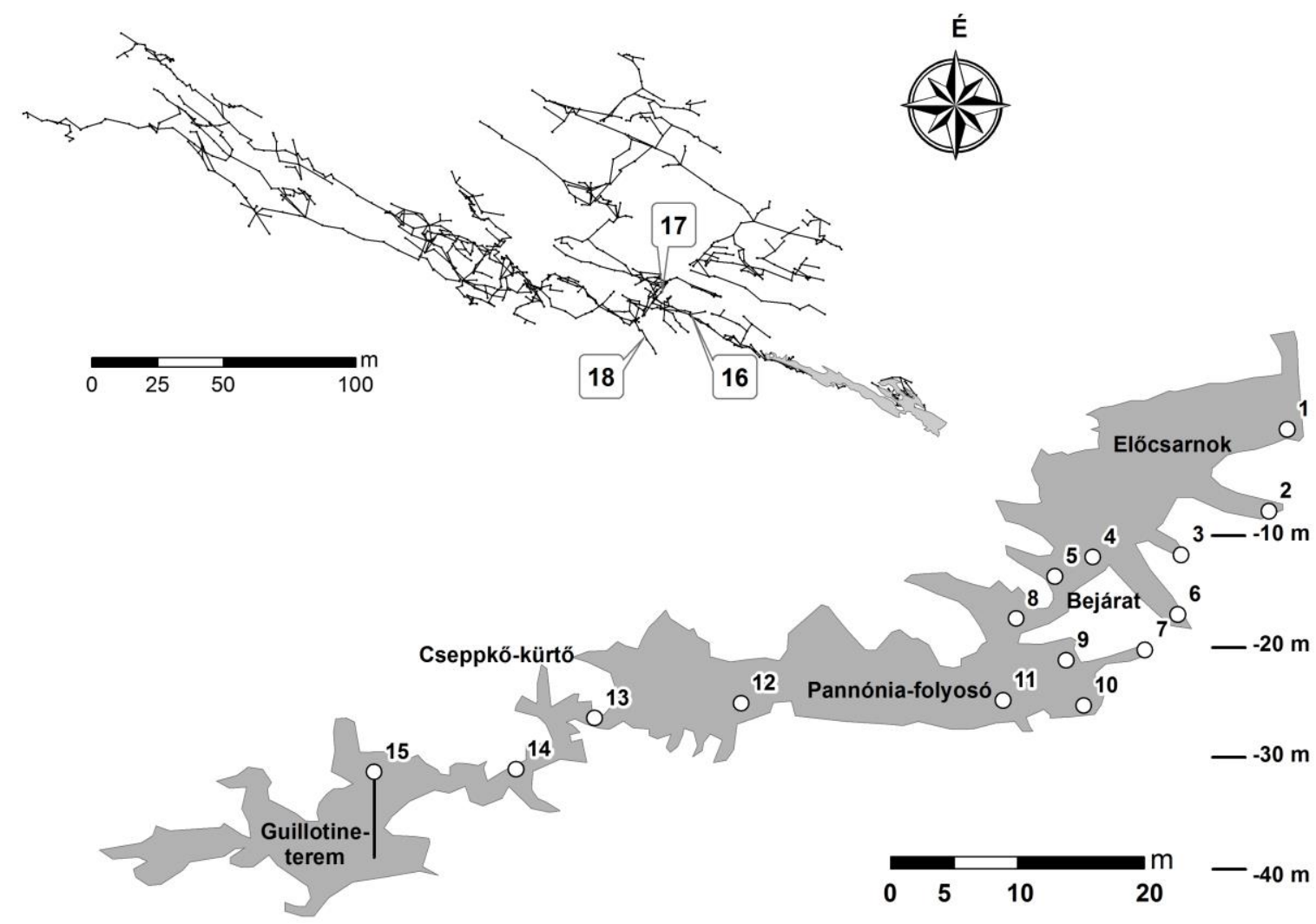

\begin{tabular}{ll}
\hline & Szenzorok helye \\
\hline 1 Harcsaszájnál felszínen & 10 Pannónia folyosó kezdete \\
\hline 2 Bontás a Harcsaszáj alatt & 11 Pannónia-folyosó \\
\hline 3 Bagyura-barlang felé bontás & 12 Lépöcsavarok, cseppkövek \\
\hline 4 Bagyura-barlang felé & 13 Cseppköves-kürtö teteje \\
\hline 5 Bejárat fölött & 14 Omladék Guillotine elött \\
\hline 6 Bagyura-barlang fölötti járat & 15 Guillotine vertikális vizsgálat \\
\hline 7 Bagyura-barlang alatti járat & 16 Belyukadás \\
\hline 8 Bejárat után & 17 Új rész kötélen vertikális vizsgálat \\
\hline 9 Bejárati akna közepe & 18 Tej bontás \\
\hline
\end{tabular}

18. ábra A Harcsaszájú-barlang vizsgált pontjai keresztmetszeti, és alaprajzi térképen valamint a járatok elnevezései.

A barlangot a Pannónia-folyosón keresztül egészen a Malacfürdőig vizsgáltuk. A vertikális különbség a vizsgált szakaszon $40 \mathrm{~m}$. A Bejárati-termet és a Pannónia-folyosót egy szükebb szakasz választja el egymástól. A Pannónia-folyosó és a Malacfürdő között található a Cseppköves kürtő, mely ismét egy szükebb járatszakasz. A BARIT barlangkutató csoport tagjai 2008. július 21.-én jutottak tovább a Belyukadás nevủ pontnál (BARIT 2010). 


\subsubsection{Trió-barlang}

A Szuadó-völgyben található Trió-barlang a 255 méteres hosszával és -58 méteres mélységével, a Mecsek második legmélyebb és hetedik leghosszabb barlangja, bejárata 297 m magasságban található. Tipikus völgytalpi víznyelő barlang, jelenlegi állapotában már csak időszakosan aktív. A völgy három barlangja közül feltételezések szerint a legidősebb, de a nyelök szimultán müködtek, így nem feltétlenül jelenti azt, hogy a legfejlettebb (Barta, Tarnai, 1997).

A barlangot morfológiailag három részre lehet osztani:

1. A bejárattól (12. melléklet) az aknarendszerig tengerszint feletti magassága 294-278 m között változik szük egyenletes lejtésű 30 méter hosszan.

2. A következő szakasz három függőleges aknából és a hozzájuk tartozó vízszintes részekből áll (tszf. 278-260 m).

3. Majd a harmadik akna után ismét kisebb lejtésű szakasz található (tszf. 259242 m), melyben az Elágazás után az Agyagos-ágon és Vizes-ágon eljuthatunk a barlang két végpontjára (Bauer, M. Tóth, 2011).

A barlangot befoglaló kőzet 240 millió éves története alatt számos részre töredezett, melyek vetők mentén elmozdultak, így a barlangok kutatása meglehetősen nehéz feladat, melyet nagymértékben megkönnyíthetnek a barlangi klimatológiai vizsgálatok. A barlangokat befoglaló kőzetet napjainkban jelentős vastagságban különböző típusú talajok borítják, melyek feltehetőleg erősen korlátozzák a barlangi légtér és a felszín közötti légcserét a mikro töréseken keresztül. A barlangot fedő kőzet és talaj vastagsága $96 \mathrm{~m}$ a barlang mélyebb szakaszain, ebből kifolyólag az ismert légcsere feltehetőleg a fejlettebb járatrendszerekhez kötődik.

Klimatikus barlangtípusok közül a Trió-barlang a statikus barlangok közé tartozik, és mivel a hegy belseje felé haladva süllyed a barlang, így ez egy hidegebb statikus barlang (Fodor, 1981).

A Trió-barlangban $12 \mathrm{db}$ müszer került elhelyezésre a barlang különböző járatszakaszaiban. A barlang szük keresztmetszetü első szakaszába két müszer került, a bejárat után a Gerinctörőhöz, és a Könyvtárhoz (19. ábra). A második szakaszban, az akna rendszernél 4 müszer mért a Búbos kemence mellett (13. melléklet), a Rétes-teremben, a Tamás-aknában, illetve a Brassói-ágban. Az aknarendszer követően újra egy kisebb keresztmetszetü járat következik, mely az Elágazásig tart, itt 2 müszer volt a 3-as akna és a 
Nagyköves terme között, és a z Elágazásnál. A Vizes-ági végponton az Őrszem-teremben volt egy müszer, az Agyagos-ágnál pedig az Ékszerdobozban és a Kútban.

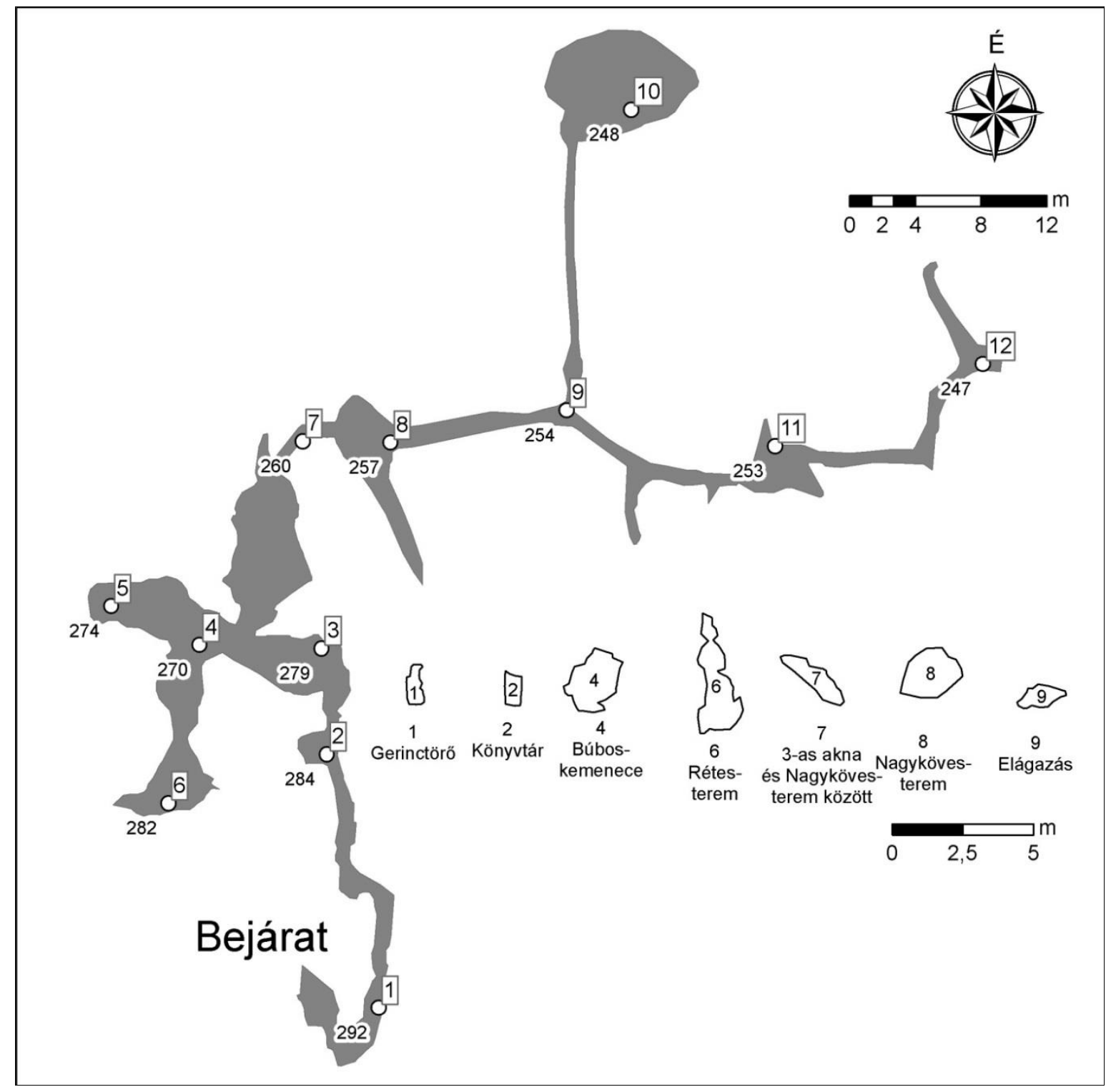

\section{Szenzorok helye}

\begin{tabular}{llll}
\hline 1 & Gerinctörö & 7 & 3-as akna és Nagyköves-terem között \\
\hline 2 & Könyvtár & 8 & Nagyköves-terem \\
\hline 3 & Búboskemence & 9 & Elágazás \\
\hline 4 & Tamás-akna & 10 & Őrszem-terem \\
\hline 5 & Brassói-ág & 11 & Ékszerdoboz \\
\hline 6 & Rétes-terem & 12 & Agyagos-ág Kút \\
\hline
\end{tabular}

19. ábra A Trió-barlang alaprajzi térképén jelölt müszerek helye, és tengerszint feletti magasságuk, valamint a járatok keresztmetszetei és azok elnevezése. (SZKBE, 2002 után módosítva ) 


\section{Vizsgálati módszerek}

\subsection{Méréstechnológia a barlangban}

A feltáró kutatások során a több évig tartó megfigyelések alapján az egyes járatok közötti átjárhatóságot számos eszközzel vizsgálhatják. A technika fejlődésével a modern eszközök használatával pl. CB-rádió-, légáramlás-, hőmérséklet-, areosol-, $\mathrm{CO}_{2-}$, radon mérések és geofizikai vizsgálatok segíthetik a továbbjutás esélyét (Virág, 2013).

Kezdetben higanyos hőmérőket helyeztek el a barlangban és egy-egy látogatás alkalmával feljegyzéseket készítettek róla (Kordos, 1970). Ezek a mérések néhány tájékoztató adatot adtak, viszont a technika fejlődésével egyre nagyobb igény volt az automata mérőrendszerekre. Az aggteleki barlangok meteorológiai viszonyait elsősorban öníró müszerek szalagjaira rögzítették. Az 1960-as években Csomor Mihály és Zalavári Lajos alkalmazott ilyen müszereket, és megállapították, hogy nem teljesen alkalmasak barlangklimatológiai vizsgálatokhoz a nagy mérési tartományuk miatt, de a bejárati és a kiegyenlítődési szakaszban mégis tudták rögzíteni a hőmérséklet-változásokat (Csomor, Zalavári, 1964; Fodor, 1980).

A technika fejlődésével egyre szélesebb körben lehetett nagyobb pontosságú automata adatgyüjtőkhöz jutni (Böckler, et al., 2012). Az egyes paraméterek mérése, mint pl.: hőmérséklet, légnyomás, páratartalom, szén-dioxid koncentráció, radon, légmozgás, csepegés mérés, víznyomjelzés esetén más-más technikai adatok jellemzők. Az egyes tényezők esetében a fontos tudni, milyen érzékenységgel és pontossággal válasszuk a vizsgálatokhoz a müszereket (5. táblázat). A precíziós mérésekhez szükséges, hogy a hőmérséklet észlelése $10^{-3}{ }^{\circ} \mathrm{C}$ felbontású legyen valamint a pontossága $10^{-2}{ }^{\circ} \mathrm{C}$ értékü legyen (5. táblázat). Vannak olyan müszerek, melyekkel nem lehet a megfelelő érzékenységet, vagy pontosságot elérni, ezzel az adatok feldolgozásakor tisztában kell lenni, nehogy fals következtetésekhez jussunk. Ilyen esetekben elengedhetetlen a müszerek kalibrálása. Néhány olyan müszert említenék meg, melyeket napjainkban a barlangkutatásban egyre többen alkalmaznak. 
5. táblázat Barlangi paraméterek méréstechnológiai tartományai (Fairchild, Baker, 2012)

\begin{tabular}{|c|c|c|}
\hline Paraméterek & Technika & Érzékenység / mérés pontossága \\
\hline \multirow{5}{*}{$\begin{array}{l}\text { Levegö és a viz } \\
\text { hömérséklete }\end{array}$} & \multirow{5}{*}{$\begin{array}{l}\text { a) Higanyos hőmérő (száraz hőmérő) } \\
\text { b) Elektromos hőmérő } \\
\text { c) Optikai szálas hőmérséklet- } \\
\text { érzékelő }\end{array}$} & a) $0,05^{\circ} \mathrm{C}$ \\
\hline & & b) Pontosság $0,01-0,05^{\circ} \mathrm{C}$ \\
\hline & & felbontás $0,001-0,01^{\circ} \mathrm{C}$ kalibrálás \\
\hline & & szükséges \\
\hline & & $\begin{array}{l}\text { c) Térbeli pontossága legfeljebb } \\
0,01{ }^{\circ} \mathrm{C}\end{array}$ \\
\hline Légnyomás & Elektromos nyomásérzékelő & $0,1 \mathrm{mb}($ millibar $=\mathrm{hPa})$ \\
\hline \multirow{2}{*}{ Páratartalom } & \multirow{2}{*}{$\begin{array}{l}\text { a) Hütött tükör higrométer } \\
\text { (harmatpont) } \\
\text { b) kapacitív érzékelő }\end{array}$} & $\begin{array}{l}\text { a) } 1 \% \text {-os pontossággal, } 0,1 \% \text {-os } \\
\text { felbontás; } 99 \% \text {-os páratartalomig } \\
\text { müködik }\end{array}$ \\
\hline & & $\begin{array}{l}\text { b) } 2 \% \text {-os pontossággal, } 0,1 \% \text {-os } \\
\text { felbontás; } 98 \% \text { fölötti relatív } \\
\text { páratartalom esetén nem müködik }\end{array}$ \\
\hline \multirow[t]{3}{*}{$\begin{array}{l}\text { Szén-dioxid } \\
\text { koncentráció }\end{array}$} & $\begin{array}{l}\text { a) Infravörös spektroszkópiával (pl } \\
\text { Vaisala CARBOCAP® GM70 kézi } \\
\text { eszköz, vagy GM353 nagyobb } \\
\text { pontossággal) }\end{array}$ & \multirow{3}{*}{$\begin{array}{l}\text { a) Felbontás } 1-10 \text { ppm, pontosság } \\
1-10 \% \text { mely függ a szonda } \\
\text { típusától. } \\
\text { b) } 10 \% \text {-os pontosságú } \\
\text { Légzőkészülékre lehet szükség. }\end{array}$} \\
\hline & b) Reagens csövek & \\
\hline & (pl Dräger -cső TM) & \\
\hline \multirow{4}{*}{ Radon mérés } & \multirow{4}{*}{$\begin{array}{l}\text { a) Valós idejủ mintavételezés (pl } \\
\text { alfa-számláló, vagy folyamatos } \\
\text { detektálása a radonnak } \\
\text { Radon bomlástermékének mérése } \\
\text { Filteres mintavétel } \\
\text { b) Kumulált mintavétel: pl. } \\
\text { maratásos nyomdetektor }\end{array}$} & $\begin{array}{l}\text { a) Pontosság } 5-10 \% \text {, de a mérési } \\
\text { időtől függ }\end{array}$ \\
\hline & & $\begin{array}{l}\text { 1dotol fugg } \\
\text { b) Precíziós > 10\%; a bomlástermék }\end{array}$ \\
\hline & & viselkedése bezavarhat \\
\hline & & \\
\hline \multirow{3}{*}{ Légmozgás } & a) Füst vagy gőz megfigyelése & a) $<1 \mathrm{cms}^{-1}$; félig kvantitaív \\
\hline & $\begin{array}{l}\text { b) Hő drótos anemométer (nem lehet } \\
\text { az irányt megállapítani) }\end{array}$ & $\begin{array}{l}\text { b) } 0,1 \mathrm{~ms}^{-1} \text { kimutatási határ, } \\
\text { pontosság } 5 \%\end{array}$ \\
\hline & c) Ultrahangos anemométer & c) $1 \mathrm{cms}^{-1}$ \\
\hline \multirow[b]{2}{*}{ Csepegés mérés } & \multirow{2}{*}{$\begin{array}{l}\text { a) Vízgyüjtés } \\
\text { b) Csepegés intenzitásának mérése }\end{array}$} & $\begin{array}{l}\text { a) } 1 \% \text {-os pontossággal, rövid } \\
\text { periódusokban }\end{array}$ \\
\hline & & $\begin{array}{l}\text { b) } 1 \% \text {, ha csepp mérete is ismert; } \\
\text { mérési lehetösége akusztikus } \\
\text { méréssel, vagy infravörös sugárral }\end{array}$ \\
\hline Viznyomjelzés & $\begin{array}{l}\text { Különböző technikák együttes } \\
\text { használata pl. sózással, } \\
\text { fluoreszeinnel }\end{array}$ & Általában $10 \%$-os pontossággal \\
\hline
\end{tabular}

A Testo 405 Elektromos hőmérők típusába tartozik (5. táblázat Barlangi paraméterek méréstechnológiai tartományai (Fairchild, Baker, 2012) már egy komplexebb kézi mérő, mivel lehet vele hőmérsékletet és légáramlást is mérni. A hőmérséklet mérés esetén a pontossága $\pm 0,5^{\circ} \mathrm{C}$, felbontása $0,1^{\circ} \mathrm{C}$, míg a légáramlás mérés esetén a felbontás $0,01 \mathrm{~m} / \mathrm{s}$, 
a mérés tartománya 0-10 m/s (Testo, 2015). A barlangok bejárati szakaszában, illetve szük keresztmetszetü helyeken a hődrótos anemométer is mutat különbségeket.

Az adatrögzítők közül nagyon népszerü az iButton DS1921Z verziója, mely -5 és $+26{ }^{\circ} \mathrm{C}$ között mér a pontossága $+/-1{ }^{\circ} \mathrm{C}$, az érzékenység $0,125^{\circ} \mathrm{C}, 2048$ adatot tud eltárolni és a mérési időköz 1 és 255 perc között választható. Mérete nagyon kicsi, egy gomb elemnyi, a tartozékával könnyen rögzíthetö falra is. Az adatok kiolvasásánál óvatosan kell bánni a különböző helyeken lévő szenzorok összehasonlításával, mert barlangon belüli $1{ }^{\circ} \mathrm{C}$-os különbség az sok, lehet, viszont a felszíni változások nyomon követésére alkalmasabb lehet.

A különböző vizsgálati tényezőknél a müszerek szempontjából lehet egyszerü kézi mérést végezni, ezeket a méréseket bizonyos időszakonként ismételni szükséges. A másik eshetőség, mikor a barlang kijelölt pontjain nagy pontosságú, sok komponenst vizsgáló meteorológiai állomás kiépítése szükséges. Az ilyen típusú vizsgálatok főként turisztikai hasznosítás esetén válhatnak szükségessé, a barlangba látogató turisták által módosított klimatikus paraméterek meghatározásakor (Kaffai, Imecs, 2008). A Pál-völgyi-barlangban is kiépítésre került egy ilyen állomás Nagy Hedvig Éva radon vizsgálati időszakára, amely a szélirány, szélsebesség, hőmérséklet, relatív páratartalom, légnyomás és csapadékmennyiség mérésére alkalmas volt. A hőmérséklet felbontása $0,1^{\circ} \mathrm{C}$-os volt a müszernek, mely a bejárattól nem messzire lett telepítve. A müszer egy órás intervallumonként mérte a paramétereket (Nagy, 2012).

Egyre könnyebb manapság beszerezni infra hőmérőt vagy kamerát, ezen eszközök segítségével is lehet körülbelüli adatokat gyüjteni, de ezek a müszerek a kőzet és az üledék hőmérsékletét mérik. Habár az infravörös termo kamerát nagyon széles körben használják (épület energetikai vizsgálatok, a vadállatok megfigyelése, orvosi alkalmazások, stb.) a barlangklíma vizsgálatokra viszont nagyon kevés példa fordul elő. A közelmúltban a Morva-karszton a Kateřinska-barlangban történtek vizsgálatok, ahol kőzethőmérsékletet infrakamerával vizsgálták, és kiegészítették a HOBO léghőmérsékletmérőkkel (Středová, et al., 2014). Ennek során a felszíni hőmérséklet lokális hatásait vizsgálták a barlangban. Ilyen típusú vizsgálatok történtek még Peña Castil jégbarlangban Észak-Spanyolországban (Berenguer-Sempere, et al., 2014). Magyarországon Surányi Gergely és munkatársai alkalmazták a Csévi-szirteken a felszíni hőmérséklet-anomáliák vizsgálatára. Hideg, havas téli napon kigőzölgéseket vagy olvadási foltokat kerestek, mely egyszerű módszer segítségével, jelentős sikerek is születtek, ennek köszönhető például az Ösi-barlang felfedezése (20. ábra) (Surányi, 2008). 

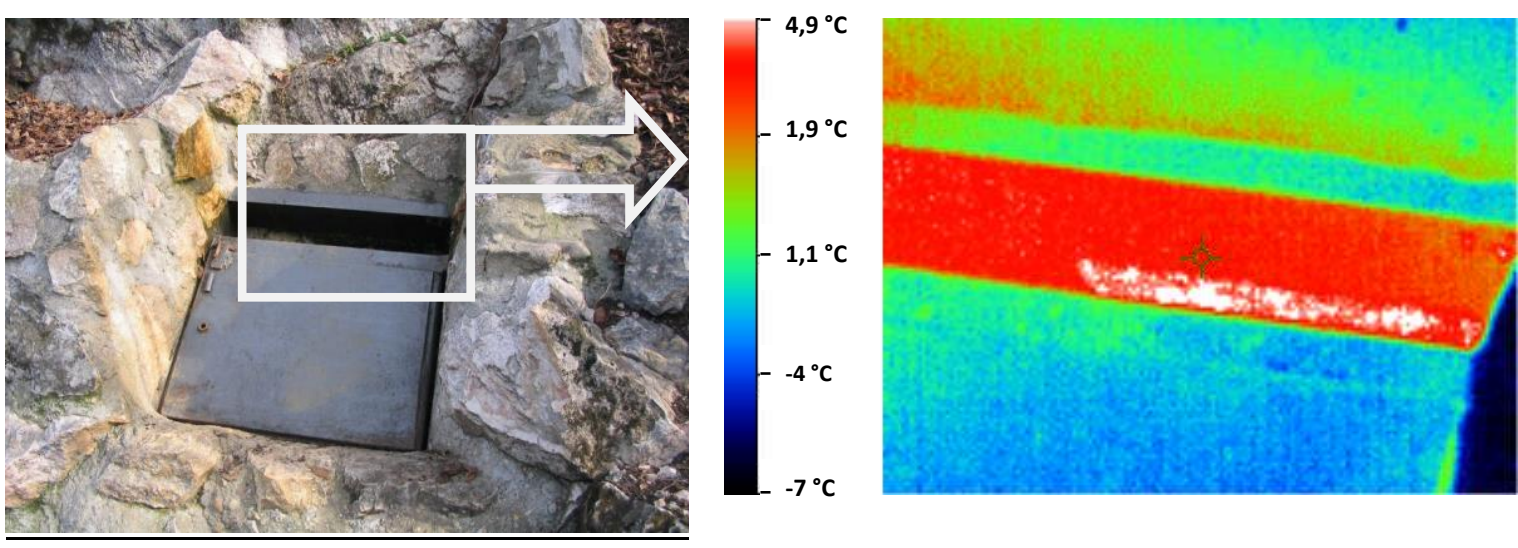

20. ábra Ösi-barlang bejárata és arról készült infrakép (Surányi, 2008)

\subsection{Vezeték nélküli adatrögzítők}

Ahogy a vezeték nélküli szenzorhálózat technológiája fejlődött, úgy vele együtt az erre épülő alkalmazások is egyre jobban bővültek. A szenzorhálózat általános jellemzői közé tartozik az olcsóbb beszerezhetőség, valamint alacsony fogyasztás, ugyanakkor rövid hatótávolsággal müködnek. A hálózatot alkotó node-ok általában kis méretủek, a processzor és a memóriája limitált. A szenzorhálózati eszközök alkalmazása esetén elkerülhető a drága vezetékes eszközök telepítése, helyettük könnyen kihelyezhető, rádió kommunikációra alkalmas eszközök használhatók. Az eszközök bővíthetők plusz érzékelőkkel, melyek segítségével több paraméter is mérhető (Lengyel, 2007).

A Szegedi Tudományegyetem "Szenzorhálózat alapú adatgyüjtés és információfeldolgozás" (TÁMOP-4.2.2-08/1/2008-0001) című projekt keretein belül fejlesztésre került két olyan müszer, melyekről tesztelések bebizonyították, hogy alkalmasak a barlangklíma mérésre. Az egyik müszer a TelosB a másik az UC Mote Mini szenzor. Mindkét müszerre jellemző, hogy egy mérőállomás kiépítéséhez képest az alacsonyabb költségvetésü müszerek közé sorolhatók, alacsony fogyasztási szinttel rendelkeznek, valamint lehetőség van a vezeték nélküli kommunikációra.

Az eszközök müködtetéséhez TinyOs-ben készültek el a megfelelö programok, melyek egy $\mathrm{C}$ alapú programozási nyelvre épülnek. Míg a felhasználóval való kommunikációra szolgáló szoftverek Java-ban készültek. A hőmérsékletmérő programnak két fő eleme van.

Az egyik elem valósítja meg a hőmérsékletmérést. Ezen programrész bizonyos időközönként lekéri az hőmérsékletszenzor adatait, melyet ezután eltárol a flash memóriába. Egy letárolt csomag a hömérsékletértékböl és a mérés időpontjából áll. A tároláshoz a program a TinyOs LogStorage modulját használja, melynek segítségével 
kisméretü adatokat tudunk biztonságosan tárolni. Ha a rendszerben bármi hiba történik, pl. áramellátás megszünése, akkor sincs adatvesztés. Az adattárolás kétféle módon történhet: az egyik a lineáris, amikor a tárolás megáll amint a memória betelt. Másik lehetőség a cirkuláris tárolás, ekkor a memória megtelése után mindig az utolsó adatot írja felül. A cirkuláris adattárolás előnye, hogy az utolsó két adatból már el tudjuk dönteni, volt-e adat veszteség.

A másik fö eleme a programnak az IEEE 802.15.4 szabványra épülő rádiós kommunikáció. A rádió vezérlése során két protokollt alkalmazunk (Muladi, Csépe, 2012). FTSP (Flooding Time Synchronization Protocol),

Ha vezeték nélküli szenzorhálózatot építünk ki, akkor általában több szenzor alkalmazásáról esik szó. Az eszközök szinkronizálása jelentősen megkönnyítheti munkánkat az adatok feldolgozásakor. Az eszközök alapesetben szinkronizálatlanok, mert nem minden szenzor processzora megy ugyanazzal a sebességgel, ez lehet akár 7, 9 de 8,1 MHz is a gyári 8 Mhz-cel szemben. Ez függ a külső hőmérséklettől, a rázkódástól és egyéb környezeti tényezőktől. Az eszközök lokális időmérővel rendelkeznek, ezért nem tudjuk pontosan megadni a mérések egymáshoz való viszonyát. Az FTSP segítségével globális időt számítunk ki, amely minden eszközön megegyezik. Lokális idő az eszköz helyi ideje, a globális idő az egész szenzorhálózatban adja meg az időt (Maróti, et al., 2004).

LPL (Low Power Listening).

Az LPL segítségével az energiafogyasztás minimalizálható, hogy az elemeket minél hosszabb ideig tudjuk használni. Energiatakarékosság céljából a rádió nem folyamatosan üzemel, csak meghatározott időközönként. Ha tehát egy szenzor üzenetet továbbít egy másiknak, bekapcsolja a rádiót és elkezdődhet az adatok továbbítása. Majd fogadó üzemmódra vált, visszaigazolásra várva. Amennyiben nem történik meg a nyugtázás, ismét elküldi az adatokat. Ez addig ismétlődik, míg egy másik szenzor meg nem kapja az adatot, és a nyugtát vissza nem küldte erröl (Moss, et al., dátum nélk.).

Az eszköz a vezérlő parancsokat is rádión keresztül kapja meg. Három parancsot tud fogadni: mérés, törlés, és letöltés. A mérés esetén az elöre beállított időközönként mér. A törlés parancs esetén a falsh-t törli majd készenléti üzemmódba áll az eszköz. Ha a letöltő parancsot kapja meg, akkor a számítógéphez kapcsolt basestation eszközön keresztül a számítógépre küldi az adatokat, amelyek ott formázott struktúrában tárolódnak.

A TELOSB alacsony fogyasztású vezeték nélküli szenzor modul támogatja az IEEE 802.15.4/ZigBee vezeték nélküli kommunikációs szabványt, melynek segítségével az alacsony adatátviteli sebességet megvalósítja. A rádió modul 250 kbps adatátvitelre képes, 
melyet 2,4 GHz-es ISM sávban biztosítja. A rádióhoz tartozó antenna az alaplapra van integrálva, melynek hatótávolsága barlangban elérheti a 15 métert is. A vezérlésről egy 8 MHz-es MSP 430-as mikroprocesszor gondoskodik, mely 10 kB RAM-mal rendelkezik. Az eszközben gyárilag többféle érzékelő van beépítve. Található rajta látható és infravörös fényszenzor, továbbá egy hőmérséklet és páratartalom érzékelő szenzor. Az adatok tárolására 1 Mbyte flash memória áll rendelkezésünkre. A ki- és bemeneti perifériák: egy darab nyomógomb és 3 darab Led (CROSSBOW, 2004).

6. táblázat A vezeték nélküli szenzorok összehasonlítása, a TelosB (CROSSBOW, 2004)

fejlesztett verziója és az UC Mote Mini (Unicomp, 2011)

\section{TelosB}

Eszközök

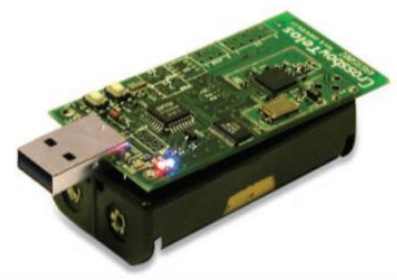

UC Mote Mini

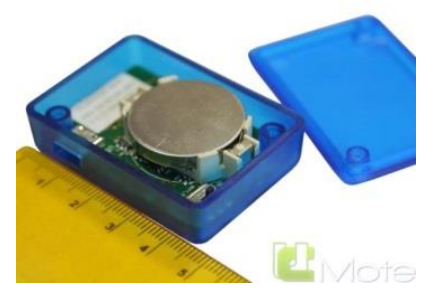

\begin{tabular}{lll}
\hline $\begin{array}{l}\text { Álatlános } \\
\text { tulajdonságok }\end{array}$ & $\begin{array}{l}\text { Olcsó, alacsony fogyasztás, kis méret } \\
\text { Nyílt forrású operációs rendszer (TinyOS) vezeték nélküli }\end{array}$ \\
\hline Hőmérsékelt & $\begin{array}{l}\text { Felbontása } \pm 0,01{ }^{\circ} \mathrm{C} \\
\text { Pontossága } \pm 0,5^{\circ} \mathrm{C}\end{array}$ & $\begin{array}{l}\text { Felbontása } \pm 0,01{ }^{\circ} \mathrm{C} \\
\text { Pontossága } \pm 0,3{ }^{\circ} \mathrm{C}\end{array}$ \\
\hline Páratartalom & $\begin{array}{l}\text { Felbontása } \pm 0,03 \% \\
\text { Pontossága } \pm 3,5 \%\end{array}$ & $\begin{array}{l}\text { Felbontása } \pm 0,04 \% \\
\text { Pontossága } \pm 2,0 \%\end{array}$ \\
\hline Légnyomás & - & $\begin{array}{l}\text { Szenzor: MS5607-02BA03 } \\
-20{ }^{\circ} \mathrm{C} \text { és } 85{ }^{\circ} \mathrm{C} \text { közötti tartományban, }\end{array}$ \\
\hline Flash Memory & $1 \mathrm{M}$ bytes & $\begin{array}{l}300 \text { és } 1100 \text { mbar között }-2.5-+2.5 \mathrm{mbar} \\
\text { hibahatár }\end{array}$ \\
\hline $\begin{array}{l}\text { Rádió } \\
\text { kommunikáció }\end{array}$ & $100 \mathrm{~m}$ & $2 \mathrm{M}$ bytes \\
\hline Processor & $8 \mathrm{MHz}$ & $400 \mathrm{~m}$ \\
\hline Elem & $2 \mathrm{X} \mathrm{AA} \mathrm{elem}$ & $16 \mathrm{MHz}$ \\
\hline Méret (mm) & $65 \times 31 \times 16$ & $\mathrm{CR} 2450$ elem \\
\hline User Interface & USB IEEE802.15.4/ZigBee & Micro USB IEEE802.15.4/ZigBee \\
\hline
\end{tabular}

A felprogramozás USB-n keresztül lehetséges, melyet az adatok kinyerésére is használhatunk. Az eszközön található még két csatlakozó felület, mellyel további szenzorokat és perifériákat tudunk csatlakoztatni. Az eszköz operációs rendszere a nyílt 
forráskódú TinyOS, melynek segítségével lehet felprogramozni az eszközt. Az áramellátásról 2 db LR6-os elem gondoskodik (Muladi, et al., 2012)

A TelosB müszer segítségével végeztem előzetes méréseket kisebb barlangokban 2010-2011 között. Majd lehetőségem nyílt az UC Mote Mini szenzorokból - melyek a TelosB eszköz továbbfejlesztett verziói - egy nagyobb müszerpark igénybe vételére.

Az UC Mote rádió modulja - mely a IEEE802.15.4/ZigBee szabványt használja $250 \mathrm{kbps}$ adatátvitelre képes, melyet 2,4GHz-es ISM sávban biztosít. A vezérlésről egy 16 MHz-es Atmel ATmega128RFA1-as mikroprocesszor gondoskodik, mely 128kB RAMmal rendelkezik (6. táblázat).

Az eszközben gyárilag többféle érzékelő van beépítve, az SHT21-es szenzor tudja mérni a hőmérsékletet és a páratartalmat, a Sensor MS5607-02BA03 rögzítjük a légnyomás adatokat (Muladi, et al., 2012). Az SHT21-es hőmérséklet szenzor felbontása $\pm 0,01{ }^{\circ} \mathrm{C}$, pontossága $\pm 0,3{ }^{\circ} \mathrm{C}$. A müszer SHT21 páratartalom érzékelőjének felbontása $\pm 0,04 \%$, RH és a pontossága $\pm 2,0 \%$ RH (Sensiron, 2011a). A müszer dobozolása Hammond 1551-es dobozban történt, melyet specializáltunk, a SHT21-es szenzorra helyezett Filter Cap segítségével. A Filter Cap egy olyan membránnal van ellátva, hogy IP67-es szabványnak megfelel, így védi a SHT21-es szenzort, ugyanakkor a chipet nem akadályozz a mérésben, minden apró rezdülésre reagál (Sensiron, 2011b).

7. táblázat A UCMote Miniből kinyert nyersadatok

\begin{tabular}{llllll}
\hline ID & Temp & Humidity & Time & Pressure & Temp2 \\
\hline 1 & 26196 & 30968 & 6706425 & 101695 & 8360922 \\
\hline 2 & 26476 & 29536 & 6765740 & 101692 & 8385340 \\
\hline 3 & 26072 & 31036 & 7687340 & 101703 & 8358120 \\
\hline 4 & 26264 & 30580 & 8608940 & 101689 & 8373566 \\
\hline 5 & 26116 & 31184 & 9530540 & 101669 & 8361142 \\
\hline 6 & 25980 & 31176 & 10452140 & 101670 & 8350432 \\
\hline 7 & 25956 & 31204 & 11373740 & 101663 & 8348590 \\
\hline
\end{tabular}

A UC Mote mote-okon található egy kapcsoló, mely segítségével az áramellátás módja választható ki, hogy akkumulátorról, vagy elemröl kívánjuk müködtetni. Az áramellátásról LIR2450akkumlátor, vagy CR2450 elem gondoskodik. Kiadható parancsok mérés adott pillanatban, letöltés, törlés (Mucsi, et al., 2014). 
A vizsgálatunk esetében 10 percenkénti adatrögzítéssel mértünk, és akár 3 hónapig is tudtuk használni anélkül, hogy elemet kellett volna cserélni a szenzorokban. Az adatok tárolására 2 Mbyte flash memória áll rendelkezésünkre. (Sensiron, 2011a).

A barlangi mikroklíma vizsgálat során minden vizsgált barlangban minimum 9 szenzort helyeztünk el, ezzel párhuzamosan egy szenzor mindig a barlangok bejáratának közvetlen közelében volt. Ezek a müszerek 10 percenként rögzítették a hömérséklet és páratartalom adatokat, valamint a müszerek közül minimum 3 db légnyomás érzékelővel ellátott szenzort is helyeztünk a barlangba.

Az adatok kiszámításához szükséges képletek (1. egyenlet), melyek a müszer datasheetjében (Sensiron, 2011a) találhatók, a megfelelő változók behelyettesítése után (7. táblázat) értelmezhető adatokat szolgáltatnak, ahol a hőmérséklet ${ }^{\circ} \mathrm{C}$-ban, a páratartalom \%-ban, a légnyomás hPa mértékegységben értendő (8. táblázat).

$$
\begin{gathered}
\mathrm{T}=-46,85+175,72 * \mathrm{Temp} / 2^{16} \\
\mathrm{RH}=-6+125 * \text { Humidity } / 2^{16} \\
\mathrm{P}=\text { Pressure } / 100
\end{gathered}
$$

1. egyenlet A nyersadatokhoz szükséges képletek, melyekkel megkaphatjuk a hőmérséklet (T),

\begin{tabular}{|c|c|c|c|c|c|c|c|c|}
\hline ID & Temp & Humidity & Time & Pressure & Temp2 & $\begin{array}{l}3040 \\
\text { höm }\end{array}$ & $\begin{array}{l}3040 \\
\text { pára }\end{array}$ & $\begin{array}{l}3040 \\
\text { légnyomás }\end{array}$ \\
\hline 1 & 26196 & 30968 & 6706425 & 101695 & 8360922 & 23,38 & 53,06 & 1016,95 \\
\hline 2 & 26476 & 29536 & 6765740 & 101692 & 8385340 & 24,13 & 50,33 & 1016,92 \\
\hline 3 & 26072 & 31036 & 7687340 & 101703 & 8358120 & 23,05 & 53,19 & 1017,03 \\
\hline 4 & 26264 & 30580 & 8608940 & 101689 & 8373566 & 23,57 & 52,32 & 1016,89 \\
\hline 5 & 26116 & 31184 & 9530540 & 101669 & 8361142 & 23,17 & 53,47 & 1016,69 \\
\hline 6 & 25980 & 31176 & 10452140 & 101670 & 8350432 & 22,80 & 53,46 & 1016,7 \\
\hline 7 & 25956 & 31204 & 11373740 & 101663 & 8348590 & 22,74 & 53,51 & 1016,63 \\
\hline
\end{tabular}
páratartalom (RH) és légnyomás adatokat $(\mathrm{P})$ (Sensiron, 2011a)

8. táblázat Példa a nyersadatok átszámítására

Az adatok kiszámítása után a szenzorok kalibrációja a következő lépés. Minden mérés előtt a szenzorokat egy zárható dobozbam helyeztem el addig, amíg barlangi kihelyezésük nem történt meg. A müszereket 1-2 nappal a telepítés előtt már elindítottam és leellenőriztem, hogy müködnek-e, majd elhelyeztem a légmentes dobozban. Elsőként mindig ezeket az adatokat, vettem figyelembe a kiértékeléskor (21. ábra), mivel a 
müszereket akkor azonos helyen azonos hatások érték, így az egymástól való eltérésüket meg lehetett állapítani.
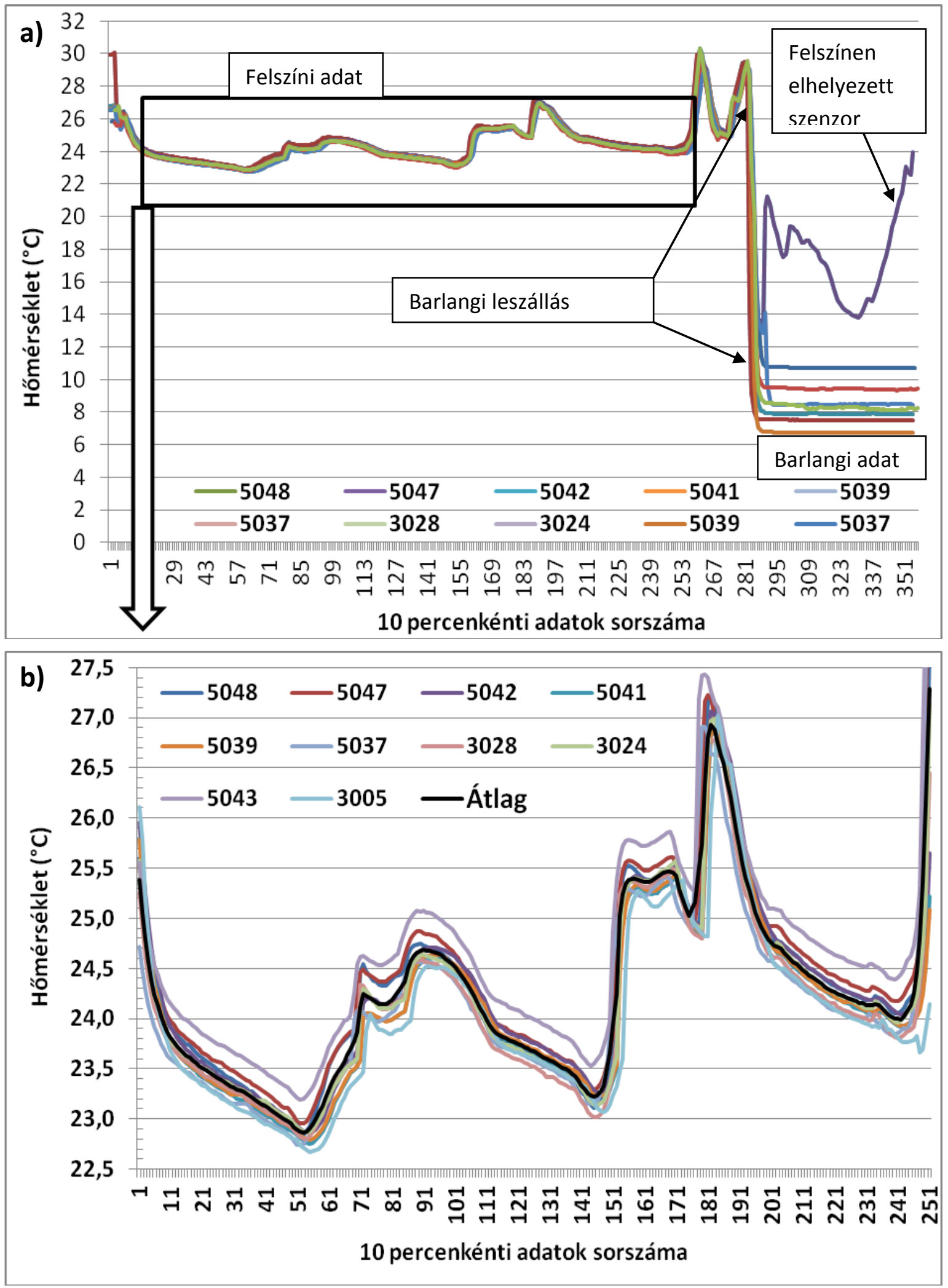

21. ábra Az UC Mote Mini szenzorok mérési pontossága (a,b) 


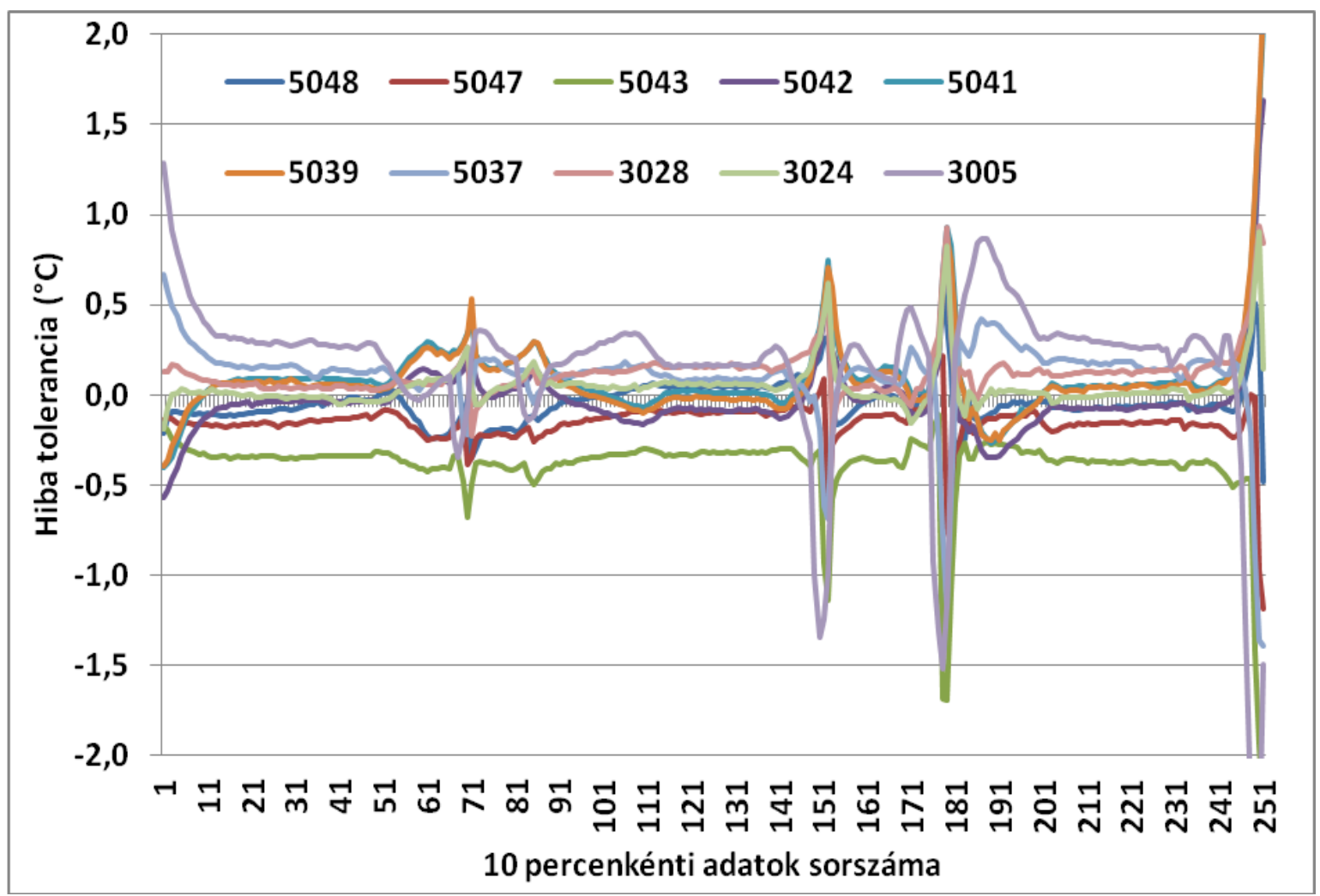

22. ábra Az UC Mote Mini szenzorok hibatoleranciája

9. táblázat A szenzorokhoz tartozó kalibrációs konstans

\begin{tabular}{ccccccccccc}
\hline $\begin{array}{c}\text { Szenzor } \\
\text { azonosító }\end{array}$ & 5048 & 5047 & 5043 & 5042 & 5041 & 5039 & 5037 & 3028 & 3024 & 3005 \\
\hline $\begin{array}{c}\text { Kalibrációs } \\
\text { konstans }\end{array}$ & $-0,04$ & $-0,16$ & $-0,39$ & $-0,03$ & 0,10 & 0,08 & 0,11 & 0,12 & 0,04 & 0,17 \\
\hline
\end{tabular}

Az átlagtól vett eltérés alapján (21. ábra) megállapítottam a kalibrációs konstanst (9. táblázat), és azzal módosítottam az adatsort. A hiba tolerancia alapján látható (22. ábra), hogy a hirtelen $2-3{ }^{\circ} \mathrm{C}$-os hőmérséklet-változások esetében lesz egy mérési adat, amelynek a hibatoleranciája $1-(-1)^{\circ} \mathrm{C}$ közé esik. A felszínen rögzített adatok alapján az időpontokat is korrigálni tudtam, mivel nem tudtam minden müszert egyszerre elindítani, így minimális időbeli különbséggel mértek, de amikor a barlangi leszállás megtörtént, az összes műszer felveszi a barlang hőmérsékletét. Ezt a hirtelen változást kihasználván időben is egyesíteni tudtam az adatokat, hiszen minden müszer egyszerre került a balrangba.

A hőmérséklet adatok alapján láthatóvá vált, hogy a minimális hőmérsékletváltozásokra is jól reagál a müszer. A hőmérséklet-változásokkal összhangban a páratartalom adatokon is megfigyelhetök a trendek, illetve páratartalom-változások, ugyan abban az időben, mint a hömérsékletnél (23. ábra). 


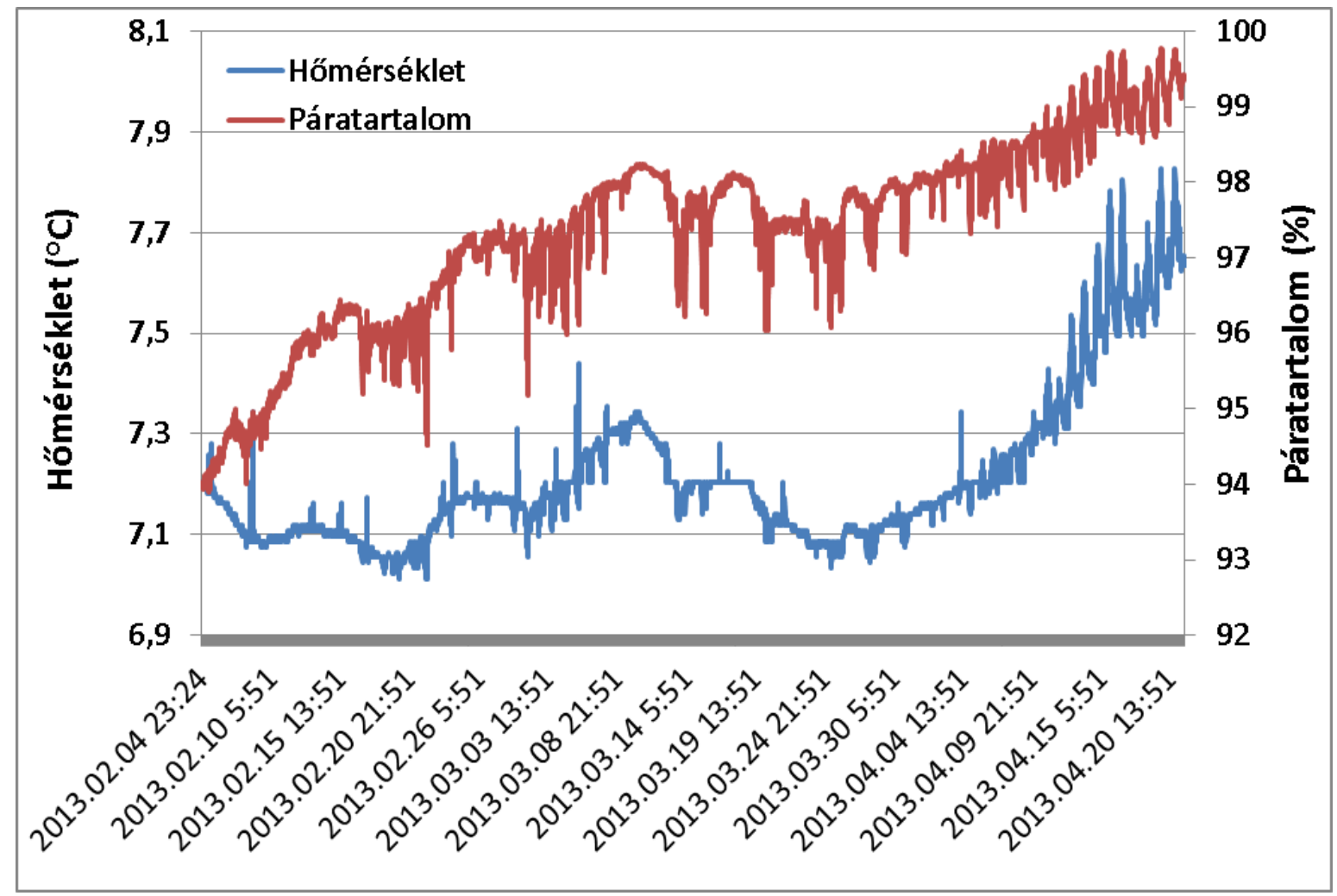

23. ábra Az UC Mini Mote szenzorral rögzített hőmérséklet és páratartalom adatok

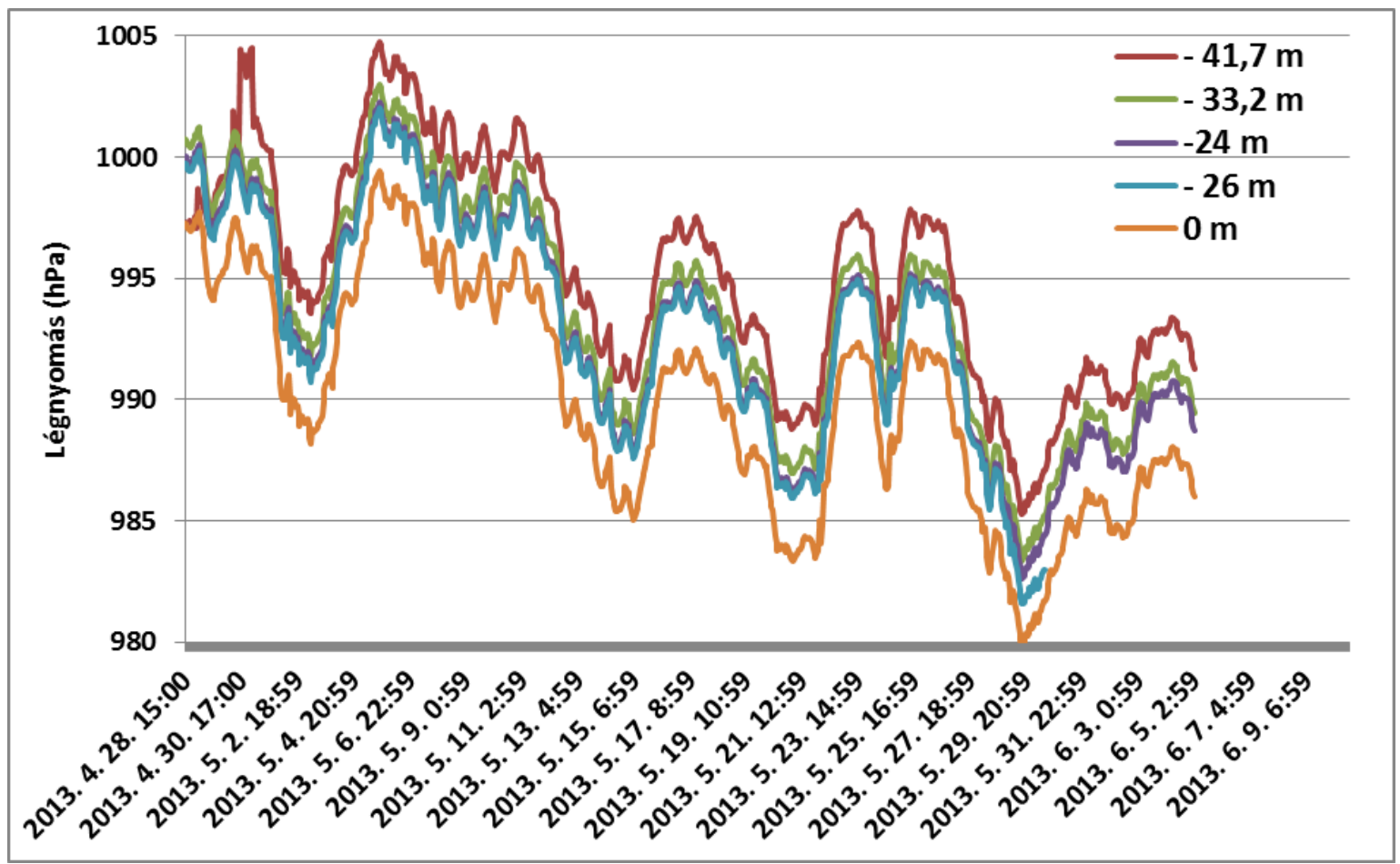

24. ábra Az UC Mini Mote szenzorral rögzített hőmérséklet és páratartalom adatok

A légnyomásmérés esetében a barlangon belül ugyanazok a folyamatok érzékelhetők, mint a felszínen. Egy példa méréssorozat alapján látható, hogy a barlang 
járatainak mélyülésével növekszik a légnyomás, tekintve a légréteg vastagságának növekedését (24. ábra).

A felszíni adatokat minden esetben összehasonlítottam a legközelebbi meteorológiai állomás adataival a Hajnóczy-barlangnál rögzítetteket a Szentléleki meteorológiai állomás adataival. A Pál-völgyi-barlang, Harcsaszájú-barlang és Hideg-lyuk adatait a Köfejtőben található meteorológiai állomás paramétereivel vizsgáltam. A Trió-barlangnál, pedig a Pécsi meteorológiai állomás (WMO INDEX: 12942) adatait használtam.

A radonkoncentrációra vonatkozóan RSFV wide range típusú müszer segítségével néhány kiegészítő mérést végeztem Ez a típusú radon mérő nem a radonszint változást mutatja, csak a balrangban töltött napok száma alapján egy kumulált radonszintet tud meghatározni.

A barlangok térbeli elemzésére a Polygon programot használtam, és az alapján tudtam meghatározni, hogy mely szakaszra helyeztem el a hőmérsékletmérő müszereket. A Polygon programban határoztam meg a müszerek bejárattól számított térbeli távolságát. Körültekintően kellett eljárnom ennél a számításnál, mivel a függőleges aknák esetében nem tudta a program kiszámítani a két pont közötti távolságot.

Az mintaterület ábráit ArcGIS program segítségével készítettem el. A barlang rajzolt alaprajzi térképit georeferálással igazítottam a poligon rajzhoz, így vetületi rendszerben tudtam el helyezni. Miután a rajzolt képeket térben elhelyeztem lehetőségem nyílt a Therion programban egy áttekintő 3D-s modell elkészítésére, ahol a barlangok járatainak és termeinek nagyságáról kaphatunk információt. Ehhez a modellhez a barlang poligonjára és alaprajzi térképre volt szükség, majd a keresztszelvényekkel lehetett pontosítani a térrajzot.

Azoknál a barlangoknál, ahol nem ált rendelkezésemre megfelelő adat a 3D-s modell elkészítéséhez, ott a barlangok alaprajzi térképén készítettem a barlangon belüli hőmérséklet eloszlását. Ehhez az interpolációhoz ArcGIS Spline with Barrier funkcióját használtam, mely alkalmas arra, hogy a barlang járatain belül végezze el a számításokat (Price 2014). 


\section{Eredmények}

A kutatás kezdeti időszakában a müszerek tesztelése zajlott laborkörülmények között, ahol bebizonyosodott, hogy megfelelö kalibráció esetén a müszerek közötti $0,3{ }^{\circ} \mathrm{C}$-os különbség kiküszöbölhető. Minden mérés sorozat előtt és után egy légmentesen lezárt dobozban szállítottam a barlangig a szenzorokat, így tudtam, hogy adott mérésnél szenzoronként milyen eltérésre számíthatok. A barlangi mérések megkezdése előtt 2011 decemberében a bükki Hajnóczy-barlangban teszteltem a rendszert. Ezt követően 10 percenkénti adatokkal rendelkezem a barlangról. Ezután folyamatosan bővült a vizsgálati helyszínek sora, 2012. áprilisától Hideg-lyuk barlanggal, 2013. áprilisától a Pál-völgyi barlanggal, majd időszakos vizsgálatok történtek a Trió-barlangban, és Harcsaszájú-barlangban is. Egyre szélesebb vizsgálati kör révén, egyre több kérdés merült fel, hogy egyes barlangoknál milyen hatások érvényesülnek.

A kérdések, amikre keresem a választ:

- A barlangon belül hogyan rétegződik a levegö hőmérséklete?

- Hogyan lehet egyszerü elemzéssel lehatárolni a hülési, örvénylési és melegedési szakaszokat?

- A hosszú távú mérések során mikor történik, és milyen tényezőktől függ a tavaszi és őszi légáramlás fordulása?

- A barlangban túrázó vagy kutató csoportok létszáma hogyan befolyásolja a léghőmérsékletet? Ezt továbbgondolva mennyi idő a megnövekedett hőmérsékletnek a lecsengése?

\subsection{A barlangok vizsgált pontjainak bemutatása a tengerszint feletti magasság és léghőmérséklet tükrében}

\subsubsection{Az egy éven át tartó megfigyelések}

A barlangok morfológiai tulajdonságai nagyon eltérőek, így a járatok vertikális tagoltsága is különböző. A járatok különböző tengerszint feletti magasságából adódóan más-más hőmérsékleti szinten rétegződik a levegő.

$\mathrm{Az}$ adatok könnyebb kezelhetősége érdekében a 10 perces adatokat 1 óránként átlagoltam az éves áttekintés során minden barlang esetében. Ezután a barlangi vizsgálati helyszínekre kiszámítottam a vizsgált időszak minimum, maximum és átlagos adatait, melyeket a diagrammon ábrázoltam. Azokban az esetekben, ahol adathiánnyal kellett 
számolnom (mérési adatsor fele hiányos) ott szürke színnel jelenik meg az átlag értéke, ahol viszont megfelelő mennyiségü adat állt rendelkezésemre, ott piros színnel jelöltem az átlaghőmérséklet értéket.

\section{Hajnóczy-barlang vizsgálati pontjainak tengerszint feletti magassága és hőmérséklete}

A Hajnóczy-barlang esetében a 2012.03.11.-2013.04.10. közötti időszakot választottam ki az egy éves vizsgálatra. Ebben az időszakban szenzoronként átlagosan $n=8747 \mathrm{db}$ órára átlagolt adatot vizsgálok. A barlang vizsgált pontjainak (13.ábra) tengerszint feletti magasságát lineárisan ábrázolva (25. ábra) láthatóvá válik, hogy a bejárat 457 m-en nyílik, ezután a Lapos-teremig folyamatosan mélyül a barlang 29 m-rel, majd innen az Óriásteremig 476 m-ig emelkednek a járatok. Az átlaghőmérséklet adatokon láthatóvá válik, hogy a 19 m-es szintkülönbség esetén $5,1^{\circ} \mathrm{C}$-os volt a hőmérséklet különbség (26. ábra).

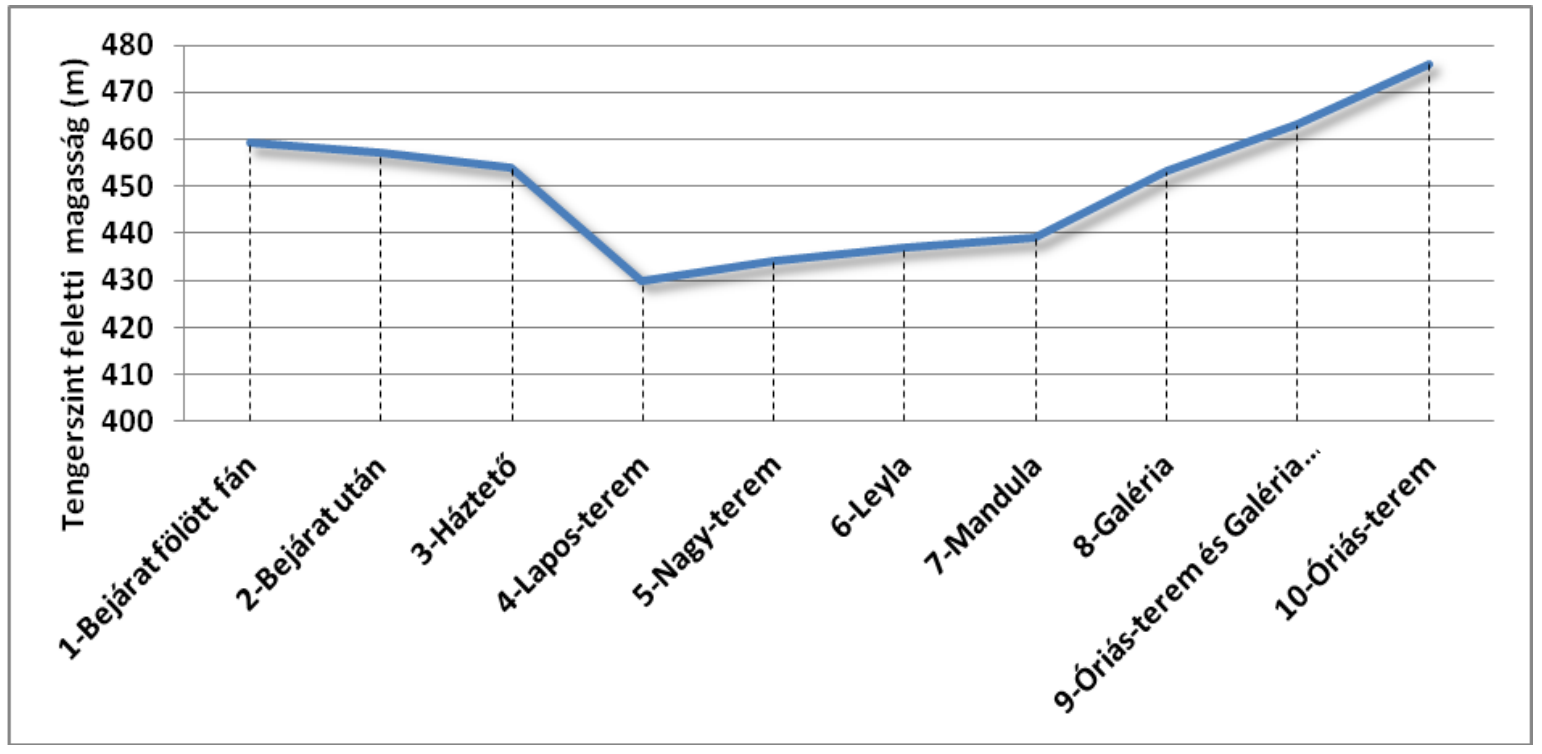

25. ábra A Hajnóczy-barlang vizsgált pontjainak tengerszint feletti magassága

A vizsgált időszakban a felszínen elhelyezett müszer $-6,1-29,0{ }^{\circ} \mathrm{C}$ közötti hőmérsékletváltozást rögzített, mely a barlang bejáratától néhány méterre volt. Az átlagos hőmérséklet ebben az egy éves időszakban $11,2{ }^{\circ} \mathrm{C}$ volt. Ezt az adatot leellenőriztem a szentléleki meteorológiai állomás adataival, mely a következő volt: min.: $-6,2{ }^{\circ} \mathrm{C}$, max.: $29,4{ }^{\circ} \mathrm{C}$, átlag: $11,1^{\circ} \mathrm{C}$. A Bejárat utáni szenzor (a vaslemezből készült ajtó után volt 2 méterre elhelyezve, az ajtó zárt csak denevérnyílás található rajta) a téli, sürübb hideg levegö 
hatására átlagosan $5,7^{\circ} \mathrm{C}$-ot mért, míg az Óriás-teremben elhelyezett müszer $10,8{ }^{\circ} \mathrm{C}$-ot rögzített. A Háztetőnél $7,5^{\circ} \mathrm{C}$ volt átlagosan, és habár a Lapos-terem $24 \mathrm{~m}$-rel mélyebben helyezkedik el, mégis átlagosan $0,5^{\circ} \mathrm{C}$-al volt melegebb, köszönhetően annak, hogy a felszíni hatások itt már kevésbé érvényesülnek. A Nagy-terem - Leyla - Mandula vonala 434-437-439 tszf. magasságon helyezkedik el, és ekkora különbség hatására is $0,1{ }^{\circ} \mathrm{C}$ különbség látható az átlagos hőmérsékletükben. A Felső-Galéria és Mandula közötti $14 \mathrm{~m}$ szintkülönbség átlagosan $1^{\circ} \mathrm{C}$-os hőmérséklet különbséget eredményez. A Felső- Galéria Óriás-terem és Galéria között - Óriás-terem vonala 453-463-476 tszf. magasságai hatására 9,7-10,2-10,8 ${ }^{\circ} \mathrm{C}$ az átlagos hőmérséklet. Ezek alapján elmondható, hogy barlangi légkörzés esetén a levegö rétegzettségét tekintve a Hajnóczy-barlang vizsgált szakaszán a hömérséklet 2-3 m-enként $0,1^{\circ} \mathrm{C}$-kal változik.

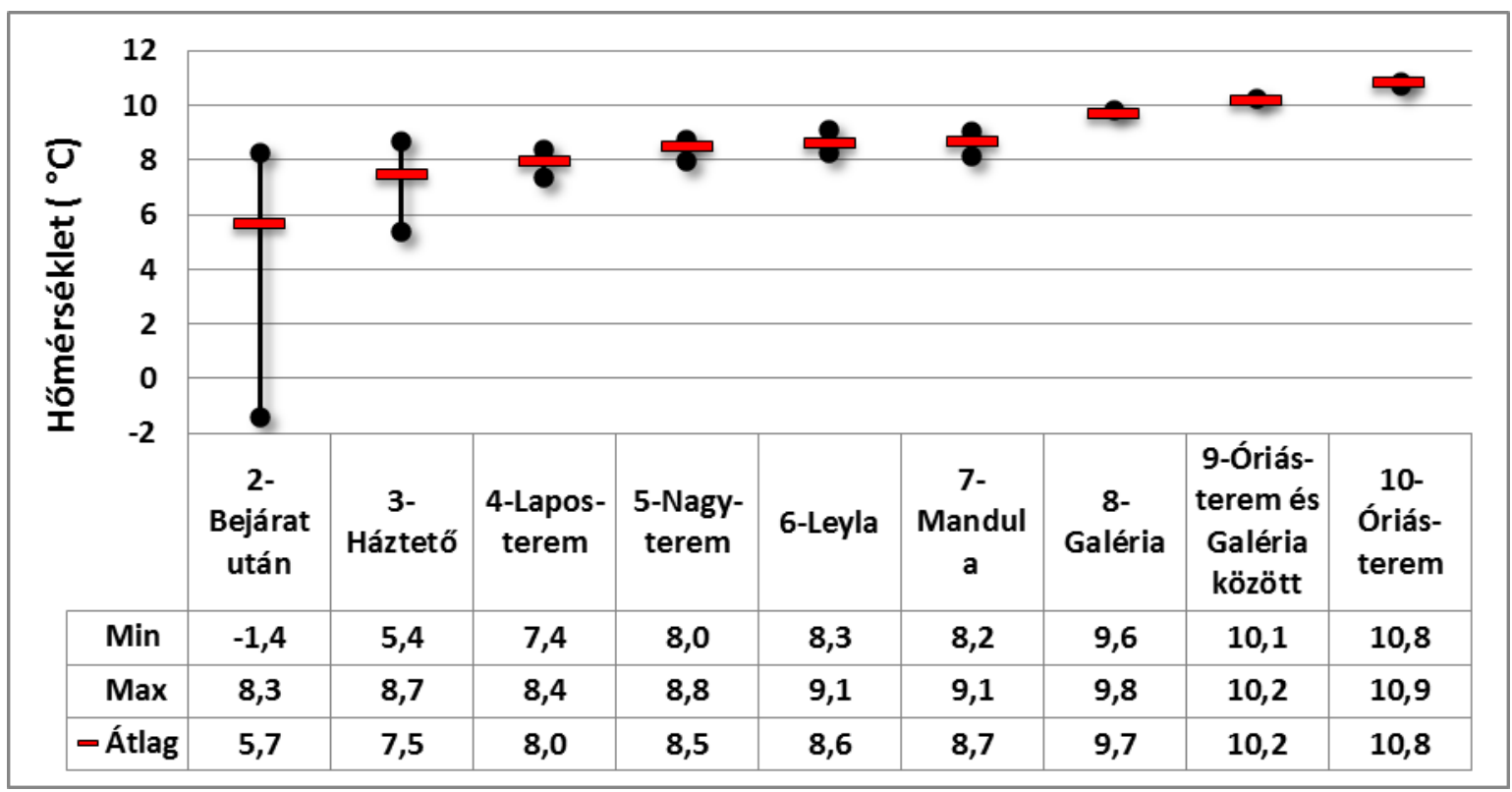

26. ábra A Hajnóczy-barlang vizsgált pontjainak alapstatisztikai értékei 2012.03.11-2013.04.10. között

\section{Hideg-lyuk vizsgálati pontjainak tengerszint feletti magassága és hőmérséklete}

A Hideg-lyuk esetében közel azonos periódust választottam ki, mint a Hajnóczy-barlang esetében, ez 2012.04.20-2013.12.07 között mért adatok. Ebben az időszakban n=13562 db órára átlagolt adattal dolgoztam. A Hideg-lyuk bejárata 197 m-en nyílik, ahol az erőteljes huzat figyelhető meg $(1,5-2 \mathrm{~m} / \mathrm{s})$ az év nagy részében. A másfél éves átlaghőmérséklet a barlang bejáratában $7,9{ }^{\circ} \mathrm{C}$ körül alakul. 
A Bányatámok rész az alsó bejárat, és a Gábor Áron aknabejárat között helyezkedik el, itt 12 m-rel mélyebben, mint a Bejáratnál (27. ábra), ezen a szakaszon $6,8{ }^{\circ} \mathrm{C}$ levegö oszlop uralja a járatot (28. ábra). A Rézágyú-terem 192 m-en helyezkedik el 7 m-rel magasabban a Bányatámokhoz képest, az átlagos hőmérséklet $8,4^{\circ} \mathrm{C}$. A Rézágyú-teremtől tovább haladva a Referencia-bivak és Medvecsapda vonalon folyamatosan mélyül a barlang 4, illetve 3 méterrel, az átlaghőmérséklet ezeken pontokon $7,9^{\circ} \mathrm{C}$ és $8,1^{\circ} \mathrm{C}$. A Referencia-bivaktól folyamatosan emelkedik, a Guillotine-Lépőcsavarok-Pecsétnyomószakaszon összesen 10 m-es vertikális emelkedés figyelhető meg. A Karácsony-teremnél 5 m-es szint csökkenés következik be a járatok futásvonalában. A hőmérsékletben a Referencia-bivaktól a Karácsony-teremig $7,9-10,7{ }^{\circ} \mathrm{C}$ közötti folyamatos emelkedés figyelhetö meg.

A Felszíni hatásokat figyelembe véve, látszódik az Alsó-Bejárati szakaszon, hogy nyáron erős a barlangból kifelé húzó légáramlat, mivel a felszínen mért maximális $40{ }^{\circ} \mathrm{C}$ nem módosította a barlang bejárati klímáját, az itt mérhető maximális hőmérséklet $10,5{ }^{\circ} \mathrm{C}$ volt. A felszíni hideg levegő ( $\min .-15,8^{\circ} \mathrm{C}$ ) viszont már módosította a bejárati környezet hőmérsékletét, az itt rögzített minimum érték $-4,1^{\circ} \mathrm{C}$. A bejárattól távolodva a $\Delta \mathrm{T}$ értéke egyre csökken, a Bányatámoknál $\Delta \mathrm{T}=4,4{ }^{\circ} \mathrm{C}$.

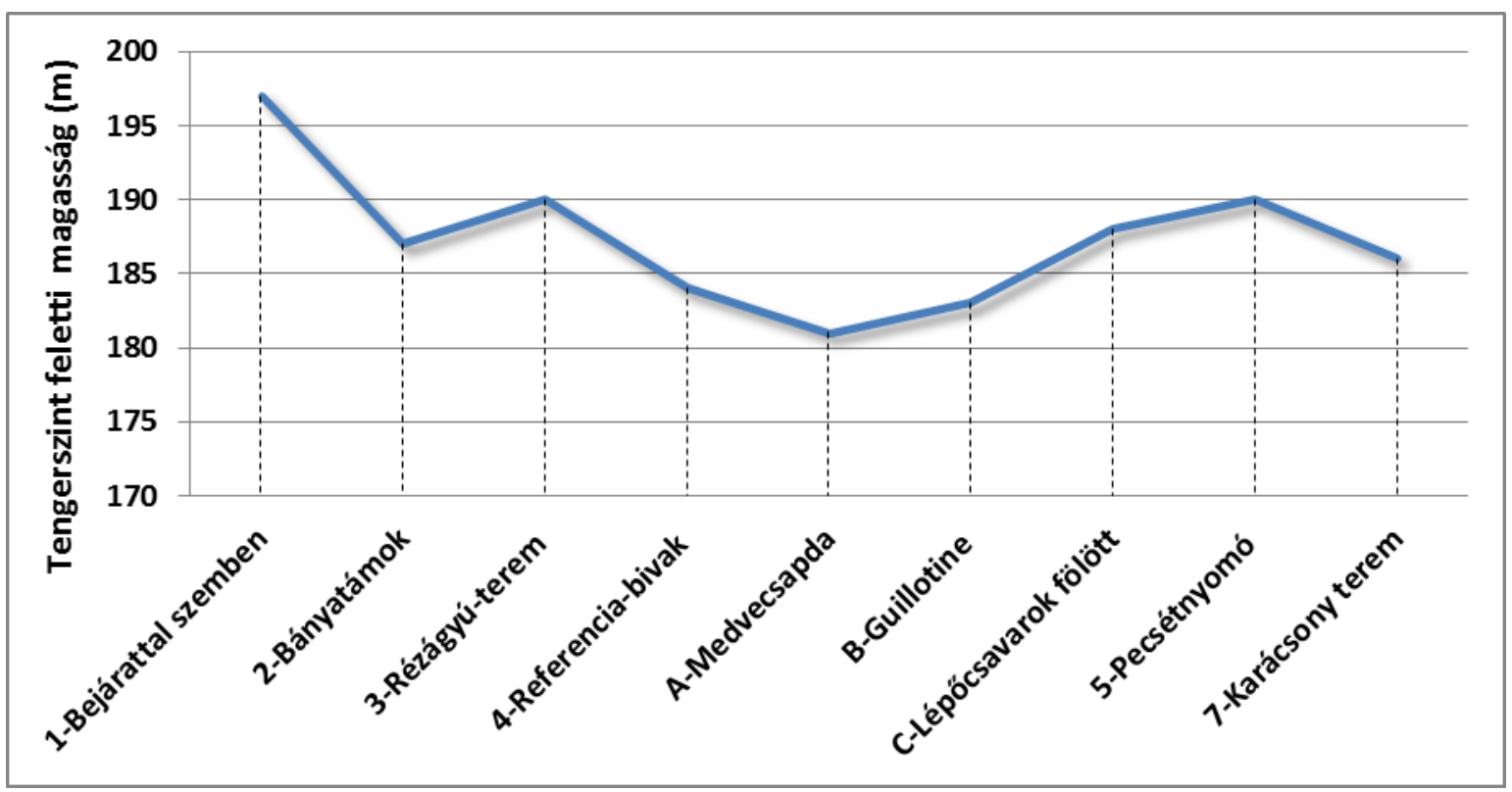

27. ábra A Hideg-lyuk vizsgált pontjainak tengerszint feletti magassága 


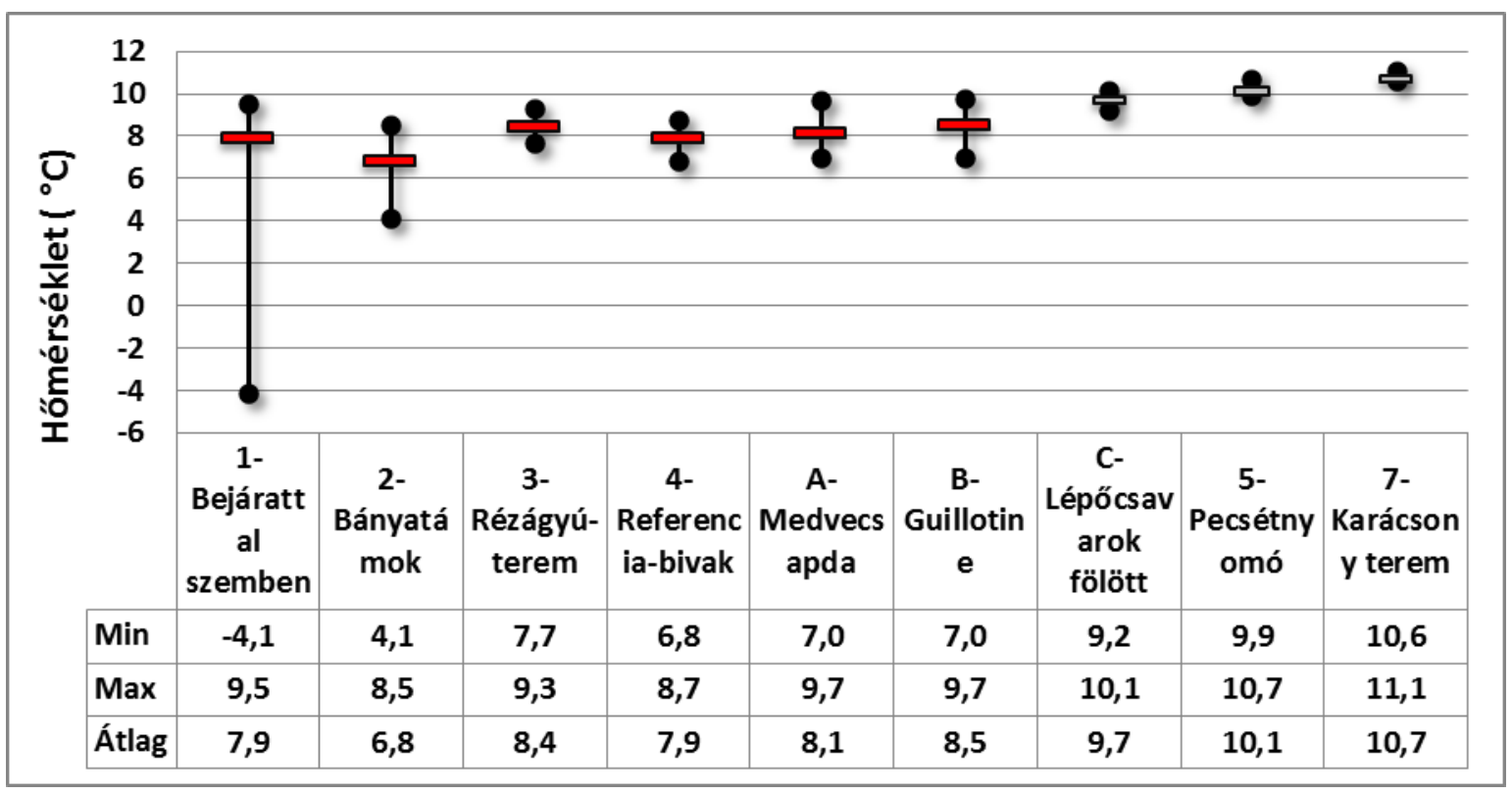

28. ábra A Hideg-lyuk vizsgált pontjainak alapstatisztikai értékei 2012.04.20-2013.12.07. között

\section{Pál-völgyi-barlang vizsgálati pontjainak tengerszint feletti magassága és hőmérséklete}

A Pál-völgyi-barlangban a vizsgálati időszak 2013.04.24-2014.04.27. között zajlott. Ez idő alatt $n=7130 \mathrm{db}$ órára átlagolt adaton végztem a vizsgálatot. A könnyebb áttekinthetőség érdekében az adatokat 4 részre bontottam.

A mintaterület ábrán (16. ábra) is látható, hogy az egymáshoz közel eső pontok, melyek felfüzhetők egy nyomvonalra, egy csoportot alkotnak.

1. csoport Nyomdászprés- Köhíd vonalán helyezkedett el,

2. csoport a Meseország - Ferde-terem közötti vonalon,

3. csoport a Pentacon-terem és környéke,

4. csoport a legbelső szakasz a Bekey-terem - Z-folyosó közötti szakasz volt.

A tengerszint feletti adatokon látszódik, hogy a négy csoport vizsgálati pontjai 60 méteres vertikális különbséggel, 140-200 m között helyezkednek el (29. ábra).

A bejárati szakaszban volt a legnagyobb adathiány, így az első csoport adatainak esetében csak egy hozzávetőleges átlagos hőmérsékletet tudok prezentálni (30. ábra). A Nyomdászprés és a Köhíd vonalán elhelyezett szenzorok átlaghőmérséklete $7,5-9,9{ }^{\circ} \mathrm{C}$ között alakul. 


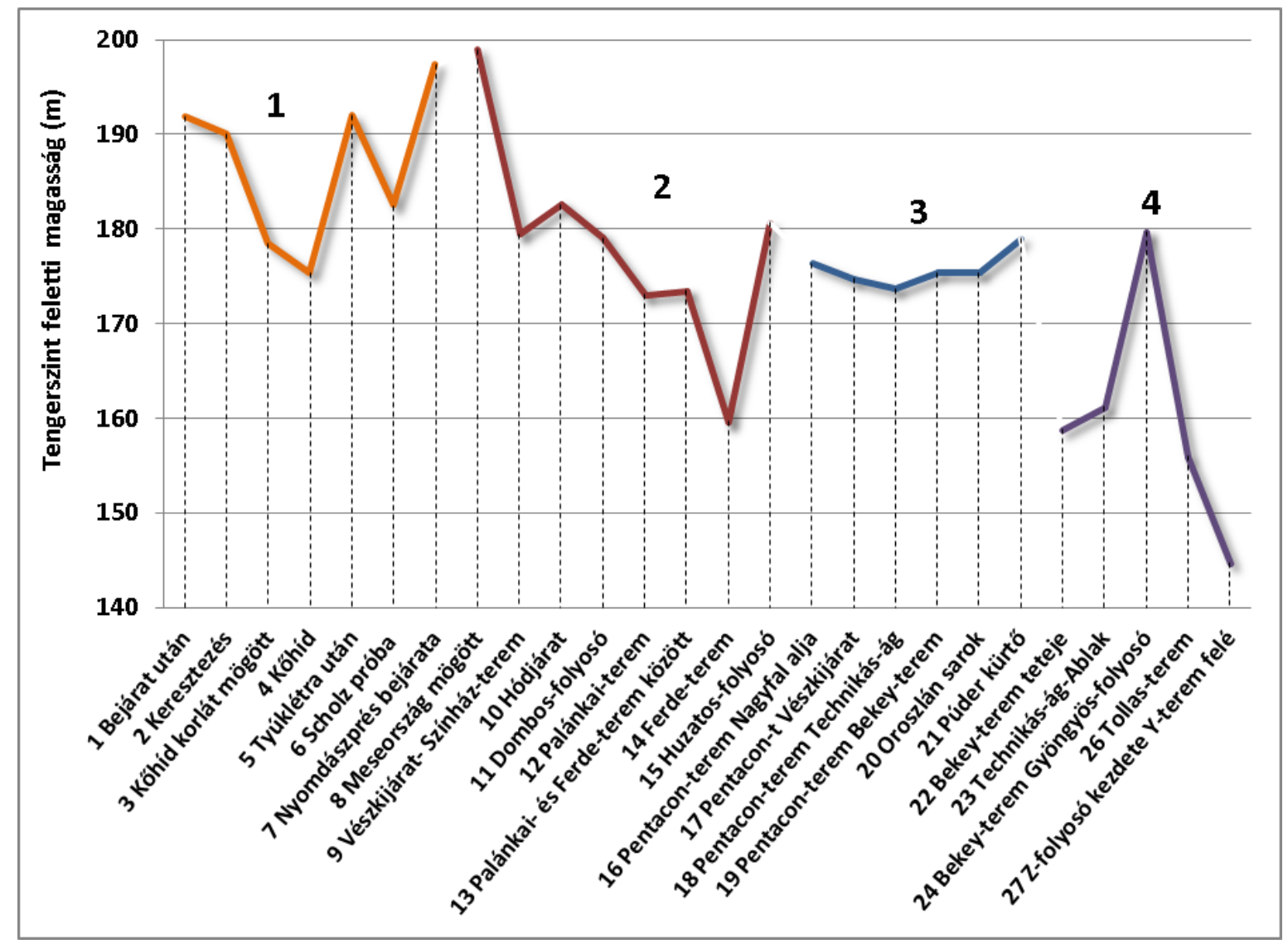

29. ábra A Pál-völgyi-barlang 4 csoportba osztott vizsgált pontjainak tengerszint feletti magassága

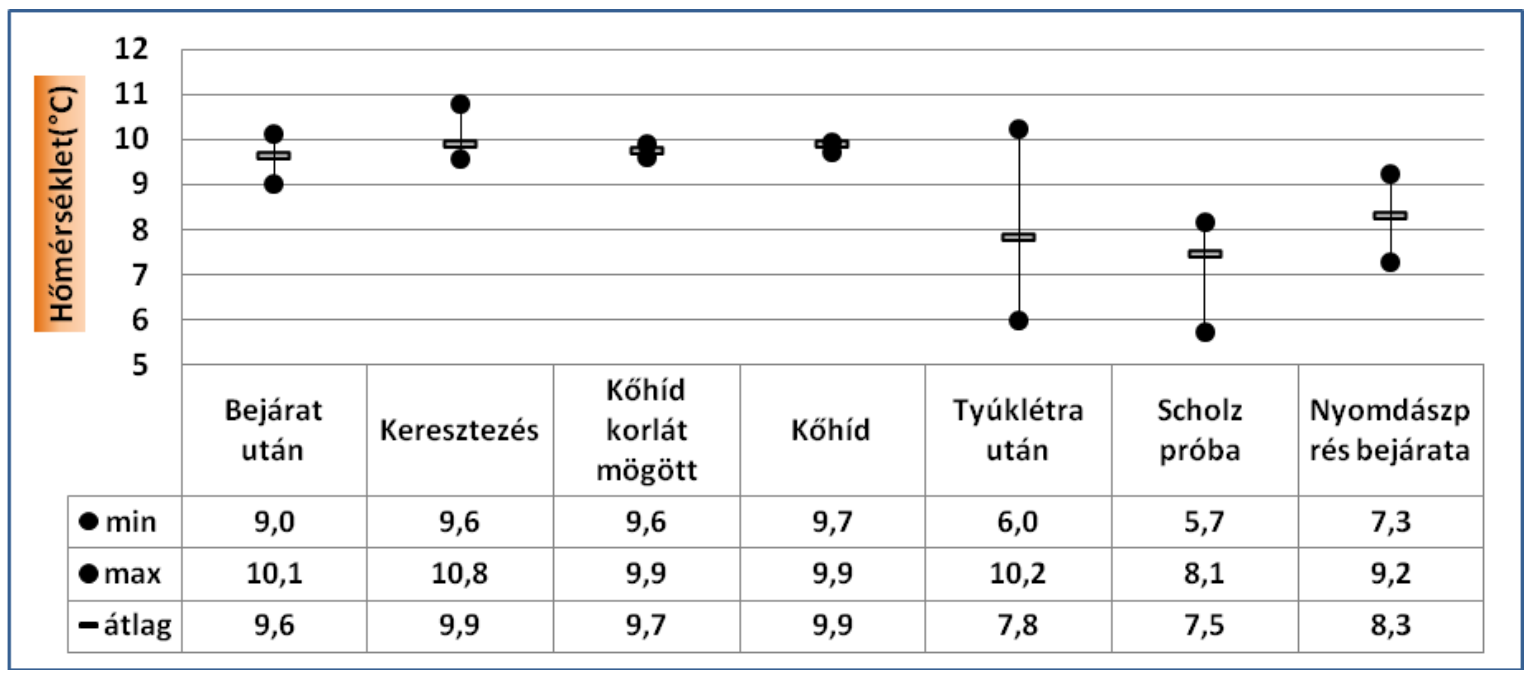

30. ábra A Pál-völgyi-barlangban az 1. csoport vizsgált pontjainak alapstatisztikai értékei 2013.04.24-2014.04.27.között

Adathiány miatt nem értékelhető, de a leghosszabb ideig müködő belső 3 szenzor alapján itt még egyértelműen a bejárati zónában vagyunk. 
A második csoport tengerszint feletti értékeinél a legnagyobb a tagoltság 159-199 m (29. ábra). Az átlagos hőmérséklet $8,7-10,3{ }^{\circ} \mathrm{C}$ között alakul (31. ábra). A Meseországban található a legmagasabban a vizsgálati pont, 199 m-en. Az átlagos hőmérséklet adatokon is látszódik, hogy ezen a járatszakaszon a legmagasabbak a hőmérséklet átlagosan $10,3{ }^{\circ} \mathrm{C}$. A Vészkijárat-Színházterem, a Hódjárat és a Huzatos-folyosó esetében 8,7-9 ${ }^{\circ} \mathrm{C}$ hőtartományban változik a hőmérséklet. A Dombos Folyosótól folyamatosan bentebb haladva a Palánkai-termen keresztül a Ferdeteremig folyamatosan növekszik a hőmérséklet 8,9-9,8 ${ }^{\circ} \mathrm{C}$-ig, annak ellenére, hogy itt a tengerszint feletti magasság 179 m-ről 159 m-re csökken (29. ábra). Ez is azt mutatja, hogy itt már a barlang hömérséklete érvényesül.

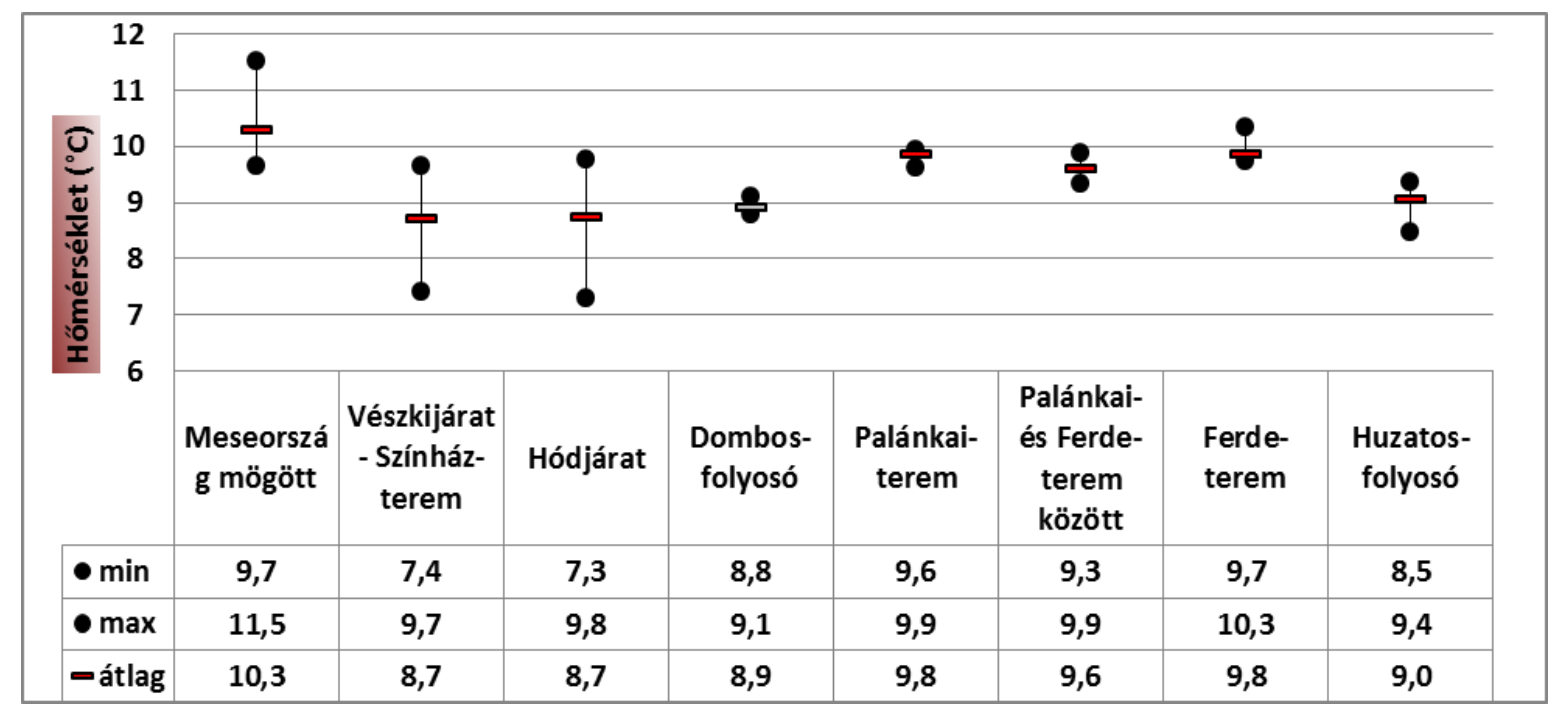

31. ábra A Pál-völgyi-barlangban az 2. csoport vizsgált pontjainak alapstatisztikai értékei 2013.04.24-2014.04.27.között

A harmadik csoport esetében a Pentacon-terem és környéke alkot egy csoportot, ahol az átlagos hömérséklet $9-10{ }^{\circ} \mathrm{C}$ között változik (32. ábra). A járatok magassága is kiegyenlített, mindössze $5 \mathrm{~m}$-es relieffel változik a terület $(174-179 \mathrm{~m})(29$. ábra). A Pentacon Vészkijárata, és a Púder-kürtő jobban kommunikálnak a felszínnel, itt 1-2,8 ${ }^{\circ} \mathrm{C}$ os a változás, míg a csoport többi tagjánál kisebb a változás $\left(0,3-0,5^{\circ} \mathrm{C}\right)$.

A negyedik csoport esetében a Bekey-terem és Z-folyosó közötti szakaszon is 9,3$9,9{ }^{\circ} \mathrm{C}$ közötti az átlagos hőmérséklet (33. ábra). A Bekey-terem tetején még változékony a hőmérséklet $8,4-9,8^{\circ} \mathrm{C}$ között mozog. A többi pontban is látható a hömérséklet éves ciklusa, de itt csak $0,3-0,5^{\circ} \mathrm{C}$ a változás. 


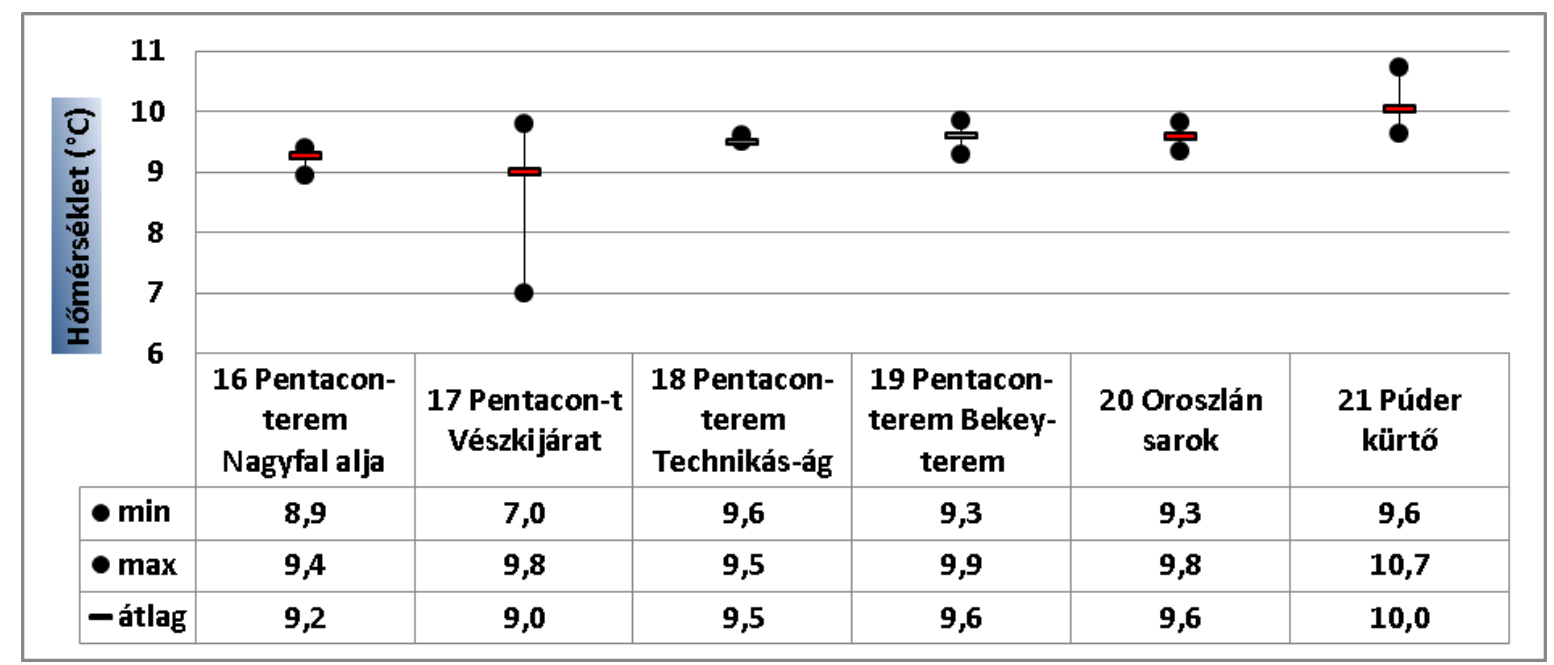

32. ábra A Pál-völgyi-barlangban az 3. csoport vizsgált pontjainak alapstatisztikai értékei 2013.04.-2014.04.27.között

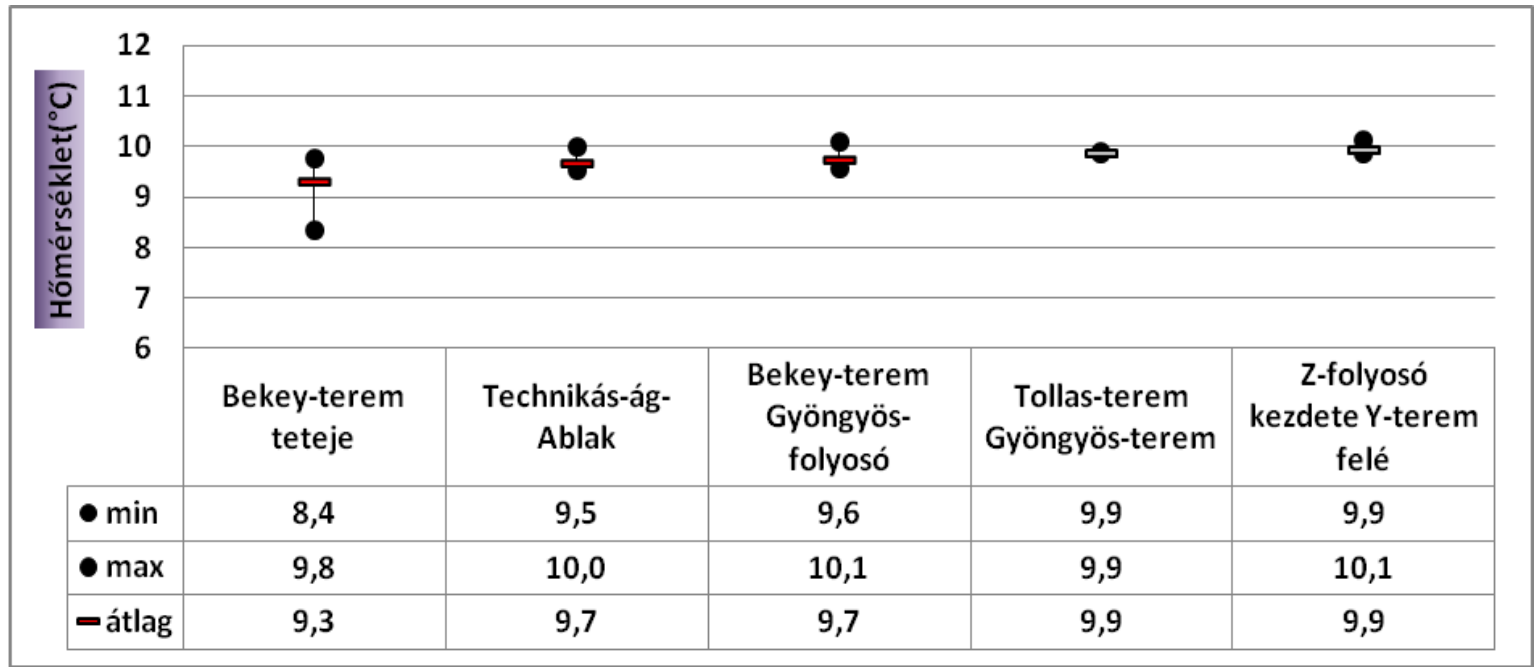

33. ábra A Pál-völgyi-barlangban az 4. csoport vizsgált pontjainak alapstatisztikai értékei 2013.04.24-2014.04.27.között

\subsubsection{Időszakos megfigyelések}

\section{Harcsaszájú-barlang vizsgálati pontjainak tengerszint feletti magassága és hőmérséklete}

Harcsaszájú-barlang esetében a 2013.04.24.-2013.06.05. közötti időszakot választottam ki a szezonális vizsgálat céljából. Ebben az időszakban szenzoronként átlagosan $n=3900 \mathrm{db}$ 10 percenkénti adatot vizsgálok. A vizsgált pontok (13.ábra) tengerszint feletti magassága alapján a barlang folyamatosan mélyül, a bejárat 218 m-en nyílik, és az utolsó vizsgált pont 165 m-es tszf. magasságban van (18-as pont, Tej bontás) (34. ábra). 


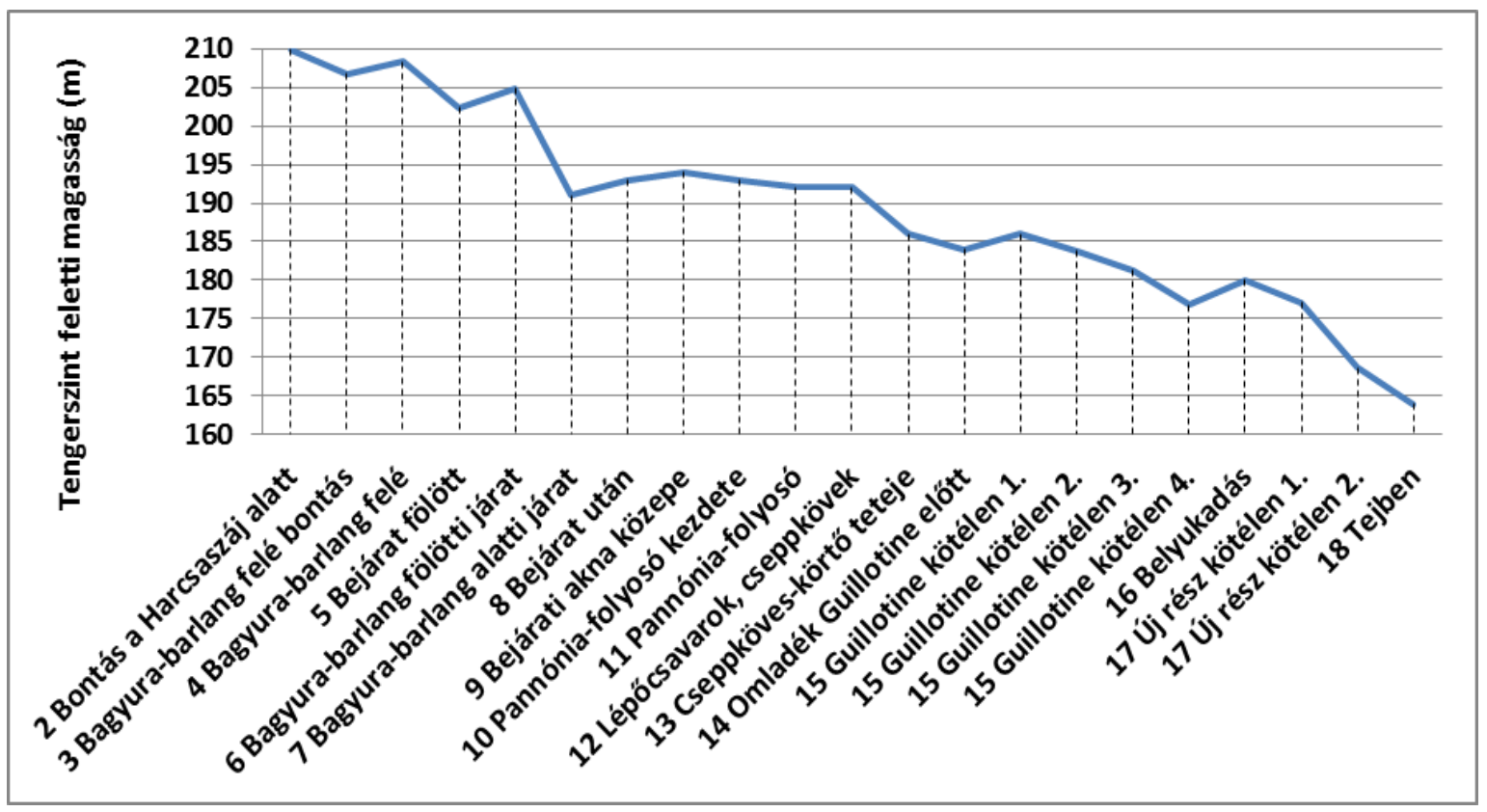

34. ábra A Harcsaszájú-barlang vizsgált pontjainak tengerszint feletti magassága

Az átlaghőmérséklet adatokon jól elkülönülnek a bejárat környéki bontásoknál, illetve a barlangi szakaszokon elhelyezett müszerek adatai (35. ábra). A kőfejtő bányászása során egy nagy barlangi termet találtak a vájárok, ez adja a Harcsaszáj különleges formáját. A vizsgálat során a bejárati előcsarnokot is körültekintően vizsgáltuk, az innen induló járatok, és bontási pontok feltérképezése céljából. A Bagyura-barlanggal való összeköttetés is ennél a bejárati szakasznál található, így a Bagyura-barlang járatai felé is vizsgálhattam az átszellőzöttséget.

A vizsgált időszakban a felszíni hőmérséklet átlaga $15,4{ }^{\circ} \mathrm{C}$ volt, nappal $24,3{ }^{\circ} \mathrm{C}$-ig melegedett fel a hőmérséklet, míg éjszaka $9,5^{\circ} \mathrm{C}$ volt a leghüvösebb a barlang bejáratánál. Az Előcsarnokból nyíló járatokban elhelyezett szenzorok (18. ábra) adatai alapján látható, hogy itt a felszíni hatások még erőteljesebben módosítják a léghőmérsékletet. A tengerszintfeletti magasság 210-190 m között alakul a hömérséklet itt 6,910 C között van. A bejárat utáni szakaszon az átlagos hőmérséklet $7,2-9,6{ }^{\circ} \mathrm{C}$ között alakul itt a járatok magassága fokozatosan mélyül az egyre bentebbi szakaszon (191-186 m). A Guillotine omladék utáni szakaszon a járatok magassága 184-176 m között változik az átlagos hőmérséklet ezen a szakaszon már melegebb 8,6-9 C. A legmelegebb szakasz a vizsgált terület legalacsonyabb szakaszán található, itt 177-164 m-en a hömérséklet 10,2-10,9 ${ }^{\circ} \mathrm{C}$. 


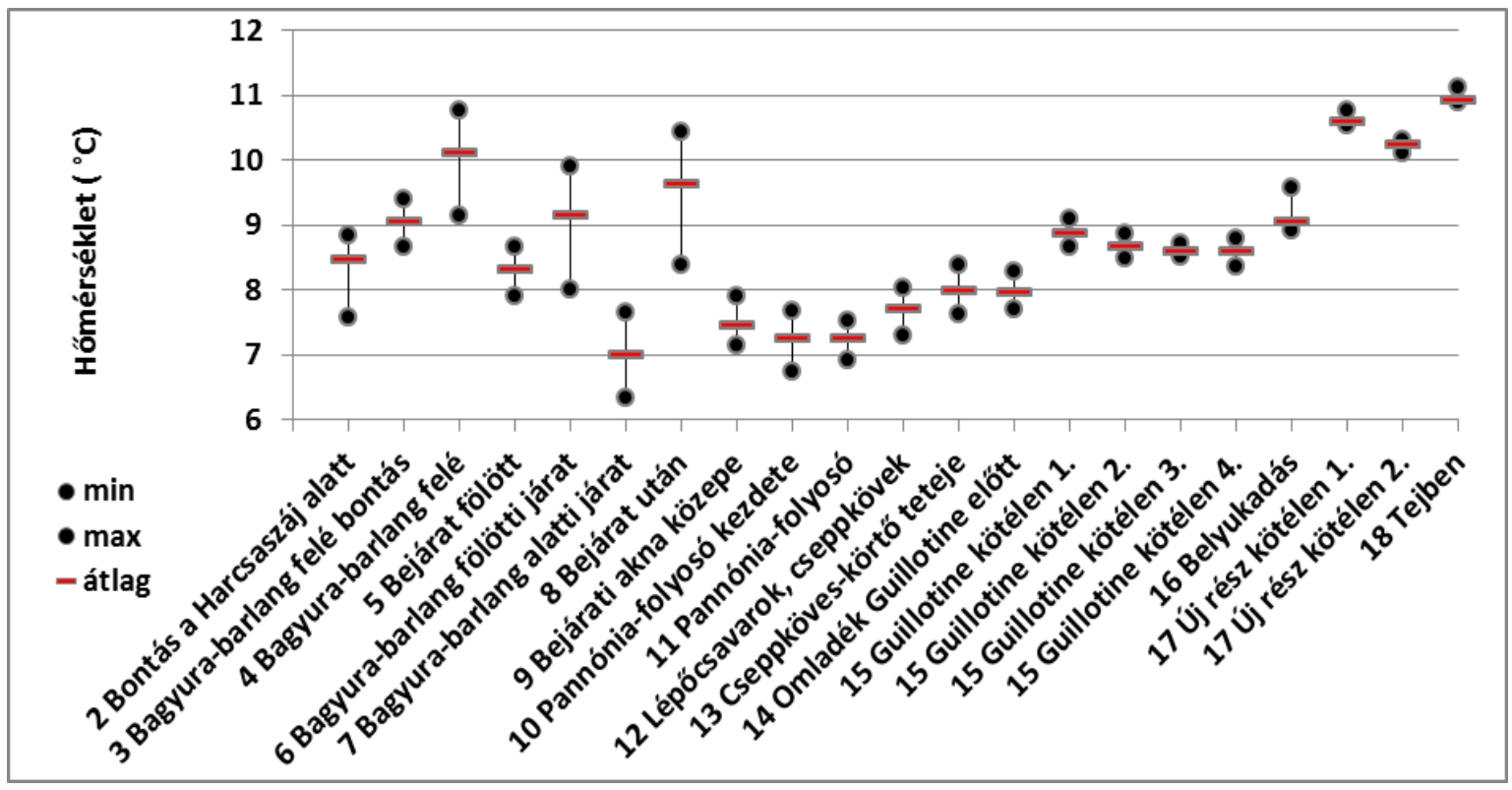

35. ábra A Harcsaszájú-barlang vizsgált pontjainak alapstatisztikai értékei 2013.04.28-2013.06.10 között

\section{Trió-barlang vizsgálati pontjainak tengerszint feletti magassága és hőmérséklete}

A Trió-barlangban 2012.04.20-2012.06.17 között végeztem egy két hónapos vizsgálatot, melynél a tavaszi légkörzést szerettem volna kimutatni. Ebben a vizsgálati időszakban $\mathrm{n}=7814 / 10$ perc adat állt a rendelkezésemre.

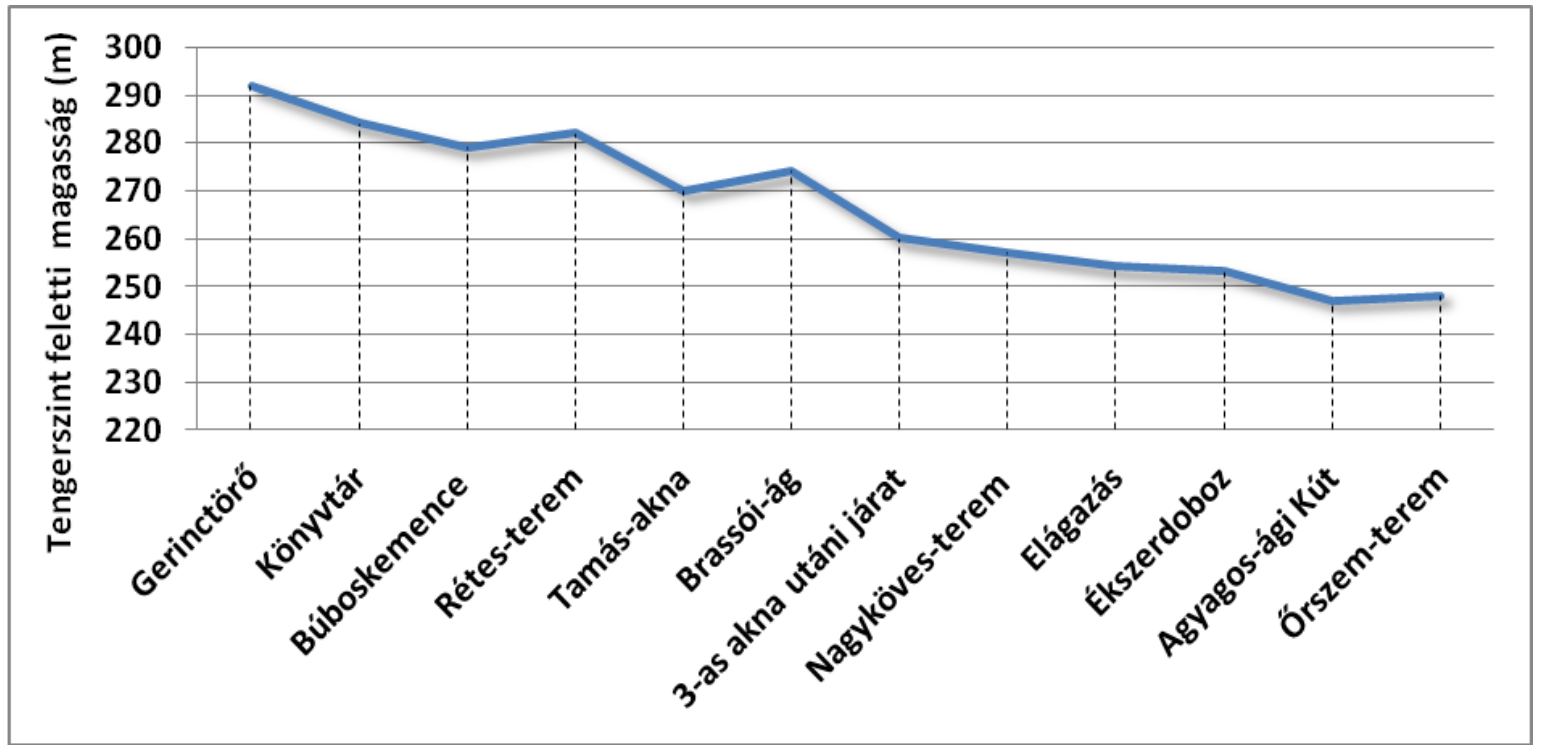

36. ábra A Trió-barlang vizsgált pontjainak tengerszint feletti magassága 
A barlang geometriája alapján völgytalpi zsákszerü barlangról beszélünk, a vertikális kiterjedése tszf. 292-248 m (36. ábra). A vizsgálati időszakban a barlang bejáratához közel a Szuadó-völgyben egy fán elhelyeztünk egy szenzort a felszíni adatok rögzítésére. Ennek hőmérséklete $3-28{ }^{\circ} \mathrm{C}$ között változott, átlagosan $14{ }^{\circ} \mathrm{C}$-ot mértem.

A Gerinctörő és a Könyvtár a bejárat és az 1-es akna elötti kuszodában helyezkednek, el. Itt a felszíni tavaszi lehülések még erőteljesen befolyásolják a lokális klímát, így itt $6,6-7^{\circ} \mathrm{C}$ között alakul a hömérséklet (37. ábra). Ez a hőmérséklet-változás a bejárati szakaszon azért is fontos, mert a barlang bejáratát a völgytalptól egy $3 \mathrm{~m}$-es akna választja el.

Az 1-es akna talppontjával megegyező magasságban helyezkedik el a Búbos kemence, majd innen a Rétes-terem 2 m-rel magasabban található, itt az átlagos hőmérséklet $8{ }^{\circ} \mathrm{C}$. A Tamás-akna és a Brassói-ág 12 m-rel mélyebben helyezkedik el, ezen a szakaszon kevesebb adat állt a rendelkezésemre, de itt már melegebb légtömeg volt 7,88,1 ${ }^{\circ} \mathrm{C}$ (37. ábra). A 3-as akna és az Elágazás között (ide tartozik a Nagyköves-terem is) már $1{ }^{\circ} \mathrm{C}$-al volt melegebb, pedig vertikálisan $10 \mathrm{~m}$-rel alacsonyabb járat szinten találhatók ezek a pontok, itt 9-9,2 ${ }^{\circ} \mathrm{C}$ az átlagos hőmérséklet. A Agyagos-ág végponti termében az Ékszerdobozban (37. ábra) $9,4{ }^{\circ} \mathrm{C}$, az ezen túli Kútban $10{ }^{\circ} \mathrm{C}$ volt a 2012 tavaszi légkörzésnél. A Vizes-ági végponti teremben az Örszem-teremben $9,7{ }^{\circ} \mathrm{C}$ volt.

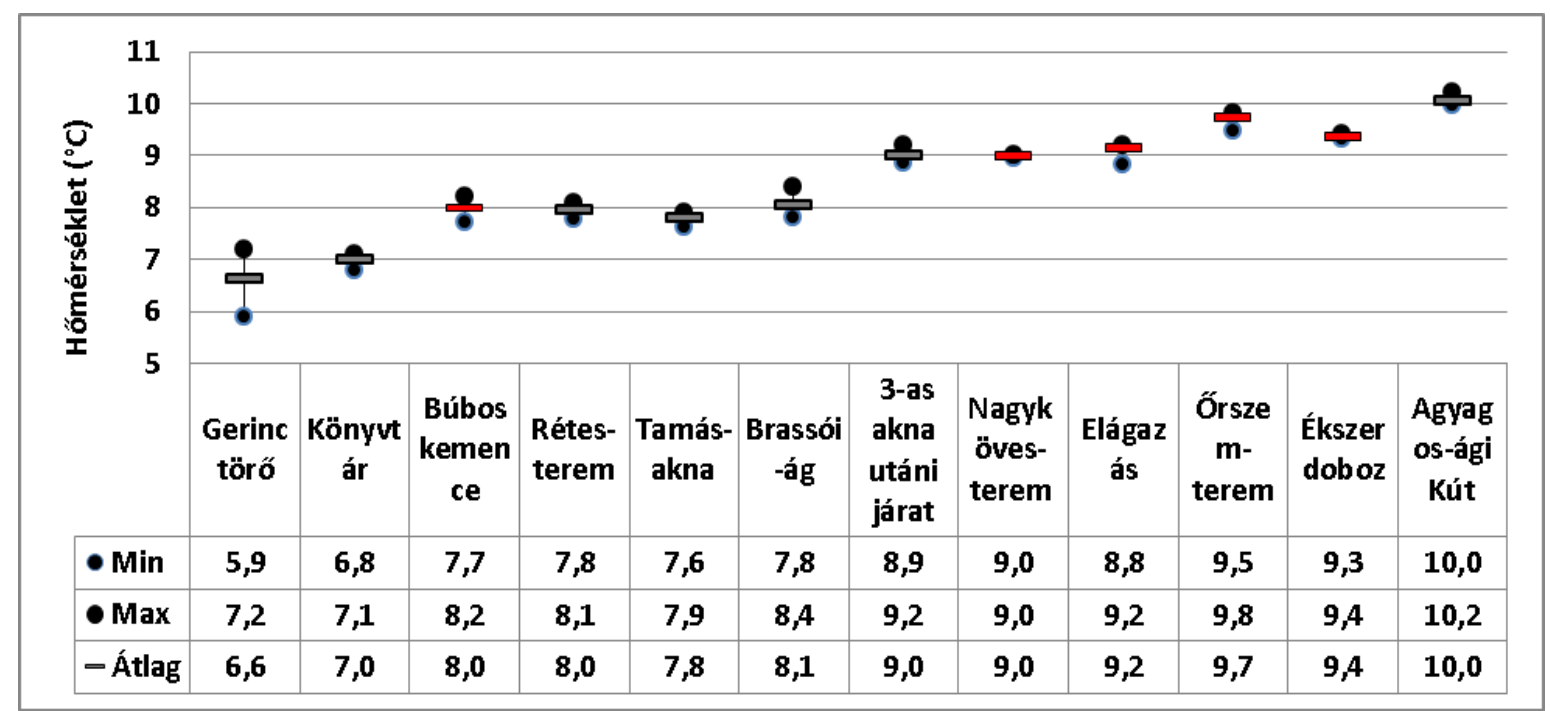

37. ábra A Trió-barlang vizsgált pontjainak alapstatisztikai értékei 2012.04.20-2012.06.17 között 


\section{Hideglyuk-Gábor Áron vizsgálati pontjainak tengerszint feletti magassága és hőmérséklete}

A Hideg-lyuk barlangban 2012.06.11.-06.25. között részletesebb vizsgálatot is végeztünk a vizsgált területen, és ezek közül a Gábor Áron-akna és Rézágyú-terem adatait szeretném bemutatni. Ennél a vizsgálatnál 10 perces adatsort használtam ahol $n=1739 \mathrm{db}$ időpont adata állt rendelkezésemre.

A mérés ideje alatt a felszínen az átlagos hőmérséklet $24{ }^{\circ} \mathrm{C}$, míg a maximum $36{ }^{\circ} \mathrm{C}$, a minimum $12,9^{\circ} \mathrm{C}$ volt. A $25 \mathrm{~m}$-es bejárati akna a Gábor Áron, mely tipikus példája a függőleges barlangok hőmérséklet eloszlásának (38. ábra39. ábra).

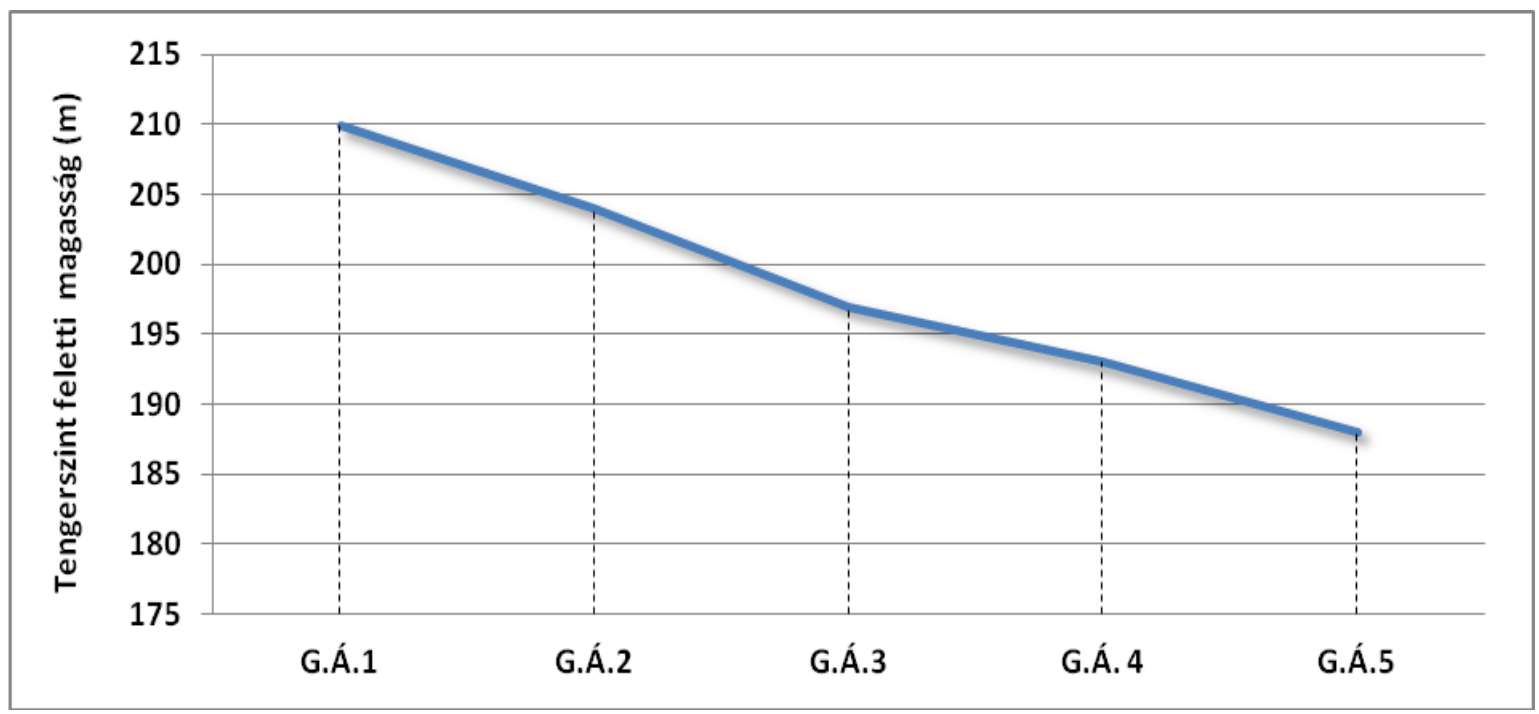

38. ábra A Hideg-lyuk Gábor Áron bejárata vizsgált pontjainak tengerszint feletti magassága

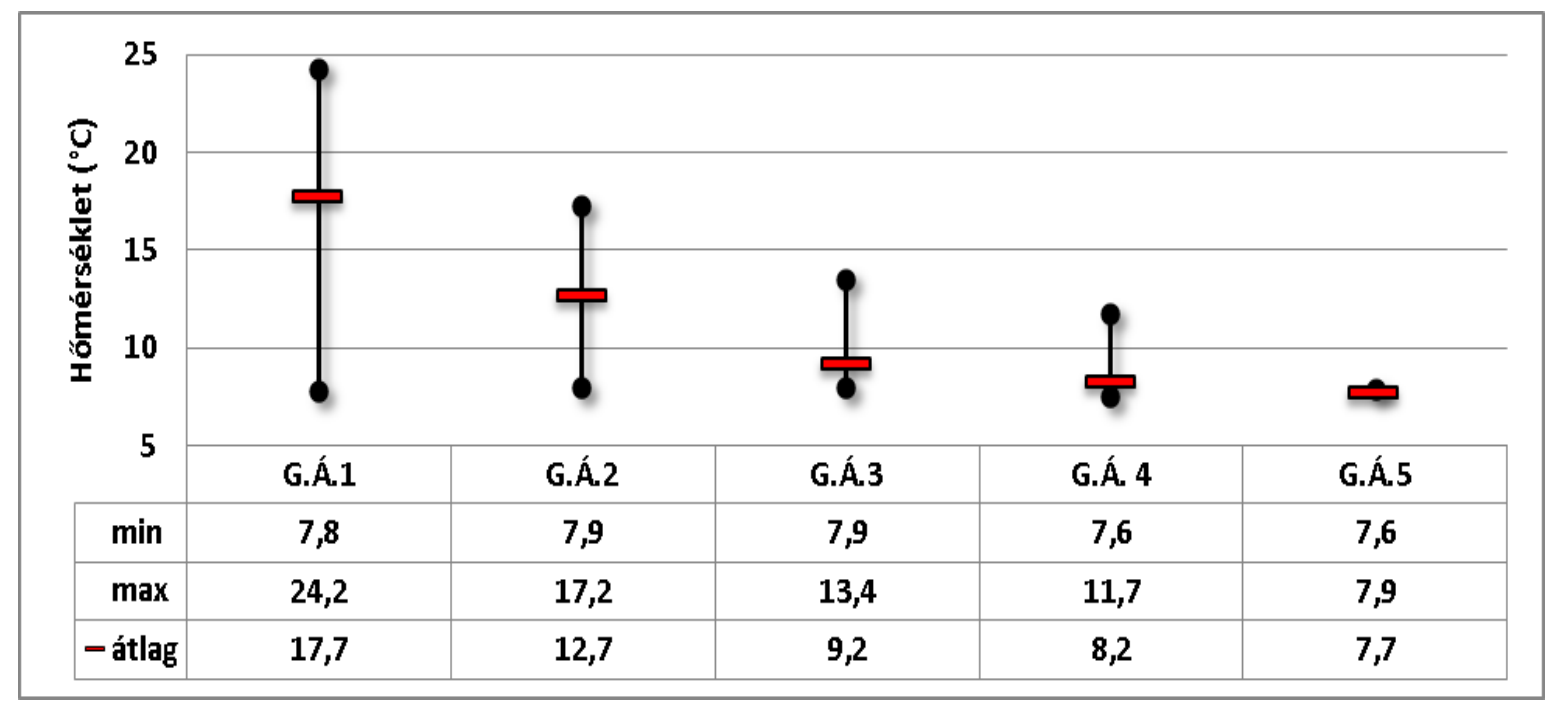

39. ábra A Hideg-lyuk Gábor Áron bejáratának vertikális hőmérséklet alapstatisztikai értékei 2012.06.11-2012.06.25 között 
Az aknában 5 métereként elhelyezett szenzorok esetében jól látszódik, hogyan gyengül folyamatosan a felszíni hatás, a felszíni $24{ }^{\circ} \mathrm{C}$-os átlagos hőmérséklet $5 \mathrm{~m}$-rel a felszín alatt $6,3{ }^{\circ} \mathrm{C}$-kal alacsonyabb, majd a következő pontnál $5{ }^{\circ} \mathrm{C}$-kal hűvösebb. Felülröl a harmadik pont esetében $3,5^{\circ} \mathrm{C}$ a különbség az előzőhöz képest, majd folyamatosan kiegyenlítődik a negyedik, és ötödik pontnál ahol $1{ }^{\circ} \mathrm{C}$ és $0,5^{\circ} \mathrm{C}$. Az akna átlag hőmérséklet szerinti rétegződése: $17,7-12,7-9,2-8,2-7,7^{\circ} \mathrm{C}$, tehát folyamatos hőmérséklet csökkenés figyelhető meg.

\section{Hideg-lyuk-Rézágyú-terem vizsgálati pontjainak tengerszint feletti magassága és hőmérséklete}

A Gábor Áron vizsgálatával egy időben a Rézágyú-teremben is kihelyezésre került 4 db müszer. A Rézágyú-terem egy barlangi járat példájaként jelenik meg, egy négyágú kereszteződés, ahol különböző keresztmetszeteken át áramlik a levegö. Az is érdekessége ennek a helynek, hogy a Gábor Árontól csak egy kisebb terem választja el, melynek talppontja a 14-es szenzorral van egy szinten. A Rézágyú-terembe bejutva láthatjuk meg ezt a keresztmetszetet (40. ábra).
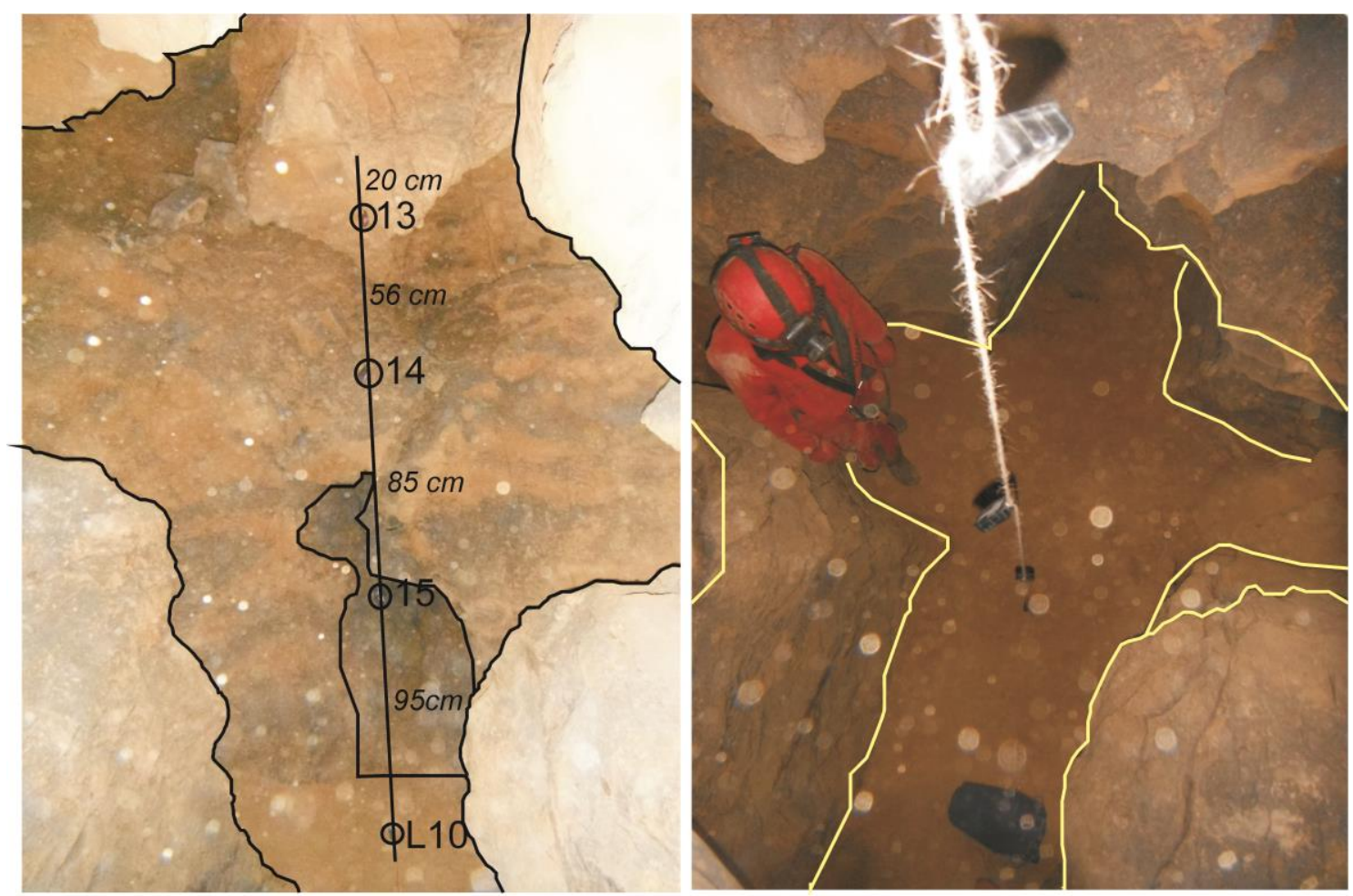

40. ábra A Hideg-lyukban a Rézágyú-teremben elhelyezett szenzorok keresztmetszeti és alaprajzi nézetben 


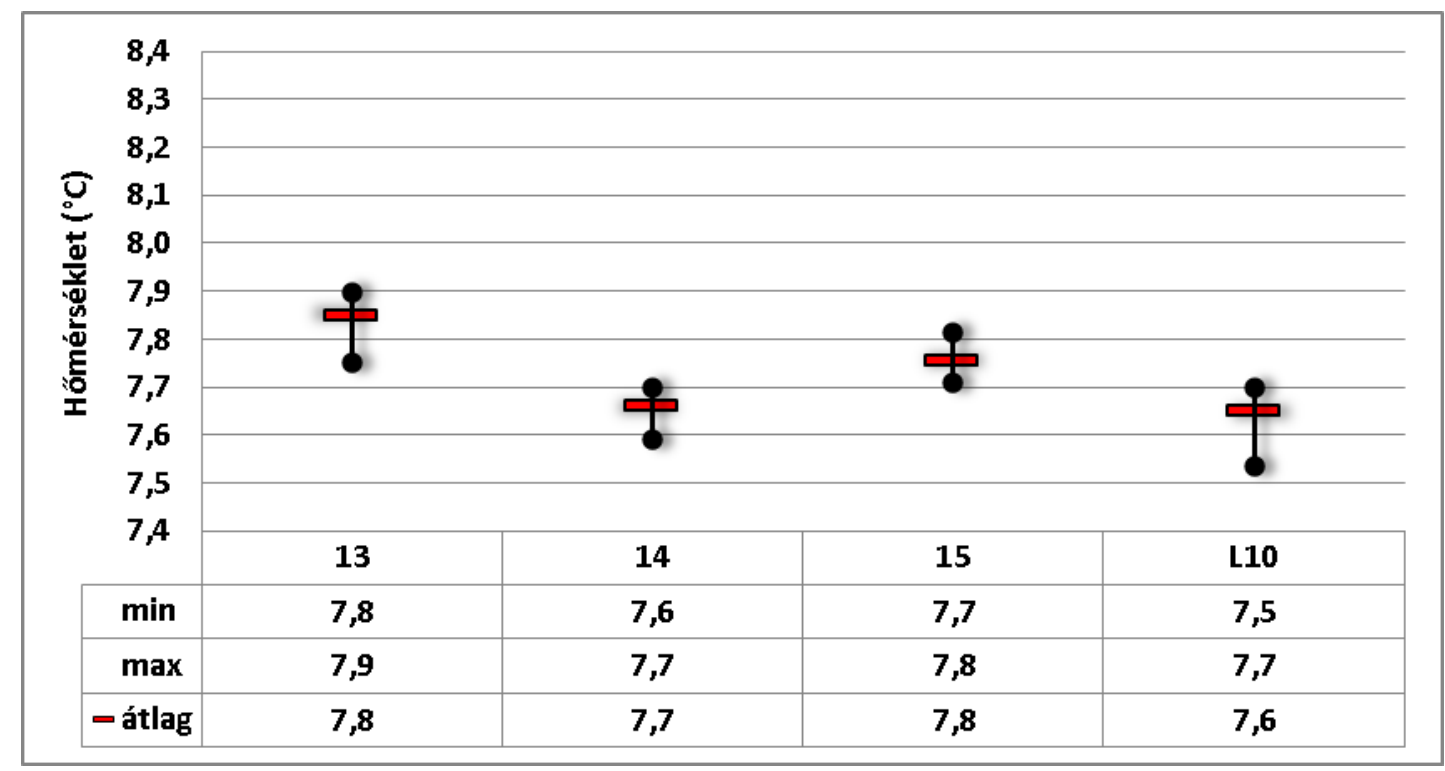

41. ábra A Hideg-lyukban a Rézágyú-terem vertikális megfigyeléseinek alapstatisztikai értékei 2013.06.11.-2013.06.25 között

A Gábor Áron legalacsonyabban elhelyezett müszere $7,6-7,9^{\circ} \mathrm{C}$ közötti rögzített hőmérsékletet, a Rézágyú-teremben is ezen értékek között változik a hőmérséklet (41. ábra). A kísérlet abból a szempontból volt érdekes, hogy a Rézágyú-teremben a nyári légkörzés esetén minimális felszíni hatások érvényesülnek, az akna nincs hatással erre a szakaszra. A kereszteződés hatására a terem középső szakaszán minimális örvénylés érezhető.

\section{2. Évszakos légáramlás változás vizsgálatok}

\subsubsection{A Hajnóczy-barlang hőmérsékletének éves menete}

A felszínen 2 méterrel barlang bejárata fölött elhelyezett szenzor mérte a külső levegő hőmérsékletét. A kapott adatsort a legközelebbi, szentléleki meteorológiai állomás adataival egészítettem ki (42. ábra). A két adatsor hőmérsékleti diagramja jól illeszkedik egymáshoz (a korrelációs együtthatójuk 0,95), egyedül a napi minimum és maximum értékek térnek el egymástól $1-2{ }^{\circ} \mathrm{C}-\mathrm{kal}$, aminek oka a müszerek helyének tengerszint feletti magasság különbsége. 
A felszíni adatok alapján, aszerint különböztettem meg a 4 évszakot, hogy a barlang Bejáratának hömérsékletéhez $\left(8^{\circ} \mathrm{C}\right)$ képest a felszínen mért érték hogyan változik $(42$. ábra):

- Tavasz: Tátl $>8{ }^{\circ} \mathrm{C}$ és $\mathrm{T}_{\min }<=8{ }^{\circ} \mathrm{C}$, emelkedő hőmérsékleti trend

A tavaszi időszak 2012. március 11. és 2012. május 22. között figyelhető meg, amikor a felszíni hőmérséklet $5-15^{\circ} \mathrm{C}$ között változik. A barlangon belül fokozatosan melegszik a hőmérséklet, de a lehülések következtében, a hidegebb levegő hatására jön létre nagyobb változás (18.-19 melléklet).

- Nyár: Tátl $>8^{\circ} \mathrm{C}$ és $\mathrm{T}_{\min }>8^{\circ} \mathrm{C}$

A nyári szakaszban egy fokozatosan melegedő tendencia figyelhető meg 2012. szeptember 19.-ig, ahol 12-30 C között változik a felszíni hőmérséklet.

A barlang bejáratánál megfigyelhető, hogy a nyári légkörzés idején a felszíni melegebb levegő nem módosítja ezt a szakaszt (42. ábra 2). A bejáratnál nyáron a szabadba tartó erőteljes légáramot figyelt meg Miklós Gábor is 1977 nyári mérései során a napi átlagos légáramlás-sebessége $27 \mathrm{~cm} / \mathrm{s}$ (Miklós, 1978). A grafikonon (42. ábra) is jól látható, hogy a bejáratnál a nyári időszakban egy simított görbe figyelhető meg, ahol a levegő $8^{\circ} \mathrm{C}$ hőmérsékletü, minimális $0,5^{\circ} \mathrm{C}$ alatti változással (21. melléklet).

- Ösz: Tátl $>8^{\circ} \mathrm{C}$ és $\mathrm{T}_{\min }<=8^{\circ} \mathrm{C}$, csökkenő hömérsékleti trend

Az öszi szakaszban fokozatos lehülés figyelhetö meg 2012. október 19-ig, ahol a minimum értékek $5{ }^{\circ} \mathrm{C}$ körül találhatók. Amint a felszíni hőmérséklet $10{ }^{\circ} \mathrm{C}$ alá esik a légáramlás iránya megfordul, és a felszíni hőmérséklet befolyásolja a Bejárati szakaszt. A őszi időszakban válik ez a jelenség láthatóvá, így a Bejáratnál 6-8 ${ }^{\circ} \mathrm{C}$ között változik a hőmérséklet (21. melléklet).

- Tél: $\mathrm{T}_{\text {átl }}<8^{\circ} \mathrm{C}$ és $\mathrm{T}_{\min }<8^{\circ} \mathrm{C}$

A téli szakasznál (2012.10.22.-2013.04.12.) már fagypont alatti hőmérsékletet is regisztráltunk, ahol hőmérsékleti tartomány $-6-5^{\circ} \mathrm{C}$ között található. A negyedik szakasz utolsó napjaiban a napi maximumok már $5^{\circ} \mathrm{C}$ fölé emelkednek (42. ábra). A téli időszakban a hideg sürü levegő lefolyik a bejárati szakaszon, így erőteljes hőingásokat gerjeszt $-1,3-6{ }^{\circ} \mathrm{C}$ között. 


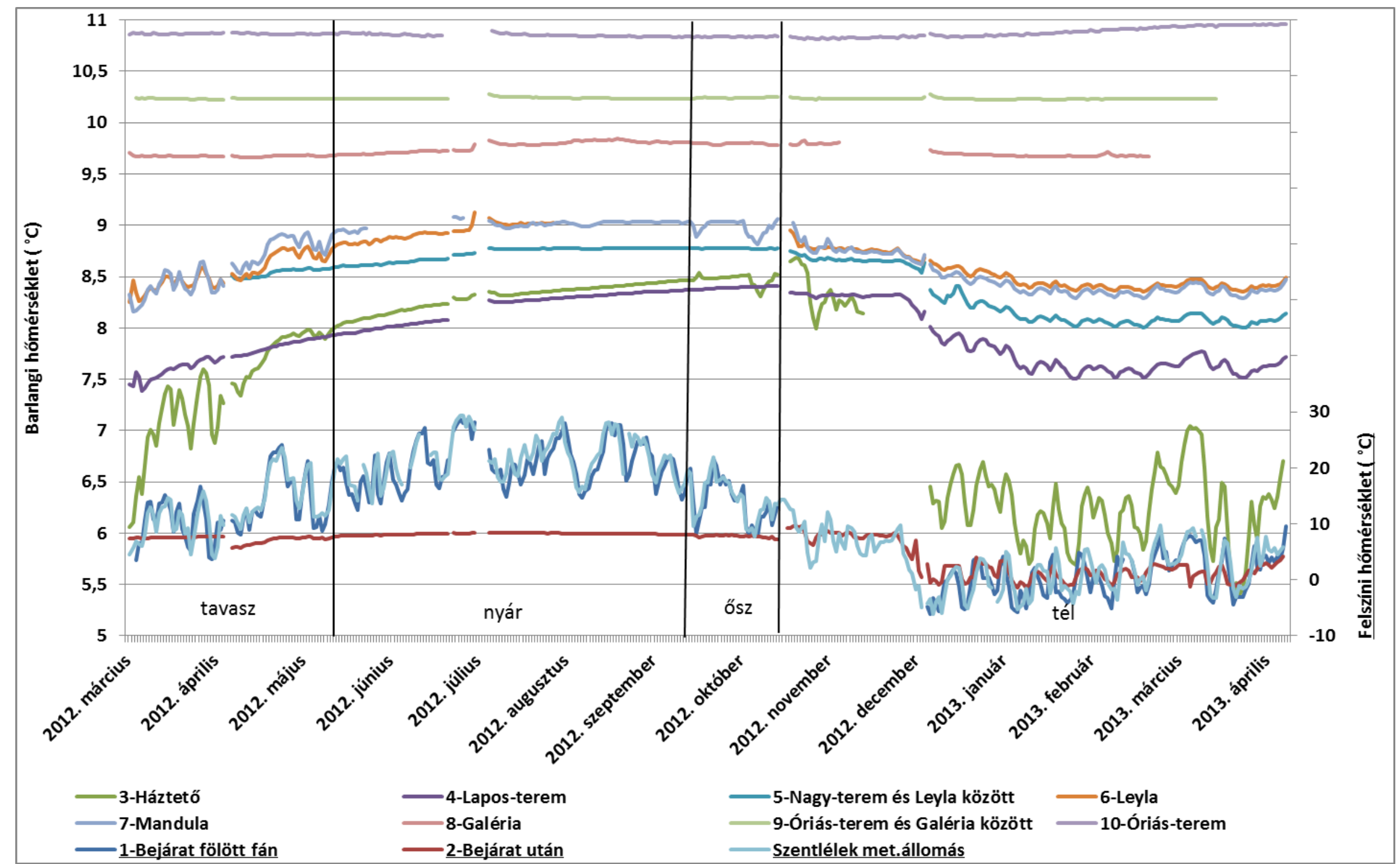

42. ábra A Hajnóczy-barlang hőmérsékletének éves menete (2012.március-2013.április) Másodlagos tengelyen: 1-Bejárat fölött fán, 2- Bejárat után, és a Szentléleki meteorológiai állomás adatai 
10. táblázat A Hajnóczy-barlang évszakonkénti hőingása, és az évszakokban jellemző napi hőingás értékei

\begin{tabular}{|c|c|c|c|c|c|c|c|c|}
\hline \multirow{2}{*}{ Mérési pont } & \multicolumn{2}{|c|}{ Tavasz } & \multicolumn{2}{|c|}{ Nyár } & \multicolumn{2}{|c|}{ Ösz } & \multicolumn{2}{|c|}{ Tél } \\
\hline & $\Delta \mathrm{T}$ & $\Delta \mathrm{T}_{\text {nap }}$ & $\Delta \mathrm{T}$ & $\Delta \mathrm{T}_{\text {nap }}$ & $\Delta \mathrm{T}$ & $\Delta \mathrm{T}_{\text {nap }}$ & $\Delta \mathrm{T}$ & $\Delta \mathrm{T}_{\text {nap }}$ \\
\hline 1-Bejárat fölött & 19,1 & 14,9 & 24,7 & 12 & 13,2 & 7,7 & 19,2 & 10 \\
\hline 2- Bejárat után & 1,8 & 1,45 & 0,5 & 0 & 0,3 & 0,3 & 11 & 2,68 \\
\hline 3-Háztető & 1,9 & 0,37 & 0,5 & 0 & 0,2 & 0,2 & 3,2 & 1,5 \\
\hline 4-Lapos-terem & 0,5 & 0,1 & 0,4 & 0 & 0,1 & 0 & 0,8 & 0,17 \\
\hline 5-Nagy-t. és Leyla & 0,4 & 0,2 & 0,1 & 0 & 0 & 0 & 0,7 & 0,1 \\
\hline 6-Leyla & 0,5 & 0,3 & 0,4 & 0 & - & - & 0,6 & 0,1 \\
\hline 7-Mandula & 0,8 & 0,3 & 0,1 & 0 & 0,2 & 0,2 & 0,8 & 0,1 \\
\hline 8- Galéria & 0 & 0 & 0,2 & 0 & 0 & 0 & 0,1 & 0 \\
\hline 9-Galéria és Óriás-t. & 0 & 0 & 0 & 0 & 0 & 0 & 0 & 0 \\
\hline 10-Óriás-terem & 0 & 0 & 0 & 0 & 0 & 0 & 0,1 & 0 \\
\hline
\end{tabular}

Klaszteranalízis vizsgálata során a különböző évszakokban a 3-Háztető adatsora a 4Lapos-terem, 5-Nagy-t. és Leyla, 6-Leyla, 7-Mandula adataival tartozik egy klaszterbe. Ezt a kapcsolatot már a megelőző vizsgálatok is bizonyítják a szoros korreláció miatt (Muladi, et al., 2013d) Itt a hőmérséklet 5,4-8,6 ${ }^{\circ} \mathrm{C}$ között mozog (42. ábra 3), a vizsgált időszakban télen volt a legnagyobb hőingás $3,5^{\circ} \mathrm{C}$, tavasszal $1,9^{\circ} \mathrm{C}$ (10. táblázat).

A Lapos-teremben elhelyezett szenzor vertikálisan a legmélyebben fekvő pont a bejárattól 47 m vertikális távolságra helyezkedik el. Itt már a felszíni hőmérsékleti trendek jelennek meg, bár a napi hőingás a nyári időszakban nem látható, a téli időszakban már megjelenik ezen a ponton is $\left(7,4-8,4{ }^{\circ} \mathrm{C}\right)(42$ ábra 4$)$.

A következő vizsgálati pont a Nagy-terem és Leyla között helyezkedik el. A Nagyterem 48 m hosszú és 14 méter széles, magassága 5-8 m. Innen továbbhaladva Leyla és a Mandula egyre szűkülő keresztmetszetü járatai következnek, mely járat a Galériával biztosítja az összeköttetést (13.ábra). A három vizsgálati pont közel azonos hőmérséklet tartományba esik, de a vertikális rétegzettség ezen a 2-3 m szintkülönbségen is látható (42. ábra 5,6,7). A keresztmetszetében egyre szükülő járatban a hőmérsékleti trendek szinte ugyanazok, elkülöníthető a téli-nyári légkörzés (42. ábra 5,6,7). A nyári időszakban a barlangból kifelé áramló levegő a domináns, ekkor a hőingás ezen a szakaszon 0,1$0,4{ }^{\circ} \mathrm{C}$, míg télen $0,6-0,8^{\circ} \mathrm{C}$ (10. táblázat). 
Cseppkövekben rendkívül gazdag Galéria, amely $70 \mathrm{~m}$ hosszú, 1-8 m széles, s magassága 4-13 m. A Galéria cseppkő gazdagságát az okozza, hogy a mennyezetét függőlegesen álló mészkőlapok alkotják, amelyek mentén állandóan csepegett a mésztartalmú víz. A Galéria keleti végéböl, beomlott több tonnás sziklatömbök között lehet feljutni a 63 m hosszú, 14 m magas és 16 m széles Óriás-terembe (13.ábra). Az utolsó három vizsgálati pont esetében a nagyméretü termek és omlások miatt nem észlelhetők erőteljes évszakos változások (10. táblázat). A térbeli rétegzettségük is jól látható az adatokon (42. ábra 8,9,10).

\subsubsection{A Hideg-lyuk hőmérsékletének éves menete}

A Hideg-lyuk-barlangban is végeztem hosszú távú vizsgálatokat, így a barlang éves menetének vizsgálatára is lehetőség nyílt. A vizsgált periódus 2012. május-2014. április volt (43. ábra). Mivel a Hideg-lyuk Alsó bejáratának átlagos hőmérséklete a barlangból kifelé húzó légáramlat esetén $8,89^{\circ} \mathrm{C}$, ezért a felszíni adatok alapján a $9{ }^{\circ} \mathrm{C}$-tól való eltérést vettem alapul. Ebben az időszakban $7 \mathrm{db}$ periódust tudtam lehatárolni a felszíni hőmérséklet-változás alapján:

- Nyár: Tátl $>9{ }^{\circ} \mathrm{C}$ és $\mathrm{T}_{\min }>9^{\circ} \mathrm{C}$

2012.május 17. - október 6. nyári periódus idején emelkedő trend jellemezi a barlangi hőmérsékletet, ugyanis a felszíni hömérséklet $10-40{ }^{\circ} \mathrm{C}$ között mozog. Ebben az időszakban a Bejáratra erős kifelé áramló huzat a jellemző $\left(9,1^{\circ} \mathrm{C}\right)$. A Bányatámoknál 7,1-ről $8,4^{\circ} \mathrm{C}$-ra növekszik a hőmérséklet egy simított görbe mentén, ugyanez jellemző a Referencia-bivaknál $\left(7,4-8,6^{\circ} \mathrm{C}\right)$ és a Rézágyúteremnél is $\left(8-9^{\circ} \mathrm{C}\right)$. A Medvecsapda $\left(7,6-9,1^{\circ} \mathrm{C}\right)$ és a Guillotine $\left(8-9,6^{\circ} \mathrm{C}\right)$ esetében nem csak a trend emelkedik, hanem a napi hőingás is erőteljesen módosítja a vizsgálati pontok hőmérsékletét (11. táblázat). A Lépőcsavarok esetében is egy emelkedő simított trend látható $0,5^{\circ} \mathrm{C}$-ot emelkedik a hőmérséklet. A Pecsétnyomó, és a Karácsony-terem esetében nem érzékelhető lényeges változás (22. melléklet).

- Oosz: $\mathrm{T}_{\text {átl }}>9{ }^{\circ} \mathrm{C}$ és $\mathrm{T}_{\min }<=9{ }^{\circ} \mathrm{C}$, csökkenő hőmérsékleti trend 2012. október 6. - november 20. őszi periódus figyelhető meg. A felszíni hőmérséklet $-1-25^{\circ} \mathrm{C}$ között változik, a Bejáratnál és a Bányatámoknál a nagyobb felszíni lehủlések megmutatkoznak. A többi pont esetében az előbbiekben leírt 
változások jellemzőek, de már elérték a maximumukat az egyes járatok hőmérsékletei, és egy adott érték körül ingadoznak (23. melléklet).

- Tél: $\mathrm{T}_{\text {átl }}<9{ }^{\circ} \mathrm{C}$ és $\mathrm{T}_{\min }<9{ }^{\circ} \mathrm{C}$

2012. november 20. - 2013.május 4.-ig a téli periódus figyelhető meg. Ebben az időszakban $-8-15{ }^{\circ} \mathrm{C}$ között változik a felszíni hőmérséklet. A barlangi változásokat ezen időszakon belül két részre osztom, mivel december 26-tól február 22- ig a barlangban $0,5^{\circ} \mathrm{C}$-os csökkenés mutatkozik, a Bányatámoknál $1,2^{\circ} \mathrm{C}$, a Bejáratnál pedig $5{ }^{\circ} \mathrm{C}$ hülés jellemző (43. ábra) (24. melléklet).

Február végén intenzív hőmérséklet csökkenés kezdődik $\mathrm{A}$ Bejárat $\left(-3-8^{\circ} \mathrm{C}\right)$ és a Bányatámok $\left(4-8{ }^{\circ} \mathrm{C}\right)$ esetében is erőteljesen hat a felszíni hideg levegö. A többi pont esetében (Rézágyú-terem, Referencia-bivak, Medvecsapda, Guillotine) is eltűnnek a napi hőingás okozta változások, de a felszíni lehűlést követik $1,5^{\circ} \mathrm{C}$-ot csökken a hőmérséklet. Ez lehülés annak volt köszönhető, hogy Buda fölött egy intenzív hidegfront okozott február 20-án hózáport ( Pátkai, et al., 2013.). A 2013. március 14-15-én kialakult hóvihar (Horváth, 2013.) nem jelentett hirtelen hőmérséklet csökkenést a barlangban, de folyamatosan hülő trend jellemzi ezt az időszakot is (24.-25 melléklet).

- Tavasz: $\mathrm{T}_{\text {átl }}>9{ }^{\circ} \mathrm{C}$ és $\mathrm{T}_{\min }<=9{ }^{\circ} \mathrm{C}$, emelkedő hőmérsékleti trend

A tavaszi időszak csak egy rövid ideig volt megfigyelhető 2013. május 4. június 13.

Ebben az időszakban jellemző, hogy a felszíni maximum értékek hatására többször is megfordulhat a légáramlás iránya. A felszíni hőmérséklet ebben az időszakban $10-20{ }^{\circ} \mathrm{C}$ körül alakul (43. ábra), ekkor a barlangon belüli hőingás $0,1-0,8^{\circ} \mathrm{C}$ között alakul (11. táblázat).

- Nyár: Tátl $>9{ }^{\circ} \mathrm{C}$ és $\mathrm{T}_{\min }>9^{\circ} \mathrm{C}$

A nyári légkörzés ideje 2013. június 13. és október 12. között jellemző, ennek kezdete igencsak eltolódott a június elejei hüvös időjárás miatt (Vincze, et al., 2013.). A müszerek cseréje pont az nap történt, amikor a barlangi hömérséklet ténylegesen átváltott nyári légkörzésre, és a Rézágyú-terem, Referencia-bivak, Medvecsapda, Guillotine pontok esetében megemelkedett $1,5{ }^{\circ} \mathrm{C}-\mathrm{kal}$. A Bányatámok is $5,5-7,5^{\circ} \mathrm{C}$ (43. ábra). A Bejáratnál elhelyezett hőmérsékletmérő ebben az időszakban nem müködött.

- Ösz: Tátl $>9{ }^{\circ} \mathrm{C}$ és $\mathrm{T}_{\min }<=9{ }^{\circ} \mathrm{C}$, csökkenő hőmérsékleti trend 
2013. október 12. - november 11. között őszi hőmérséklet-változás jellemző, ekkor már volt egy $0{ }^{\circ} \mathrm{C}$-os felszíni lehülés, ami a Bányatámoknál is $0,8^{\circ} \mathrm{C}$-os csökkenést jelentett (43. ábra).

- Tél: $\mathrm{T}_{\text {átl }}<9^{\circ} \mathrm{C}$ és $\mathrm{T}_{\min }<9^{\circ} \mathrm{C}$

2013. november 11-től télire vált a barlang klímája egészen a vizsgált időszak végéig (2014.április 24.). Ebben az időszakban az enyhébb télnek köszönhetően tompítottabban jelentkeznek a hideg sürübb levegő módosító hatásai. A felszínen csak február közepén volt $-8{ }^{\circ} \mathrm{C}$, mely hatására a Bányatámoknál $2{ }^{\circ} \mathrm{C}$-os hőmérséklet csökkenés volt, a többi járat esetében $1{ }^{\circ} \mathrm{C}$-ot csökkent a hőmérséklet (43. ábra). Ez a jelenség azzal magyarázható, hogy a február 12-én és 14-én viharciklon jelent meg az ország fölött (Horváth, Nagy , 2014).

11. táblázat A Hideg-lyuk évszakonkénti hőingása, és az évszakokban jellemző napi hőingás értékei

\begin{tabular}{lcccccccc}
\hline \multirow{2}{*}{ Mérési pont } & \multicolumn{2}{c}{ Nyár } & \multicolumn{2}{c}{ Ösz } & \multicolumn{2}{c}{ Tél } & \multicolumn{2}{c}{ Tavasz } \\
& ${ }_{\Delta} \mathrm{T}$ & ${ }_{\Delta} \mathrm{T}_{\text {nap }}$ & ${ }_{\Delta} \mathrm{T}$ & ${ }_{\Delta} \mathrm{T}_{\text {nap }}$ & ${ }_{\Delta \mathrm{T}}$ & ${ }_{\Delta} \mathrm{T}_{\text {nap }}$ & ${ }_{\Delta} \mathrm{T}$ & ${ }_{\Delta} \mathrm{T}_{\text {nap }}$ \\
\hline Felszín & 30 & 19 & 25,9 & 16 & 27,9 & 10 & 25 & 16 \\
\hline 1-Bejárat & 1 & 0 & 3,7 & 1,5 & 11,7 & 2 & - & - \\
\hline 2-Bányatámok & 1,2 & 0,1 & 0,1 & 0,1 & 4,3 & 0.2 & 0,8 & 0,1 \\
\hline 3-Rézágyú-terem & 0,8 & 0,1 & 0,2 & 0,1 & 1,1 & 0 & 0,3 & 0,1 \\
\hline 4-Referencia-bivak & 1,3 & 0,05 & 0,1 & 0 & 1,7 & 0 & 0,2 & 0 \\
\hline 5-Pecsétnyomó & 0,4 & 0,05 & 0,2 & 0 & 0,3 & 0 & 0,2 & 0 \\
\hline 6-Karácsony-terem & 0,3 & 0 & 0,1 & 0 & 0,2 & 0 & 0,1 & 0 \\
\hline A-Medvecsapda & 1,5 & 0,5 & 0,4 & 0,3 & 2 & 0 & 0,5 & 0,3 \\
\hline B-Guillotine & 1,7 & 0,3 & 0,4 & 0,2 & 2,4 & 0 & 0,1 & 0,1 \\
\hline C-Lépőcsavarok & 0,5 & 0 & 0,1 & 0,1 & 0,3 & 0 & 0,3 & 0,05 \\
\hline
\end{tabular}




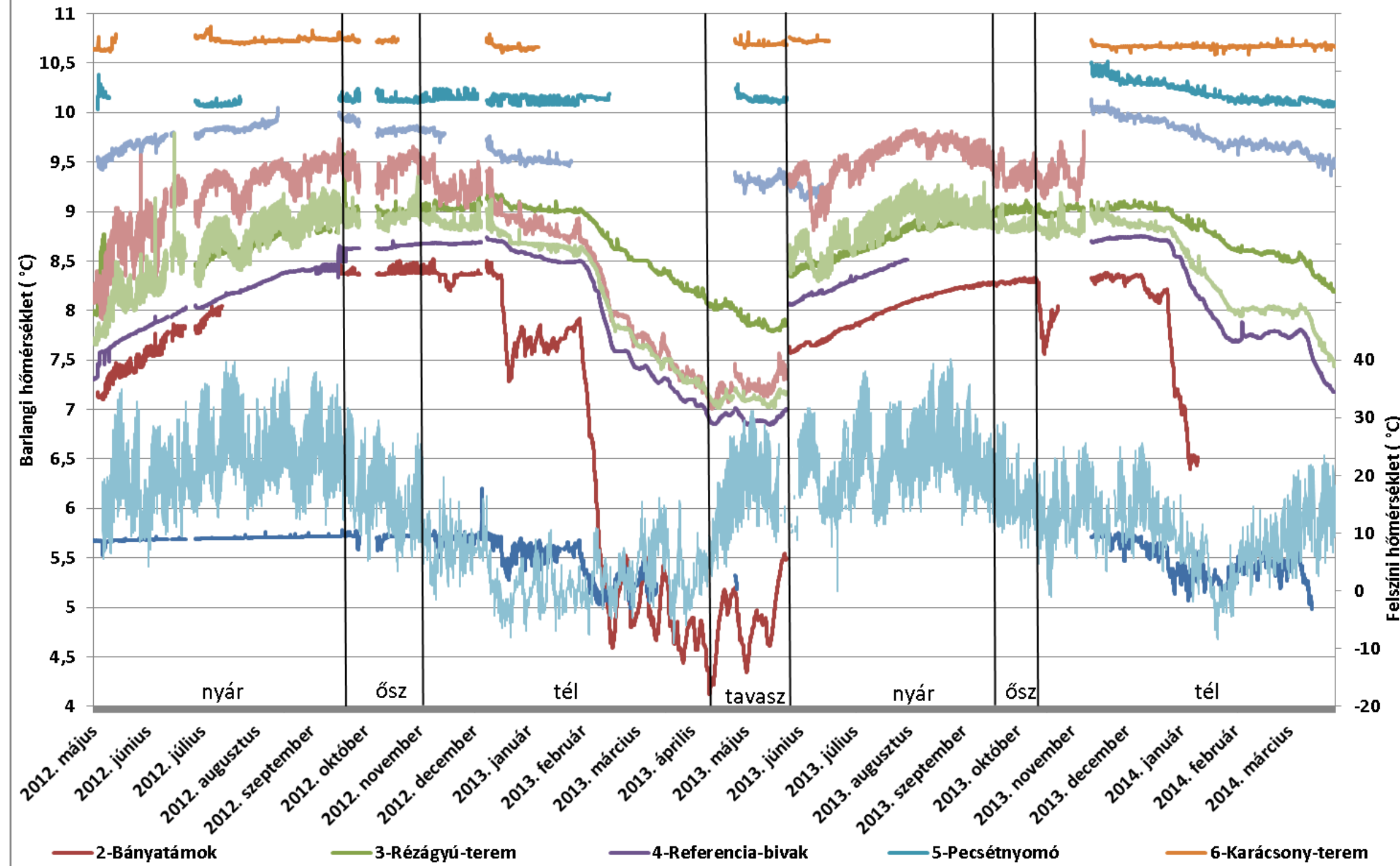


A Hideg-lyuk a bonyolult légkörzésü barlangok egyike, így további kutatási célból radon mérők kihelyezésére került sor a barlangban a léghőmérséklet mérőmüszerek mellé, a pontosabb légmozgás meghatározása céljából. Többszöri mérést végeztem a radon szint pontosabb megállapítása érdekében, az első mérés 2012.09.11.-10 21. között történt az nyár végi idején mind a 9 barlangi vizsgált helyszínen (44. ábra). A második mérés a téli légáramlás változása ideje alatt történt 2013.02.06.-04.27 (44. ábra).

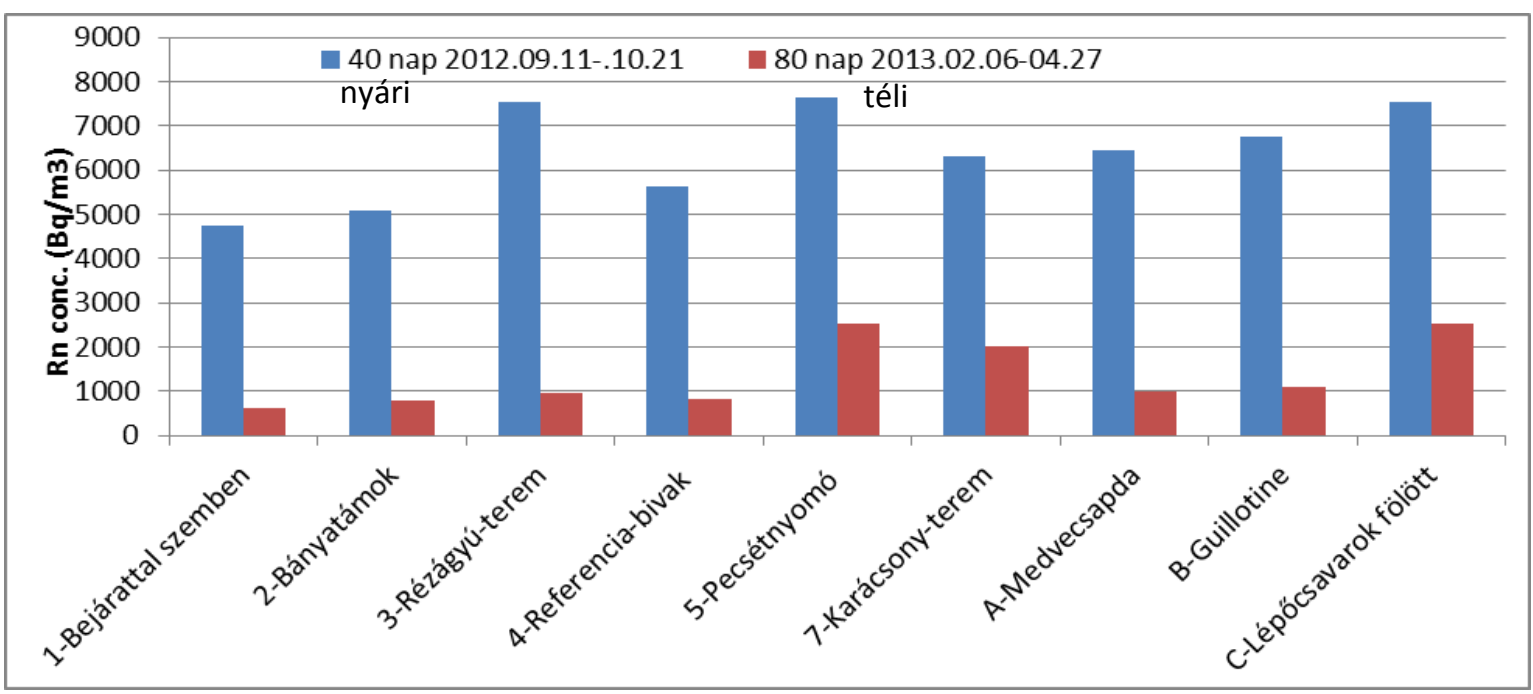

44. ábra Hideg-lyuk radon szintjének két mérési időszaka 2012.09.11.-10 21. valamint 2013.02.06.-04.27. az összes vizsgálati pontban

További vizsgálatokat folytattam a Bányatámok, Rézágyú-terem, Pecsétnyomó, Guillotine után, és a Karácsony-terem esetében 2013.04.27.-2013. 06.15. közötti tavaszi és a 2013.06.15-10 21. nyári időszakban (45. ábra).

Az első és a második időszak tipikus példája a szeptember-októberi időszak: a hőmérsékletadatok alapján még az késő nyári radon szint jellemző, a nyári radon szintről nem tudjuk, mennyi lehetett a maximuma, míg a február-áprilisi légkörzés idején a téli radon koncentráció látható, ahol a hőmérsékleti adatok alapján még téli befelé húzó légáramlás a jellemző. A hőmérséklet adatok alapján látható, hogy 2012.10.20-a körül fordult át őszi légkörzésre, a nyári légkörzés idején végig magas a radon koncentráció 4745-7648 Bq/m³ között mozog, míg a téli légkörzés ideje alatt legtöbb helyen több mint hatodára esik vissza ez az érték (623-1130 Bq/ $\mathrm{m}^{3}$ ). Három helyen viszont más folyamatok érvényesülnek a Pecsétnyomó, a Karácsony-terem, és a Lépőcsavarok fölött, ahol csak harmadával csökken a radon szint (2020-2542 Bq/m³). Az évi hőmérséklet-változásnál 
levont következményt tehát ez is igazolja, hogy ezen a szakaszon már barlangi levegő található, és itt már lassabban szellőznek át a járatok.

A Rézágyú-terem, mely a Gábor Áron aknabejárat aljánál található az első mérési szakaszban (44. ábra) meglepően magas radon szintet mutat $\left(7546 \mathrm{~Bq} / \mathrm{m}^{3}\right)$. Ilyen magas radon szint csak a Pecsétnyomóban található $\left(7648 \mathrm{~Bq} / \mathrm{m}^{3}\right)$, mely a barlangi szakaszhoz tartozik. Erre az lehet a magyarázat, hogy a Rézágyú-terem egy - az akna hatása miatt gyengébben szellőző - járat az őszi időszakban, így a radon koncentráció megemelkedhet.

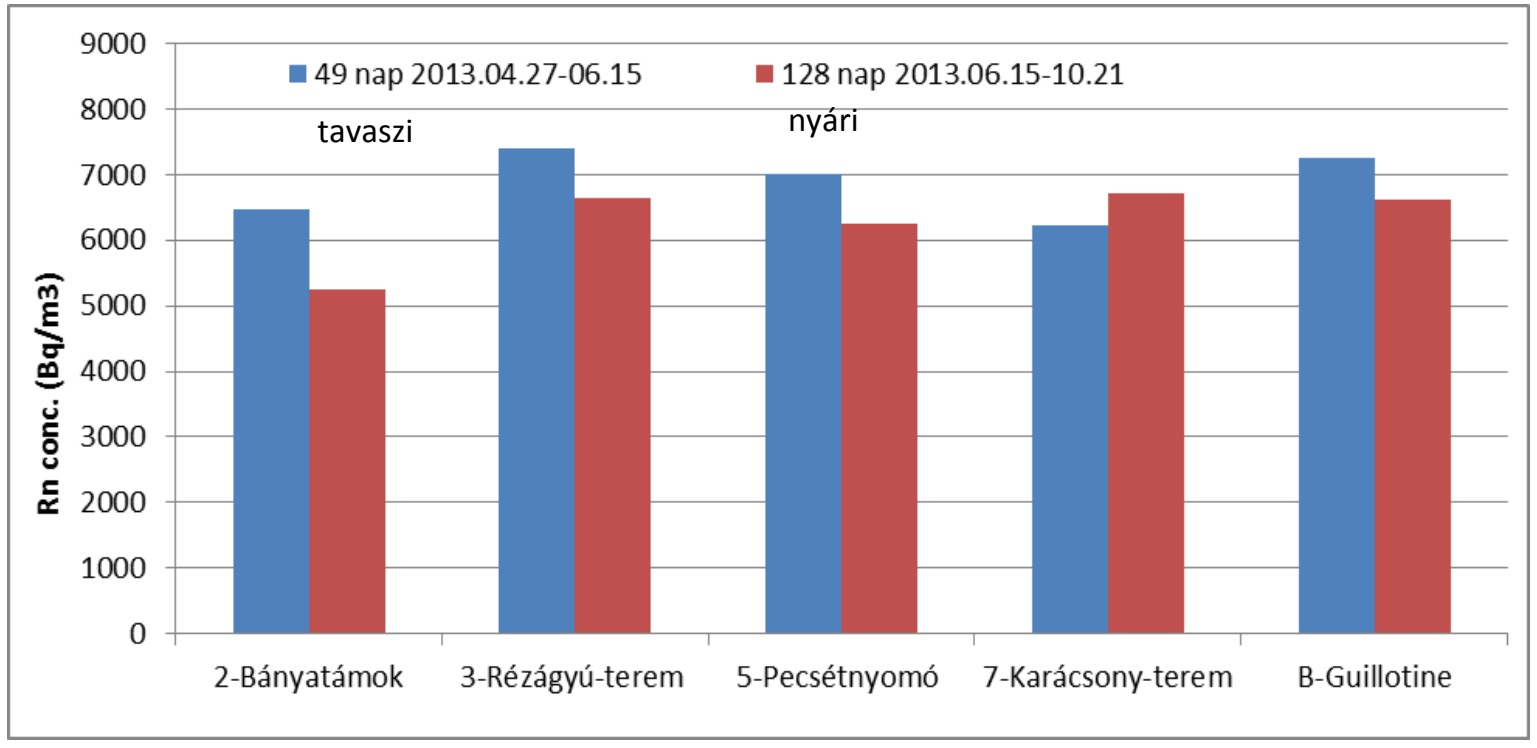

45. ábra Hideg-lyuk radon szintje 2013.04.27.-2013. 10 21. közötti időszakban 5 db vizsgálati pontban

A téli légkörzés idején még a téli hidegebb levegő okoz módosítást, mivel az akna alján megül a friss, nehezebb, hideg levegö, így gyorsabban cserélődik ki a Rézágyú-terem levegője (44. ábra).

A harmadik és negyedik radon vizsgálati időpontot tekintve már egy kiegyenlítettebb képet láthatunk, mivel a tavaszi-kora nyári időszakban 49 nap volt a mérési periódus, a nyári-őszi időszakban pedig a 128 nap, így a kumulált adatok alapján a tavaszi és nyári légkörzés változásai nem láthatók (45. ábra). 


\subsection{Aperiodikus hatások}

\subsubsection{Hajnóczy-barlang antropogén hatás mértéke}

A 2012-es Hajnóczy József Barlangkutató Sportegyesület által szervezett nyári tábor idején történt mérési időszak 2012.06.30.-07.09.-ig. Ez idő alatt összesen 61 fő tartózkodott a barlangban különböző terepbejárások alkalmával (46. ábra).

A barlangban elhelyezett szenzorokat a bejárattól való távolság és a különbözö magasságban elhelyezkedö barlangi termek alapján több csoportba sorolhatjuk. Ebben az időszakban $32 \mathrm{db}$ szenzorral mértük a hőmérsékletet. A vizsgált barlangszakaszon 5 különböző csoportot különítettünk el, valamint a bejáratnál a felszínen elhelyezett szenzort (47. ábra).

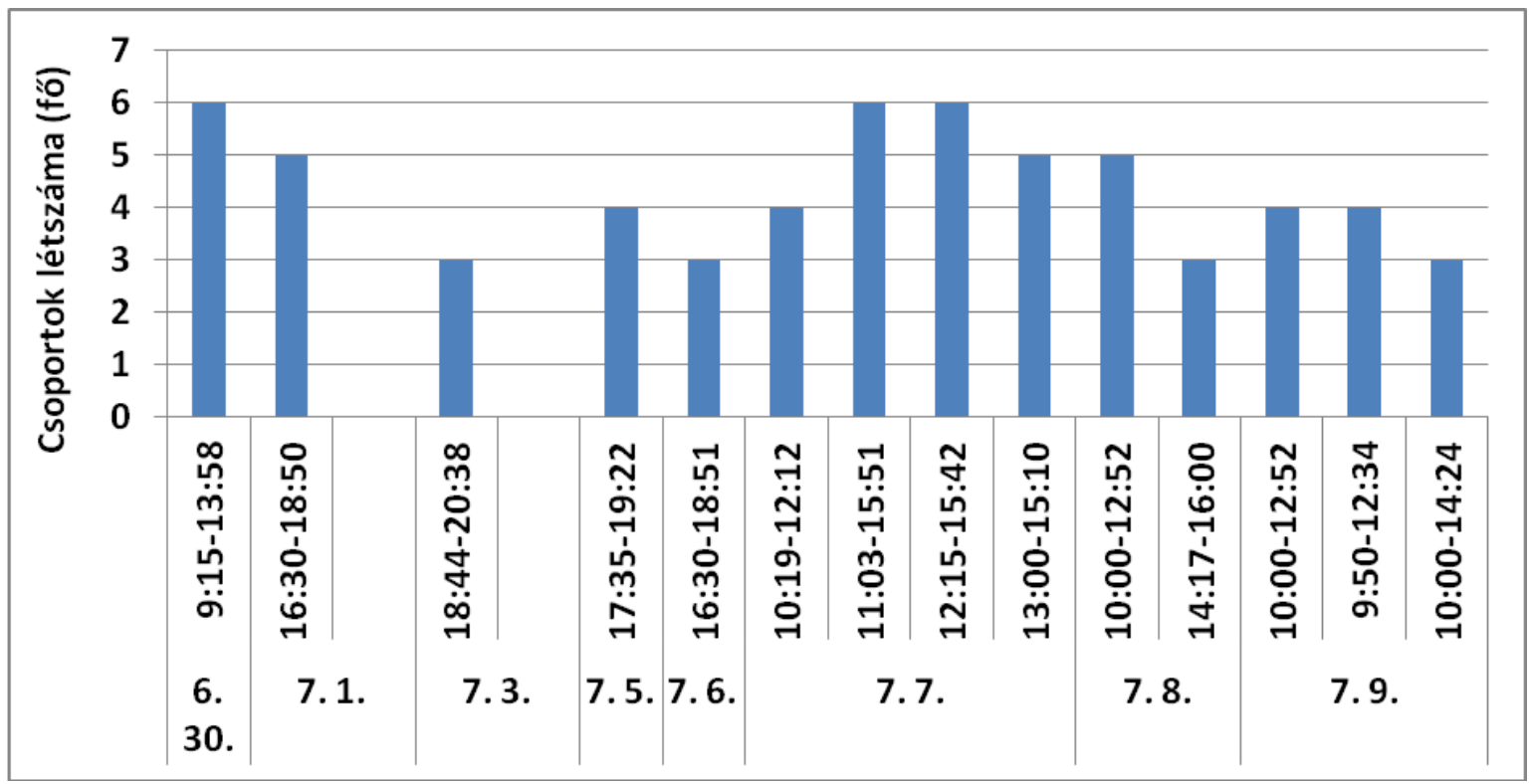

46. ábra A Hajnóczy-barlangba leszálló csoportok létszáma 2012.06.30-2012.07.09 között (Hajnóczy József Barlangkutató Csoport kutatásvezetője által feljegyzett adatok alapján)

A 2012-es nyári méréseink alapján $8,2-11,2{ }^{\circ} \mathrm{C}$ között oszlik el a hőmérséklet. A $8,2{ }^{\circ} \mathrm{C}$-os hömérsékletet a bejárati zónában a Niagara tetején rögzítettük, míg a $11,2{ }^{\circ} \mathrm{C}$-ot az Óriás-teremben. Az 1975-77 között megállapított értékhez képest $\left(8,5-10,55^{\circ} \mathrm{C}\right)$ negatív és pozitív anomáliát is tapasztalunk. A pozitív anomália annak köszönhető, hogy az 1975-77 közötti nyarakon a havi átlaghömérséklet $20,6-22{ }^{\circ} \mathrm{C}$ között változott, ezzel szemben a 2012-es év júliusi átlaghőmérséklet $24,1^{\circ} \mathrm{C}$ volt. Ez a tartós hőmérsékletemelkedés a barlangban is megmutatkozik, $0,65^{\circ} \mathrm{C}$-kal kitolódik a barlangban mérhető maximális hőmérséklet. 


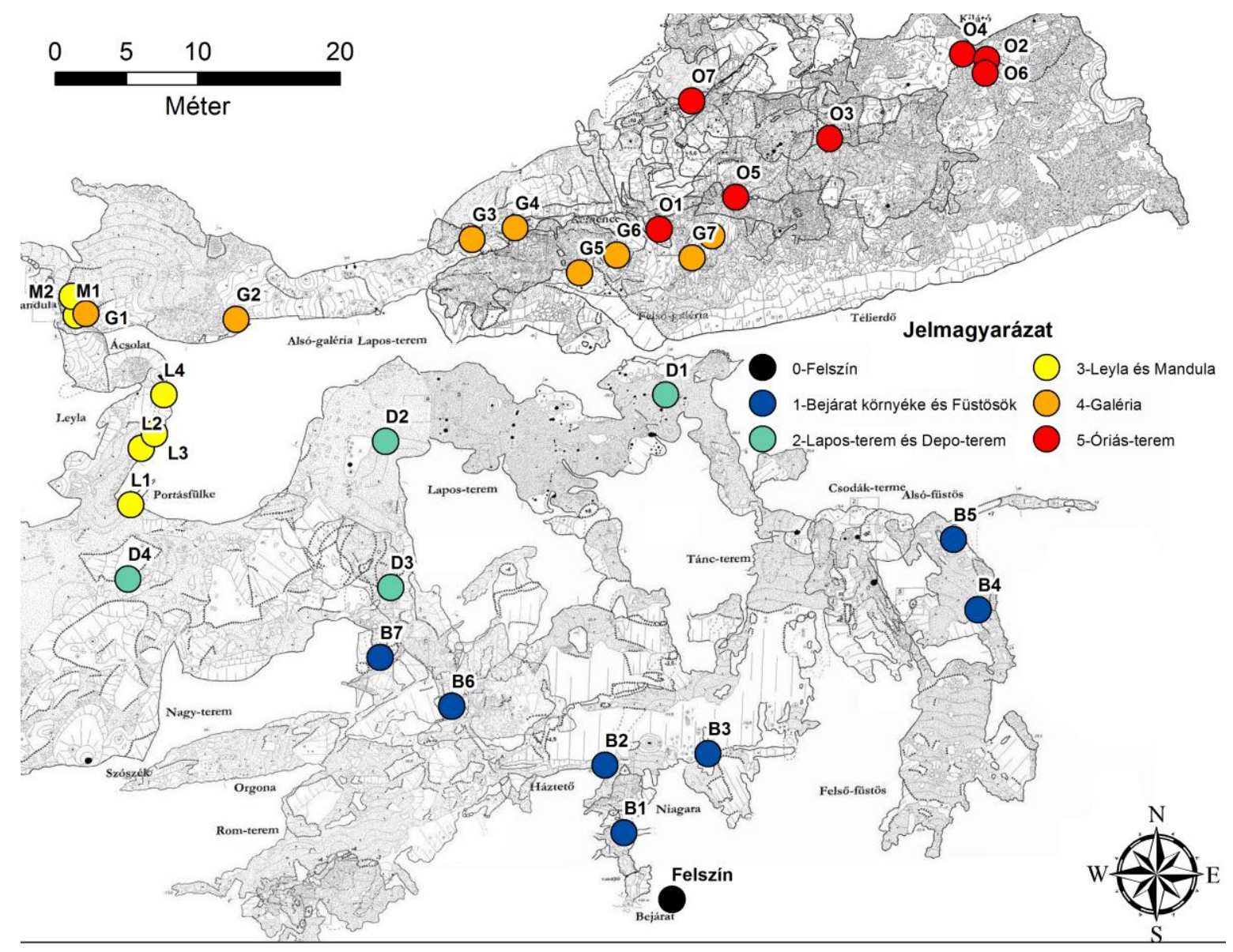

47. ábra A Hajnóczy-barlang nyári mérése során elhelyezett szenzorok 2012-ben

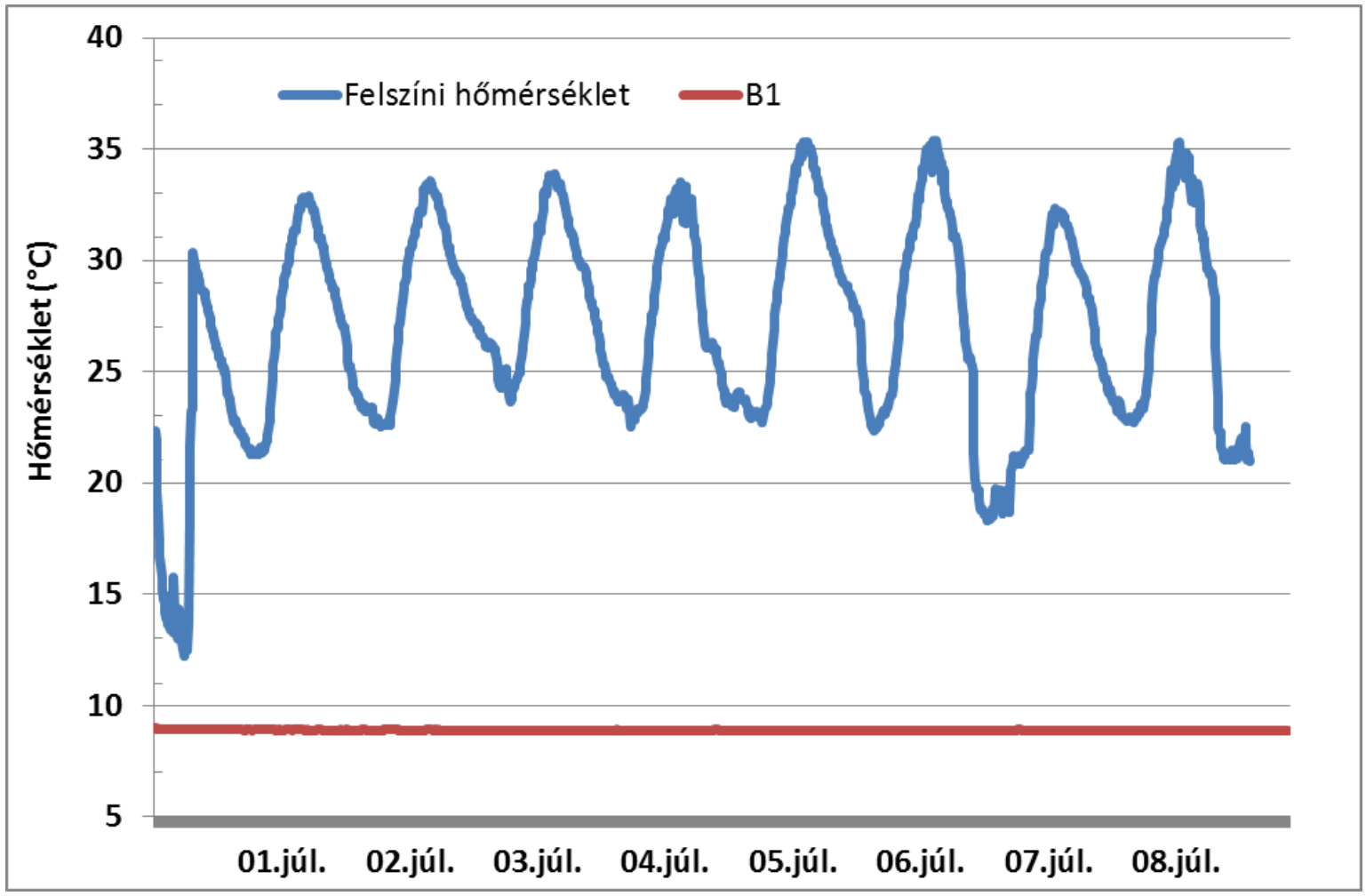

48. ábra A Felszín és a Bejárat (B1) hőmérséklete 
A felszínen elhelyezett szenzor adatairól (48. ábra) is jól látszódik, hogy a mérési időszakban a napi maximum adatok $33-35^{\circ} \mathrm{C}$ között, míg a napi minimum adatok $13-$ $23{ }^{\circ} \mathrm{C}$ között változnak.

A barlang bejárata az Odorvár oldalán nyílik, nyári légkörzés idején a bejárat teljes keresztmetszetén a szabadba áramlik a levegö. A bejárat környékén elhelyezett szenzorok esetében (B1-B7) a felszíni napi hőingás alig mutatható ki nyári légkörzés esetén, a barlangból kiáramló levegő a meghatározó. A bejárat akna jellege miatt barlangi légtömeg vertikális rétegzettsége is megjelenik az adatsoron, ahogy egyre mélyebbre haladunk a barlangban. Közvetlen a bejárat utáni elhelyezett B1 szenzor esetében (48. ábra) a hőmérséklet $8^{\circ} \mathrm{C}$. A következő B2 és B3 szenzorok 5-5 m-rel bentebb helyezkednek el, itt is erőteljes kifelé áramló levegő érvényesül. (49. ábra).

A légáramlás mértéke ezen a szakaszon olyan intenzív, hogy a barlangba látogató csoportok (46. ábra) hatását elnyomja a barlangi léghőmérséklet.

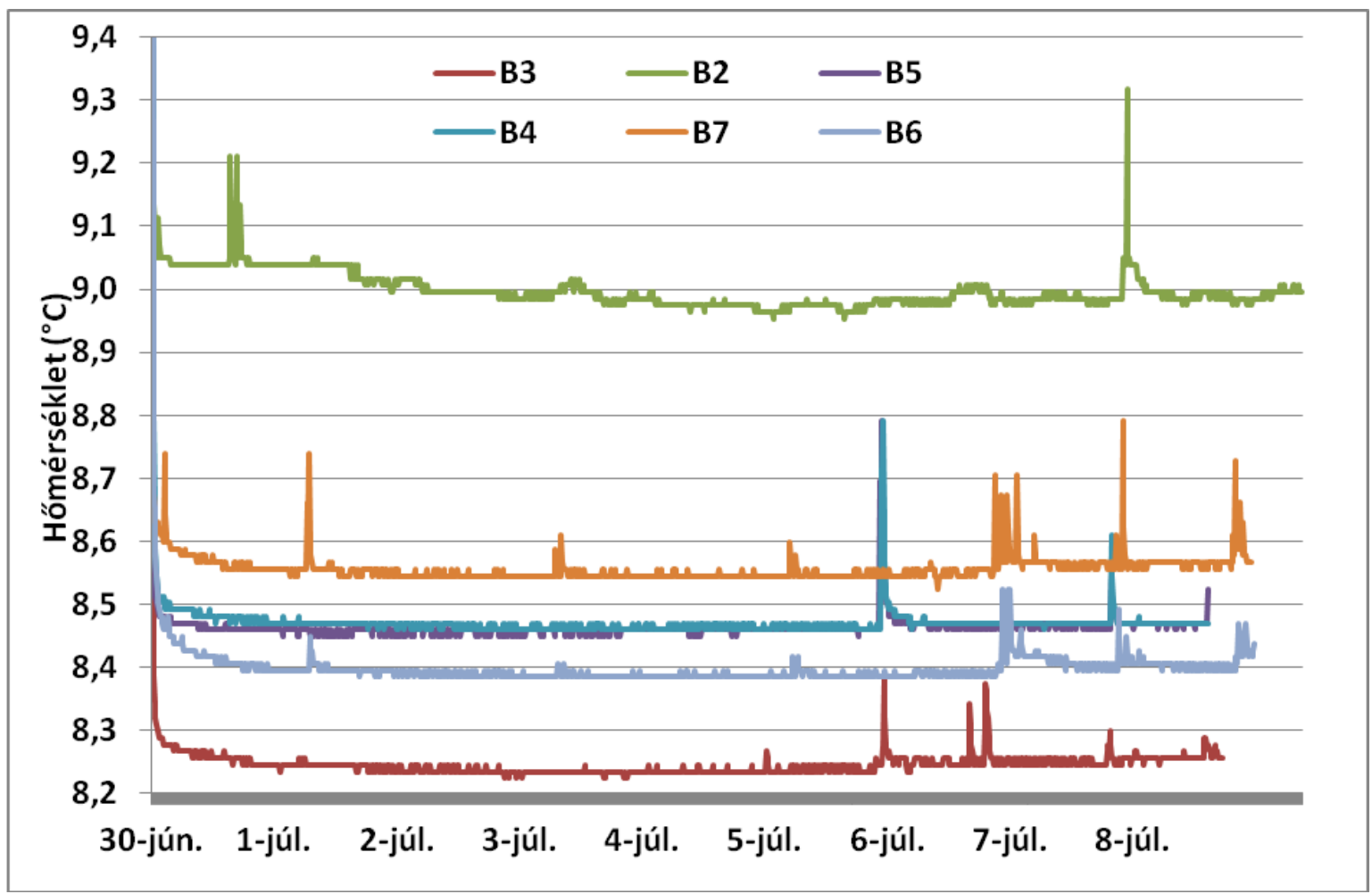

49. ábra A Bejárat környéke (B2-B3), Füstösök (B4-B5), Rom-terem (B6-B7) 2012. 06.30-07.08.

A Füstösök a bejárat körüli labirintus félreeső járat-rendszerei, melyek a nevüket a falaikon képződött fekete füstszerü anyagról kapták. A Füstösök járatait két részre oszthatjuk (49. ábra) az Alsó-Füstösökre (B5) és Felső-Füstösökre (B4). Az Alsó- 
Füstösben, és a Felső-Füstösben is $8,5^{\circ} \mathrm{C}$ körüli hőmérséklet volt. A július 6-án 3 barlangkutató okozta $0,3{ }^{\circ} \mathrm{C}$ léghőmérséklet-emelkedés két óra alatt csengett le mivel ezen szakaszon a nyári légkörzés esetén nem érzékelhető légmozgás. A július 8-i 3 fös csoport $0,1{ }^{\circ} \mathrm{C}$-os emelkedést okozott, mely 1 óra alatt csengett le Az antropogén hatás mértékét a teremben tartózkodás ideje is befolyásolja, ennek köszönhető a két csoport közötti eltérés.

A Rom-terem a bejárati zóna és a Depó-terem között helyezkedik el (47. ábra), mintegy átmeneti zónát képez a két szakasz között. A teremben két szenzort helyeztünk el (B6-B7), melyek értéke $8,4-8,55^{\circ} \mathrm{C}$ között változott. A csoportok nagy része áthaladt ezen a termen, így 3 és 6 fös csoportok okozta anomália is látható az adatsoron.

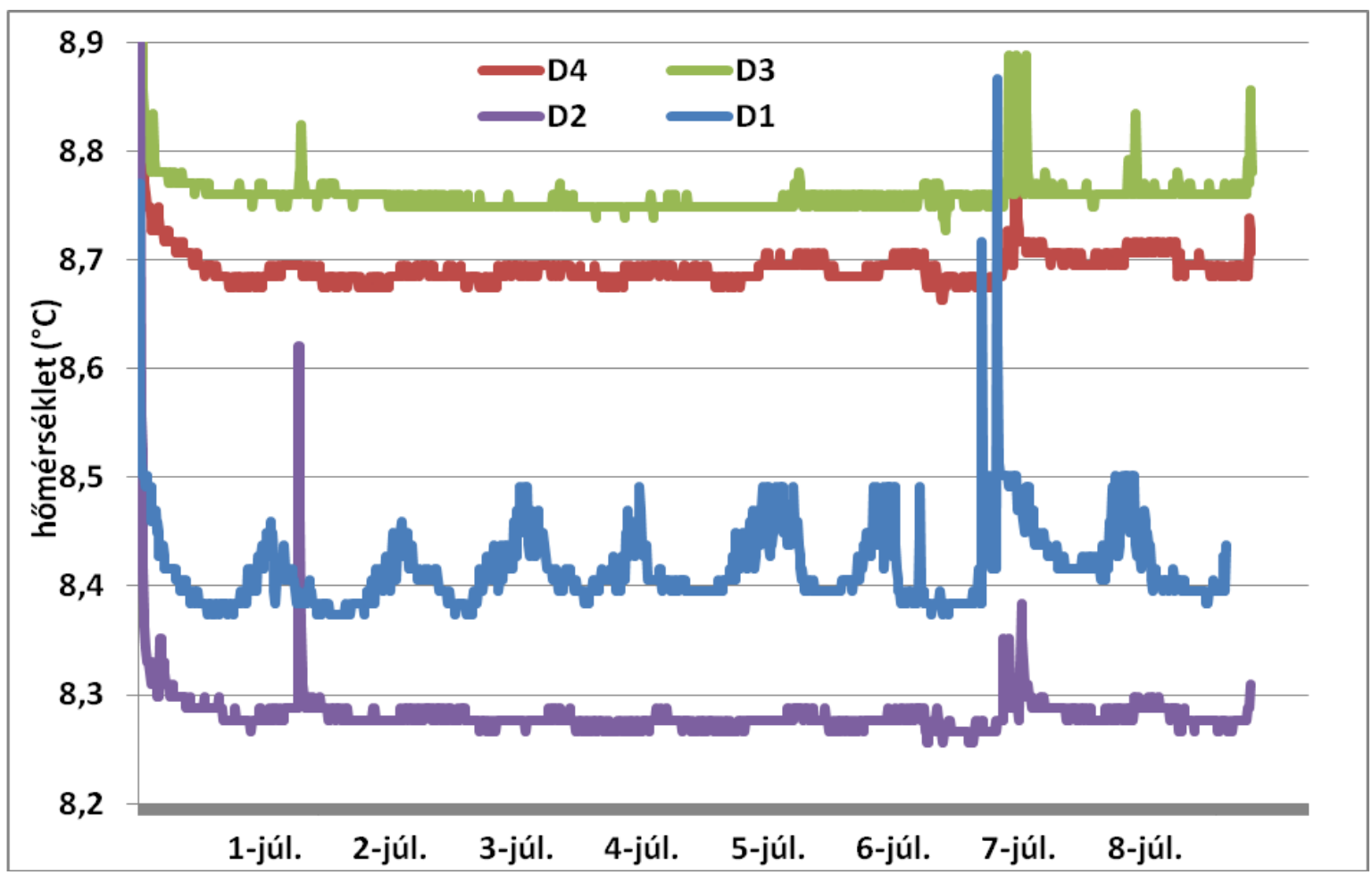

50. ábra A Lapos-terem (D1) Depó (D2,D3) és a Nagy-terem (D4) hőmérséklet adatai 2012.06.3007.08

A Lapos-teremben (50. ábra D1) a felszíni napi hőingás láthatóvá válik, mely $8,38-8,5^{\circ} \mathrm{C}$ között változik. Az adatsoron alig látható, hogy az Füstösökben tartózkodó csoport ezen az útirányon haladt keresztül július 6-án, csak $0,1^{\circ} \mathrm{C}$-os az emelkedés. A Hajnóczy József Barlangkutató Csoport kutatásvezetője által feljegyzett adatok alapján (46. ábra) július 7-én összesen 4 csoport indult a barlangba különböző időpontokban, ezek közül 2 csoport járt a Lapos-teremben 4-6 fővel. Az első csoport esetén $0,3{ }^{\circ} \mathrm{C}$-os emelkedés figyelhető meg, míg a második csoport esetén $0,45^{\circ} \mathrm{C}$. A csoport okozta hőtöbblet 40 és 30 percen belül áll 
vissza az eredeti állapotába, a napi ingás okozta napi maximum csak a csoport után mutatkozik.

A nyári mérés során elhelyeztünk a Depó-terem tetején (D3), illetve a Depó-terem alján (D2) egy-egy műszert (47. ábra), melyek segítségével meghatároztuk a terem vertikális hőmérséklet rétegződésének különbségét, melyet $0,5^{\circ} \mathrm{C}$-ban állapítottunk meg. A terem alján (D2) $8,3{ }^{\circ} \mathrm{C}$, míg a terem tetején $8,8{ }^{\circ} \mathrm{C}$-ot mutattunk ki (D3). A Nagy-terem 48 m hosszú és 14 méter széles, magassága 5-8 m. A Nagy-teremben elhelyezett szenzor (D4) hasonló relatív magasságban lett elhelyezve, mint a Depó-terem teteje, viszont ebben a pontban jobban megfigyelhető a napi ritmus. A Depó-teremben július 1-én délután 5 fó tartózkodott, a terem alján elhelyezett müszer környékén, ez $0,3^{\circ} \mathrm{C}$-os emelkedést mutat, mely kb.20 perces ott tartózkodással alakult ki, és ez 1 óra 20 perc alatt állt vissza az eredeti állapotába. A terem tetején lévő $0,1^{\circ} \mathrm{C}$-os emelkedést mutat, mely 10 perc ott tartózkodással alakult ki, és 20 perc lecsengési idővel tért vissza nyugalmi szintre.

A Nagy-teremből továbbhaladva a Leyla, majd a Mandula egyre szükülö keresztmetszetü folyosója biztosítja az összeköttetést a Galériával (47. ábra). Az eddigi méréseink (Muladi, et al., 2013b), és Miklós Gábor vizsgálatai alapján a Leyla és a Mandula szük keresztmetszete felerősíti a légáramlást. Ezen a szakaszon az évi hőmérséklet menetét, illetve a napi ingást is láthatjuk, és téli légkörzés idején sokkal intenzívebb.

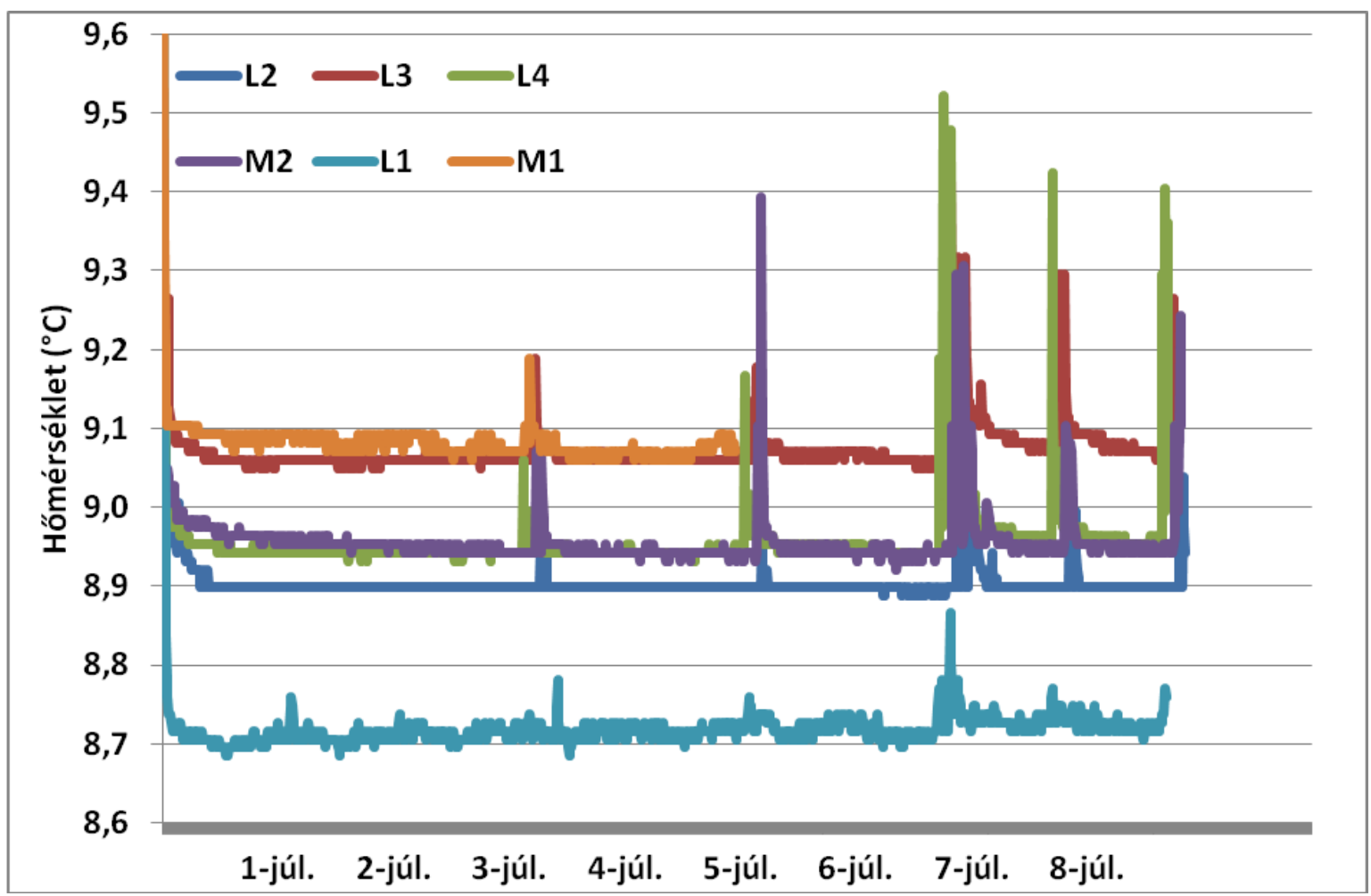

51. ábra A Leyla (L1, L2,L3,L4) és a Mandula (M1,M2) hőmérséklet adatai 2012. 06.30-07.08. 
A Leylában és Mandulában elhelyezett müszerek hőmérséklet adatai $8,7-9,1^{\circ} \mathrm{C}$ között oszlik meg (51. ábra). A Portásfülkében (L1) elhelyezett szenzort légáramlás szempontjából védettebb helyre tudtuk elhelyezni, de a látogatók hatása még így is látszódik, ha csak minimálisan is.

A többi helyszín esetében $0,1-0,2{ }^{\circ} \mathrm{C}$-os változások láthatók, a legintenzívebb hőmérséklet-emelkedés a Leyla utolsó pontjánál (L4), illetve a Mandula szükületben (M2) volt. A két utóbbi pontot (L4, M2) részletesebben elemezve az alábbi hatások láthatók: július 3-án 3 fö indult a Jubileumba, ez $0,1^{\circ} \mathrm{C}$-os emelkedést eredményezett mindkét helyen. A következő Leylán és Mandulán áthaladó túra július 5-én volt a Komszomol irányába. A 4 fós csoport a Leylánál $0,2{ }^{\circ} \mathrm{C}$-kal, a Mandulánál $0,4{ }^{\circ} \mathrm{C}$-kal változtatta meg a hőmérsékletet. A legtöbb ember július 7-én haladt át ezen a barlangjáraton, ugyanis két túra volt az Óriás-terembe 6-6 fővel, valamint a Két-tóhoz 5 fővel. A 17 személy áthaladása 4,5 órán át tartó folyamatos hőingást okozott. A járat szük keresztmetszete azonban segíti a rendszer gyors helyreállását. Mind a két helyen 20 perc alatt emelkedett a maximumára a hőmérséklet, a Leylánál $0,6^{\circ} \mathrm{C}$, a Mandulánál $0,4^{\circ} \mathrm{C}$, ezután 40 perc alatt csengett le.

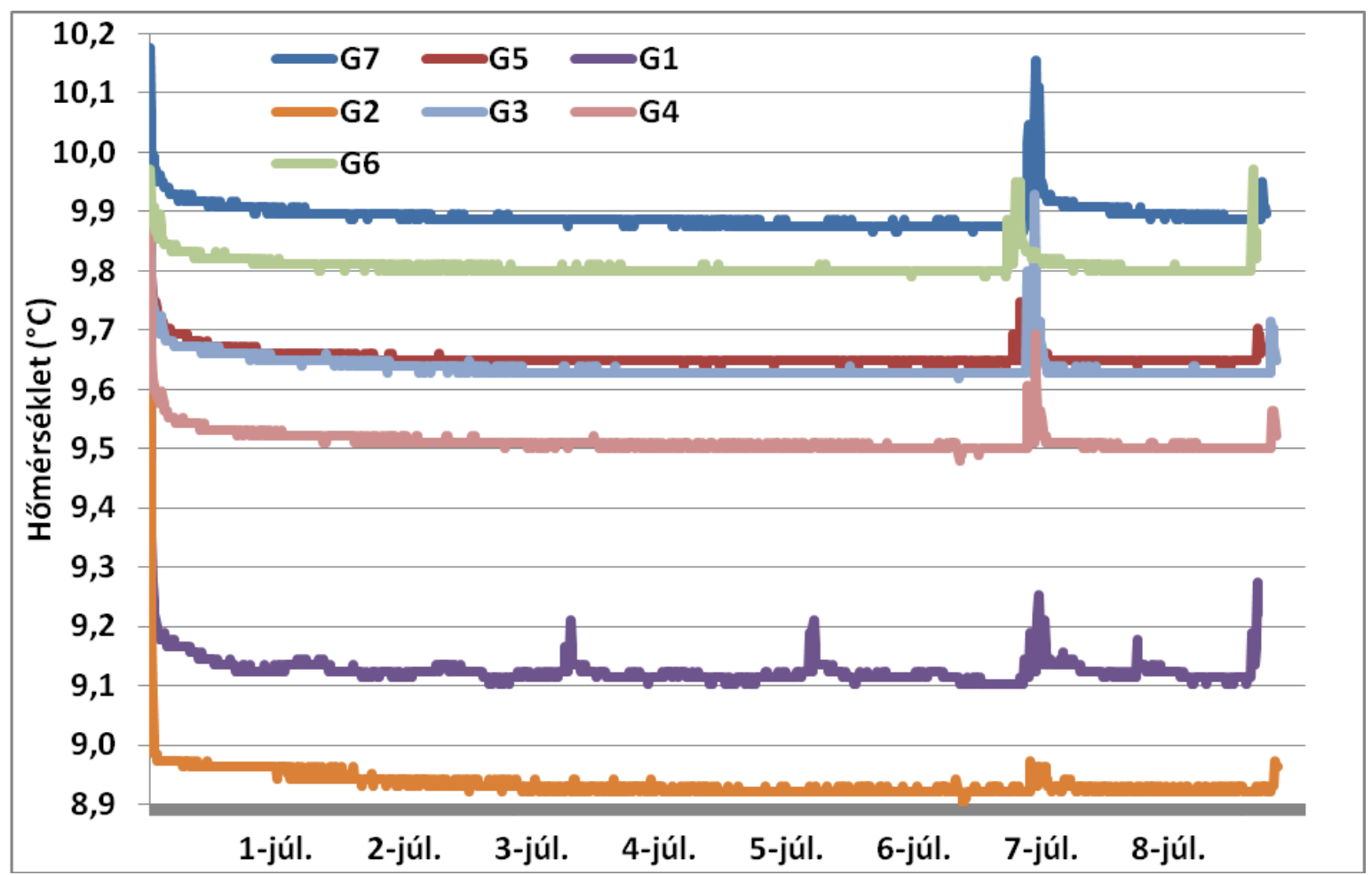

52. ábra Az Alsó-Galéria (G1,G2), és a Felső Galéria (G3,G4,G5,G6,G7) hőmérséklet adatai 2012. 06.30-07.08. 
Cseppkövekben rendkívül gazdag a Galéria, amely 70 m hosszú, 1-8 m széles, s magassága 4-13 m. Miklós Gábor (1978) ebben a teremben 9,7 ${ }^{\circ} \mathrm{C}$-ot regisztrált 1975 nyarán. Az irodalomban az nem szerepel, hogy a terem mely keresztmetszetében, milyen magasságban történt ez a mérés. A 2012-es mérés alapján ezt az értéket még pontosabban tudtuk meghatározni a terem különböző pontjain. Az Alsó- és Felső- Galériában elhelyezett müszerek (47. ábra) adatai alapján (52. ábra) látszódik, hogy a barlang levegője termenként stabilan rétegződik. Az Alsó-Galériában elhelyezett szenzorok G1 $\left(9,1{ }^{\circ} \mathrm{C}\right.$, tszf. $443 \mathrm{~m})$, és $\mathrm{G} 2\left(8,9^{\circ} \mathrm{C}\right.$, tzsf. $\left.440 \mathrm{~m}\right)$ közül az utóbbi volt alacsonyabb helyen, ami látható az adatsoron is (52 ábra). A Felső-Galériában kifeszítettünk egy kötelet és annak mentén füztük fel a G3, G5szenzorokat, melyek hőmérséklete: $9,65^{\circ} \mathrm{C}$, tszf. 453 m. A G4es szenzor a medvecsontok mellett helyeztük el, mely 449 m-en volt $\left(9,5^{\circ} \mathrm{C}\right)$. Az Óriásterem felé tovább haladva helyeztük el a G6 és G7-es szenzort, 456 és 460 m-es magasságban $\left(9,8-9,9^{\circ} \mathrm{C}\right)$.

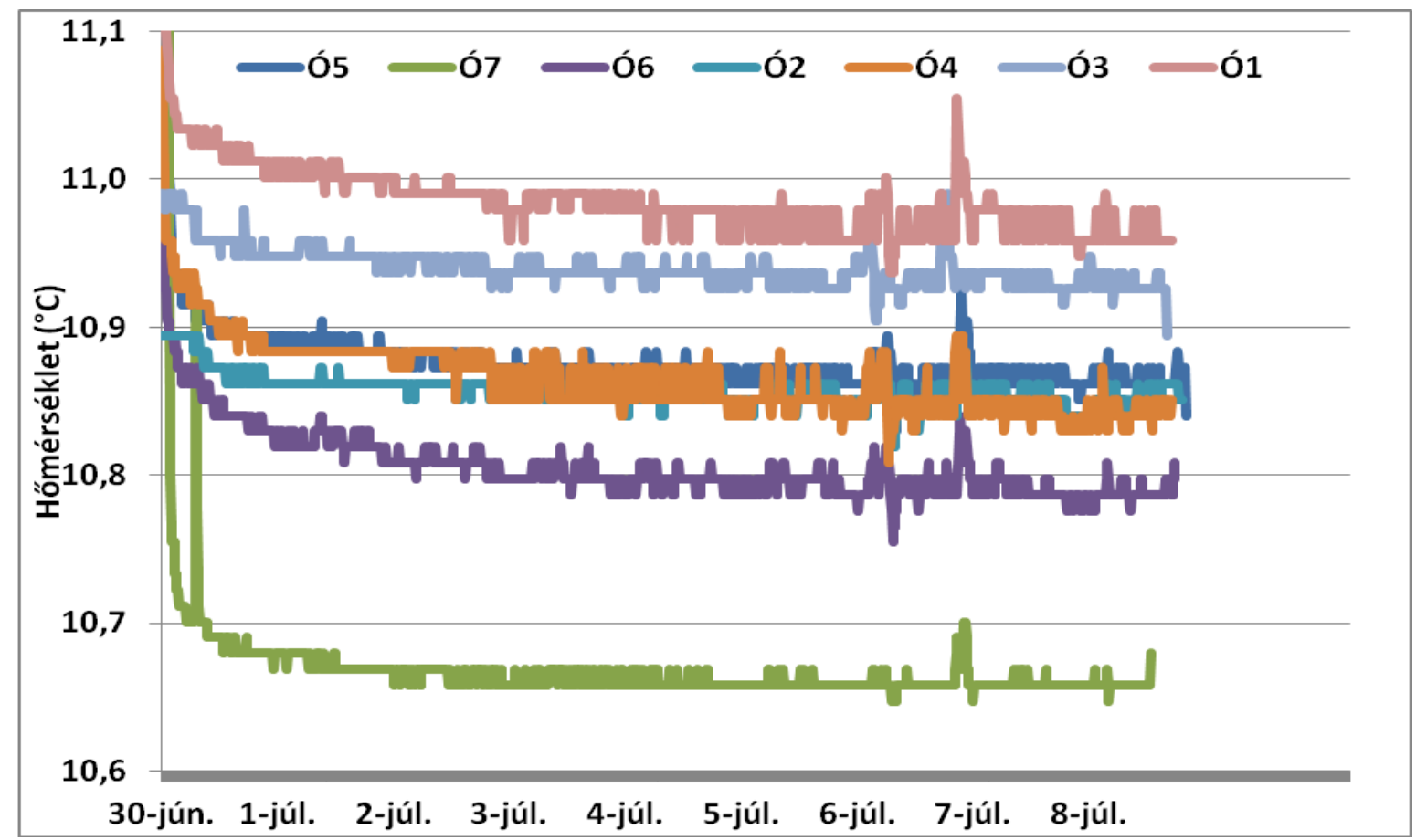

53. ábra Az Óriás-terem hőmérséklet adatai (Ó1-Ó7) 2012. 06.30-07.08.

A csoportok okozta hőmérséklet-emelkedés alapján elmondható, hogy a szük járatú Mandula után elhelyezett szenzornál (G1) még tapasztalható a Mandula által felgyorsított légtömeg, mivel a napi ritmus minimálisan észlelhető. A csoportok is itt kerültek a legközelebb a szenzorhoz, így látszódik az áthaladásuk $0,1{ }^{\circ} \mathrm{C}$-os hőingással. A Galéria 
hatalmas térfogata ellenére is változások láthatók, a július 7-i 3 csapat hatása. A hőmérsékleti anomália $0,15-0,3{ }^{\circ} \mathrm{C}$ között változik.

A Galéria keleti végéből, beomlott több tonnás sziklatömbök között lehet feljutni a 63 m hosszú, $14 \mathrm{~m}$ magas és $16 \mathrm{~m}$ széles Óriás-terembe. Mennyezetéről több helyen gyökerek lógnak alá. Jelenleg ez a terem a barlang legszárazabb része, de a múltban nem lehetett így, mert hatalmas, ma száraz cseppkőképződmények díszítik.

12. táblázat A Hajnóczy-barlang különböző szakaszainak hőterhelése adott csoportlétszám hatására

\begin{tabular}{|c|c|c|c|c|c|c|c|}
\hline & $\begin{array}{l}\text { Tszf. } \\
(\mathrm{m})\end{array}$ & $\begin{array}{c}\mathbf{A} \\
\left(\mathbf{m}^{2}\right)\end{array}$ & $\begin{array}{l}\mathbf{T}_{\text {átlag }} \\
\left({ }^{\circ} \mathbf{C}\right)\end{array}$ & $\begin{array}{c}\mathbf{6} \text { fö } \\
\Delta \mathrm{T}\left({ }^{\circ} \mathrm{C}\right) \\
\end{array}$ & $\begin{array}{c}5 \text { fö } \\
\Delta \mathbf{T}\left({ }^{\circ} \mathrm{C}\right) \\
\end{array}$ & $\begin{array}{c}4 \text { fó } \\
\Delta \mathrm{T}\left({ }^{\circ} \mathrm{C}\right) \\
\end{array}$ & $\begin{array}{r}3 \text { fó } \\
\Delta \mathrm{T}\left({ }^{\circ} \mathrm{C}\right) \\
\end{array}$ \\
\hline B1 & 457 & 0,58 & 8 & 0 & 0 & 0 & 0 \\
\hline B2 & 454 & 0,6 & 9,1 & 0,3 & 0,3 & 0,2 & 0 \\
\hline $\mathbf{B 3}$ & 454 & 8 & 8,25 & 0,15 & 0,15 & 0,12 & 0,05 \\
\hline B4 & 431 & 0,8 & 9,46 & - & - & 0,2 & 0,3 \\
\hline B5 & 428 & 0,7 & 9,46 & - & - & 0,2 & 0,3 \\
\hline B6 & 442 & 9 & 8,39 & 0,12 & 0,1 & 0,12 & 0,07 \\
\hline B7 & 441 & 0,7 & 8,55 & 0,15 & 0,2 & 0,15 & 0,05 \\
\hline D1 & 431 & 3,8 & 8,45 & 0,36 & 0,2 & 0,1 & - \\
\hline D2 & 430 & 3,8 & 8,3 & 0,1 & 0,3 & 0,1 & 0,1 \\
\hline D3 & 435 & 5,5 & 8,75 & 0,1 & 0,1 & 0,05 & 0,05 \\
\hline D4 & 436 & 21 & 8,69 & - & - & - & - \\
\hline L1 & 434 & 4,7 & 8,7 & 0,1 & 0,1 & 0,05 & 0,06 \\
\hline L2 & 434 & 3,14 & 8,9 & 0,2 & 0,13 & 0,1 & 0,05 \\
\hline L3 & 435 & 3,1 & 9,07 & 0,32 & 0,22 & 0,14 & 0,11 \\
\hline L4 & 435 & 2 & 8,95 & 0,45 & 0,4 & 0,2 & 0,12 \\
\hline M1 & 437 & 0,5 & 9,09 & - & - & - & 0,1 \\
\hline M2 & 439 & 0,6 & 8,95 & 0,4 & 0,4 & 0,5 & 0,1 \\
\hline G1 & 443 & 51,81 & 9,1 & 0 & 0 & 0 & 0 \\
\hline G2 & 440 & 20,41 & 8,9 & 0,13 & 0,1 & 0,1 & 0,1 \\
\hline G3 & 453 & 40,5 & 9,65 & 0,27 & 0,17 & 0,08 & - \\
\hline G4 & 449 & 50,24 & 9,5 & 0,43 & 0,2 & 0,05 & - \\
\hline G5 & 453 & 50,24 & 9,65 & 0,1 & 0,04 & 0,04 & - \\
\hline G6 & 456 & 15 & 9,8 & 0,14 & 0,12 & 0,09 & - \\
\hline G7 & 460 & 1,57 & 9,9 & 0,25 & 0,17 & 0,18 & - \\
\hline
\end{tabular}

Ismét az 1975-ös méréssel összehasonlítva az Óriás-teremben $10,4{ }^{\circ} \mathrm{C}$-ot rögzítettek, a 2012-es adatok alapján (53. ábra) ez az érték $10,67-11{ }^{\circ} \mathrm{C}$ között változik, amely intervallum magasabb értékekkel rendelkezik, mint a korábbi években rögzített. Ez az 
eltérés azt jelezheti, hogy a nyári nagy melegek hatására a talaj és a vékony mészkőréteg jobban átmelegedett. . Ez problémát okozhat, mert az extrém magas hőmérséklet és a kevés csapadékkal rendelkező nyarak a barlang legnagyobb kiterjedésű egybefüggő cseppkőlefolyásának - egy természeti kinccsé vált képződménynek - a Télierdőnek a degradációját is elindíthatják.

A mérés érdekessége még, hogy a barlang legnagyobb termében tartózkodó 12 fö, ha csak minimális hömérséklet-emelkedést is okozott, mégis láthatóvá válik az adatsoron, annak ellenére, hogy a szenzorok nem a közvetlen környezetükben voltak, hanem a barlangterem két távolabbi pontjában egy horizontálisan kifeszített 20 m-es kötélen lógtak.

\subsubsection{Az antropogén hatás mértéke a Trió-barlangban}

Az időszakos megfigyeléseknél már bemutattam a Trió-barlang 2012.04.192012.06.16 közötti általános változásait, most ezen időszak antropogén hatásának vizsgálatát mutatom be. A 12 db mérőmüszer (19. ábra) a bejárati szakasztól kezdve az akna soron át a két végponton is mért. Az adatsoron a 10 percenként rögzített hömérsékletváltozások jelennek meg (54. ábra). A vizsgálati időszakban 243 fö fordult meg a barlangban mind kutatási, mind pedig túrázási céllal.

Az adatokon látszódik, hogy nem minden müszer mért a vizsgálati időintervallum végéig. Ez annak tudható be, hogy ebben az időben rengeteg csapadék zúdult a Mecsekre, a vizsgálati időszakban a Pécsi meteorológiai állomás adatai alapján $210 \mathrm{~mm}$ csapadék volt. A Szuadó-völgyben összegyülő víz a víznyelő barlangokban talált utat, valamint a karsztvízszint emelkedését is okozhatta. Azok a műszerek, amelyeket nem ért víz jól müködtek, és látható rajtuk a csoportok okozta hőmérséklet-emelkedés.

Mielőtt a látogatócsoportok hőterhelését elemezném, néhány szót arról, hogy milyen természetes hőmérsékletváltozások voltak jellemzőek a vizsgált időszakban. Május 23-án hullott a legtöbb csapadék $83 \mathrm{~mm}$. Hőmérséklet csökkenés figyelhető meg az Örszemteremben $\left(-0,28^{\circ} \mathrm{C}\right)$, és az Elágazásnál $\left(-0,32^{\circ} \mathrm{C}\right)$, ami az e szakaszon felbukkanó vízfolyásnak tudható be (54. ábra). Ez a Vizes-ági szakasza a barlangnak, ahol csapadékosabb időszakokban a szilvamag alakú járat aljában általában csörgedezik a víz, illetve a karsztvíz rendszerint alulról is feltölti a barlang járatait. 2010-ben fordult elö, hogy a rendkívüli csapadék maximum hatására a völgyben hömpölygő megáradt patak felülről töltötte a barlangot, illetve a karsztvízszint emelkedéssel együtt a teljes barlangot kitöltötte a víz (Muladi, 2011). Többször megfigyeltük már kutatótársaimmal a járatok 
falára kirakodó üledéket, mely pontosan mutatja, meddig emelkedik meg a karsztvízszint, és ez általában jól látható nyomokat hagyott a 3-as aknától a végpontokig is. A mostani mérésnél, mivel az Örszem-teremben is és az Elágazásánál is egy időben történt a $0,4{ }^{\circ} \mathrm{C}$ os hömérséklet csökkenés (54.ábra), és a kiegyenlítődési szakasz után is $0,1^{\circ} \mathrm{C}$-kal hüvösebb lett mind a két vizsgálati hely hőmérséklete, egyértelműsíthető a felszíni patak betörése. Ezzel egy időben a Búboskemence adatsorán is megfigyelhetö egy $0,1^{\circ} \mathrm{C}$-os hőmérséklet csökkenés, amely arra utalhat, hogy ott is megjelenhetett csapadékvíz.

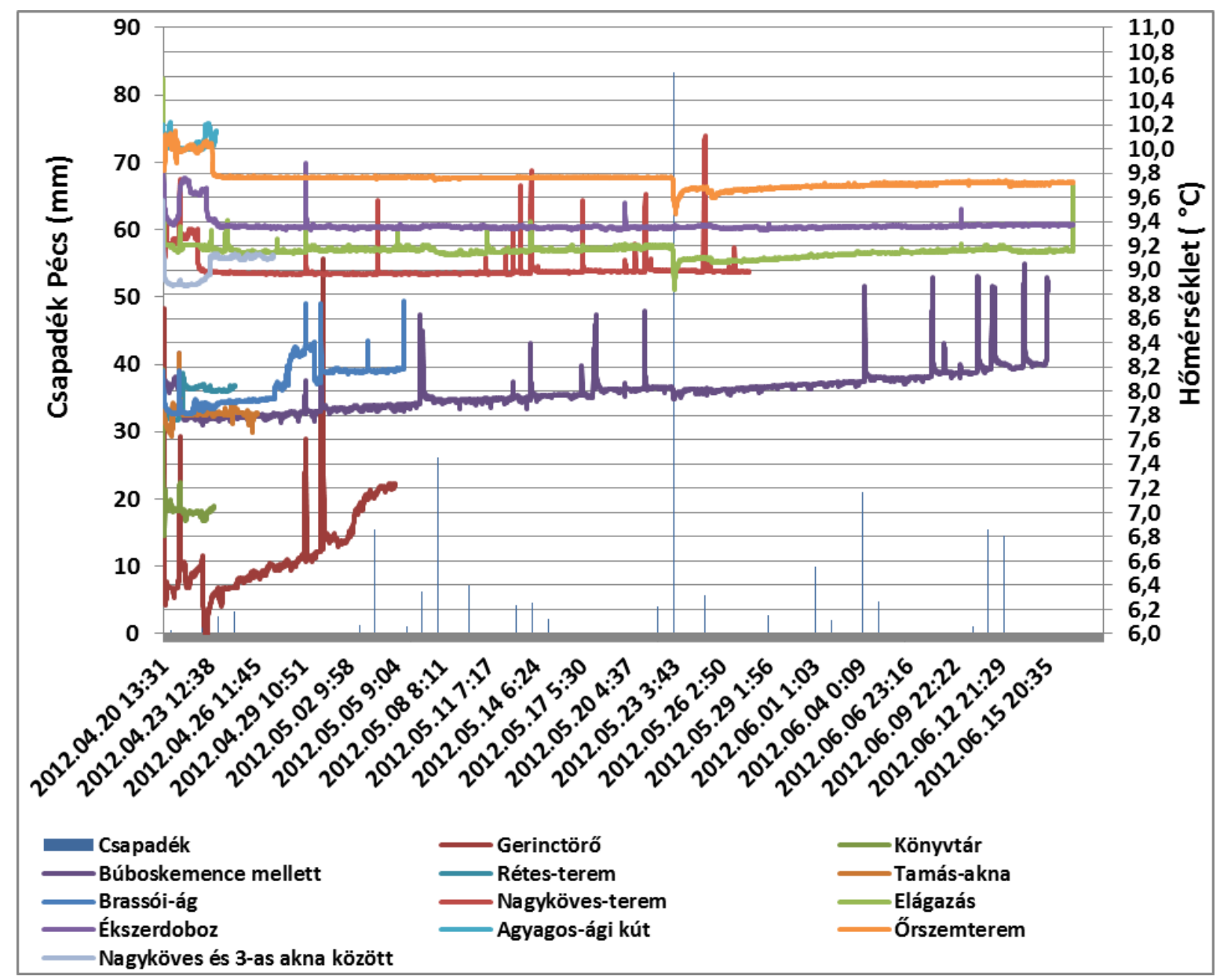

54. ábra A Trió-barlang hőmérsékletei és a Pécsi meteorológiai állomás csapadék adata 2012.04.20-2012.06.17 között

Az adott időszakban rögzítettük, hogy a csoportok mikor túráztak a barlangban és hányan voltak a csoportban. Az adatok alapján is látszódik, hogy a Nagyköves-teremig haladtak csak túrák, leszámítva két 3 fős csoportot, akik az Agyagos-ági Ékszerdobozig túráztak. Ezt a túravezetők is megerősítették. 
Kiemelném a Búboskemece mellett elhelyezett szenzor adatait, mivel itt a csoportok több időt töltenek el, míg a cseppkőképződmények mellett tovább haladnak. A Búboskemence adatsorán jól megfigyelhető a csoportok okozta hőmérséklet-emelkedés (55. ábra). Már a háromfős csoportok is kivehetők az adatsoron, ezek $0,1^{\circ} \mathrm{C}$-ot módosítanak a hőmérséklet adatokon (55. ábra). Amikor egy napon belül 28 kutató fordult meg a barlangban, akkor $0,7^{\circ} \mathrm{C}$-os hőmérséklet-emelkedés volt megfigyelhető. Ebben az esetben a 28 fó nem egyszerre tartózkodott lent a barlangban, hanem három csoportban mentek le (56. ábra), az első csoportban 10-en voltak, a másik két csoportban 9-9 fö tartózkodott a barlangban. Itt is látható, hogy a maximumot fél óra alatt eléri a hőmérséklet, és a visszahűlés 1 óra alatt történik meg.

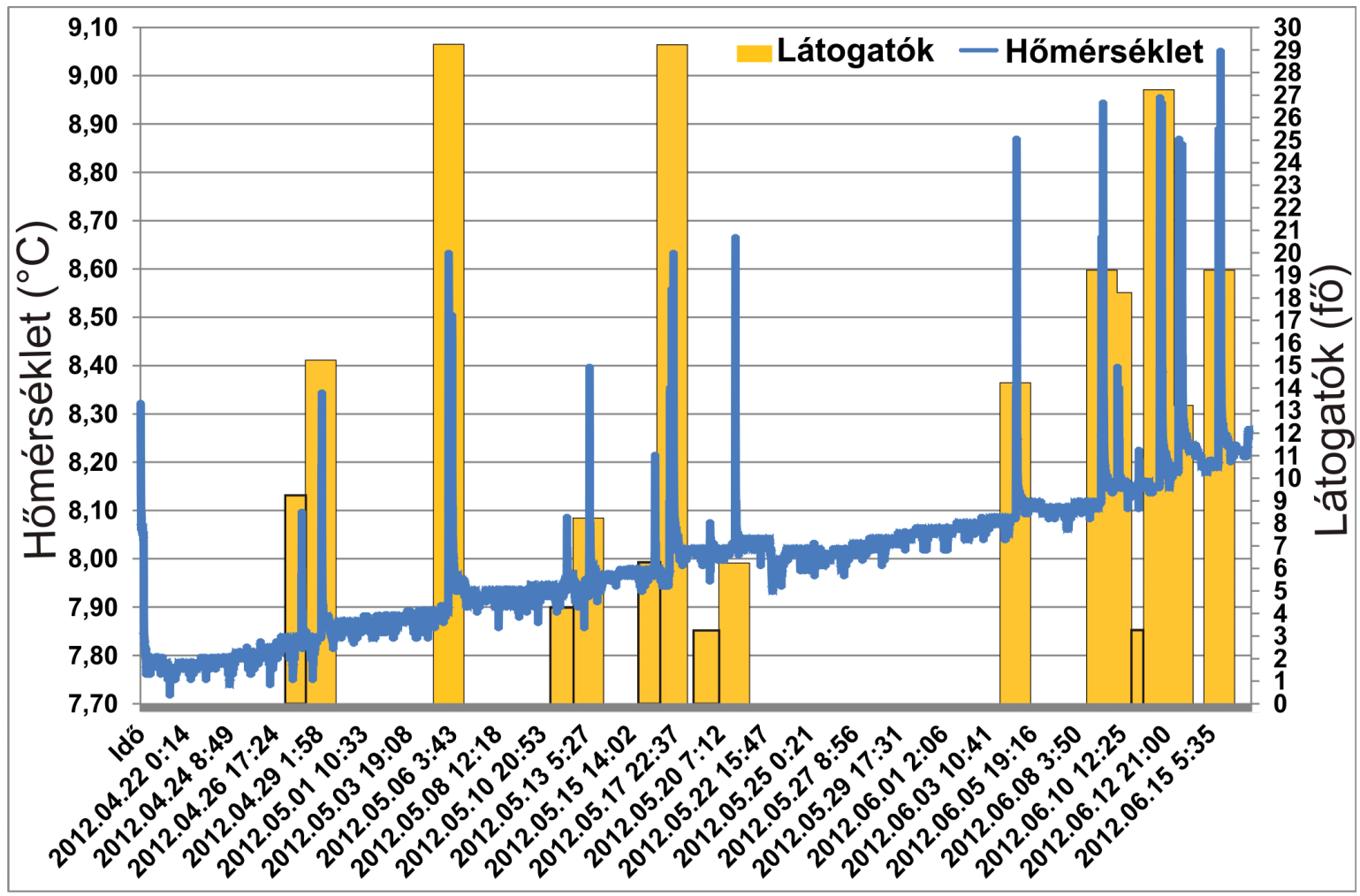

55. ábra A Búboskemence melletti szenzor adatai és a csoportlétszám

A két hónapig tartó mérés jól mutatja, hogy az 1. akna utáni szakaszon még a felszíni hatások minimálisan érződnek. A hőmérsékleti görbén látszódik a napi hőingás, ennek értéke átlagosan $0,05{ }^{\circ} \mathrm{C}$-os. A diagramon hőmérséklet-emelkedési trend figyelhető meg, ennek értéke $0,4{ }^{\circ} \mathrm{C}$ (55. ábra). Ezalatt a völgyben is egyre magasabbak lettek a napi átlaghőmérsékletek $\left(11^{\circ} \mathrm{C}\right.$-ról $16^{\circ} \mathrm{C}$-ra emelkedett a napi átlag). 


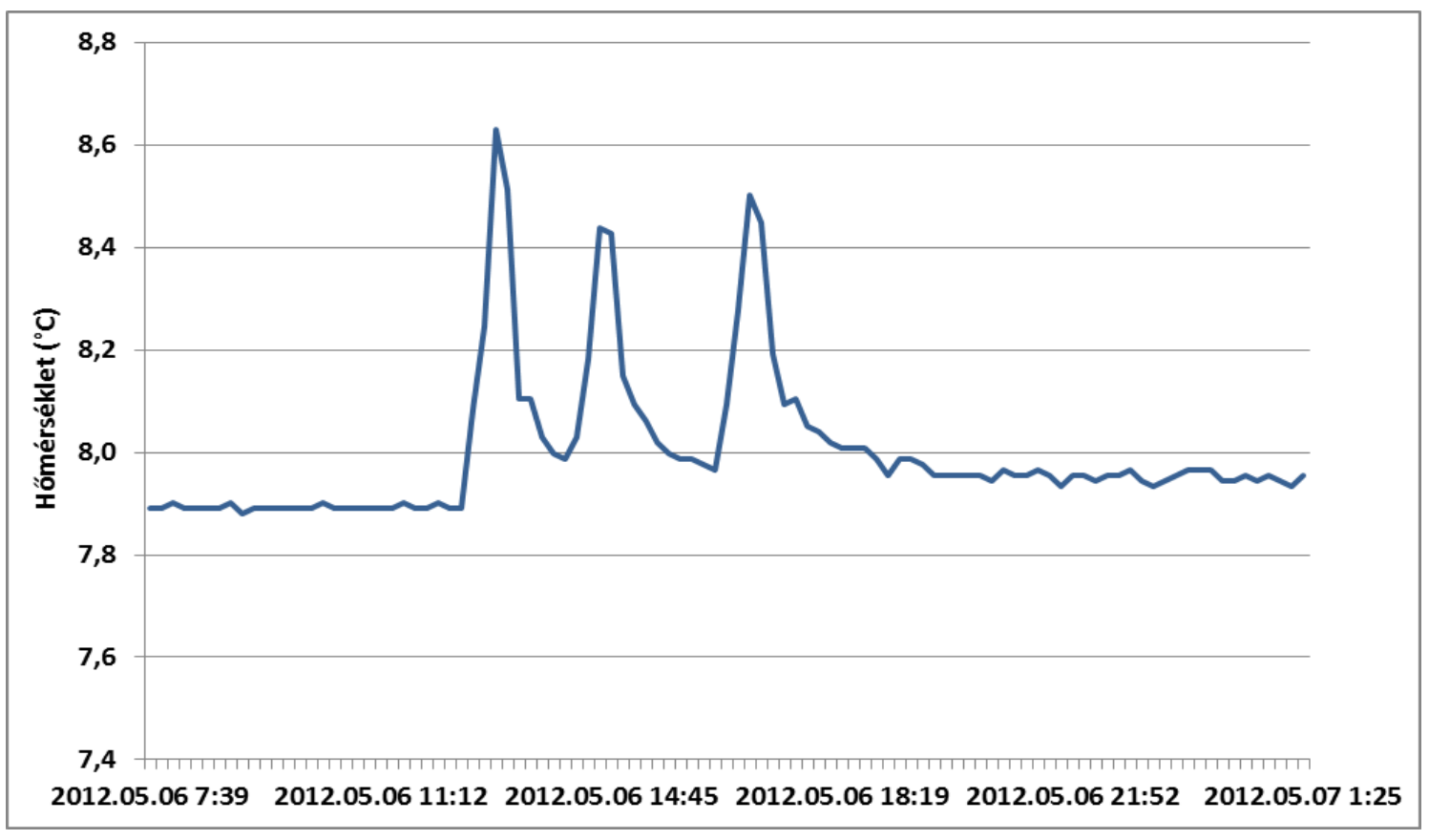

56. ábra A Búboskemencénél rögzített 3 kutatócsoport által okozott hőmérséklet-emelkedés 2012.05.06.

\subsubsection{Hideg-lyuk - Pecsétnyomó}

A Hideg-lyukban a kutatásoké a fő szerep, itt a kutatók a mintaterületi szakaszon föként csak áthaladtak, de volt egy mérési periódus 2013.10.22-12.06., között, amikor is a Pecsétnyomó utáni szakaszon bontották a IX-es aknát. Itt a müszer ugyan egy légtérben volt a kutatókkal, de 5 m-rel távolabb helyezkedett el a bontási ponttól. A vizsgált periódusban 72 fő fordult meg összesen a bontások alkalmával a Pecsétnyomónál.

Az esetek többségben $\mathrm{kb}$. 5 órát töltöttek itt mindig aktív aknajárat mélyítéssel, november 17-én viszont 7 órát töltöttek lent a bontásnál (57. ábra). A 8 fös kutatócsoport $1,25^{\circ} \mathrm{C}$-kal emelte meg a hőmérsékletet, míg 14 fö esetén $1,75^{\circ} \mathrm{C}$-kal emelkedett meg a hőmérséklet. A 8 fös hőmérséklet-emelkedésnél 2 óra alatt áll vissza a hőmérséklet $10,25{ }^{\circ} \mathrm{C}$-ra, míg a 14 fős bontás után 3,5 óra kellett, hogy a hőmérséklet ismét $10,25{ }^{\circ} \mathrm{C}$ alá essen.

A bontó müszakok sikeresek voltak, mert 12.08.-án belyukadtak a IX.-es aknába és 12.10-én 20 m-nyi új járatot jártak be. Ezután még egy kisebb terem is feltárásra került az akna alatt. 


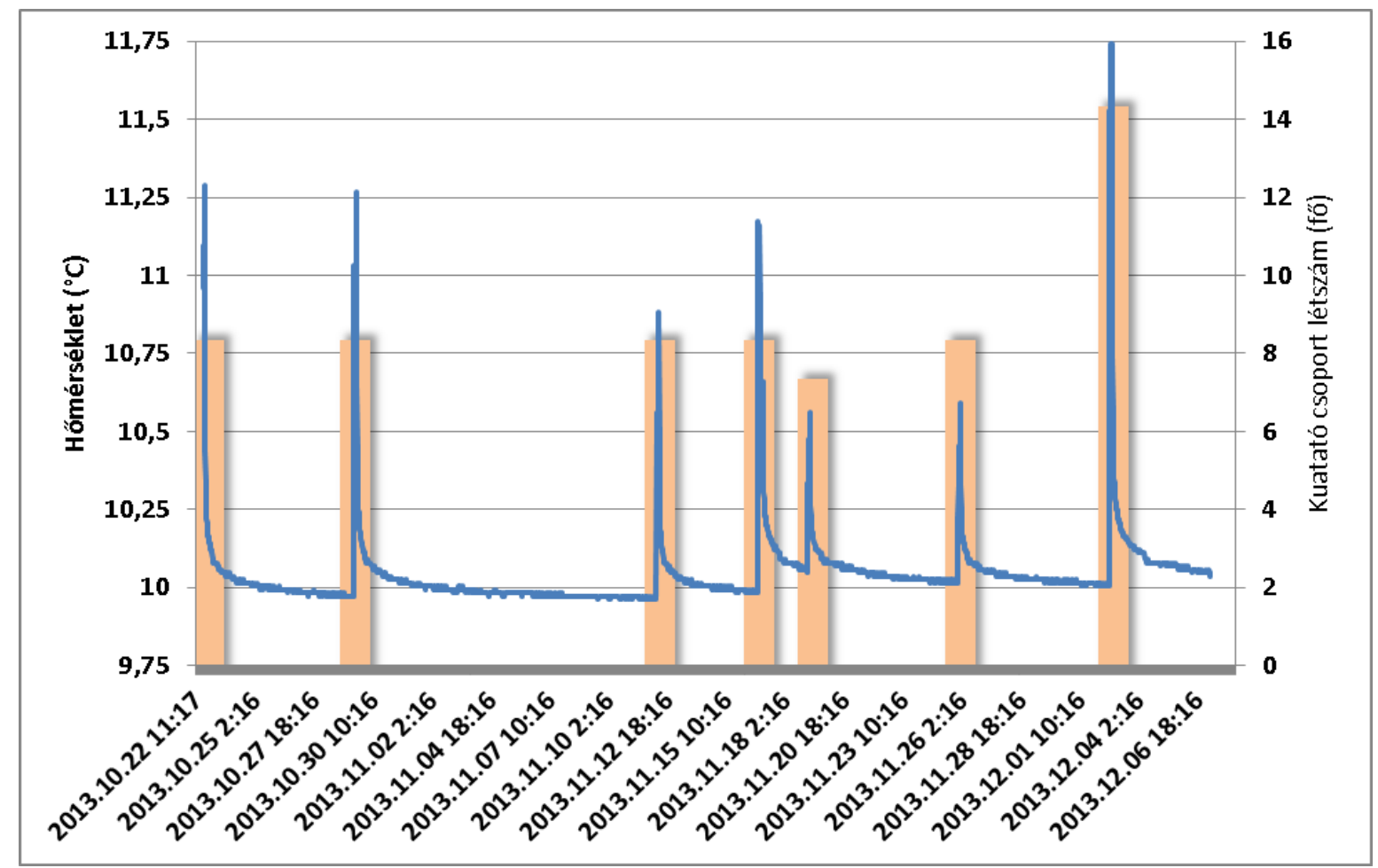

57. ábra A Pecsétnyomóban történt hőmérséklet-változások a bontások ideje alatt, 2013.10.2212.03. között

\section{Diszkusszió}

\subsection{Hajnóczy-barlang járatainak jellemzése}

A Hajnóczy-barlang egy felszín közeli barlang, hiszen az Óriás-terem és a Bejárat közeli szakaszok felett található a legkevesebb felszíntakaró $(2-10 \mathrm{~m})$. A fedőréteg mégis pufferként hat, hiszen a repedéseken keresztül nem érzéklehető a felszíni direkt módosító hatása (58. ábra). Az Óriás-terem $10,8{ }^{\circ} \mathrm{C}$-os átlagos hőmérséklete (26. ábra) télen a felszínt felmelegíti, mint ahogy az a hőkamerával készült képeken is látható (14. ábra). A nyári felmelegedés sem érzékelhető valamely repedésen keresztül, csak az átmelegedett fedőréteg hőátadása révén.

A járatok hőmérsékleti adatain (26. ábra) is látszódik, hogy a felszíni hőmérsékletváltozás módosító hatása miként érvényesül az egyes barlangszakaszokon. A vizsgálati időben a felszínen a napi átlag hőmérséklet $-6-29^{\circ} \mathrm{C}$ között változik. 


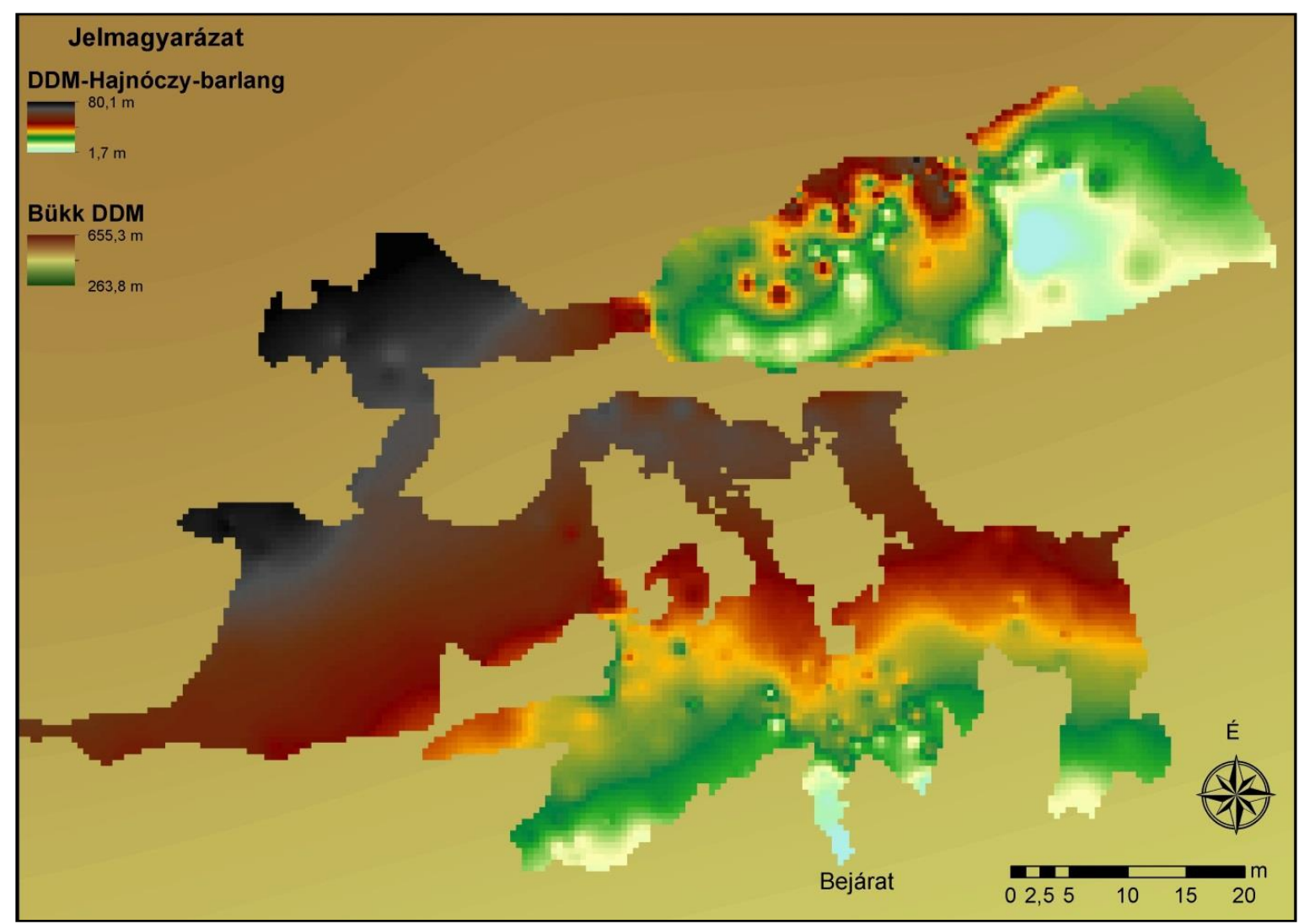

58. ábra A Hajnóczy-barlangot fedő kőzet és talaj vastagsága a járatok és termek fölött

A barlang légkörzését módosító hatásokat $(\Delta \mathrm{T})$ figyelembe véve három szakaszra oszthatjuk a barlangot:

- Az első szakasz a bejárati zóna, ahol az éves $\Delta \mathrm{T} 3,3-9,7^{\circ} \mathrm{C}$ között mozgott itt a hülési szakaszról beszélhetünk (26. ábra).

Ehhez a szakaszhoz a bejárat és az azt követő 14 m-es szakaszon található Bejárat, Háztető vizsgálati pontjai tartoznak.

Itt az átlagos hőmérséklet $5,7-7,5^{\circ} \mathrm{C}$ között változik, a vizsgálati pontok tengerszint feletti magassága 457-454 m,

- A második az örvénylési szakasz ahol a felszíni napi hőingás, illetve az évszakok változása is megjelenik, az éves $\Delta \mathrm{T}$ értéke $1-0,8^{\circ} \mathrm{C}$.

Ezek a vizsgálati pontok a szükebb keresztmetszetűek, a Lapos-terem, Nagyterem és Leyla között, Leyla, Mandula. Ez a bejárattól számított 14-64 m közötti szakasz. Az átlagos hőmérséklet 8,0-8,7 C között változik, a járatok magassága 439-430 m között található.

- A melegedési szakasz a $\Delta \mathrm{T} 0,3-0,1^{\circ} \mathrm{C}$ közötti változással. 
A bejárattól 64-73 m-re található Galéria, Galéria és Óriás-terem között, Óriásterem tartozik ide.

Az átlagos hőmérséklet $9,7-10,8^{\circ} \mathrm{C}$, a járatok magassága $453-476 \mathrm{~m}$.

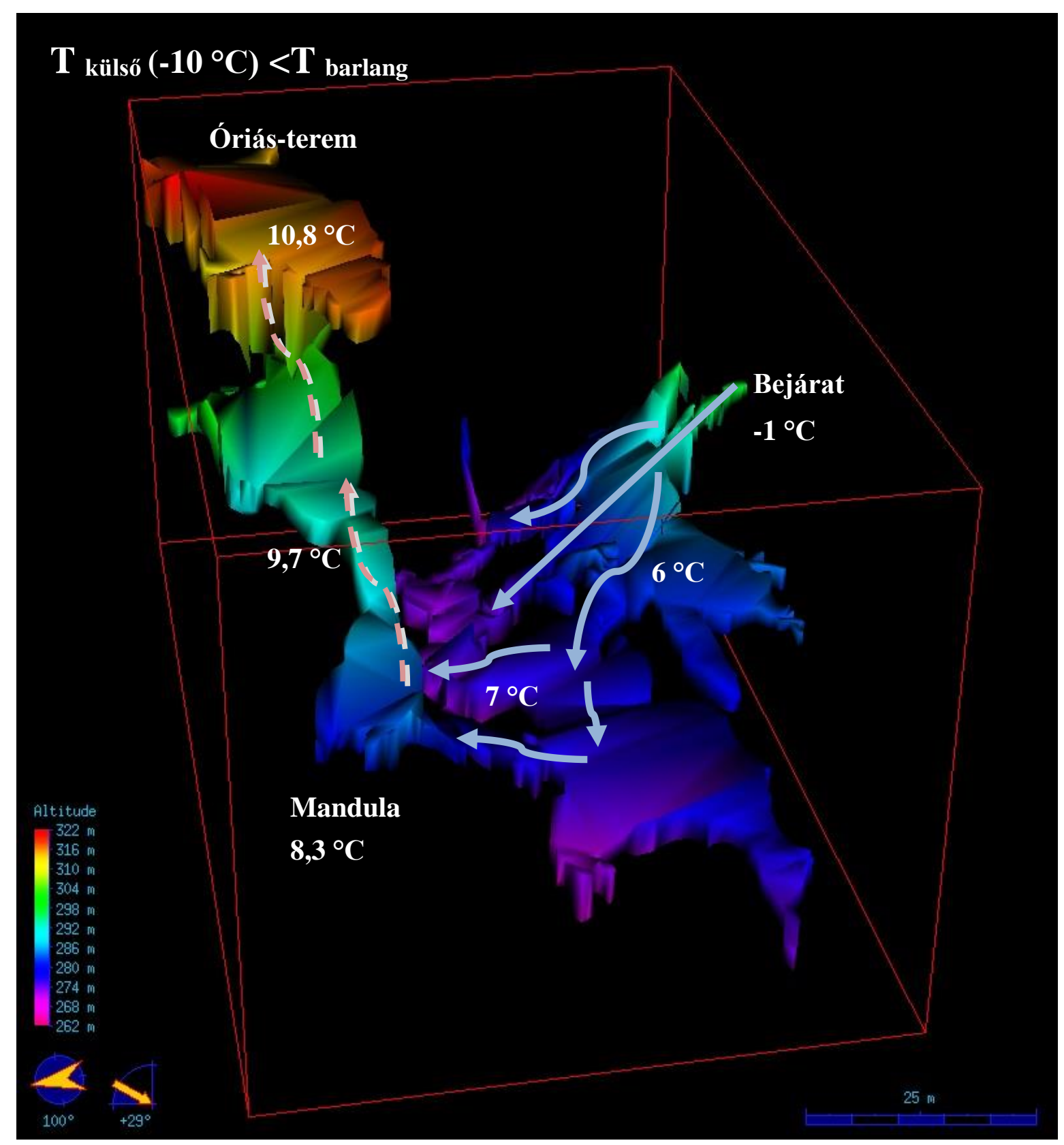

59. ábra A Hajnóczy-barlang légkörzése modellje a téli hónapokban

A Hajnóczy-barlang évszakos vizsgálata alapján elmondható, hogy a téli-nyári légkörzés fordulását a tartósan $10^{\circ} \mathrm{C}$ alatti napi hőmérséklet idézi elő. A vizsgált időszakban ez 2012.11.27-i időponttól kezdődik. A felszíni tartós lehülés egyre erőteljesebben hat a barlangi levegőre a Bejáraton keresztül a Mandula vonaláig (59. ábra) 
(Muladi, Mucsi, 2014). A Mandulától felfelé haladva az Óriás-teremig a levegő rétegzettsége alapján egy gyenge feláramló hatás a jellemző.

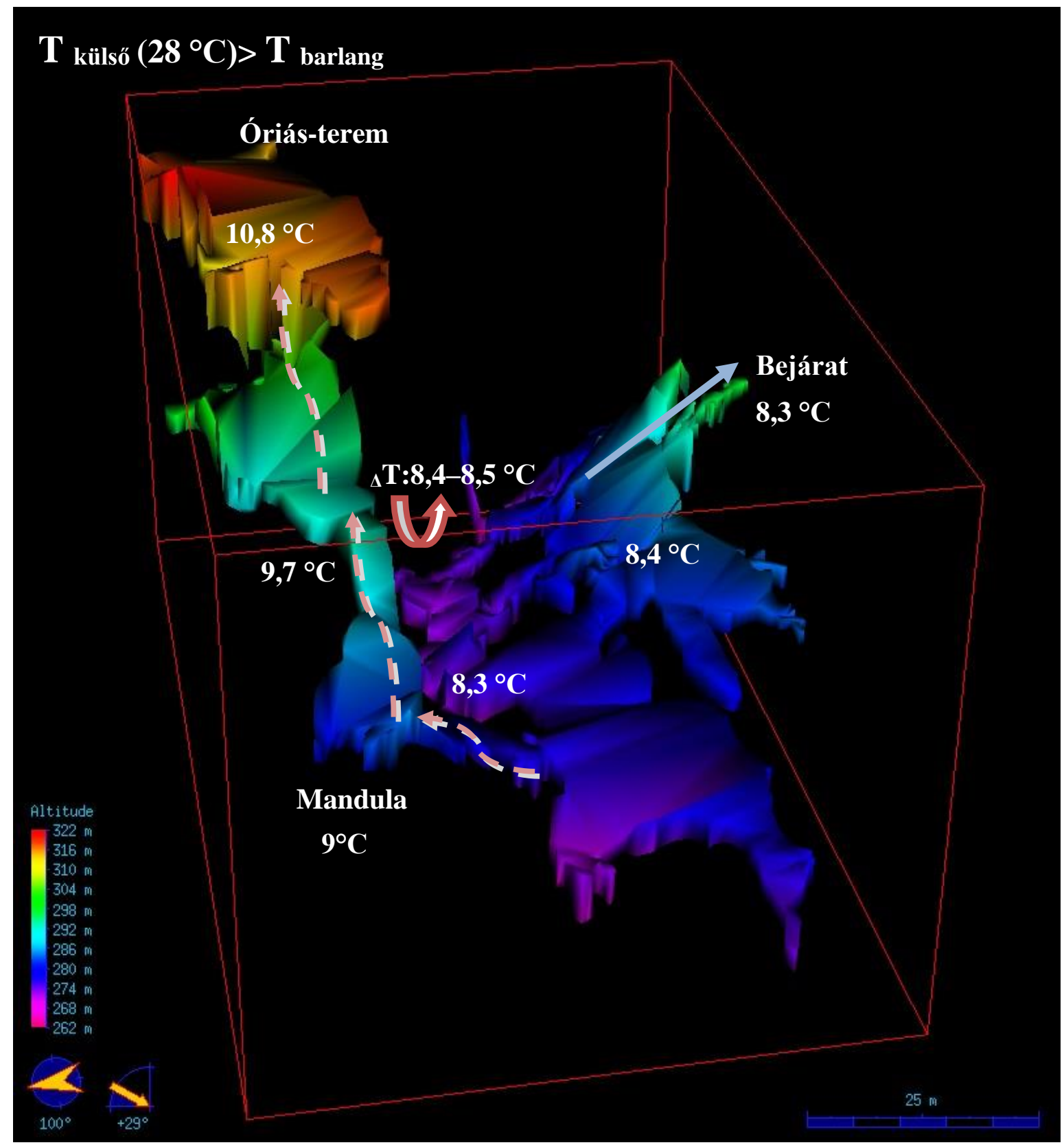

60. ábra A Hajnóczy-barlang légkörzés modellje a nyári hónapokban

A nyári hónapokban a Bejáratnál $10,9^{\circ} \mathrm{C}$-ra áll be a hőmérséklet, a felszíni meleg nem hat ezen a szakaszon. Az Óriás-terem esetében a vertikális rétegzettség hatására megmarad a gyenge feláramló légmozgás (60. ábra), de a felszíni napsugárázás hatása csak talaj hőátadásával történik meg, a vizsgált szakaszokon nagyobb repedések hatása nem befolyásolja a hőmérsékletet (42. ábra). Ugyanakkor a felmerül a kérdés, hogy a nyári 
hónapokban honnan pótlódik a Hajnóczy-barlang levegője? Erre a 2012-es nyári mérés során kaptam választ a kibővített vizsgálati helyszínek segítségével. A Lapos-terem keleti végében volt érezhető a napi hőingás (50. ábra) a D1-es pont irányából. Itt feltételezhető egy olyan repedés, mely felszínnel kapcsolatban áll (60. ábra).

Több elmélet is született annak kapcsán, hogy a Galériánál talált medvecsontok hogyan kerülhettek a barlang azon szakaszára. Egyes feltételezések szerint a magasabb helyzetü, felszín közeli járatokból mosódott be az állat, amelyek egykor valószínűleg a felszínnel voltak kapcsolatban (Kordos, 1984). A Hajnóczy József Barlangkutató Csoport is kísérletet tett az egykori barlang bejáratának felkutatására. Az 1983-as kutatatsi jelentésükben leírják, hogy az Óriás-terem egy felsőbb szakaszán próbálkoztak, melynek kapcsán feltárátk a Szabó András-termet (Mucsi, 1984). A megváltozott klíma miatt azonban a további kutatást felfüggesztették az Óriás-teremben és Galériában kialakult nagy méretű cseppkőképződmények megóvása érdekében. A Galéria és az Óriás-terem jelenlegi állapotát tekintve a mérések során nem érzékeltem olyan repedést, mely a barlangon belüli felszíni kapcsolatot mutatná (Muladi \& Mucsi , 2014).

A Hajnóczy-barlangban, a 2012-es nyári kutatótábor ideje alatt végeztem el az aperiodikus hatású vizsgálatokat a barlangban túrázó csoportok által okozott hőmérséklet változásról. A bejárati szakaszon 6 fös csoportok esetén $0,1-0,3{ }^{\circ} \mathrm{C}$ között változik a hőmérséklet (12. táblázat). Az örvénylési szakaszon 4-6 fö esetén $0,1-0,5^{\circ} \mathrm{C}$ között változik csoportok nagyságától függően, a járatok szük keresztmetszete segítette a levegő gyorsabb helyre állását (12. táblázat). A Leylánál és Mandulánál is 40 perc alatt lecsengett (50. ábra-51. ábra) a csoportok által okozott hőmérsékletnövekedés. A barlangi szakasz már a nagy termeket foglalja magában, azonban a Galéria szakaszán is érzékelhető a csoport okozta hőmérséklet-emelkedés $0,1-0,3{ }^{\circ} \mathrm{C}$ között változik (12. táblázat). Bár az Óriásteremben csak minimálisan látszódik, de a 12 fős csoport felborítja az egyensúlyi állapotot (53. ábra).

\subsection{A Hideg-lyuk járatainak jellemzése}

Az éves hőmérséklet-változások alapján elmondható, hogy a Hideg-lyukban vizsgált pontok közül:

- A bejárati zónában éves szinten $\Delta \mathrm{T}$ étéke $13,6-4,4{ }^{\circ} \mathrm{C}$ között változik 
Ebbe a zónába tartoznak Bejárat utáni és a Bányatámok adatai, a bejárattól 19 mig,

Az átlag hőmérséklet ezen a szakaszon $7,9-6,8^{\circ} \mathrm{C}$, magassága $197-187 \mathrm{~m}$.

- Az örvénylési szakasz esetében a $\Delta \mathrm{T}=2,7-1,6^{\circ} \mathrm{C}$.

A Rézágyú-terem, a Referencia-bivak, Medvecsapda, Guillotine, vonala a bejárattól 32-48 m-re található.

Itt az átlaghőmérséklet $7,9-8,5^{\circ} \mathrm{C}, 190-183$ m-es tengerszint feletti magasságon,

- A barlangi szakaszon a $\Delta \mathrm{T}=0,5-0,9^{\circ} \mathrm{C}$.

A bejárattól 55-88 m-re található járatok a Lépőcsavarok, a Pecsétnyomó, és a Karácsony-terem tartoznak ide. Ezen a szakaszon adathiány volt ugyan, de minden időszakból rendelkezem minimálisan szükséges adattal, így elmondható, hogy itt már barlangi légkörzés található, ahol, a járatok átlagos hőmérséklete 9,7$10,7^{\circ} \mathrm{C}, 190-186$ m-es tengerszint feletti magassággal.

A Referencia-bivak és környéke lehet a barlang hideg pontja a vizsgált szakaszon, mivel ez már az örvénylési szakaszon belül helyezkedik el, a vertikális magasság alapján nem ez helyezkedik el a legmélyebben, viszont ezen a szakaszon itt volt a legalacsonyabb az átlagos hőmérséklet. A Referencia-bivak kiemelkedik a környező mért pontok közül, mivel a hőmérséklet-változás a Rézágyú-terem, Medvecsapda és Guillotine körül 2,4$2,7^{\circ} \mathrm{C}$, addig a Rézágyú-teremben csak $1,9^{\circ} \mathrm{C}$.

A Gábor Áron-aknában a nyári hőmérséklet-változás alapján az alábbi csoportokat különítettem el:

- A bejárati zóna, ahol a $\Delta \mathrm{T}>4,1{ }^{\circ} \mathrm{C}$ ez az akna bejárattól $20 \mathrm{~m}$-es szakaszig érzékelhető itt az átlagos hőmérséklet $17,7-8,2{ }^{\circ} \mathrm{C}$.

- Örvénylési zóna ebben az esetben nincs

- A barlangi szakasz $\Delta \mathrm{T}<0,3{ }^{\circ} \mathrm{C}$ az akna alján ahol a barlangi hőmérséklet érvényesül, ebben a vizsgálati pontban az átlaghőmérséklet $7,7^{\circ} \mathrm{C}$, a tengerszint feletti magassága $188 \mathrm{~m}$.

A Rézágyú-teremben elmondható, nyári légkörzés esetén a Gábor Áron akna nincs hatással erre a szakaszra, a középső két szenzor esetében minimális örvénylés alakul ki a különböző járatok hatására. 


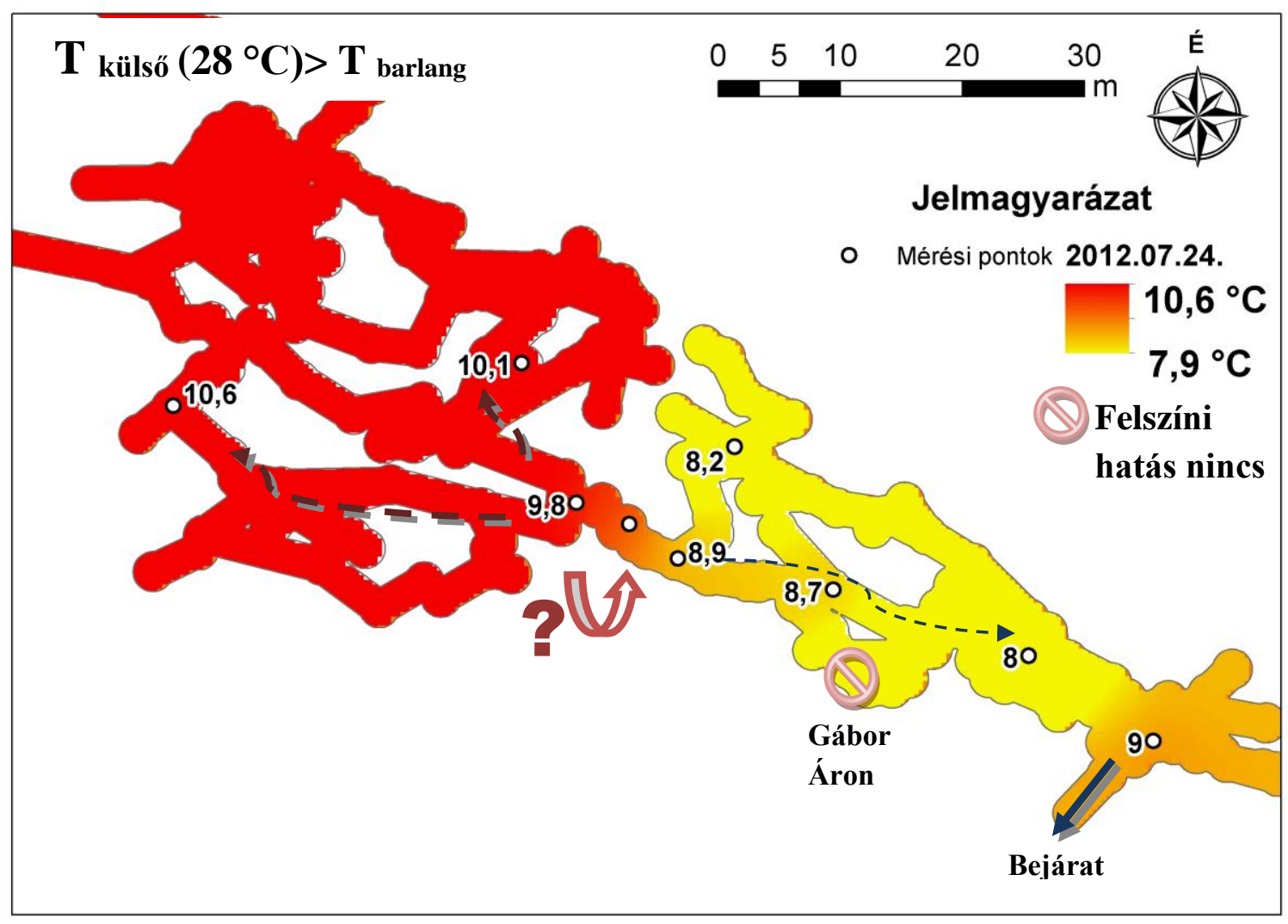

61. ábra A Hideg-lyuk hőmérsékletének térbeli eloszlása és légáramlása a nyári hónapokban

A nyári légkörzés idején az Alsó-bejáraton intenzíven kiáramló $9{ }^{\circ} \mathrm{C}$-os levegő figyelhető meg. A Bejáratéhoz hasonló simított görbe jellemzi a Bányatámok, Rézágyúterem, és a Referencia-bivak környékét, tehát ezen a szakaszon a barlangi hideg levegő hat. A nyári hónapokban a Gábor Áron aknában megül a hideg levegő, így érdemben nem vesz részt a légkörzésben (61. ábra). A Medvecsapda és a Guillotine egy omladékosabb szakasza a barlangnak, itt a nyári napi ingás megjelenik. De honnan származik ez a hatás? A tektonikailag preformált területen elöfordulhatnak olyan szakaszok, melyek a repedezettségük következtében jól kommunikálnak a felszínnel. Ennek a szakasznak a különlegessége, hogy a téli időszakban nem jelenik meg a hideg levegő a repedéseken, csak a bejáraton át tóduló hideg levegő fejti ki módosító hatását (62. ábra). A Szabó József Barlangkutató Szakosztály kutatóinak feltételezése szerint egy alsó eddig fel nem tárt barlangi járat az, mely a Hideg-lyuk légkörzését módosítja. A Medvecsapda és a Guillotine közötti szakaszon már a hőmérséklet vizsgálatok megkezdése előtt egy 3m-es kutató aknát ástak, ennek felderítésére, de nem jártak sikerrel. A mérések adatfeldolgozása után viszont még pontosabb képet kaptunk erről a szakaszról, és láthatóvá vált, hogy mégis érdemes lenne folytatni a kutatást. A várt remények ugyan elmaradtak, hiszen az alsó barlangot nem 
találtuk meg, de a méréseim eredményei alapján kitüzött bontási pontból egy 25 m-es új szakaszt találtunk a kutató akna alján, mely vízszintesen halad tovább.

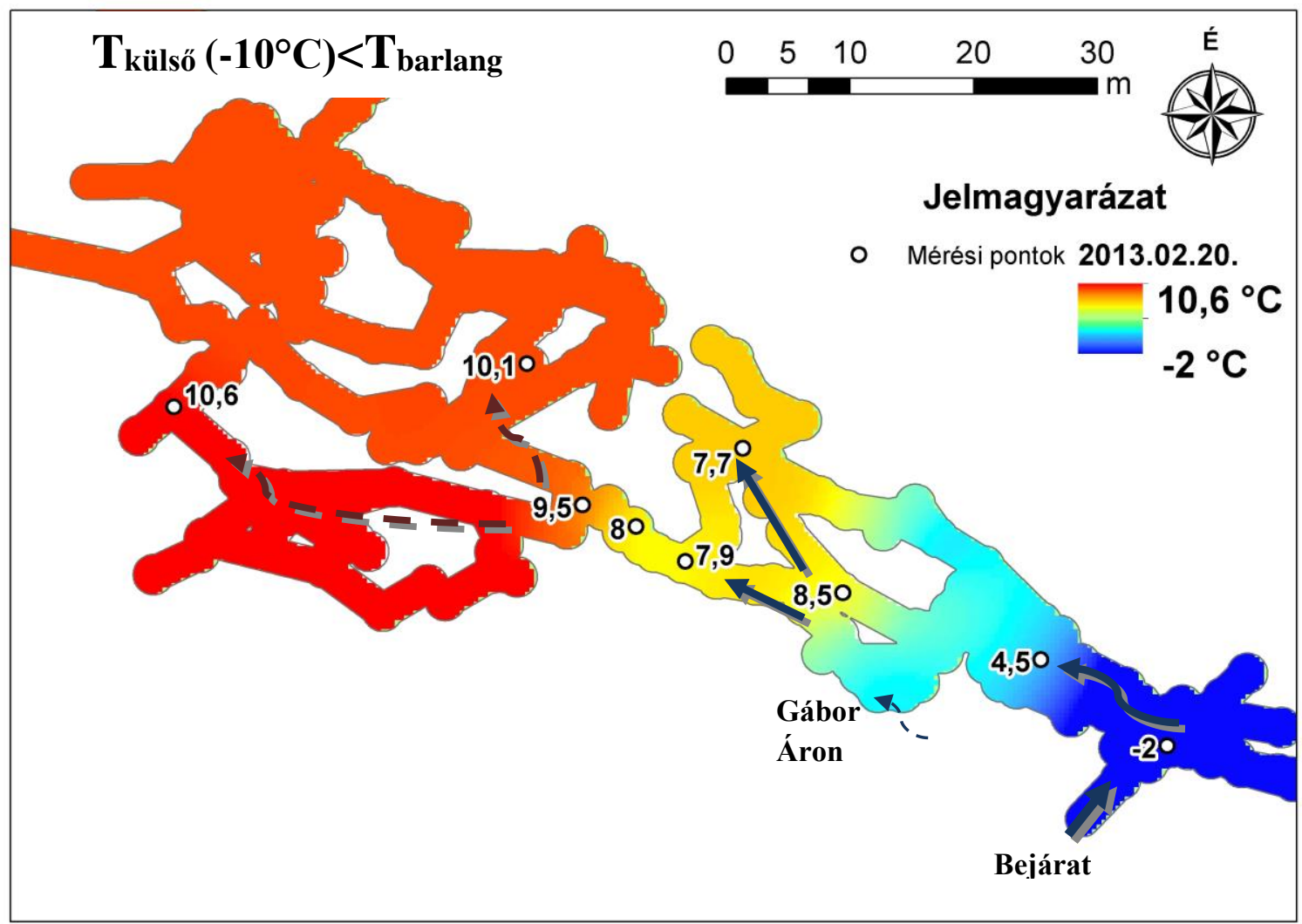

62. ábra A Hideg-lyuk hőmérsékletének eloszlása és légkörzése a téli hónapokban

A Pecsétnyomóban végzett aperiodikus vizsgálat során képet kaphattam arról, hogy egy adott helyen intenzív fizikai munkát végző kutatócsoport közel $2{ }^{\circ} \mathrm{C}$-kal is módosíthatja környezetét, sőt ugyan ez az érték sokkal magasabb is lehetett volna, ha közelebb helyezkedik el a szenzor a bontási ponthoz (57. ábra).

\subsection{Pál-völgyi-barlang járatainak jellemzése}

Az igazán barlangi szakaszt, ahol egész évben nem változik a hőmérséklet, és a felszíni hatások már nem érvényesülnek, ebben a vizsgálatban nem tudtam meghatározni. A Pál-völgyi- barlang tektonikailag erösen feldarabolt, így a repedéseken átszivárgó felszíni levegő, még kifejti módosító hatását. A vizsgálatot a későbbiekben még nagyobb mintaterületre lenne érdemes kiterjeszteni. 
Az eddigi adatok alapján elkészítettem a vizsgált időszakra a barlang járatainak hőmérséklet-változás szerinti csoportosítását (63. ábra). Négy csoportot különítettem el ahol az egyes járatokat a hőmérséklet-változás értékei alapján csoportosítottam:

1. Felszíni hatás eröteljes $\Delta \mathrm{T}>2,5^{\circ} \mathrm{C}$,

2. Gyenge felszíni hatás $1{ }^{\circ} \mathrm{C}<\Delta \mathrm{T}<2,5^{\circ} \mathrm{C}$,

3. Átmeneti szakasz $0,5^{\circ} \mathrm{C}<\Delta \mathrm{T}<1{ }^{\circ} \mathrm{C}$,

4. Barlangi szakasz $\Delta \mathrm{T}<0,5^{\circ} \mathrm{C}$.

A felszíni hatás erőteljesen befolyásolja a turisztika számára kiépített barlangszakaszt. Ugyan itt antropogén vizsgálatra nem került sor, mert a müszerek elzárása nem volt lehetséges a látogatók elől a barlang károsítása és a szenzor hő puffer nélkül, de ezen a szakaszon a járatok jó kommunikációja a felszínnel, valamint tektonikailag preformált hasadékrendszere biztosítja a megfelelő szellőzöttséget.

Az alaprajzi térkép alapján, a bejárattól számított távolságot figyelembe véve elmondható, hogy:

- É-D irányban:

- a felszíni hatás erőteljes a bejárattól számított 65-67 m-ig (Vészkijárat-Színházteremig, illetve a Hódjáratig) (63. ábra 9,10),

- a gyenge felszíni hatás érvényesül a bejárattól számított 67-107 m térbeli távolság között (Huzatos-folyosó - Pentacon-terem környéke) (63. ábra 15-19),

- átmeneti szakasz található a bejárattól számított 107-147 m között a Bekey-terem tetejéig, valamint a Technikás-ágig (63. ábra 22,23),

- barlangi szakasz húzódik a bejárattól a vizsgálati végpontig 147-215 m között, Bekey-terem Gyöngyös-folyosó és Z-folyosó Y-terem irányába pontok között (63. ábra 24-27),

- az egyensúlyi szakasz 215 m-nél távolabbra található a barlangban, de így is lehetnek lokális helyek (pl.:Huzatos-folyosó), ahol a repedések mentén érvényesül a felszíni hőingás.

- K-Ny irányba:

- a felszíni hatás a Kijárat, Bejárat és a Köhíd között dinamikusan változik, ennek térbeli távolsága 84 m (63. ábra 1-7),

- a gyenge felszíni hatás 73-75 méteres térbeli távolságra terjed ki (Meseország, Púderkürtő, Dombos folyosó) (63. ábra 8,21,11),

- az átmeneti szakasz 95 m az Oroszlán sarok és a Dombos-folyosó végéig (63. ábra 20,10), 


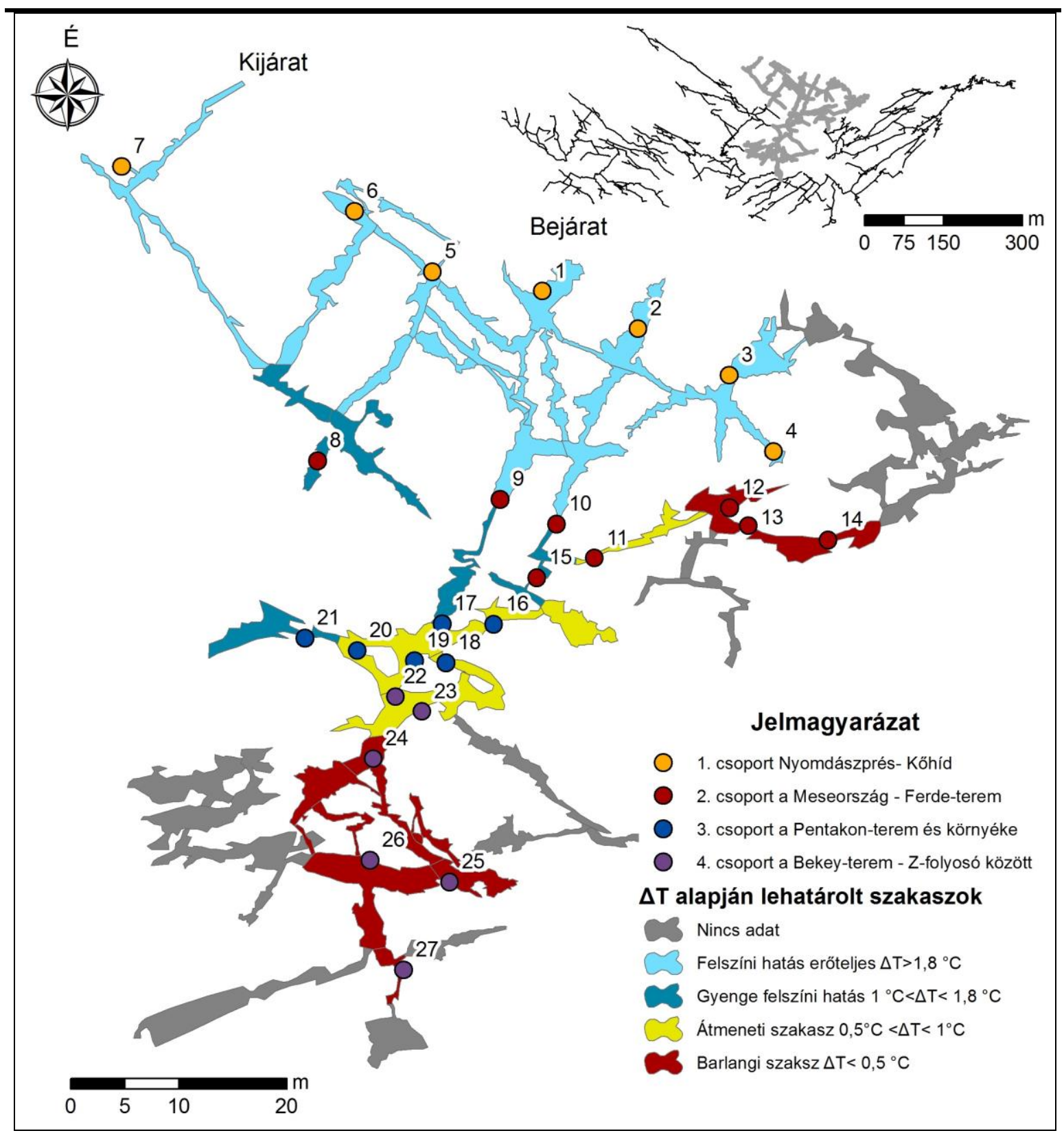

Szenzorok helye

\begin{tabular}{llllll}
\hline 1 & Bejárat után & 10 & Hódjárat & 19 & Pentacon-terem Bekey-felé \\
\hline 2 & Keresztezés & 11 & Dombos-folyosó & 20 & Oroszlán sarok \\
\hline 3 & Köhíd korlát mögött & 12 & Palánkai-terem & 21 & Púder kürtö \\
\hline 4 & Köhíd & 13 & Palánkai- és Ferde-terem között & 22 & Bekey-terem teteje \\
\hline 5 & Tyúklétra után & 14 & Ferde-terem & 23 & Technikás-ág-Ablak \\
\hline 6 & Scholz próba csövön & 15 & Huzatos-folyosó & 24 & Bekey-terem Gyöngyös-f. \\
\hline 7 & Nyomdászprés bejárata & 16 & Pentacon-terem Nagyfal alja & 25 & Hajós-terem kötélen \\
\hline 8 & Meseország mögött & 17 & Pentacon-t Vészkijárat, Elöszoba & 26 & Tollas-terem Gyöngyös-t. \\
\hline 9 & Vészkijárat- Színház-terem & 18 & Pentacon-terem Technikás-ág eleje & 27 & Z-folyosó kezdete Y-terem \\
\hline
\end{tabular}

63. ábra A Pál-völgyi-barlang vizsgált pontjai átlaghőmérséklet alapján, valamint a járatok a

hőmérséklet-változás alapján történt csoportosítása (vizsgálati időszak: 2013.04.24-2014.04.27.) 
- a barlangi szakasz ebben az irányban kettéválik ezen a mintaterületen, a Palánkaiterem és Ferde-terem között 45 m térbeli távolságra (63. ábra 12-14), valamit a Hajós-terem és Tollas-terem között (19 m) (63. ábra 25-26).
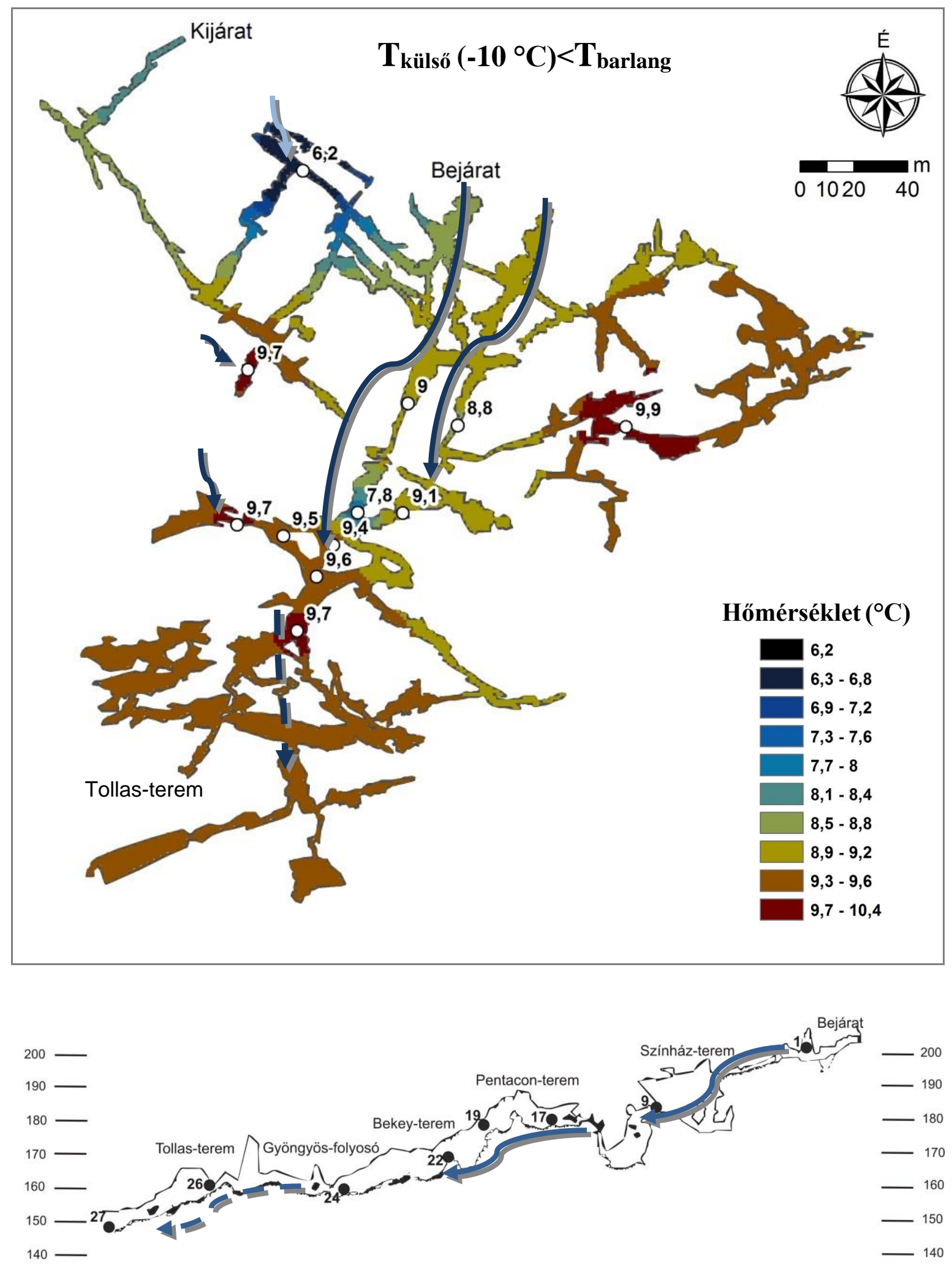

64. ábra A Pál-völgyi-barlang légkörzése téli hónapokban (hőmérséklet adatok 2014.01.12. állapotot mutatják) 

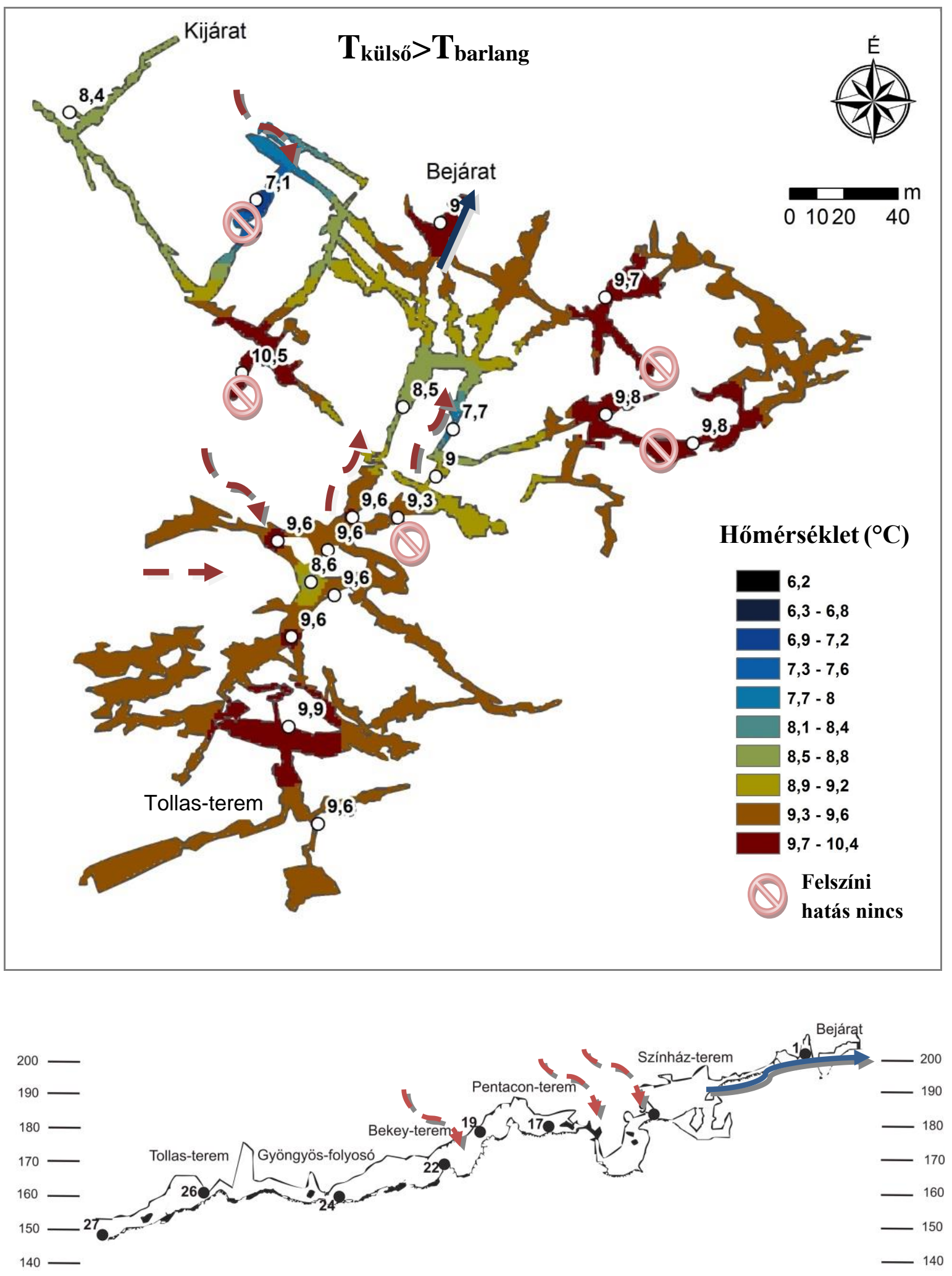

65. ábra A Pál-völgyi-barlang légkörzése nyári hónapokban (hőmérséklet adatok 2013.07.03-i állapotot mutatják) 
A Pál-völgyi-barlang esetében a téli légkörzésének bemutatása alapján szintén elmondható, hogy a hideg levegő a bejáraton keresztül végig folyik egészen a Tollasteremig (64. ábra). A Tyúklétránál. Meseországnál, és a Púder-kürtőben hat még intenzíven a hideg felszíni levegő. A Bekey-teremtől a Tollas-teremig, már csak enyhén érezhető a hideg légtömeg. A nyári légkörzés esetén, a bejáraton kiáramlik a levegö, csak a Púderkürtő- és Tyúklétra esetében érezhető a felszíni nyári meleg hatása és ez módosítja a Színház-terem, Hódjárat, Huzatos-folyosó szakaszait is. A Meseország, Scholz próba, Kőhíd-terem, Ferde-terem, Pentacon Nagyfal nem vesz részt a légkörzésben (65. ábra).

\subsection{Harcsa-barlang járatainak jellemzése}

A Harcsaszájú-barlangban a 2013.04.28.-2013.06.10. között az átlaghömérséklet és a hőmérséklet-változás alapján az alábbi szakaszokat különítettem el:

- Bejárati szakasz jellegü az összes Előcsarnokból nyíló járat (a Harcsaszáj alatti bontás-Bejárat után) itt $0,7^{\circ} \mathrm{C}<\Delta \mathrm{T}<2,1^{\circ} \mathrm{C}$ (37. ábra 2-8).

Ezen a szakaszon belül még három csoportot tudtam elkülöníteni:

- A Bagyura-barlang felé, a Bagyura-barlang fölötti járat, Bejárat után a hőingás $1,8{ }^{\circ} \mathrm{C}<{ }_{\Delta} \mathrm{T}<2,1^{\circ} \mathrm{C}$ között változik (37. ábra 4, 6, 8).

- A Harcsaszáj alatti bontás, Bagyura-barlang alatti járat $\Delta \mathrm{T}=1,3{ }^{\circ} \mathrm{C}$, bár az átlaghőmérsékletek között mutatkozik különbség $\left(1,5^{\circ} \mathrm{C}\right)$, mivel a két járat vertikálisan 18,8 m távolságra helyezkedik el egymástól. A Harcsaszáj alatti bontás $8,5^{\circ} \mathrm{C}$, míg a Bagyura-barlang alatti járat $7{ }^{\circ} \mathrm{C}$ hőmérsékletü (37. ábra 2,7).

- A kevésbé jól szellőző pontok a Bagyura-barlang felé bontás és a Bejárat fölött itt a hőmérséklet-változás értéke $0,7{ }^{\circ} \mathrm{C}<\Delta \mathrm{T}<0,8^{\circ} \mathrm{C}$ között változik (37. ábra $3,5)$.

- Az örvénylési szakasz a Bejárati akna közepétől az Omladék Guillotine előtti pontig érzékelhető (37. ábra 9-14). Ennek a szakasznak a tengerszint feletti magassága 191186 m. Ezen a szakaszon az átlaghőmérséklet 9,6-7,2 ${ }^{\circ} \mathrm{C}$ között változik, a hőingás $0,6^{\circ} \mathrm{C}<\Delta \mathrm{T}<0,9^{\circ} \mathrm{C}$.

- A barlangi szakasz az Guillotine kötélen szakasztól érzékelhető egészen az utolsó vizsgálati pontig a Tej bontásig (37. ábra 15-18). A barlangi szakaszon belül is két csoportot tudtam elkülöníteni: 
- Az egyik szakasz a Guillotine-akna vertikális vizsgálata a 16 Belyukadásig, a tengerszint feletti magasság $184-176 \mathrm{~m}$, ahol az átlaghőmérséklet $8,6-9^{\circ} \mathrm{C}$ között alakul, a hőmérséklet-változás $0,2-0,4{ }^{\circ} \mathrm{C}$ (37. ábra 15$)$.

- A 16 Belyukadás esetében $\Delta \mathrm{T}=0,7^{\circ} \mathrm{C}$, ami a felszíni maximum értékek módosító hatása miatt érzékelhető. A Pannonia-folyosón is párhuzamosan érzéklehetők ezek a maximum értékek, viszont a Belyukadás esetében felerősödnek. Ez a keresztmetszet szükülésének is köszönhető, illetve a repedés hálózat is segítheti ezt a folyamatot (37. ábra 16).

- Az Új rész és a Tej hasadék bontása a vizsgált szakasz legmélyebb része 177$164 \mathrm{~m}$. Az átlaghőmérséklete már $1{ }^{\circ} \mathrm{C}$-kal magasabb, mint az előző szakaszé, $10,2-10,9^{\circ} \mathrm{C}$, a $\Delta \mathrm{T}=0,2^{\circ} \mathrm{C}(37$. ábra $17-18)$.

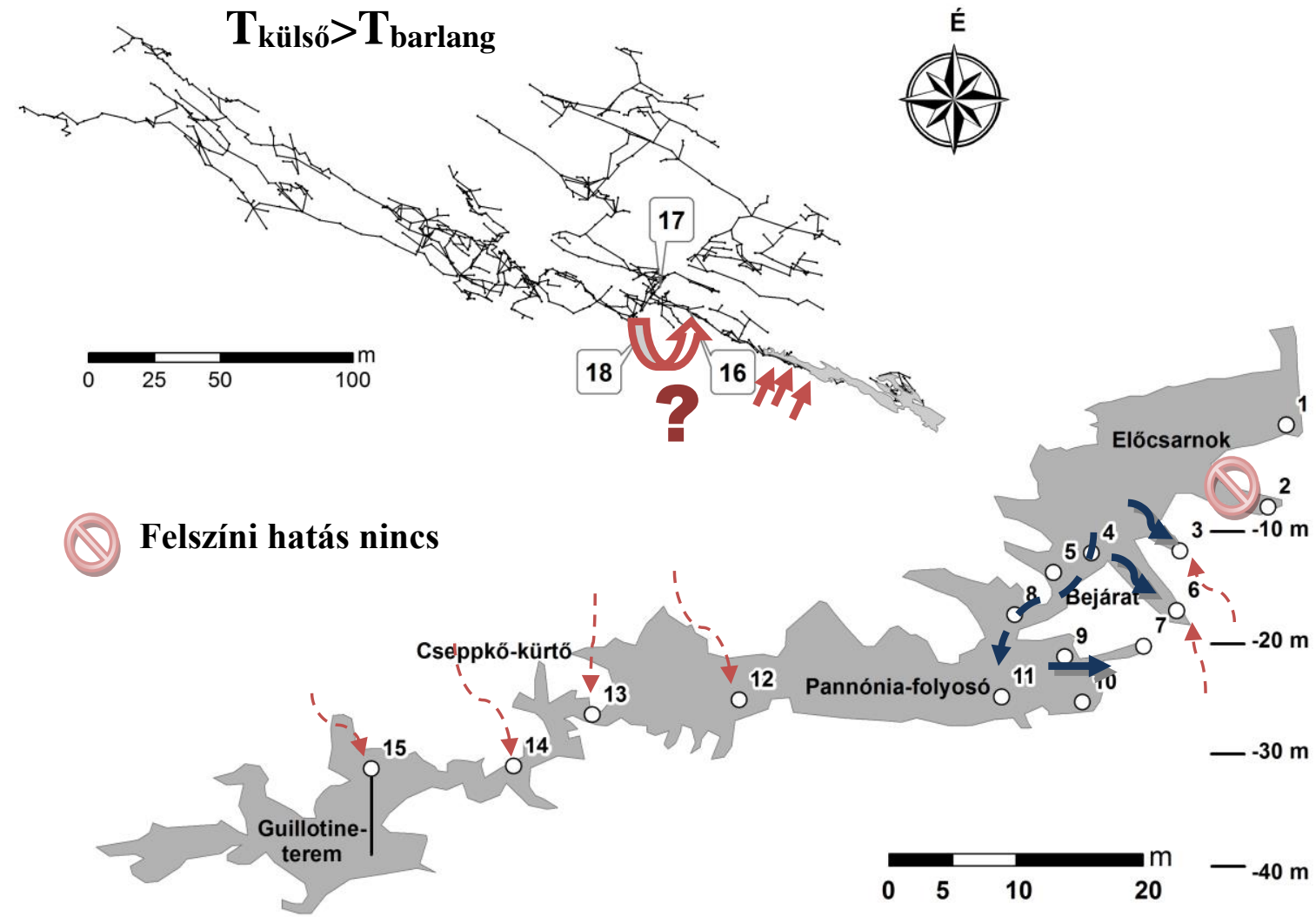

66. ábra A Harcsaszájú-barlang légkörzése nyári hónapokban

A Harcsaszájú-barlang nyári légkörzése esetén az Előcsarnokból induló járatokban az éjszakai lehűlések hatására a hideg levegő „lefolyik”, ugyanakkor a Bagyura-barlang hatására a nappali felmelegedés is láthatóvá válik (Bagyura alatt, Bagyura fölött) (66. ábra). A Harcsaszáj alatti bontásnál nem érzékelhető huzat, a Pannónia folyosó kezdeténél pedig csak a felszíni lehülés mutatkozik meg. 


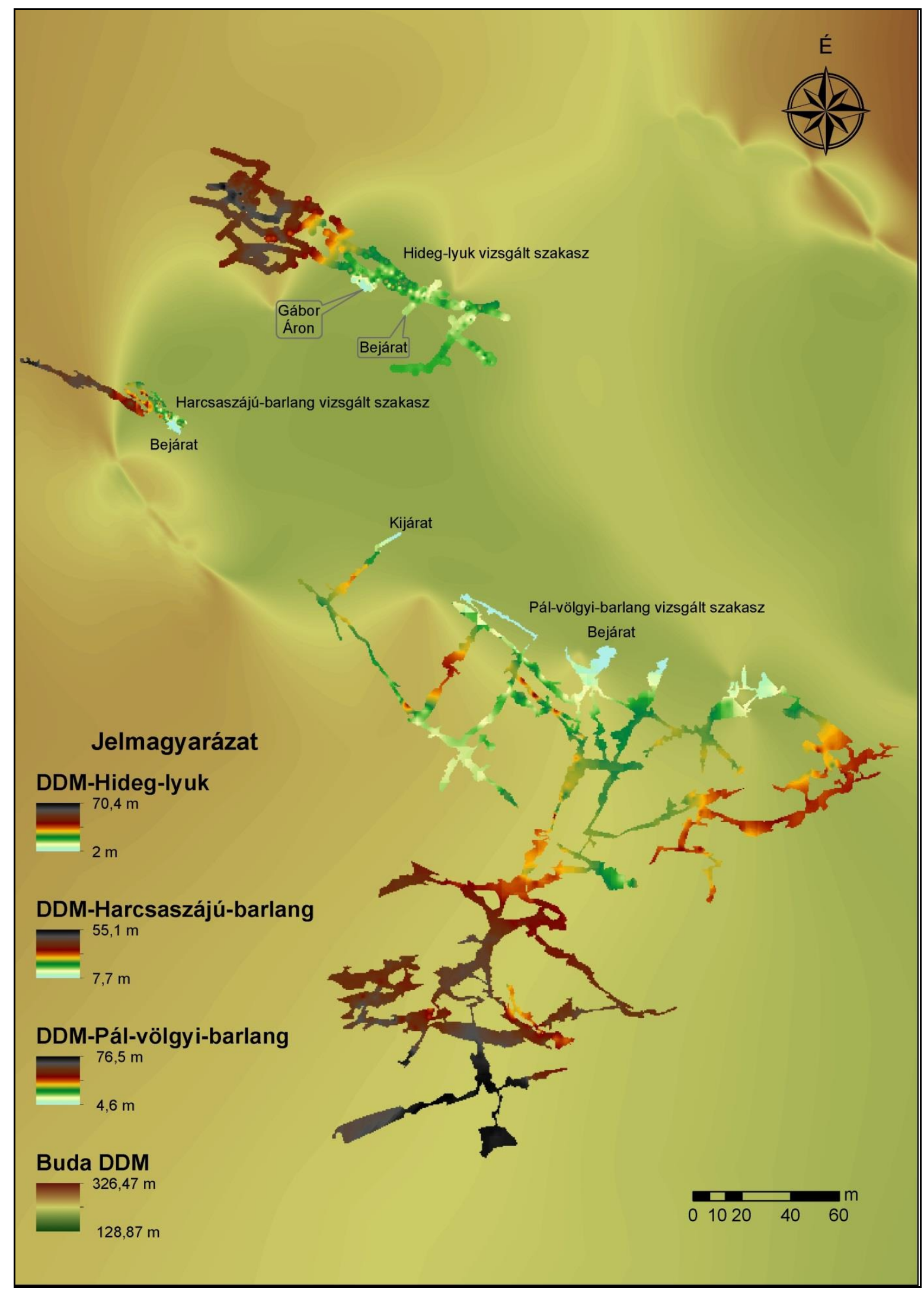

67. ábra A Pál-völgyi-barlangrendszer vizsgálati szakaszai és az azok fölötti talaj- és kőzet réteg vastagsága 
A Lépőcsavaroktól a Guillotine-tetejéig, mely egy nagyobb omlásban található, a napi maximumok hatása jelentkezik (Guillotine alján nem!), illetve a Belyukadásnál is megfigyelhető ez a hatás, ami már 5 m-rel mélyebben helyezkedik el.

A Szép-völgyi-barlangrendszer tagjainak (Pál-völgyi-barlang, Hideg-lyuk és Harcsaszájú-barlang) vizsgálata alapján elmondható, hogy a kőzet erősen töredezett, így a barlangok belsőbb szakaszaiban is érezhető a felszín hőmérséklet-módosító szerepe. A járatot fedő réteg vastagsága 2-76 m között változik (67. ábra). Az örvénylési szakaszoknál $1015 \mathrm{~m}$ fedőréteg lehet a járatok fölött, mégis a legtöbb esetben a bejáraton keresztül kommunikál a felszínnel a barlangi levegő. A Pál-völgyi-barlang esetében a Púder-kürtő az, melyen keresztül cserélődik a barlangi levegő, ugyanakkor a Hideg-lyuknál a Gábor Áron-akna nem vesz részt a nyári légkörzésben. A Hideg-lyuk és a Harcsaszájú-barlang esetében a nyári légkörzés esetén olyan helyen lépnek fel a meleg levegő általi módosító hatások ( a Nagy sziklatömbös omlások mentén), ahol már közel $50 \mathrm{~m}$ fedőréteg van. A repedéseken keresztül hathat a feszíni meleg, vagy egy második összekötő járat lehet a két barlang között? A terület hidrotermális eredetét tekintve nem kizárt, hogy egy mélyebb hasadék is közrejátszik a légáramlás kialakulásában (68. ábra). A terület pontosabb geológiai feltérképezése is szükséges ennek a kimutatására, illetve további hőmérsékletmérésekre is szükség lenne, föként azért mert a két barlang között elhelyezkedő Pál-völgyi sziklaüreg azon a területen található, ahol keresztirányú hasadék lehet.

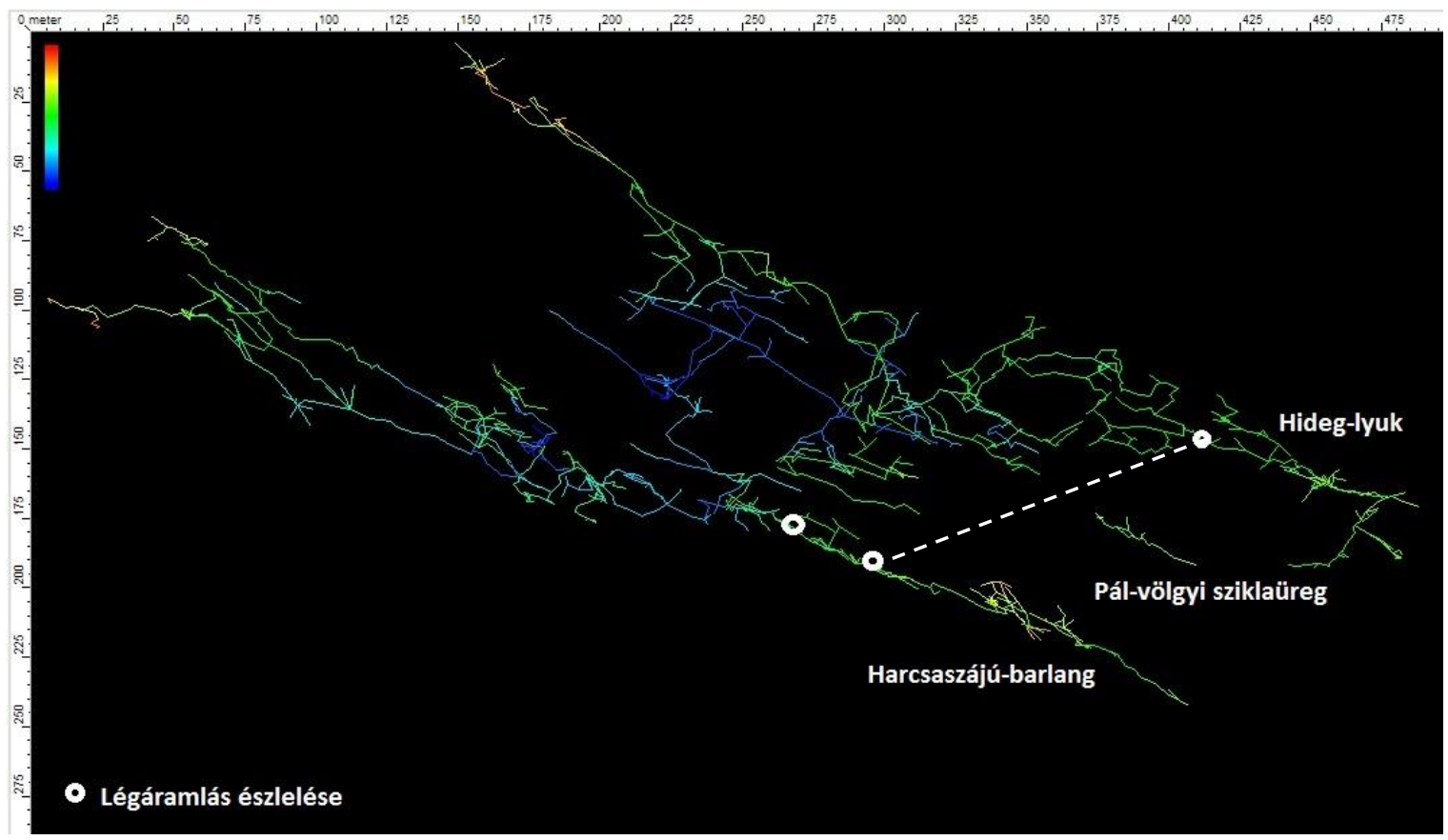

68. ábra A Harcsaszájú-barlang, Hideg-lyuk légáramlás észlelése, és a Pál-völgyi sziklaüreg elhelyezkedése 


\subsection{Trió-barlang járatainak jellemzése}

A Trió-barlang járatainak vertikális hőmérséklet rétegzettsége alapján elmondható (69. ábra), hogy a zsákszerü barlangok, egyik típuspéldája (Muladi , et al., 2012). A nyári idősoron látható, hogy az éjszakai lehülések a Búboskemencéig hatnak a barlangban, ezzel is megakadályozván, hogy a végponti melegebb levegő feláramoljon (69. ábra). A Búboskemencéig lehatoló hidegebb levegő, az akna soron már kevésbé hat.

A legalsóbb járatok fölött már 80-90 m-es szelvénytömb helyezkedik el (70. ábra), tehát ezek már csak a bejáraton keresztül tudnak kommunikálni a felszínnel.

Az időszakos mérés esetében nehezebb a zónákat elkülöníteni a hőmérséklet ingása alapján, hiszen az évszakos változások nem jelennek meg. A mérés sorozatot az nehezítette még, hogy a mérés ideje alatt leesett nagy mennyiségü eső a barlangban is megjelent, és a szenzorok víz alá kerültek.

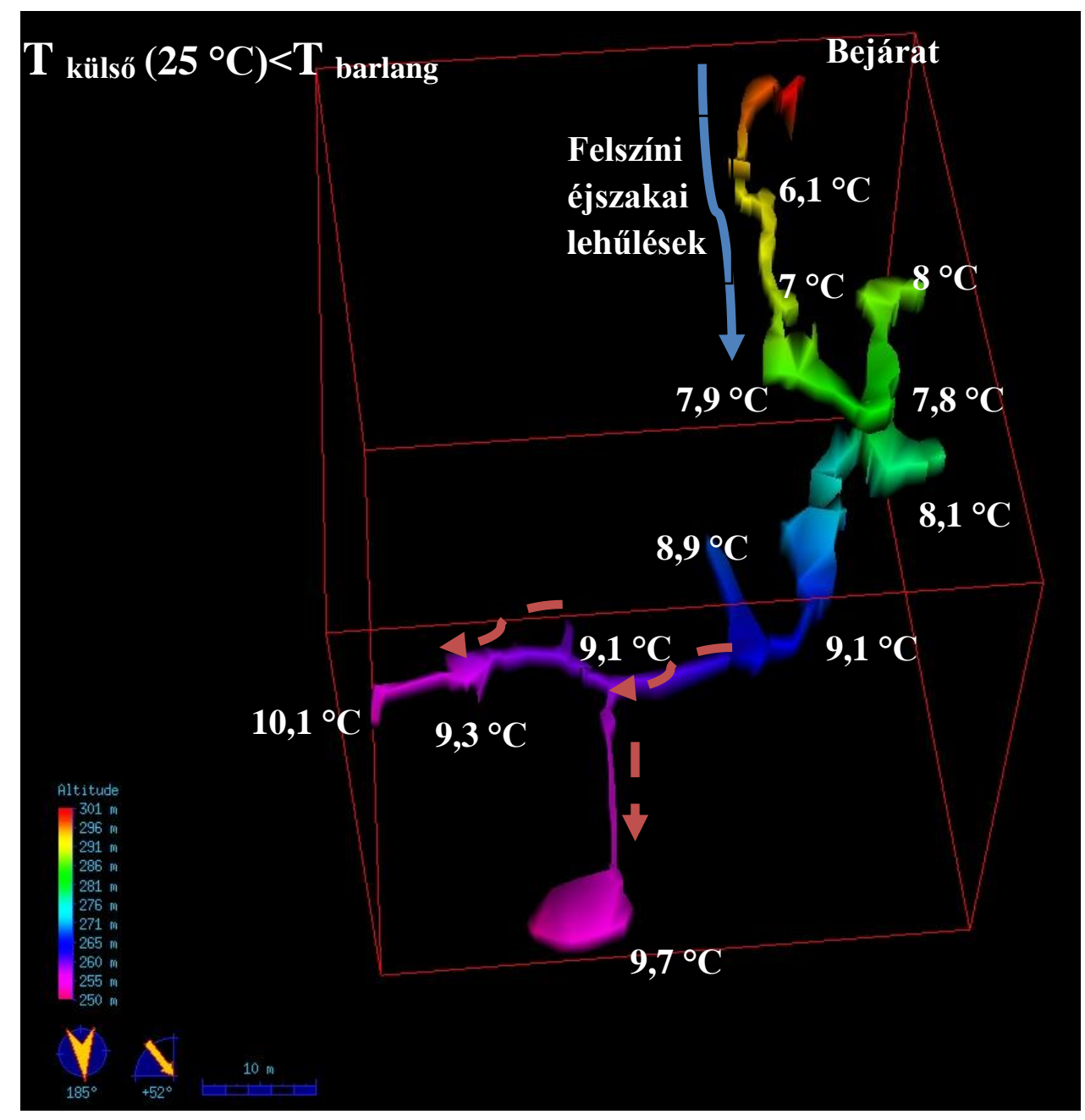

69. ábra A Trió-barlang légkörzése nyári hónapokban 
A tavaszi hőmérsékletvizsgálat alapján az alábbi következtetéseket vontam le:

- A bejárati zóna részei a Gerinctörő, itt még megjelenik a felszíni hatás, ${ }_{\Delta} \mathrm{T}>$ $1,3{ }^{\circ} \mathrm{C}$, ez a szakasza $6 \mathrm{~m}$ térbeli távolságra található a bejárattól, a Könyvtár esetében kevés információnk van a hőmérséklet-változásról, az átlagos hőmérséklet értéke alapján soroltam ebbe a csoportba 6,6-7 ${ }^{\circ} \mathrm{C}$ (69. ábra).

- Az átmeneti szakasz a Búbos kemencétől a Brassói ágig tart. Mivel a téli hónapokból nincsenek információim, és a jelenlegi mérés hiányos, így a $\Delta \mathrm{T}$ értéke is erre a tavaszi légkörzés idejére értendő, amikor $0,3{ }^{\circ} \mathrm{C}<_{\Delta} \mathrm{T}<0,6{ }^{\circ} \mathrm{C}$. Az átlagos hőmérséklet alapján $7,8-8,1{ }^{\circ} \mathrm{C}$ között változik, ez a szakasz a bejárattól 24-34 mes távolságra található (69. ábra).

- A barlangi szakasz a 3-as akna utáni járattól a két végpontig tart. $\mathrm{A} \Delta \mathrm{T}<0,3^{\circ} \mathrm{C}$, az átlagos hőmérséklet $9-10^{\circ} \mathrm{C}$ között alakul, a bejárattól számított távolság alapján a 3-as akna 47 m-re, míg az Örszem-teremi végpont 78 m-re, az Agyagos-ági kút pedig 83 m-re található (69. ábra).

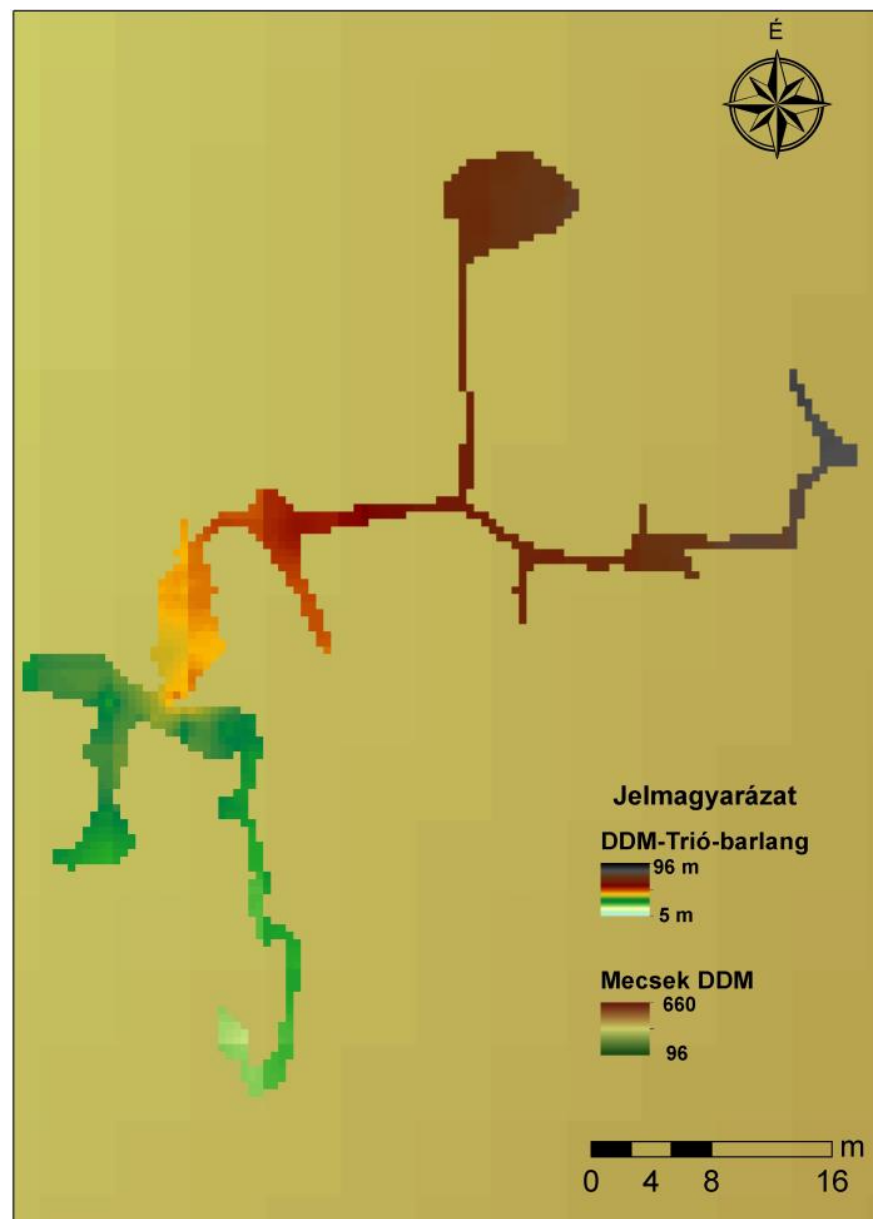

70. ábra A Trió-barlangot fedő kőzet és talaj vastagsága 


\section{Összefoglalás}

Doktori kutatásom során, három karsztterületen különböző morfológiai adottságokkal rendelkező barlangban vizsgáltam a barlangklíma sajátosságait.

Munkám során a barlangklíma vizsgálatához új módszert fejlesztettem ki az UC Mote Mini vezeték nélküli szenzorhálózat eszközével. A barlangi hőmérsékletméréssorozatom megkezdése előtt már megbizonyosodtam arról laboratóriumi, és barlangi körülmények között, a müszerek alkalmasak lesznek a vizsgálathoz. A szenzorok $0,01{ }^{\circ} \mathrm{C}$ os felbontása lehetővé tette, mind a természetes, mind pedig az antropogén eredetü legapróbb hőmérséklet-változások kimutatását. A müszerek pontosságának $0,3{ }^{\circ} \mathrm{C}$-os különbségét a mérések megkezdése elött kalibrációval küszöböltem ki. A müszerek könnyen és gyorsan telepíthetők, szállításuk a barlangban megoldható. A szenzoroknak nem okozott problémát a magas páratartalom, ugyan előfordultak adathiányok és extrém körülmények, amikor a járatok víz alá kerültek, de ezek nem károsították a müszereket. A vezeték nélküli szenzorhálózat új típusú eszközével sikeresen megvalósítottam az adatgyüjtést a barlangokban.

Barlangi mérések megkezdése előtt 2011 decemberében a bükki Hajnóczybarlangban teszteltem (10 percenkénti adatokkal rendelkezem a barlangról). 2012-től folyamatosan bővült a vizsgálati helyszínek sora, a budai barlangokban 2012 áprilisától a Hideg-lyuk barlangban, 2013 áprilisától a Pál-völgyi barlangban mértem, majd időszakos vizsgálatok történtek a Harcsaszájú-barlangban is, (Pál-völgyi-barlangrendszer tagjai). A Mecsek-hegységben a Szuadó-völgy víznyelöjében, a Trió-barlangban is végeztem időszakos vizsgálatokat. A Hideg-lyuk és Hajnóczy-barlangban 10 db müszer kihelyezésre került sor, ahonnan 10 percenkénti adatrögzítéssel az előbbinél $61.934 \mathrm{db}$, az utóbbinál $94.533 \mathrm{db}$ adatot használtam fel a különböző járatokról feldolgozott elemzésemhez. A Pálvölgyi-barlangban $27 \mathrm{db}$ müszert helyeztünk el, mely segítségével $32.216 \mathrm{db}$ adattal rendelkeztem a barlangturisták által elzárt területekröl. A Harcsaszájú-barlang és Trióbarlang esetében 4000 adatot dolgoztam fel.

Elkészítettem a járatok hőmérséklet eloszlásának vertikális metszetét, a vizsgálati idő alatt mért átlaghőmérsékletek alapján. Az adatok alapján bebizonyosodott, hogy a bejárati szakaszok esetében még érvényesül a vertikális különbségek okozta hőmérséklet rétegződés. Például a Hideg-lyuk 25 m mély Gábor Áron aknabejáratánál érvényesül a hőmérséklet ezen rétegződése, az akna bejárat és talppontja között $10{ }^{\circ} \mathrm{C}$-os különbséggel. A barlangon belül függetlenül a tengerszint feletti magasságtól egyre melegedő tendencia 
figyelhető meg. A járatok átlaghőmérséklet adatai alapján bebizonyítottam, hogy a bejárattól vett távolság nagyobb mértékben befolyásolja a hőmérséklet eloszlását, mint a tengerszint feletti magasság.

Lehatároltam a járatokban bekövetkező napi, évszakos és éves hőingás és a barlangok bejáratától számított távolságuk alapján a bejárati, az örvénylési és a barlangi légkörzés szakaszát. A vizsgált barlangok esetében a konvekciós légáramlás hatására télen hủlési, nyáron pedig a barlangból kiáramló levegő jelentkezik. Minden barlangban egyedi módon alakul a felszíni hatás, amely járatokban más-más intenzitással érvényesül. A vizsgált barlangok között volt olyan, melyekben egy évnél hosszabb távú hőmérsékletváltozás alapján csoportosítottam a járatszakaszokat, de volt olyan is, amelyet évszakos megfigyelés alapján kategorizáltam. Barlangonként más térbeli intervallumot kellett megadnom, hiszen a bejáratuk, a felszínnel kapcsolatot biztosító repedéshálózat, járatmorfológia eltérő hatást idézett elő.

Két barlangban hosszabb idejü vizsgálatokat végeztem. A Hajnóczy-barlang esetében a bejárati szakasz $14 \mathrm{~m}$-ig tart $\left(\Delta \mathrm{T}=3,3-9,7^{\circ} \mathrm{C}\right)$, az örvénylési szakasz a $14-64 \mathrm{~m}$ közötti szakasz $\left(\Delta \mathrm{T}=0,8-1{ }^{\circ} \mathrm{C}\right)$, a barlangi szakasz ezen belül helyezkedik el $\left(\Delta \mathrm{T}=0,1-0,3{ }^{\circ} \mathrm{C}\right)$. $\mathrm{A}$ Hideg-lyuk barlangban 19 m-ig figyelhető meg a bejárati szakasz $\left(\Delta \mathrm{T}=4,4-13,6{ }^{\circ} \mathrm{C}\right)$, az örvénylési szakasz $48 \mathrm{~m}$-ig jellemző $\left(\Delta \mathrm{T}=1,9-2,7^{\circ} \mathrm{C}\right)$, ezután a barlangi szakasz $(\Delta \mathrm{T}=0,5-$ $0,9^{\circ} \mathrm{C}$ ) található. Meghatároztam, nyári légkörzés idején, a barlang bejáratok teljes keresztmetszetében a szabadba áramló levegő maximális hőfokát, mely barlangonként eltérő hőmérsékletet mutat (a Hajnóczy-barlangból kiáramló levegő $8,3{ }^{\circ} \mathrm{C}$-os, míg a Hideg-lyukból kiáramló 9,4 ${ }^{\circ} \mathrm{C}$-os). A Pál-völgyi-barlang és Harcsaszájú-barlang esetében a bejárati zónában még részletesebb csoportosítást végeztem aszerint, hogy a felszíni hatás erőteljesebben vagy gyengébben hat.

Kimutattam az évszakos és a napi hőingások mértékét a barlangok különböző szakaszain. Az évszakos hőingás vizsgálata során kimutattam, mikor történik a huzat fordulása. Az évszakok közül a tavaszi és az őszi légkörzés egy rövidebb átmeneti állapot, amikor minimális a hőingás a barlangok minden szakaszán. A napi hőingás értékeket elemezve megállapítottam, hogy milyen légköri, hatások okozzák a barlangban fellépő hőmérséklet-változását. Lokalizálni tudtam olyan pontokat a barlangban, ahol nem a bejáraton keresztül történik a légkörzés. A járatok fölött elhelyezkedő talaj- és mészkő vastagságát megvizsgálva meghatároztam azt, hogy az adott hasadék vagy repedés permeábilis-e. Ezen pontok vagy járatszakaszok beazonosítása a feltáró barlangkutatás számára nagy jelentőséggel bír. A mérések segítségével a Hideg-lyukban egy 
járatszakaszon légmozgást figyeltem meg és egy régebben felhagyott bontási ponton a kutatók 2014 nyarán egy 20 m hosszúságú járatot tártak fel.

Meghatároztam az antropogén hatás mértékét a csoportlétszám és járatok méretének függvényében. Az eddigi antropogén hatás vizsgálatok főként tömegturizmus számára kiépített barlangokban történtek a szakirodalmak szerint. A Hajnóczy-barlang változatos keresztmetszetü járataiban a nyári kutatótábor alkalmával naponta barlangba induló kutatók segítségével, a hömérséklet adatok alapján, nyomon követhetö a volt barlangban megtett útjuk. Ezek alapján meg tudtam határozni a különböző járatszelvényekben jelentkező hőtöbblet nagyságát is, melyet a különböző csoportok okoztak. A vizsgálataim során választ kaptam arra, hogy nem csak a szükjáratokban érzékelhető a csoportok okozta pozitív hőmérsékleti anomália, de a nagyobb terekben is. Az okozott hőmérsékletemelkedés mellett a lecsengési időket is fel tudtam mérni a járatkeresztmetszetek függvényében. Lehetőségem nyílt egy overálos barlangtúráztatásra hasznosított barlangban, (a Trió-barlangban) a különböző csoport létszám okozta hőtöbblet meghatározására.

A vizsgált barlangok járatait ért hatások alapján elkészítettem minden barlangra egyegy komplex légáramlásmodellt. Az egyes járatok évszakos átlaghőmérséklete, valamint a hőingások alapján kimutatható vált, hogy egyes esetekben a bejáraton beáramló levegő évszaktól függően meddig módosítja a barlang klímáját, vagy lokálisan hol alakulnak ki olyan anomáliák a hőmérsékletben, amelyek sajátos légáramlást okoznak. A nyári légkörzések esetén kimutathatóvá vált, hogy a barlangbejáratán át kiáramlik a levegö, de a vizsgálataimmal az is kiderül, az egyes barlangok esetében mely szakaszon áramlik be a levegő (Hajnóczy-barlangban a Lapos-teremben, a Hideg-lyukban a Medvecsapda és Guillotine szakszán). Ezeket a hatásokat ábrázoltam balrangok 3D-s modelljén, vagy hőtérképén. 


\section{Summary}

My doctoral research addressed the investigation of microclimate features in caves of different morphology situated on three karst areas.

A new method was developed to investigate cave climate using UC Mote Mini wireless sensor network. Before the continuous temperature measurements in caves the applicability of the devices was proved in both laboratory and cave environments. The $0.01{ }^{\circ} \mathrm{C}$ scale of the sensors allowed the detection of slight temperature changes of natural and anthropogenic origin. The $0.3{ }^{\circ} \mathrm{C}$ difference in accuracy was eliminated by calibration of the devices before the measurements. The devices can be easily and rapidly installed and transported in the caves. High humidity was not problematic for the sensors. Extreme underwater conditions in the caves resulted in data gaps, however, these events did not cause damages in the devices. Using the new type of wireless sensor network I successfully performed continuous data collection in caves.

In the initial phase of the research the devices were tested in laboratory environment, and the tests demonstrated that with adequate calibration the $0.3{ }^{\circ} \mathrm{C}$ deviation between the devices can be eliminated. Preliminary measurements were carried out in a climate chamber to provide exact calibration constants for each sensor. Before the continuous measurements in the caves the sensors were tested in the Hajnóczy Cave in the Bükk Mountains in December 2011 (the parameters were measured in a 10-minute interval). During the research the number of study areas was continuously increasing. From April 2012 and April 2013 there were continuous measurements in the Hideg-lyuk Cave and in the Pál-völgyi Cave (in Buda Hills), respectively, and there were temporary measurements in the Harcsaszájú Cave (being the member of the Pál-völgyi cave system) and in the Trió Cave (in Western Mecsek karst area, Szuadó valley). 10 devices were placed in both the Hideg-lyuk and the Hajnóczy Caves, where data were recorded in a 10 minute-interval, thus altogether 61.934 and 94.533 data from the two caves were used for the assessment, respectively. 27 devices recorded 32.216 data from the Pál-völgyi Cave providing information on caves closed from tourists. In case of the Harcsaszájú and Trió Caves, 4.000 data were analysed.

Based on the measured mean temperature the vertical cross section of temperature distribution in the cave passages was performed. The measured data confirmed that at the cave entrance sections temperature layering can be observed due to the vertical differences. 
For example $10{ }^{\circ} \mathrm{C}$ temperature difference was detected between the pit entrance and the deepest explored point at the Áron Gábor $25 \mathrm{~m}$ long pit entrance in the case of the Hideglyuk Cave. Independently from height above sea level an increasing temperature can be observed from the entrance towards the interior of the cave. Using the measured mean temperature data of cave passages it was detected that the distance from the entrance has higher influence on the temperature distribution than the height above sea level.

Entrance, turbulence and cave air circulation sections were delimited using the daily, seasonal and annual fluctuation of the temperature and the distance from the entrance. Due to the convection air flow, cooling is observed in winter, while in summer the air flows out from the investigated caves. The impact of surface conditions on the caves are diverse, and the resulted changes in the cave passages have different intensity. The categorization of the cave sections was carried out based on long-term temperature measurements and seasonal observations. Different spatial intervals were given for each caves, as their entrances, the fracture system connecting the surface, and the passage morphology caused different impacts.

Long-term measurements were carried out in two caves. In the Hajnóczy Cave the entrance section is $14 \mathrm{~m}\left(\Delta \mathrm{T}=3.3-9.7^{\circ} \mathrm{C}\right)$, the turbulence section is between $14 \mathrm{~m}$ and $64 \mathrm{~m}\left(\Delta \mathrm{T}=0.8-1{ }^{\circ} \mathrm{C}\right)$, than it is followed by the cave section $\left(\Delta \mathrm{T}=0.1-0.3^{\circ} \mathrm{C}\right)$. In the Hideg-lyuk Cave the entrance section is $19 \mathrm{~m}\left(\Delta \mathrm{T}=4,4-13,6^{\circ} \mathrm{C}\right)$, the turbulence section is observed between $19 \mathrm{~m}$ and $48 \mathrm{~m}\left(\Delta \mathrm{T}=1,9-2,7^{\circ} \mathrm{C}\right)$, and it is followed by the cave section $\left(\Delta \mathrm{T}=0,5-0,9^{\circ} \mathrm{C}\right)$. The maximum temperature of the airflow from the cave was also determined during summer air circulation, which resulted in different values for the investigated caves $\left(8.3{ }^{\circ} \mathrm{C}\right.$ for the Hajnóczy Cave and $9.4{ }^{\circ} \mathrm{C}$ for the Hideg-lyuk Cave). In the Pál-völgyi and Harcsaszájú Caves the entrance zone was further classified according to the rate of surface influence.

The rate of seasonal and daily temperature fluctuations was determined in different cave sections. The seasonal temperature fluctuation assessments revealed the changes of the airflow direction. Spring and autumn air circulations were short transitional periods, when the temperature fluctuation is low in all section of the caves. The assessment of the daily temperature fluctuation revealed what are the atmospheric reasons for the temperature changes in the caves. I could allocate such points in the caves where the air circulation is not through the entrance. The thickness of soil and limestone layers above the passages was assessed to reveal if the given fissure or fracture is permeable or not. The allocation of these points or passage sections is of high importance for cave exploration. 
The cave measurements allowed the detection of an airflow in a section of the Hideg-lyuk Cave, where researchers explored a new $20 \mathrm{~m}$ long section of the cave in summer 2014 at a formerly researched point.

The rate of anthropogenic influence was determined based on group and passage sizes. The former measurements of anthropogenic influence were carried out mainly in show caves according to the literature. In the passages of the Hajnóczy Cave characterized by diverse cross sections, the daily visitor groups of a summer research camp were tracked by the measured temperature values. Based on these, the heat surplus caused by the visitors in the different passage sections were identified. My results highlighted that not only in narrow passages, but in wider halls the positive temperature anomaly due to the visiting groups can be detected. Beside the resulted temperature rise the relaxation time was also determined for all passages. The heat surplus due to different visitor group sizes was investigated in certain sections of the Trió Cave that is used only for overall cave visits.

Complex air convection models were set up for all investigated caves based on the impacts on the cave sections. The assessment of the seasonal mean temperature and its fluctuation in the different passage sections revealed that in what distance the inflowing air through the entrance can modify the cave climate seasonally or where local temperature anomalies can develop which cause specific air circulation. During summer air circulation it was shown that air was flowing out of the caves through the entrance, however, there were other cave sections where air inflow was detected (in the Lapos Hall of the Hajnóczy Cave and in the sections of Medvecsapda and Guillotine in the Hideg-lyuk Cave). These influences were indicated on the 3D models and the heat maps of the caves. 


\section{Köszönetnyilvánítás}

Mindenekelőtt szeretnék köszönetet mondani témavezetőmnek, Dr. Mucsi Lászlónak, aki nemcsak a doktori éveim alatt, hanem már hallgató koromtól kezdve is folyamatosan támogatott és irányt mutatott nekem.

A dolgozatom nem jöhetett volna létre Dr. Maróti Miklós segítsége nélkül, aki Szegedi Tudományegyetem TAMOP 4.2.2 "Szenzorhálózat alapú adatgyüjtés és információfeldolgozás"címü projektvezetőjeként az itt fejlesztett UC Mote Minikből $100 \mathrm{db}$-ot rendelkezésemre bocsájtott, valamint $1000 \mathrm{db}$ elemmel támogatta a méréseimet.

A projekt egyik programozója Bíró András, aki rengeteget segített a müszerek hibáinak kiküszöbölésén.

Csépe Zoltánnak köszönök mindent, néhány dolog ezek közül: a müszerek használatának betanítását, az adatok értelmezését, a statisztikai programok megismertetését, a műszerek barlangi kihelyezését, a támogatását, a cikkekben való közremüködését és folytathatnám a sort.

Dr. Barta Károlynak elsősorban köszönöm, hogy megismertette a barlangok világával, és Mecsekkel. Bármilyen szakmai kérdéssel fordulhattam hozzá, ő mindig készségesen segített, sőt a Hajnóczy-barlangban, valamint a Trió-barlangban is segítségemre volt a müszerek kihelyezésénél.

Dr. Pál-Molnár Elemérnek köszönöm a folytonos biztatását és szakmai tanácsait, hogy mihamarabb elkészüljön a dolgozatom.

A vizsgálataim során összesen 32 alkalommal történt barlangi leszállás:11 alkalommal szálltunk le a Hajnóczy-barlangba, a Hideg-lyukban 12-szer történt müszer csere, a Pálvölgyi-barlangban 5 alkalommal, a Harcsaszájú-barlangba, a Trió-barlangba pedig 2 terepi mérést végeztem.

A müszerek kihelyezésében, cseréjében 5 barlangkutató csoport segítette munkámat:

- Barit Barlangkutató Csoport kutatásvezetőjének Nagy Gergely Domonkosnak köszönöm, hogy megismertette velem a Harcsaszájú-barlangot.

- Bekey Imre Gábor Barlangkutató Csoport tagjai közül köszönöm Tóth Attila kutatásvezetőnek a támogatását, Kiss Attilának és Kunisch Gyöngyvérnek a fotókat, Laufer Csabának az állandó barlangi kíséretet, és rengeteg történetet a barlangokról, valamint Zentay Zoltánnak a barlangtúrákat.

- Hajnóczy József Barlangkutató Sportegyesület kutatásvezetőjének Varga Csabának köszönöm, hogy érdekes történetekkel mutatta be a barlangot, Mezó Ákosnak köszönöm a sok segítséget, és hogy mindig biztosított a Galéria felmászásánál.

- A Szabó József Barlangkutató Szakosztály kutatásvezetőjének Nagy Andrásnak köszönöm, hogy támogatta a méréseim. Állandó túravezetőm Polyák Ádámnak köszönöm, hogy mindig oda figyelt hová lépek, a jó hangulatú bontásokat a Hideg-lyukban, valamint különösen köszönöm, hogy a Gábor Áron akna még 
kiépítetlen állapotában kimászta, és rögzítette a müszereket a vertikális vizsgálathoz.

- Szegedi Karszt- és Barlangkutató Egyesülettől Bauer Márton volt segítségemre több balrang esetében is, nagyon sokat tanulhattam töle a barlangok geológiájáról, valamint bármilyen kéréssel, kérdéssel fordulhattam hozzá, mindig segítségemre volt.

Lukáts Lillának köszönöm, hogy a barlangban túrázó csoportok számának rögzítésével nagyon sokat segítet a Trió-barlang antropogén hatásának vizsgálatában.

Szeretnék köszönetet mondani az Unicomp $\boldsymbol{K} \boldsymbol{f t}$.-nek a müszerek szervizeléséért.

$\boldsymbol{A}$ Radosys $\boldsymbol{K} f t$.-nek köszönöm a felajánlásukat, a radon detektorokra, és az adatok kiolvasását.

A Barlangtani Osztálynak köszönöm a rengeteg munkáját, melyet a kutatási jelentések online elérésért tett. Egri Csabának és Kovács Richárdnak külön köszönöm, hogy kérdéseimre mindig gyorsan válaszolták, ezzel megoldván az aktuálisan felmerülő problémámat.

A bükki meteorológiai adatokat köszönöm az OMSZ Szolgáltatási Osztály szentléleki meteorológiai állomás mérései alapján az órás pillanatnyi hőmérséklet értékeit a 2012. és 2013. évekre vonatkozóan.

Szeretnék köszönetet mondani Fehér Katalinnak az ELTE Környezet- és Tájföldrajzi Tanszék tanszéki mérnökének, aki a Pál-völgyi-barlangnál található ELTE TTK Kőzettani és Geokémiai Tanszék Litoszféra Fluidum Kutató Labor (LRG) tulajdonában álló Meteorológiai állomás adatait bocsájtotta rendelkezésemre.

Szeretnék köszönetet mondani az angol nyelvi segítségért Dr. Puskás Irénnek, Kádár Anettnek, Ladányi Zsuzsannának és Koltai Gabriellának.

Krétiné Pölös Tímeának köszönöm a német nyelvórákat, valamint az irományaim korrektúrázását.

Szeretnék köszönetet mondani a Szegedi Tudományegyetem, Természeti Földrajzi és Geoinformatikai Tanszék vezetőjének, Prof. Dr. Mezősi Gábornak, aki helyet biztosítva számomra lehetővé tette, hogy doktori kutatásomat e tanszéken végezzem el. Szeretnék köszönetet mondani a Földrajzi és Földtudományi Intézet mindazon dolgozóinak, akik valamilyen formában segítségemre voltak az eltelt évek alatt, közülük kiemelném: Keveiné Bárány Ilonát, Fülöpné Dr. Szolnoki Zsuzsannát, Gál Norbertet, Dr. Henits Lászlót, Balázs Brigittát, Právecz Tamást, Csendes Bálintot.

Szeretnék köszönet mondani családomnak, édesanyámnak Muladi Istvánnénak, nagyszüleimnek Szörfi Sándornak és Szörfi Sándornénak, illetve keresztszüleimnek, Csárdás Endrének és Csárdásné Szőrfi Évának hálás vagyok minden segítségérért, bízva bennem mindvégig támogattak céljaim elérésében.

Utazásaim során köszönöm vendéglátóimnak hogy mindig segítségemre voltak és örömmel fogadtak: Kása Krisztina, Bauer család, Kréti család, Mecsek háza, Hajnal Ágnes, Ács-Kovács Milán, és Bujdosó Éva.

„.. A barlang nem mindig sötét, A lámpa ég, hát lemegyünk még, Nem szakadhat ránk az ég! ..."

A barlangkutatók éneke 


\section{Irodalomjegyzék}

Atkinson, T.C, (1983): Growth mechanisms of speleothems in Castleguard Cave, Columbian Icefields, Alberta, Canada. Arctic and Alpine Research, 15, 487-502.

Bárány-Kevei, I., Mucsi, L., (1995): Acidification and other karst soil processes in Hungary. Acta Carstologica, 24, 71-82.

BARIT Barlangkutató Csoport kutatási jelentés (2010):

http://www.termeszetvedelem.hu/_user/browser/File/barlangkutat\%C3\%A1si\%20jelent\%C3\%A9sek/20 10/barit_jeletes_2010.pdf

(2015.11.10.)

Barta, K., Tarnai, T., Bauer, M., (2012): A Nyugat-Mecseki-karszt általános jellemzése. In: Barta, K., Tarnai, T. (Szerk.): A Nyugat-Mecsek karsztja. Szeged: GeoLitera, 13-23.

Barta, K., Tarnai, T., 1997. Karsztkutatás az Orfüi Vízfö-forrás vízgyüjtő területén. Karszt és Barlang, I-II, 12-19.

Bauer, M., M.Tóth, T., (2015): Modeling microfracture geometry to the asses the function of a karst system (Vízfö spring catchment area, Western Mecsek Mountains, Hungary). Geologia Croatica, 68 (1), 1-9.

Bauer, M., M. Tóth, T., (2011): A mikrorés hálózat szerepe a barlangok fejlődésében az Orfüi Vízföforrás vízgyüjtőjén. In: Veress M., (Szerk.): Karsztfejlődés XVI. Szombathely: NYME Kiadó, 103-122.

Bekey Imre Gábor Barlangkutató Csoport, (1996): 1995 évi munkájáról, Jelentés, Budapest 39 p.

Berenguer-Sempere, F., Gómez-Lende, M., Serrano, E., Sanjosé-Blasco,de J.J., (2014): Orthothermographies and 3D modeling as potential tools in ice cave studies:the Peña Castil ice cave (Picos de Europa, Northern Spain). International Journal of Speleology, 43 (1), 35-43.

Bourges, F., Genthon, P., Genty, D., D'Hulst, D., (2014): Conservation of prehistoric caves and stability of their inner climate: Lessons from Chauvet and other French caves. Science of the Total Environment, 493, 79-91.

Bourges, F., Genthon, P., Mangin, A., D'Hulst, D., (2006a): Microclimates of L 'Aven d 'Orgnac and other French limestone caves (Chauvet, Esparros, Marsoulas). International Journal of Climatology, 26, 1651-1670.

Bourges, F., Mangin, A., D'Hults, D., Genthon, P., (2006b): La conservation de 1 'art parietal pr éhistorique des grottes, les raisons d 'un miracle. Bulletin de la Société Préistorique Ariége-Pyrénées, 61, 43-50.

Bourges, F., Mangin, A., D'Hulst, D., (2001): Carbon dioxide in karst cavity atmosphere dynamics: the example of the Aven d 'Orgnac (Ardeche), Comptes Rendus de L'Academie Des Sciences Serie II Fascicule A - Sciences de la Terre et des Planetes, 333, 685-692.

Böckler, D., Pflitsch, A., Killing-Heinze, M., (2012): Ein Verleich von Temperaturdatenloggern und Messensoren untersciedlicher Preisniveaus und Bauarten, hinsichlich ihrer Reaktionszeit, Ihrer Genauigkeit und ihrem Handling in der Höhlenklimatologie. In: Stünzi, H. (Ed.): Proceedings of the 13th National Congress of Speleology. Druckzentrum ETH-Zentrum, Zürich, 137-140.

Börcsök, P., (2000): Barlangi túravezetöi Ismeretek. Budapest: Barlang Bt.155 p.

Cigna, A.A., (1967): An analytical study of air circulation in caves. International Journal of speleology, 3, 41-45.

Crossbow, (2004): TELOSB MOTE PLATFORM.

http://www.willow.co.uk/TelosB_Datasheet.pdf

(2015.10.10)

Cullingford, C., (1953): British Caving. An Introduction to Speleology. London: Routledge. 
Csepregi, I., Gazda, A., (2014): Barlangokkal kapcsolatos jogi ismeretek. In: Dolgos, M., (Szerk.): Kutatásvezetői ismeretek. Budapest: MKBT Oktatási Szakosztály, 11-33.

Csomor, M., Zalavári, L., (1964): Barlangklíma mérések a Baradlában és a Béke-barlangban. Karszt és Barlang, 2, 45-51.

de Freitas, C., Littlejohn, R., Clarkson, T., Kristament, I.S., (1982): Cave climate: assessment of airflow and ventilation. Journal of Climatalogy, 2, 383-397.

Dénes, Gy., (2000): A magyar barlangkutatás története. In: Börcsök, P., (Szerk.): Barlangi Túravezetői Ismeretek I.rész. Budapest: Barlang Bt., 109-114.

Dezső, Z., Molnár, L., (2001): Barlangklíma és a radon viszonyok kapcsolata. Esztergom, Barlangkutatók Szakmai Találkozója, 1-8.

Fairchild, I.J., Baker, A., (2012): Speleothem Science-From Process to Past Environments, WileyBlackwell, Oxford, $432 \mathrm{p}$.

Filliponi, M., (2003): Das Klima der Schrattenhöhle: Auswertung einer 10-jährigen Messreihe. Zürich: Eidgenössische Technische Hochschule Zürich. 53.p.

Fodor, I., (2002): A barlangklíma-vizsgálatok történeti visszapillantásban. Karszt és Barlang, 19981999 I-II, 43-46.

Fodor, I., (1981): A barlangok éghajlati és bioklimatológiai sajátosságai. Akadémia Kiadó, Budapest, $190 \mathrm{p}$.

Fodor, I., (1980): Barlangklíma és terápia. In: Hazslinszky, T. (Szerk.): 70 éves a szerveztett magyar karszt-és barlangkutatás 1910-1980. Budapest: Magyar Karszt és Barlangkutató Társulat, 36-42.

Gádoros, M., (2000): Barlangmeteorológia dióhéjban. In: Barlangi túravezető ismeretek. I.rész jegyzet, 155. p.

Gruber, P., (2005): Az Aggteleki-karszt geológiai jellemzöi. http://rozsnyovidek.sk/files/2013/01/95-867-8760-geologia.pdf (2015.10.06.).

Hakl, J., Hunyadi, I., Csige, I., Géczy, G., Lénárt, L., Várhegyi, A., (1997): Radon transport phenomena studied in karst caves - International experiences on radon levels and exposures. Radiation Measurements, 28 (1-6), 675-684.

Hartman, P., (1961): Mine ventilation and air conditioning. New York: Ronald Press.

Herczeg, L., (2008): Irodaterek belső levegő minőségének értékelése A szén-dioxid koncentráció hatása az ember közérzetére és az irodai munka teljesítményére. Doktori értekezés. Budapesti Müszaki és Gazdaságtudományi Egyetem, Budapest. 122 p.

Hevesi, A., (2003): Bükkvidék. In: Székely, K. (Szerk.): Magyarország fokozottan védett barlangjai. Budapest, Mezőgazda kiadó, 99-106.

Hevesi, A., (1978): A Bükk szerkezet- és Felszínfejlődésének vázlata. Földrajzi Értesítő, 169-209.

Hevesi, A., (1991): Magyarország karsztvidékeinek kialakulása és formakincse. Földrajzi közlemények, 39 (3-4), 99-120.

Hir, J., (1985): Hajnóczy-barlang üledékei. Karszt és Barlang, I-II, 21-40.

Horváth, Á., (2013): Országos Meteorológiai Szolgálat A március 14-15-i hóvihar meteorológiai elemzése.

http://www.met.hu/ismeret-tar/erdekessegek_tanulmanyok/index.php?id=597 (2015.02.25).

Horváth, Á., Nagy, A., (2014): Országos Meteorológiai Szolgálat Atlanti viharciklonok 2014. február közepén.

http://met.hu/ismerettar/erdekessegek_tanulmanyok/index.php?id=969\&hir=Atlanti_viharciklonok_201 4._februar_kozepen (2016.02.25.)

Horváth, T., (1984): A barlangterápia, mint légzésrechalbilitációs módszer hatása a légúti obstruckiókra. Balneológia, Rehabilitáció, Gyógyfürdöügy 5, 167. 
Jakucs, L., (1971): A karsztok morfogenetikája-A karsztfejlödés varienciái. Budapest: Akadémia kiadó. 310. p.

Jakucs, L., (1959): A Béke-barlang gyógyhatásvizsgálatának első ereményei. Természettudományi Közlöny, I, 25-39.

Kadić, O., (1920): A pálvölgyi cseppkő-barlang Budapest határában. A természet, 16 (I.-II.), 16-20.

Kaffai, O., Imecs, Z., (2008): Mikroklimatológiai mérések a Körösrévi Zichy-barlangban. In: Veress, M. (Szerk.): Karsztfejlódés XIII. Szombathely: NYME Kiadó, 269-277.

Kárpát, J., Takácsné, B.K., (1983): Pál-völgyi-barlang. Budapest: Magyar Karszt és Barlangkutató Társulat.

Kessler, H., (1941): Az aggteleki barlang leirásaés feltárásának története. Mérnökök Nyomdája 56 p.

Keveiné, B.I., (2009): A karsztok ökológiai rendszere. Szeged: JATEPress. 121 p.

Kordos, L., (2002): A bükki barlangok ősmaradványai. In: Baráz, Cs. (Szerk.): A Bükki Nemzeti Park hegyek, erdők, emberek. Eger: Bükki Nemzeti Park, 195-203.

Kordos, L., (1984): Magyarország barlangjai. Budapest: Gondolat Kiadó. 315. p.

Kordos, L., (1970): Klímamegfigyelések a barlangok bejárat zónájában. Karszt és barlang, I, 31-34.

Kovács, J., Müller, P., (1980): A Budai-hegyek hévizes tevékenységének kialakulása és nyomai. Karszt és Barlang, II, 93-98.

Kovács, R., Reszegi, A., Szabó, Z., (2011): Karszt.hu.

http://www.karszt.hu/budai_hegyseg_pal_volgyi_osszekotes.htm (2013.03.05.)

Kraus, S., (1982): A Budai-hegység hévizes barlangjainak fejlődéstörténete. Karszt és Barlang, I, 2934.

Kraus, S., (2000): Földtani adatgyüjtés. In: Börcsök, P. (Szerk.): Barlangi Kutatásvezetö Ismeretek. Budapest: Barlang Bt., 7-34.

Leél-Őssy, Sz.,(2014): Kristálybarlang a nagyváros alatt, A budapesti József-hegyi-barlang. Gelitera, Szeged, $190 \mathrm{p}$.

Leél-Össy, Sz., Surányi, G., (2003): The peculiar hydrothermal caves in Budepest (Hungary). Acta Geologica Hungarica, 46, 407-436.

Leél-Össy, Sz., (1995): A budai Rózsadomb és krnyékének különleges barlangjai. Földtani Közlöny, 125 (3-4), 363-432.

Lengyel, Z.,(2007): ZigBee hálózat analizátor,TDK dolgozat. Budapest: Budapesti Mőszaki és Gazdaságtudományi Egyetem. 60.p.

Linden, P.F., (1999): The fluid mechanics of natural ventilation. Annual Review of fluid Mechenaics, 31, 201-238.

Lippmann, L., Kiss, K., Móga, J., (2008): Az Abaliget-Orfüi Karszt karsztos felszínformáinak vizsgalatata térinformatikai módszerekkel. In: Veress M. (Szerk.): Karsztfejlödés XIII.. Szombathely: NYME Kiadó, 151-166.

Litschmann, T., Rožnovský, J., Středa, T., Středová, H., Hebelka, J. (2012): Temperature and humidity conitions of Mococha Abyss. Contributions to Geophysics and Geodesy, 42 (3), 227-242.

Losonci, G., (2014): A huzat és a barlangkutatás. In: Dolgos M. (Szerk.): Kutatásvezetői ismeretek. Budapest: MKBT Oktatási Szakosztály, 167-180.

Lovászi, Gy., (1971): Adatok az Abaligeti-kaszt geomorfológiai és hidrológiai jellmezéséhez. Földrajzi értesitó, 20 (3), 283-296.

Markó, L., Jakucs, L., 1956. A barlangi légáramlás keletkezése. Hidrológiai Közlöny, 36 (4), 314. 
Maróti, M., Kusy, B., Simon, G., Lédeczi, Á., (2004) The Flooding Time Synchronization Protocol. In: Stankovic, J.A. (Ed.): 2nd ACM Int. Conf. on Embedded Networked Sensor Systems (SenSys). New York: ACM Press, 39-49.

Miklós, G., (1978): A Hajnóczy-barlang mikroklímája. Karszt és barlang, I-II, 11-18.

Moss, D., Hui, J., Klues, K., Low Power Listening.

http://www.tinyos.net/tinyos-2.x/doc/html/tep105.html (2015.12.04.)

Mucsi, L., Muladi, B., Henits, L., Farsang, A.,( 2014): Large Scale UHI Mapping Based on Spatial Information Provided by Young Volunteers. CARPATHIAN JOURNAL OF EARTH AND ENVIRONMENTAL SCIENCES, 9 (2), 31-43.

Mucsi, L., Balog, A., Juhász, G., (2004): Interaktív, 3D-s barlangi információs rendszer a világhálón. Geodézia és Kartográfia, 56 (12), 3-8.

Mucsi, L., (1992): Karsztmorfológiai vizsgálatok Odorvár környékén, Különös tekintettel a különbözö közetadottságú felszinekre, Szeged: Szegedi Tudományegyetem. 94. p.

Mucsi, L., (1984): Kutatások és munkálatok az Óriás-terem tetején, Tiszaföldvár: Jelentés a Hajnóczy József Barlangkutaó Csoport 1983. évi munkájáról. 1-10.

Muladi, B., Mucsi, L., (2014): Investigation of the spatial and temporal trends of the air temperature of the Hajnóczy cave in the Bükk mountains. Geographica Pannonica, 18 (3), 51-61.

Muladi, B., Mucsi, L., (2013a): Investigation of Daily Natural and Rapid Human Effects on the Air Temperature of The Hajnóczy Cave in Bükk Mountains. Journal of Environmental Geography, 6 (3-4), 21-29.

Muladi, B. Csépe,Z., Mucsi, L., Puskás, I., Koltai, G., Bauer, M., (2013b): Climatic features of different karst caves in Hungary. In: Filippi, M., Bosák, P. (Eds.): 16th International Congress of Speleology. Prague: Czech Speleological Society, 432-438.

Muladi B, Mucsi L., 2013c. Látogató csoportok hatása a Trió-barlangban, In: Galbács Z (szerk.)

Proceedings of the 19th International Symposium on Analytical and Environmental Problems. 72-75.

Muladi, B., Csépe, Z., Mucsi, L., (2013d): Barlangklimatológiai mérések két különböző karsztterületen elhelyezkedő magyarországi barlangban. In: Veress, M. (Szerk.): Karsztfejlödés XVIII. Szombathely: NYME kiadó, 127-136.

Muladi, B., Csépe, Z., Mucsi, L., Puskás, I., (2012): Application of wireless sensor networks in Mecsek Mountain's caves. In: Stünzi, H. (Ed.): Proceedings of the 13th National Congress of Speleology. Zürich: ETH, 131-136.

Muladi, B., Csépe, Z., (2012): Vezeték nélküli szenzorhálózatok alkalmazása barlangi körülmények között. Karszt és Barlang, I-II, 29-39.

Muladi, B., (2011): Vezeték nélküli szenzorhálózat alkalmazása térbeli jelenségek pontszerü mérésénél (Diplomadolgozat). Szeged: SZTE.66.p.

Nagy, A., Nagy, G.D., (2013): Harcsaszájú-Hideglyuk-barlangrendszer. In: Mindszenti A. (Szerk.): Budapest Földtani értékek és az ember városgeológiaia tanulmányok. Budapest: ELTE Eötvös Kiadó, 218.

Nagy, A., (2012): A Gábor Áron barlang leárása, Budapest: Kuatási jelentés Szabó József barlangkutató Szakosztály.

Nagy, A., (2010): Hideg-lyuk 4762/41,. Budapest: Kutatási jelentés Szabó József Barlangkutató Szakosztály.

Nagy, A., Nagy, G.D., (2010): A Harcsaszájú-Hideg-lyuk barlangrendszer születése. Karszt és Barlang, I-II, 88-94.

Nagy, G.D., (2014): Harcsaszájú-barlang. In: Slíz, Gy. (Szerk.): Felfedezédek a föld alatt. Budapest: Némedy Nyomda, 84-97. 
Nagy, H.É., (2012): Radonkoncentráció dinamikájának és forrásainak vizsgálata budai-hegységi barlangokban. Budapest: Litoszféra Fluidum Kutató Labor. 137.p.

Pátkai, Zs., Simon, A. Kolláth, K., (2013): Országos Meteorológiai Szolgálat Hózápor-dömping Budán. http://met.hu/ismeret-tar/erdekessegek_tanulmanyok/index.php?id=578\&hir=Hozapor-domping_Budan (2016.02.25.)

Pflitsch, A., Grebe, C., Grudzielanek, M., (2012): About the use of thermal imaging in cave micrometeorological studies. In: Stünzi, H (Ed.): Proceedings of the 13th National Congress of Speleology. Zürich: ETH, 141-144.

Price M. (2014): Creating Faulted Geologic Surfaces with ArcGIS

http://www.esri.com/esri-news/arcuser/summer-2014/creating-faulted-geologic-surfaces-with-arcgis (2016.01.10.)

Rajczy, M., (2000): Klimatológiai mérések. In: Péter, B. (Szerk.): Barlangi kutatás vezetői ismeretek. Budapest: Barlang Bt., 137-144.

Rántó, A., Tóth, N., (2010): A Magyar Állami Természetvédelem hivatalos honlapja.

http://www.termeszetvedelem.hu/_user/browser/File/barlangkutat\%C3\%A1si\%20jelent\%C3\%A9sek/20 10/ranto_andras_2010.pdf

(2016.02.17.)

Rónaki, L., (1970): Vízfö-forrás és barlangjának kutatása. Karszt és Barlang, I, 25-30.

Schweitzer, F., (2003): A Vértes- és a Dunazug-hegyvidék. In: Székely, K. (Szerk.): Magyarország fokozottan védett barlangja. Budapest: Mezőgazda Kiadó, 235-240.

Sensiron, (2011a): Datasheet SHT21 Humidity and Temperature Sensor IC. The sensor company, 3, 114.

Sensiron, (2011b): Datasheet Filter Cap SF2 For Humidity and Temperature Sensor SHT2x. The sensor company, 2, 1-5.

Smith, A.C., Wynn, P.M., Barker, P.A., (2013): Natural and anthropogenic factors which influence areosol distribution in Inleborough Show Cavw, UK. International Jornal of Speleology, 42 (1), 49-56.

Somogyi, Gy., Varga, Zs., Németh, Gy., Pálfalvi, I., Gerzson, I., (1983): Radon mérés a Hajnóczybarlangban. Izotóptechnika, 26-38.

Stieber, J., (2014): Klímelemeek, azok mérési módszerei és mérésének eszközei. In: Dolgos, M. (Szerk.): Kutatásvezetői ismeretek. Budapest: MKBT Oktatási Szakosztály, 342-366.

Stieber, J., Leél-Őssy, Sz., (2015): Megváltozott, vagy csak visszaváltozott a Béke-barlang klímája?. In: Veress, M. (Szerk.): Karsztfejlödés XX.. Szombathely: NYME Kiadó, 263-282.

Surányi, G., (2008) A magyar állami természetvédelem hivatalos honlapja-Barlangkutatási jelentések. http://www.termeszetvedelem.hu/_user/browser/File/barlangkutat\%C3\%A1si\%20jelent\%C3\%A9sek/20 08/ariadne_cholnoky_2008.pdf

(2015.12.20.)

Szabó, Z.P., (1953): Két mecseki karsztforrás vizsgálata Komló és Pécs vízellátása szempontjából. Földrajzi Közlemények, 77 (3-4), 161-189.

SZKBE, (2002): A magyar állami természetvédelem hivatalos honlapja.

http://www.termeszetvedelem.hu/_user/cave_images/4120-71_1191497238.jpg (2015.02.26.)

Testo, (2015):

http://www.testo.hu/termek_reszletek/0560+4053/\#tab-8 (2015.04.30.)

Tobin, B.W., Hutchins, B.T., Schwartz, B.F., (2013): Spatial and temporal changes in invertebrate assemlage structure from entrance to deep-cave zone of a temperate marble cave. International Jornal of Speleology, 42 (3), 203-214.

Townson, R., (1797): Travels in Hungary. London

Trombe, F., (1952): Trait é de Sp é leologie. Paris: Payot. 
Unicomp, (2011): Users Manual v0.1 - UCMote mini. Székesfehérvár: Unicomp.

Varga, Cs., (1978): Az Odorvári Hajnóczy-barlang. Karszt és Barlang, I-II, 7-10.

Varga, Cs., (2003): Hajnóczy-barlang. In: Székely, K. (Szerk.): Magyarország fokozottan védett barlangjai. Budapest: Mezőgazda Kiadó, 200-204.

Veress, M., (2009): Investigation of covered karst form development using geophysical measurements. Zeitschrift für Geomorphologie, 53, 469-486.

Vincze, E., Lakatos, M., Tóth, Z., (2013): Országos Meteorológiai Szolgálat 2013 nyarának éghajlati áttekintése.

http://met.hu/ismeret-

tar/erdekessegek_tanulmanyok/index.php?id=834\&hir=2013_nyaranak_eghajlati_attekintese (2015.02.25.)

Virág, M., (2013): A Szépvölgy és a Rózsadomb környékének nagy barlangjai. In: Mindszenty, A. (Szerk.): Budapest Földtani értékek és az ember városgeológiai tanulmányok. Budapest, ELTE Eötvös Kidó, 208-212.

Virág, M., Takácsné, B.K., Leél.-Össy. Sz., (2013): A barlangok felfedezése és a rózsadombi kisbarlangok. In: Mindszenty, A. (Szerk.): Budapest Földtani értékek és az ember városgeológiai tanulmányok. Budapest, ELTE Eötvös Kiadó, 206-208.

Wein, Gy., (1977): A Budai-hegység tektonikája. A Magyar Állami Földtani Intézet alkalmi kiadványa, 76.p.

Wigley, T., (1967): Non-steady flow through a porus medium and cave breathing. Journal of Geophysical Research, 72, 3199-3205.

Wigley, T., Brown, M., (1976): The Physics of caves. In: Ford, T., Cullingford, C. (Eds.): The Science of Speleology. London: Academic Press, 329-358.

Zámbó, L., (1993): Karst corrosion measuring station in the catchment of the Béke Cave, Aggtelek karst, North-Hungary. Annales Universitatis Scientiarum Budapestinensis de Rolando Eötvös Nominatae. Sectio geographica., 22-23, 183-195.

Zelinka, J., Stieber, J., (2014): A barlangrendszer és környékének klímája. In: Gruber, P., Gaál, L. (Szerk.): A Baradla-Domica barlangrendszer. Jósvafó: Aggteleki Nemzeti Park Igazgatóság, 211-231.

Zentai, Z., (2007): Érdekességek a Pál-völgyi-barlang kutatástörténetéből. Karsztfelődés XII., 25-35.

1996. évi LIII. törvény - a természet.

http://net.jogtar.hu/jr/gen/hjegy_doc.cgi?docid=99600053.TV (2015.03.10.) 


\section{Ábrajegyzék}

1. ábra Baradla-barlang nyomáskiegyenlítő légáramlata (Markó, Jakucs, 1956).

2. ábra A barlangi léghőmérséklet rétegződésének vázlatos ábrázolása (Smith et al., 2013 után módosítva) ...

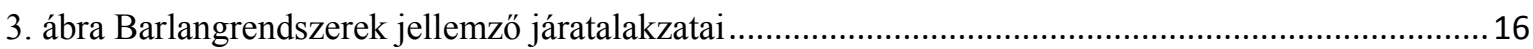

4. ábra Barlang morfológiai genetikai variációk (Fairchild, Baker, 2012 után módosítva).....................17

5. ábra A járatok jellegének csoportosítása (Börcsök, 2000 után módosítva) ……………………........ 18

6. ábra Rendszer változásának típusai az idő függvényében (Fairchild, Baker, 2012 után módosítva)... 23

7. ábra A légáramlás sematikus vázlatai különböző barlangrendszerekben (Fairchild, Baker, 2012 után módosítva)

8. ábra Sematikus ábra a több bejáratú, szűkület nélküli barlangrendszer légáramlásáról a

léghömérséklet és a tengerszint feletti magasság függvényében (Filliponi, 2003 után módosítva).........25

9. ábra Sematikus ábra a több bejáratú, szükülettel rendelkezö barlangrendszer légáramlásáról a

léghőmérséklet és a tengerszint feletti magasság függvényében (Filliponi, 2003 után módosítva).........25

10. ábra Odorvár és az Odor-hegy geológiai felépítése, és a Hajnóczy-barlang keresztmetszete (NyDNy-

KÉK irányú metszet) Szerkesztette: Muladi B., Mucsi L. Varga Cs. (1989) alapján ................................26

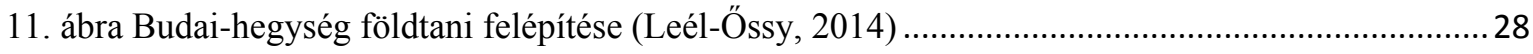

12. ábra A nyugat-mecseki antiklinális vázlatos földtani felépítése (Barta, et al., 2012), valamint a

barlangok helyzete a karszton (Szerkesztette: Muladi, Barta alapján)...................................................2 29

13.ábra A Hajnóczy-barlang léghőmérsékletének vizsgált szakasza, a vizsgálati pontok, azok tengerszint feletti magassága, valamint a keresztmetszete, és azok elnevezései.

14. ábra Optikai és hőfotó egymásra helyezve az Odorvárról. A felvétel déli Irányból a Mákszemről készült (Rántó \& Tóth, 2010)

15. ábra A Szép-völgyi-barlangrendszer térképe, és felfedezésének szakaszai (Kovács, et al., 2011) ....34

16. ábra A Pál-völgyi-barlang léghőmérsékletének vizsgált szakasza, a vizsgálati pontok, valamint a föbb járatok keresztmetszete, és azok elnevezései.

17. ábra A Hideg-lyuk léghőmérsékletének vizsgált szakasza, a vizsgálati pontok, valamint a föbb járatok keresztmetszete, és azok elnevezései.

18. ábra A Harcsaszájú-barlang vizsgált pontjai keresztmetszeti, és alaprajzi térképen valamint a járatok

elnevezései.

19. ábra A Trió-barlang alaprajzi térképén jelölt müszerek helye, és tengerszint feletti magasságuk, valamint a járatok keresztmetszetei és azok elnevezése. (SZKBE, 2002 után módosítva )....................... 41

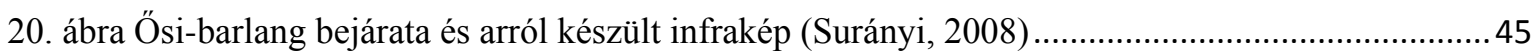

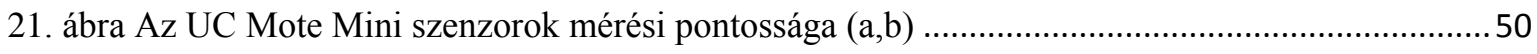

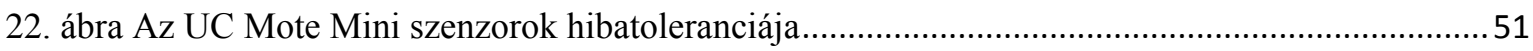

23. ábra Az UC Mini Mote szenzorral rögzített hömérséklet és páratartalom adatok …...........................52

24. ábra Az UC Mini Mote szenzorral rögzített hőmérséklet és páratartalom adatok ................................52

25. ábra A Hajnóczy-barlang vizsgált pontjainak tengerszint feletti magassága ......................................55

26. ábra A Hajnóczy-barlang vizsgált pontjainak alapstatisztikai értékei 2012.03.11-2013.04.10. között

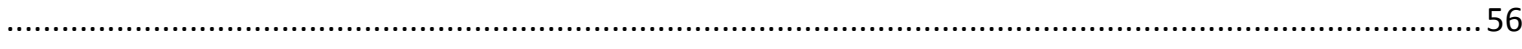

27. ábra A Hideg-lyuk vizsgált pontjainak tengerszint feletti magassága …........................................57

28. ábra A Hideg-lyuk vizsgált pontjainak alapstatisztikai értékei 2012.04.20-2013.12.07. között ........58

29. ábra A Pál-völgyi-barlang 4 csoportba osztott vizsgált pontjainak tengerszint feletti magassága......59

30. ábra A Pál-völgyi-barlangban az 1. csoport vizsgált pontjainak alapstatisztikai értékei 2013.04.24-

2014.04.27.között 
31. ábra A Pál-völgyi-barlangban az 2. csoport vizsgált pontjainak alapstatisztikai értékei 2013.04.24-

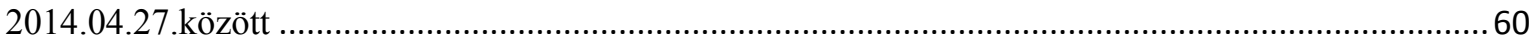

32. ábra A Pál-völgyi-barlangban az 3. csoport vizsgált pontjainak alapstatisztikai értékei 2013.04.-

2014.04.27.között

33. ábra A Pál-völgyi-barlangban az 4. csoport vizsgált pontjainak alapstatisztikai értékei 2013.04.24-

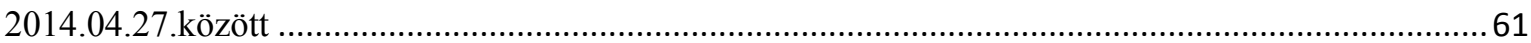

34. ábra A Harcsaszájú-barlang vizsgált pontjainak tengerszint feletti magassága .................................62

35. ábra A Harcsaszájú-barlang vizsgált pontjainak alapstatisztikai értékei 2013.04.28-2013.06.10

között

36. ábra A Trió-barlang vizsgált pontjainak tengerszint feletti magassága ............................................63

37. ábra A Trió-barlang vizsgált pontjainak alapstatisztikai értékei 2012.04.20-2012.06.17 között .......64

38. ábra A Hideg-lyuk Gábor Áron bejárata vizsgált pontjainak tengerszint feletti magassága ................65

39. ábra A Hideg-lyuk Gábor Áron bejáratának vertikális hőmérséklet alapstatisztikai értékei

2012.06.11-2012.06.25 között.

40. ábra A Hideg-lyukban a Rézágyú-teremben elhelyezett szenzorok keresztmetszeti és alaprajzi nézetben

41. ábra A Hideg-lyukban a Rézágyú-terem vertikális megfigyeléseinek alapstatisztikai értékei

2013.06.11.-2013.06.25 között.

42. ábra A Hajnóczy-barlang hőmérsékletének éves menete (2012.március-2013.április) Másodlagos tengelyen: 1-Bejárat fölött fán, 2- Bejárat után, és a Szentléleki meteorológiai állomás adatai

43. ábra A Hideg-lyuk hőmérsékletének éves menete (2012. május-2014 április) Másodlagos tengelyen:

1-Alsó bejárat, Felszín adatai

44. ábra Hideg-lyuk radon szintjének két mérési időszaka 2012.09.11.-10 21. valamint 2013.02.06.-

04.27. az összes vizsgálati pontban.

.75

45. ábra Hideg-lyuk radon szintje 2013.04.27.-2013. 10 21. közötti időszakban 5 db vizsgálati pontban

46. ábra A Hajnóczy-barlangba leszálló csoportok létszáma 2012.06.1.1................................... 76

47. ábra A Hajnóczy-barlang nyári mérése során elhelyezett szenzorok 2012-ben .................................. 78

48. ábra A Felszín és a Bejárat (B1) hőmérséklete ........................................................................ 78

49. ábra A Bejárat környéke (B2-B3), Füstösök (B4-B5), Rom-terem (B6-B7) 2012. 06.30-07.08 ...... 79

50. ábra A Lapos-terem (D1) Depó (D2,D3) és a Nagy-terem (D4) hőmérséklet adatai 2012.06.30-

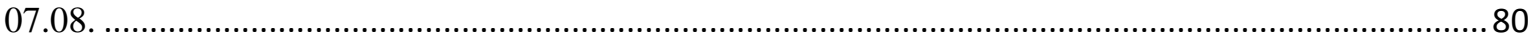

51. ábra A Leyla (L1, L2,L3,L4) és a Mandula (M1,M2) hőmérséklet adatai 2012. 06.30-07.08..........81

52. ábra Az Alsó-Galéria (G1,G2), és a Felső Galéria (G3,G4,G5,G6,G7) hőmérséklet adatai 2012.

$06.30-07.08$

53. ábra Az Óriás-terem hőmérséklet adatai (Ó1-Ó7) 2012. 06.30-07.08. .............................................. 83

54. ábra A Trió-barlang hőmérsékletei és a Pécsi meteorológiai állomás csapadék adata 2012.04.20

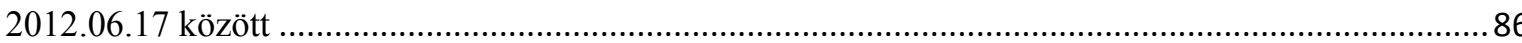

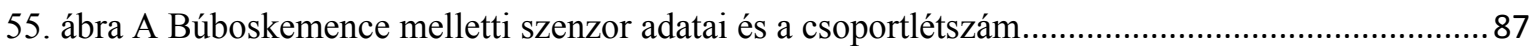

56. ábra A Búboskemencénél rögzített 3 kutatócsoport által okozott hőmérséklet-emelkedés 2012.05.06.

57. ábra A Pecsétnyomóban történt hőmérséklet-változások a bontások ideje alatt, 2013.10.22-12.03.

között

58. ábra A Hajnóczy-barlangot fedő kőzet és talaj vastagsága a járatok és termek fölött .........................90

59. ábra A Hajnóczy-barlang légkörzése modellje a téli hónapokban ..................................................... 91

60. ábra A Hajnóczy-barlang légkörzés modellje a nyári hónapokban................................................92

61. ábra A Hideg-lyuk hőmérsékletének térbeli eloszlása és légáramlása a nyári hónapokban ...............95

62. ábra A Hideg-lyuk hőmérsékletének eloszlása és légkörzése a téli hónapokban................................96 
63. ábra A Pál-völgyi-barlang vizsgált pontjai átlaghömérséklet alapján, valamint a járatok a

hömérséklet-változás alapján történt csoportosítása (vizsgálati időszak: 2013.04.24-2014.04.27.) .......98

64. ábra A Pál-völgyi-barlang légkörzése téli hónapokban (hőmérséklet adatok 2014.01.12. állapotot

mutatják)

65. ábra A Pál-völgyi-barlang légkörzése nyári hónapokban (hőmérséklet adatok 2013.07.03-i állapotot

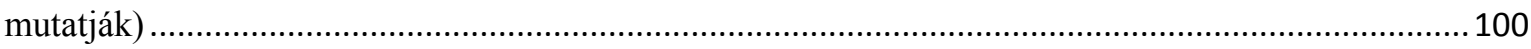

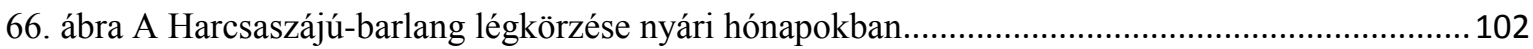

67. ábra A Pál-völgyi-barlangrendszer vizsgálati szakaszai és az azok fölötti talaj- és kőzet réteg

vastagsága

68. ábra A Harcsaszájú-barlang, Hideg-lyuk légáramlás észlelése, és a Pál-völgyi sziklaüreg

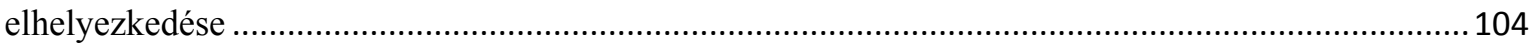

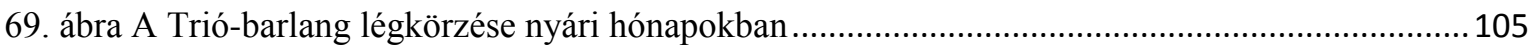

70. ábra A Trió-barlangot fedő kőzet és talaj vastagsága ……………….......................................... 106

\section{Táblázatjegyzék}

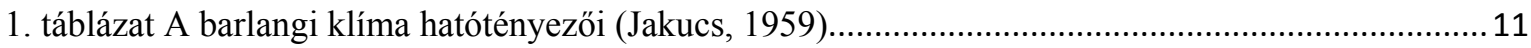

2. táblázat $\mathrm{CO}_{2}$ Egészségügyi hatás (Herczeg , 2008) …………………...................................... 13

3. táblázat A levegőmozgások összesítése a fizikai törvények alapján a barlangban és a körülötte lévő

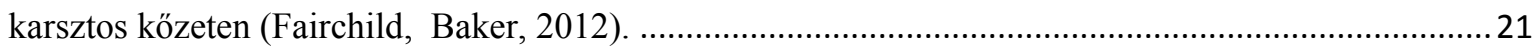

4. táblázat Beaufort-fokozat (https://www.met.hu/ismertetok/Beaufort-skala.pdf) ...............................22

5. táblázat Barlangi paraméterek méréstechnológiai tartományai (Fairchild, Baker, 2012) ..................... 43

6. táblázat A vezeték nélküli szenzorok összehasonlítása, a TelosB (CROSSBOW, 2004) fejlesztett

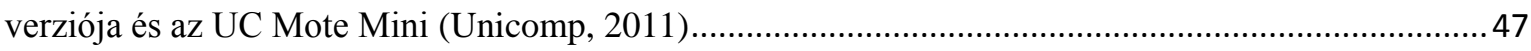

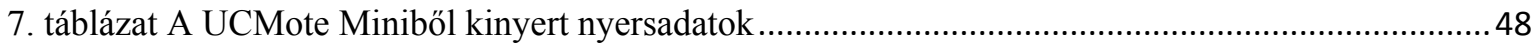

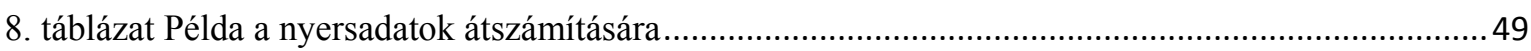

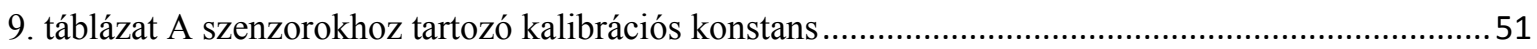

10. táblázat A Hajnóczy-barlang évszakonkénti hőingása, és az évszakokban jellemző napi hőingás

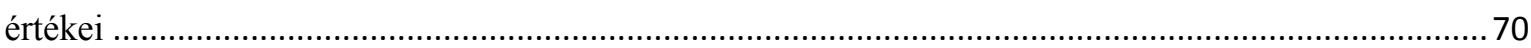

11. táblázat A Hideg-lyuk évszakonkénti hőingása, és az évszakokban jellemző napi hőingás értékei .. 73

12. táblázat A Hajnóczy-barlang különböző szakaszainak höterhelése adott csoportlétszám hatására ...84 
Melléklet 


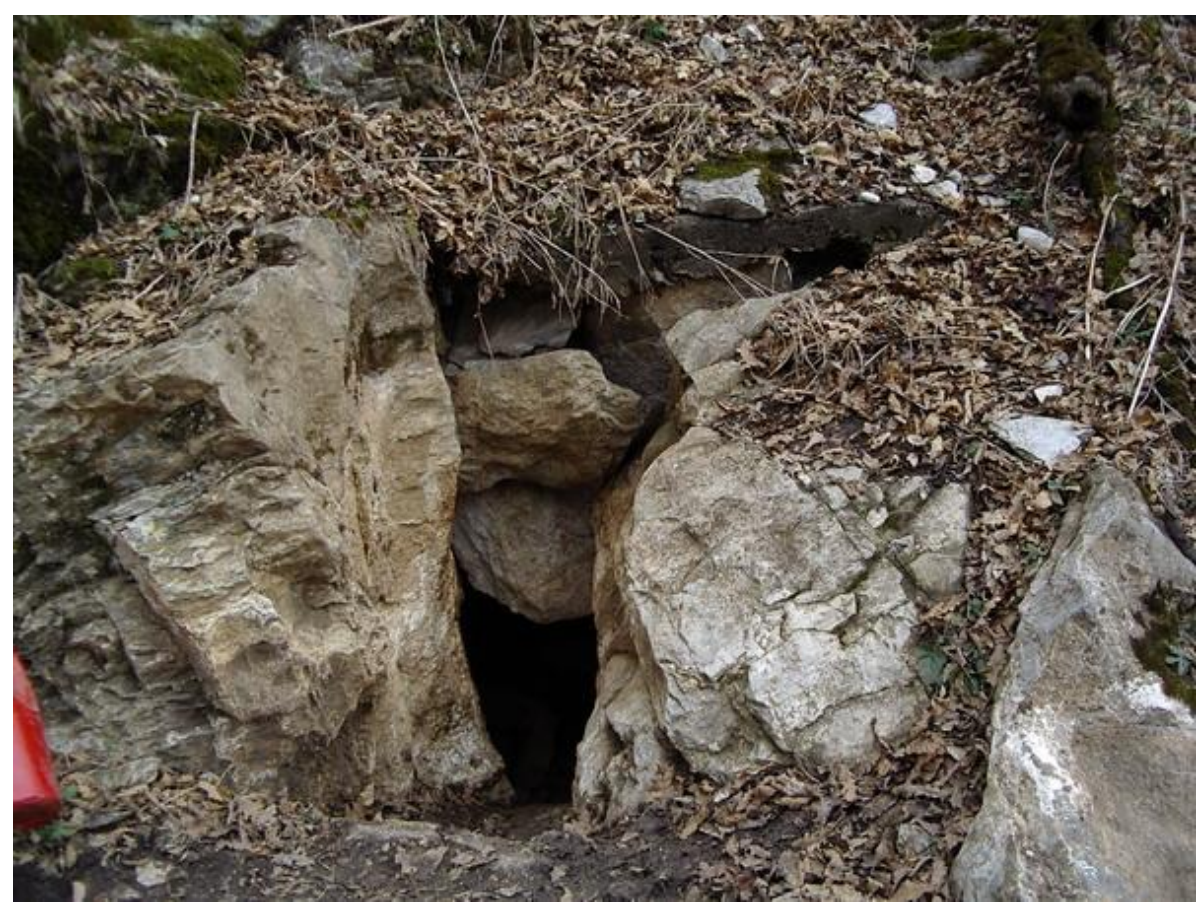

1. melléklet A Hajnóczy-barlang bejárata (Forrás Természetvédelem ${ }^{1}$ )

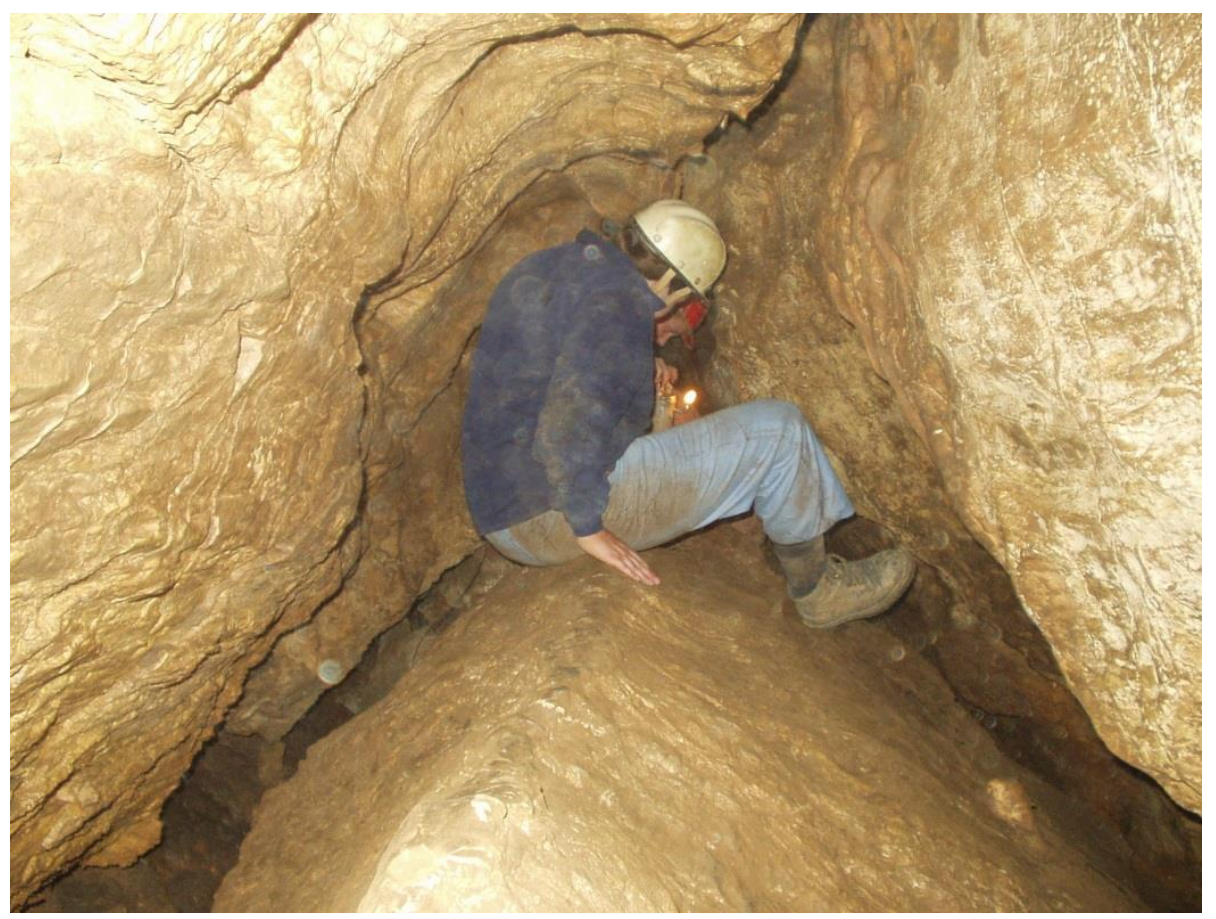

2. melléklet A Hajnóczy-barlangban található Háztető (Forrás:Varga Csaba)

\footnotetext{
${ }^{1}$ http://www.termeszetvedelem.hu/_user/cave_images/5382-2_1234796956.jpg
} 


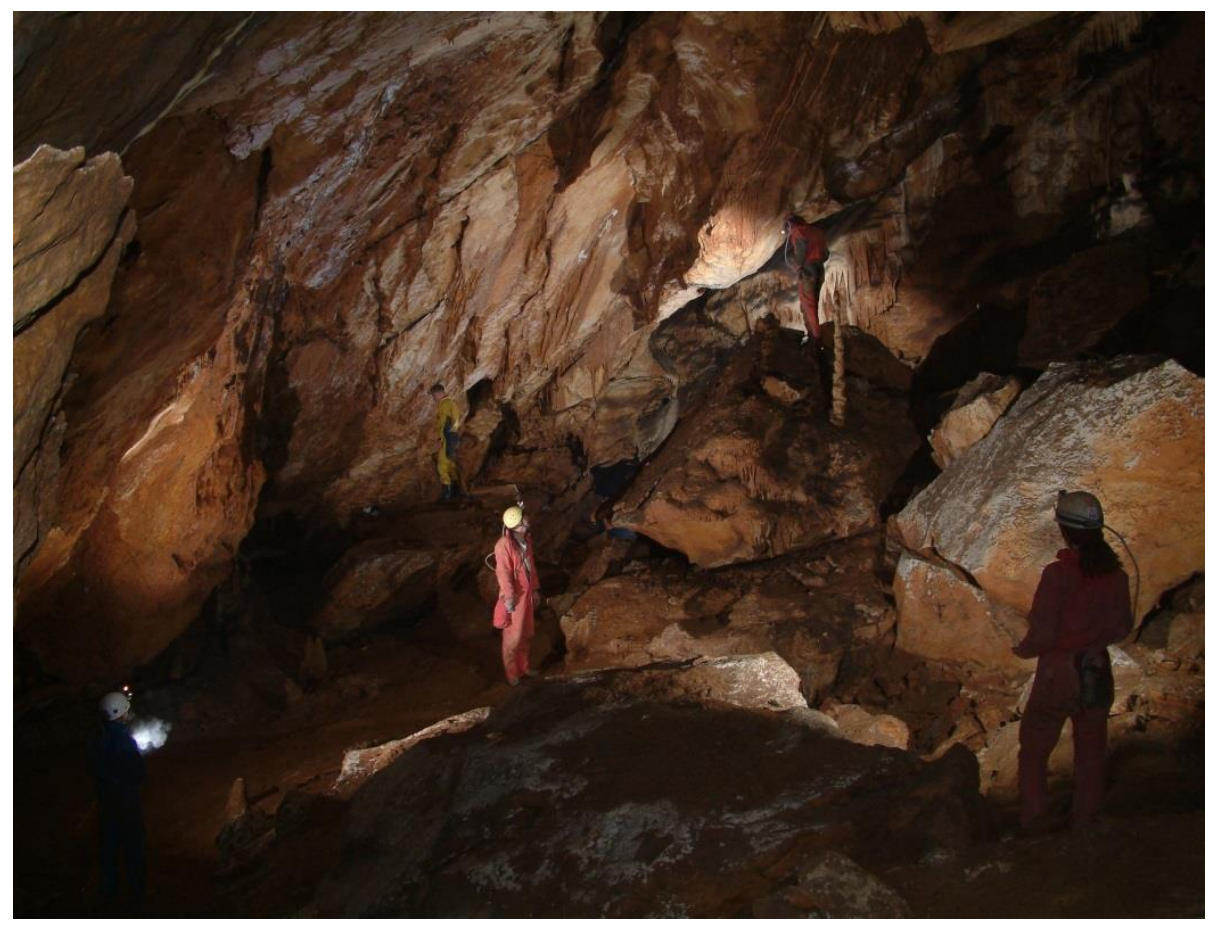

3. melléklet A Hajnóczy-barlang Nagy-terme (Forrás: Kocsis Ákos)

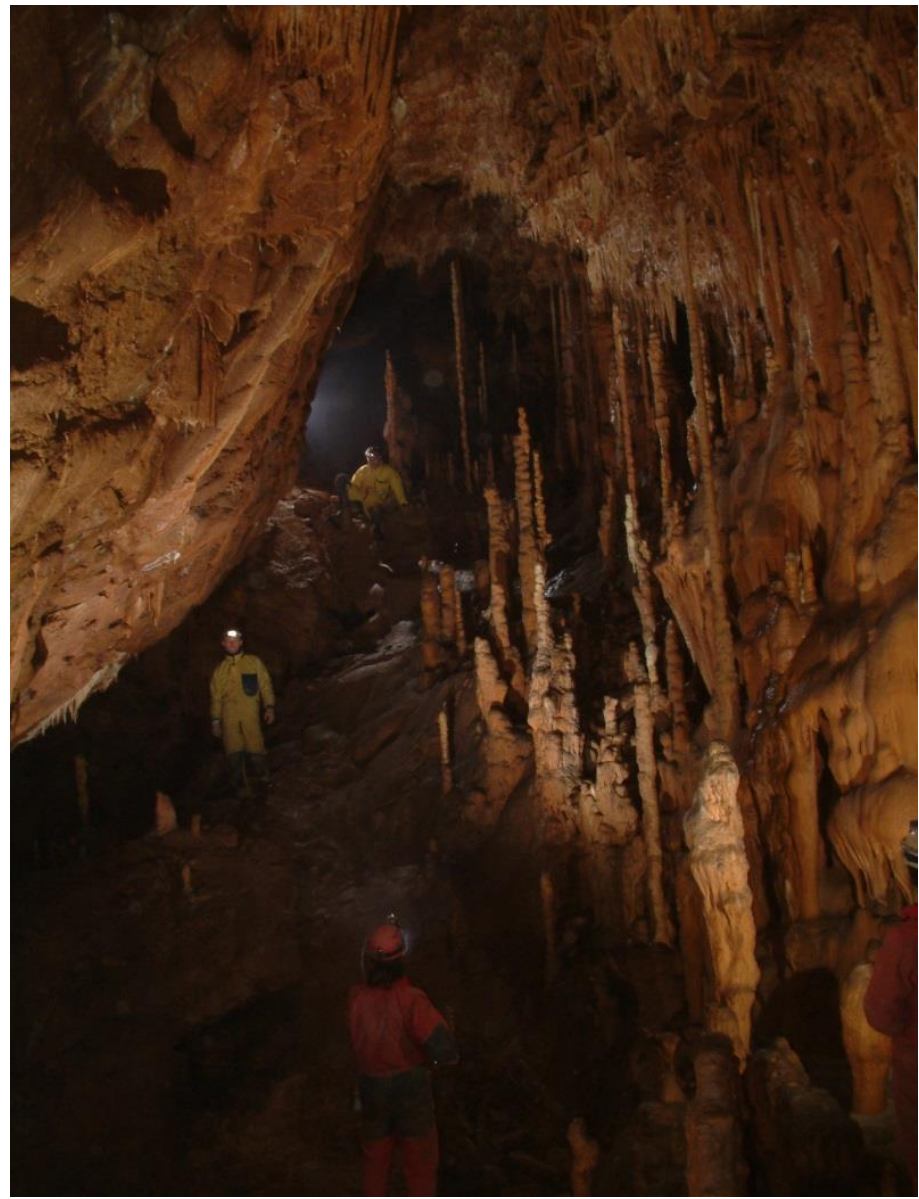

4. melléklet A Hajnóczy-barlang Galéria szakasza (Forrás: Kocsis Ákos) 


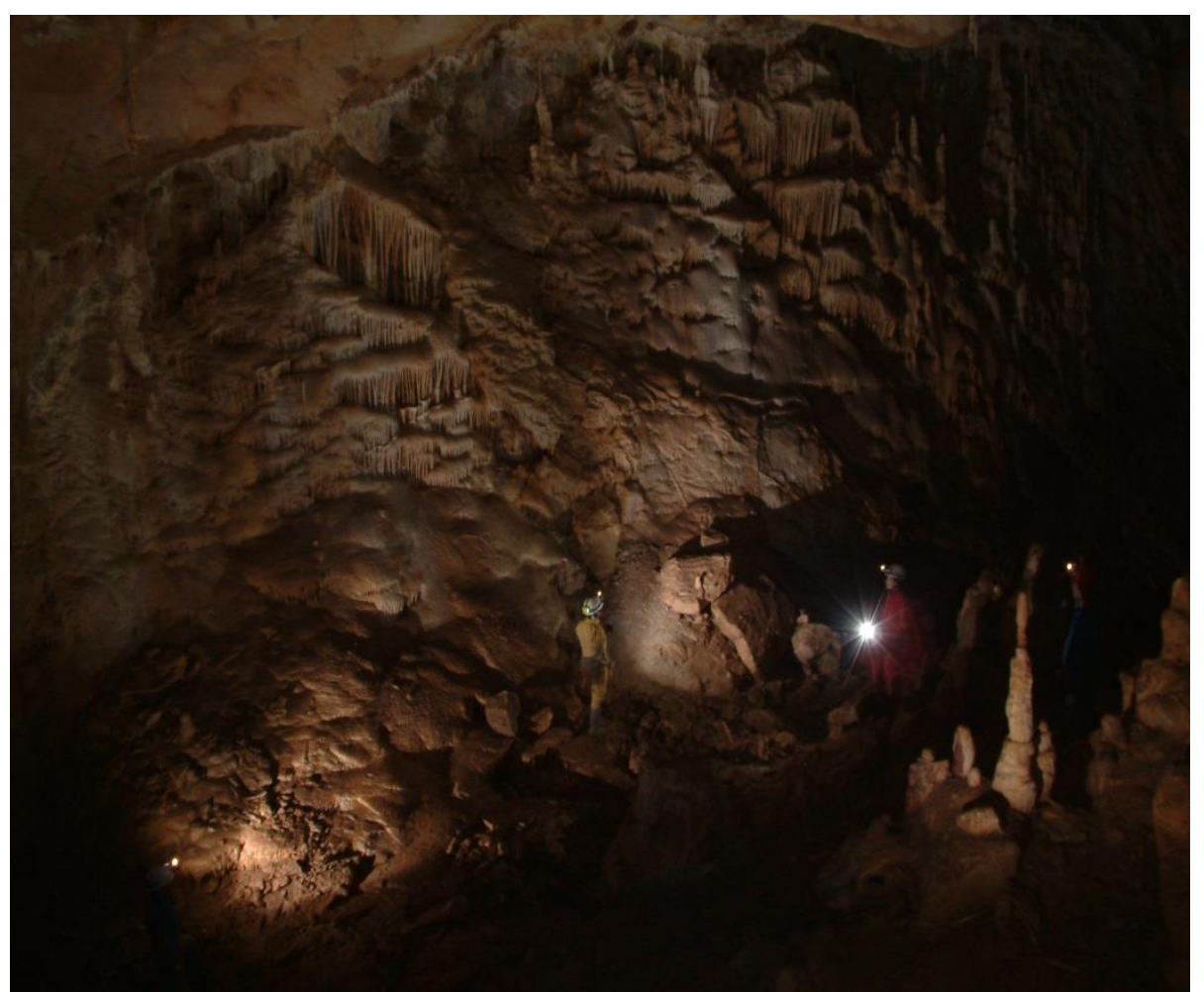

5. melléklet A Hajnóczy-barlang Óriás-terme (Forrás: Kocsis Ákos)

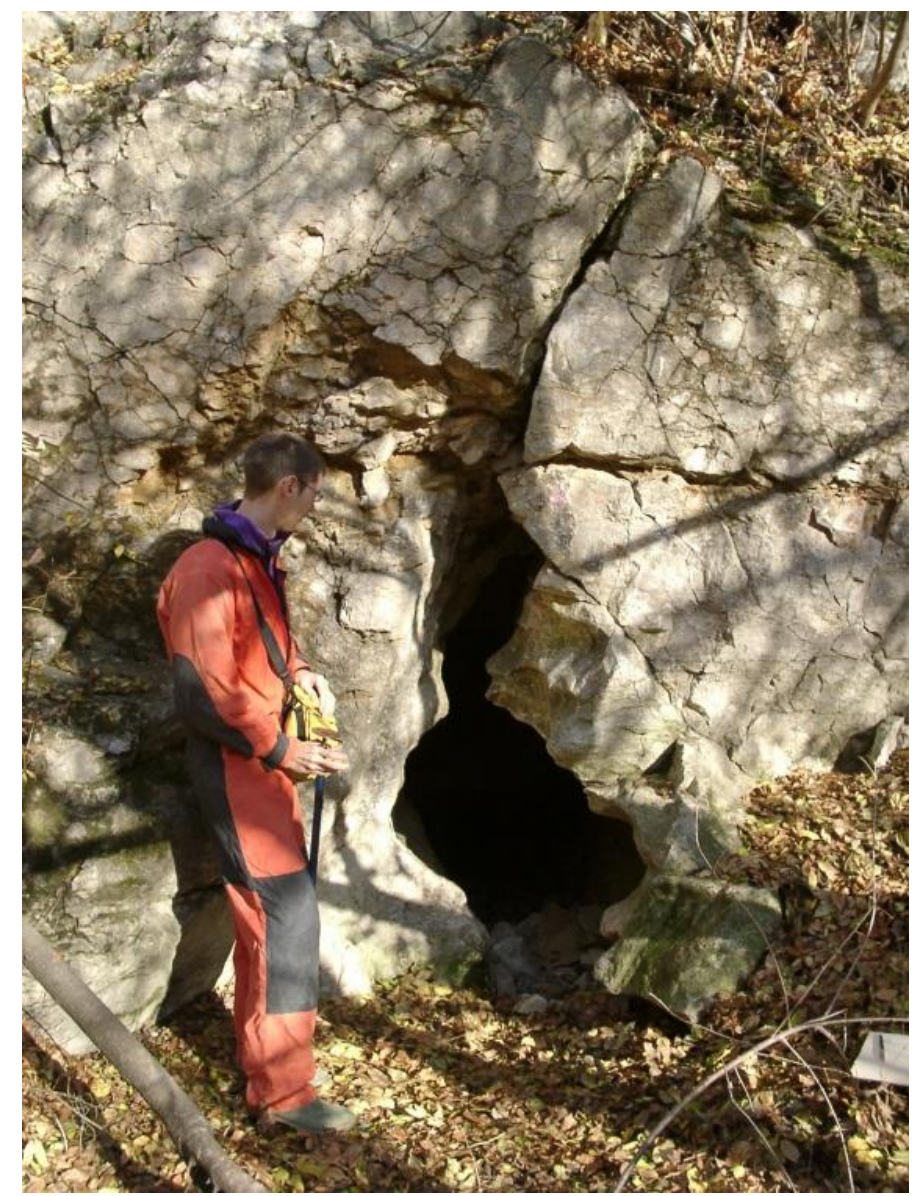

6. melléklet A Hideg-lyuk bejárata (Forrás:Ariadne Egyesület ${ }^{2}$ )

${ }^{2}$ http://turakepek.ariadneegyesulet.hu/_data/i/galleries/kutatas/pal_volgyi_barlangrendszer/012-la.JPG 


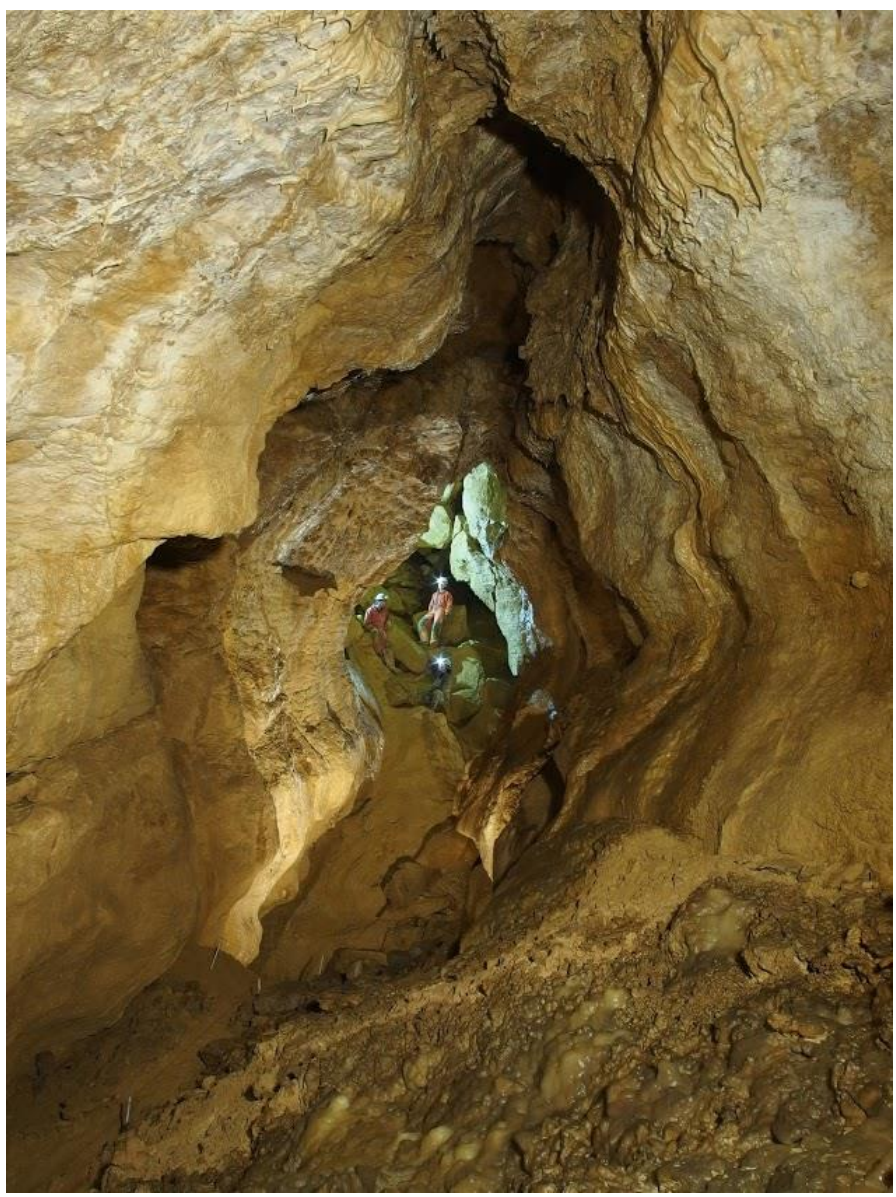

7. melléklet A Hideg-lyuk Karácsony-terme (Forrás: Kocsis Ákos)

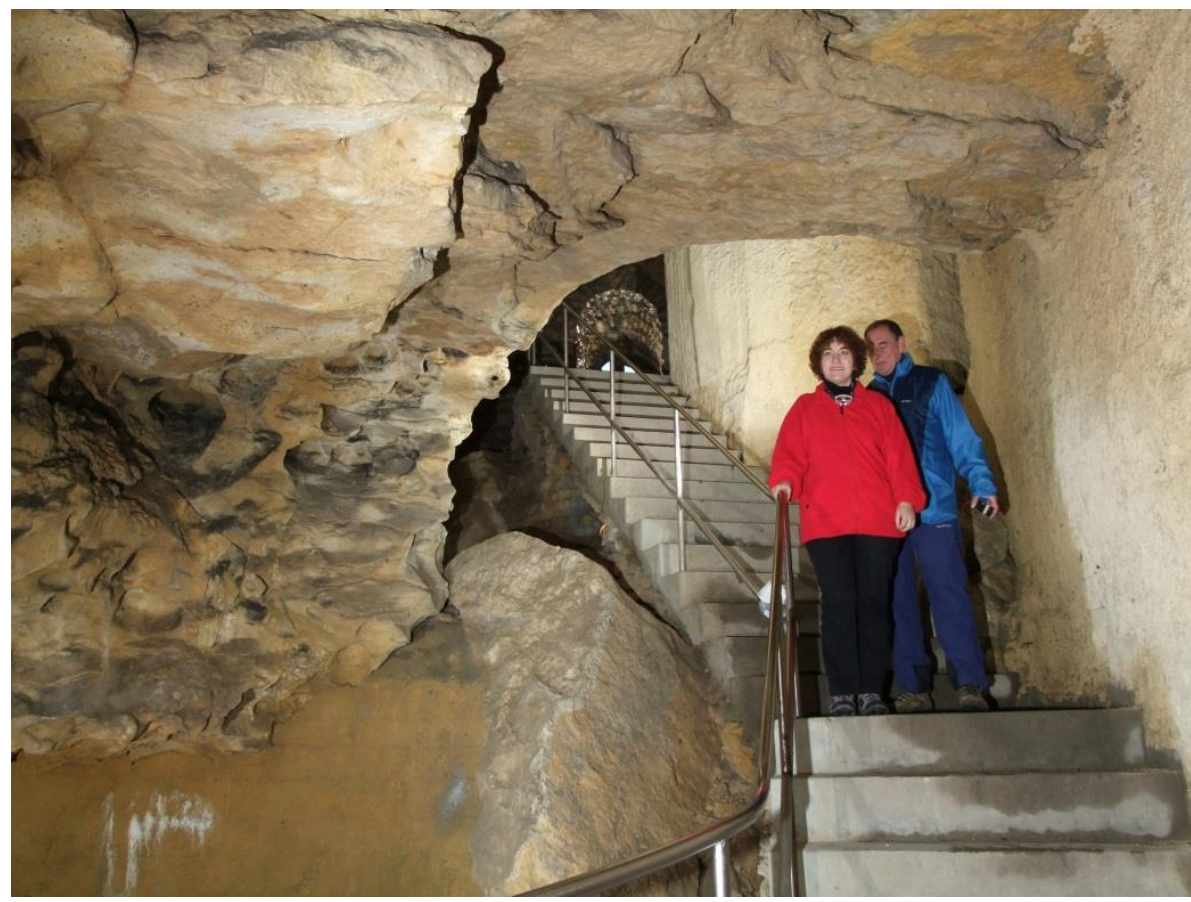

8. melléklet A Pál-völgyi-barlang bejárata (Forrás: Kiss Attila) 


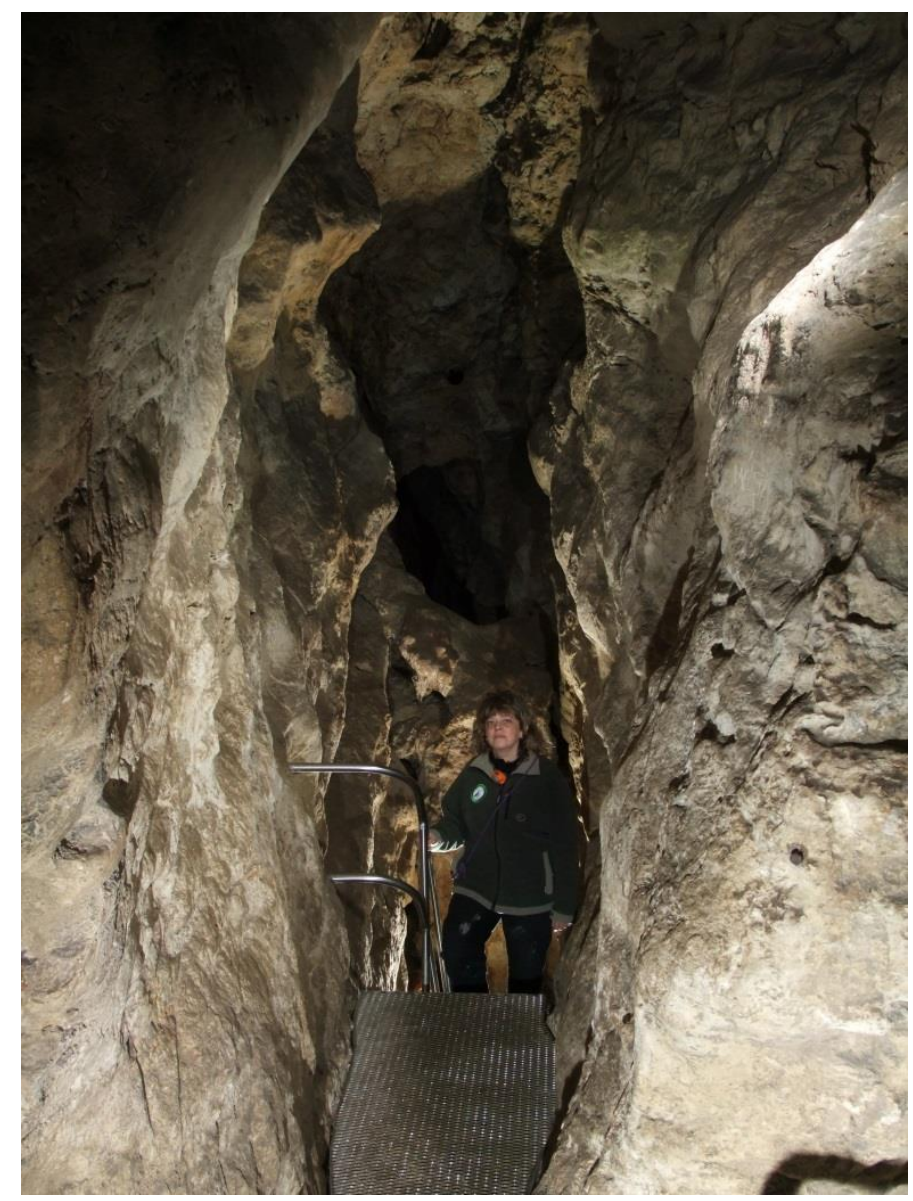

9. melléklet Pál-völgyi-barlang Tyúklétra (Forrás: Kiss Attila)

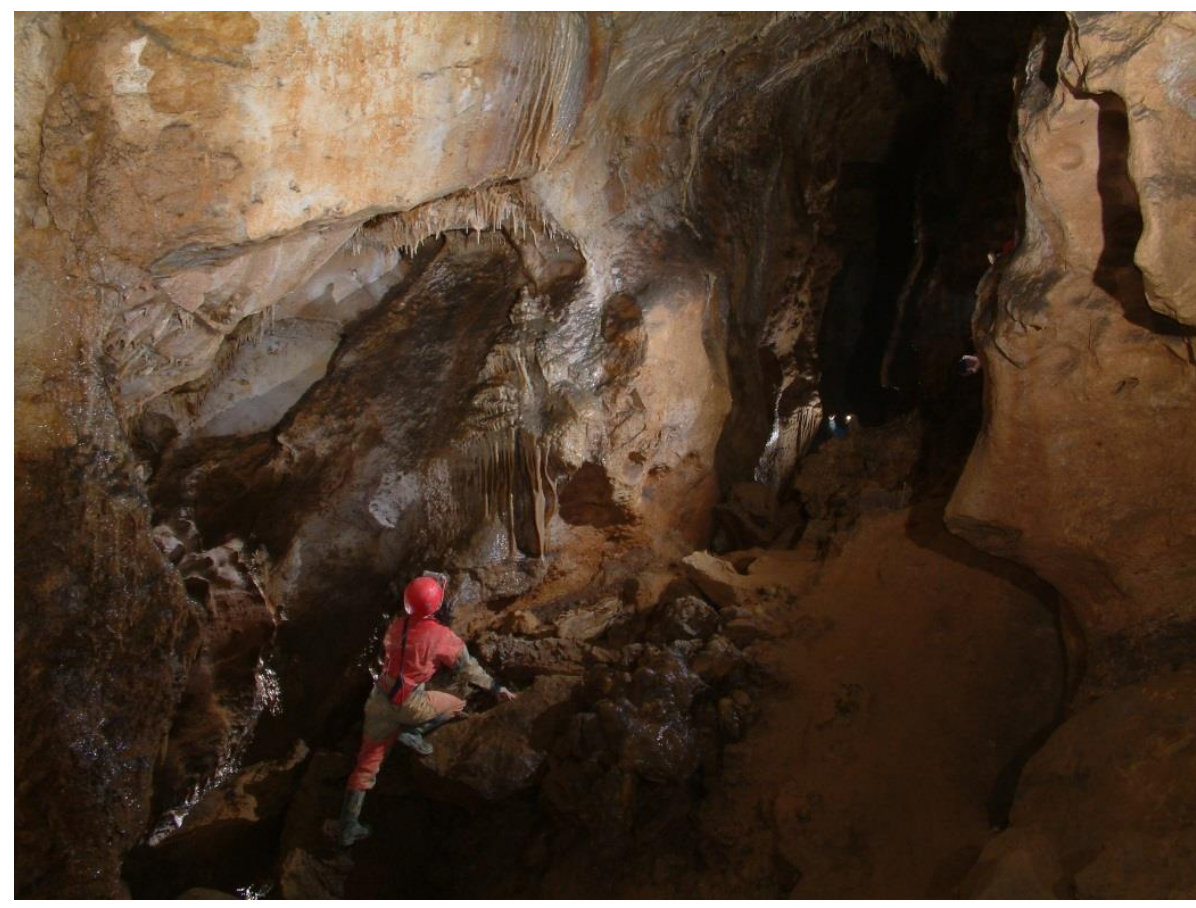

10. melléklet Pál-völgyi-barlang Pentacon-terem (Forrás: Kiss Attila) 


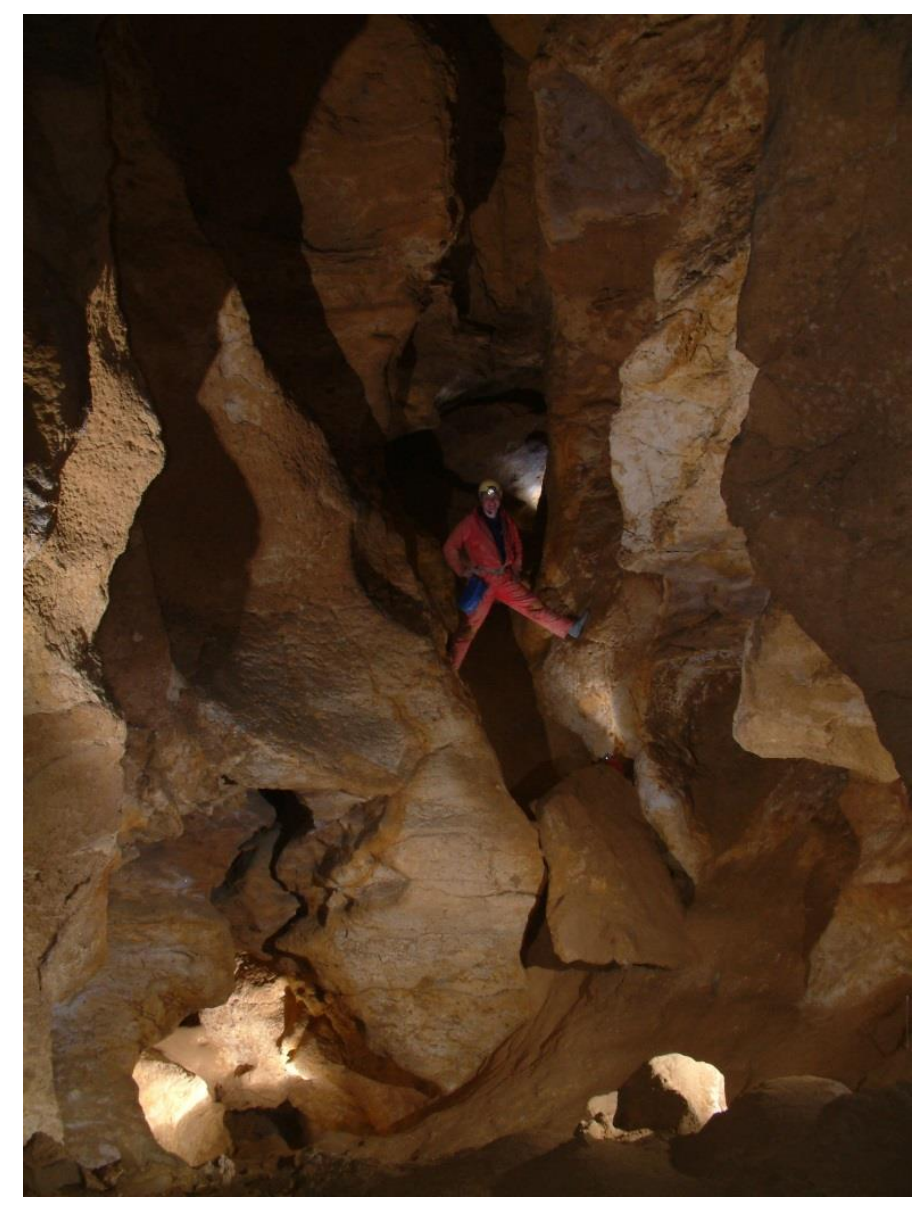

11. melléklet Pál-völgyi-barlang Y-folyosó (Forrás: Kiss Attila)

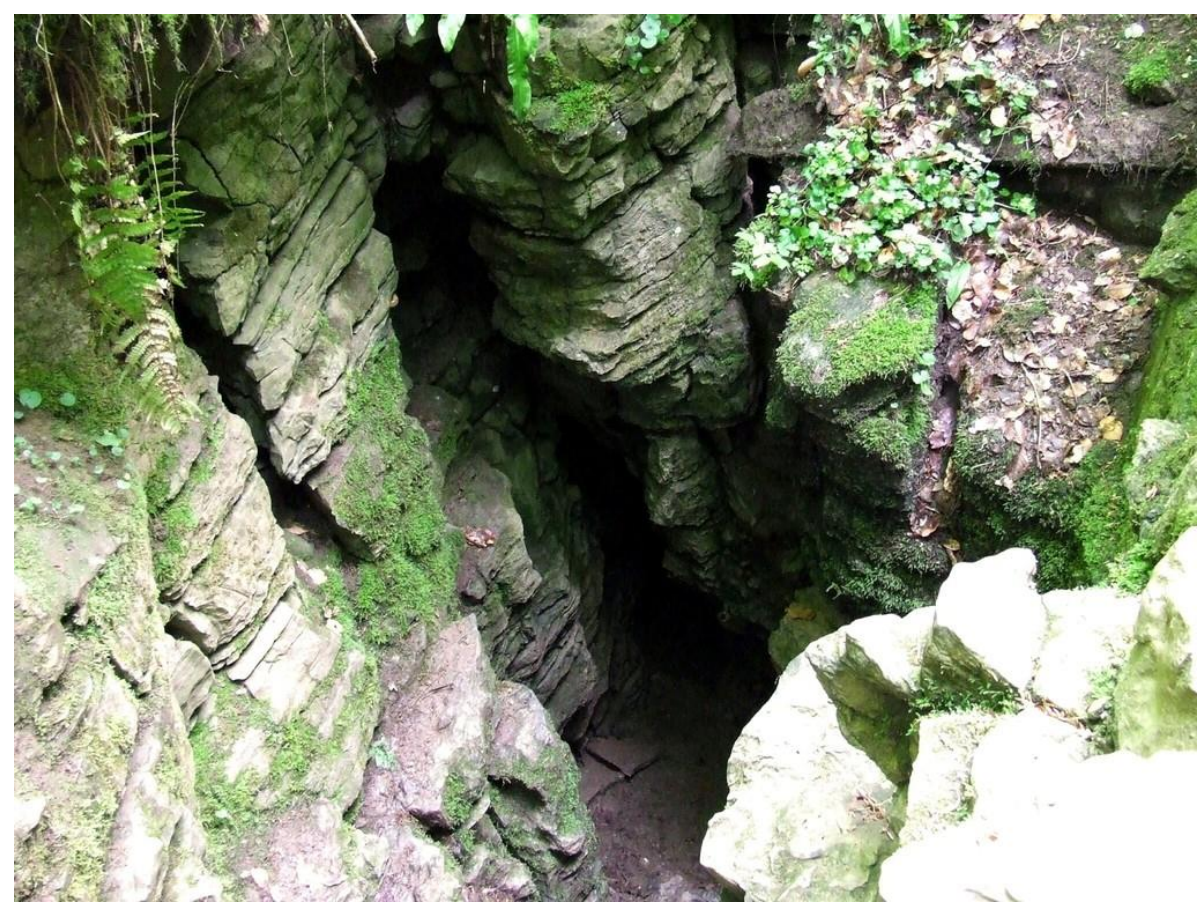

12. melléklet Trió-barlang bejárata (saját felvétel) 


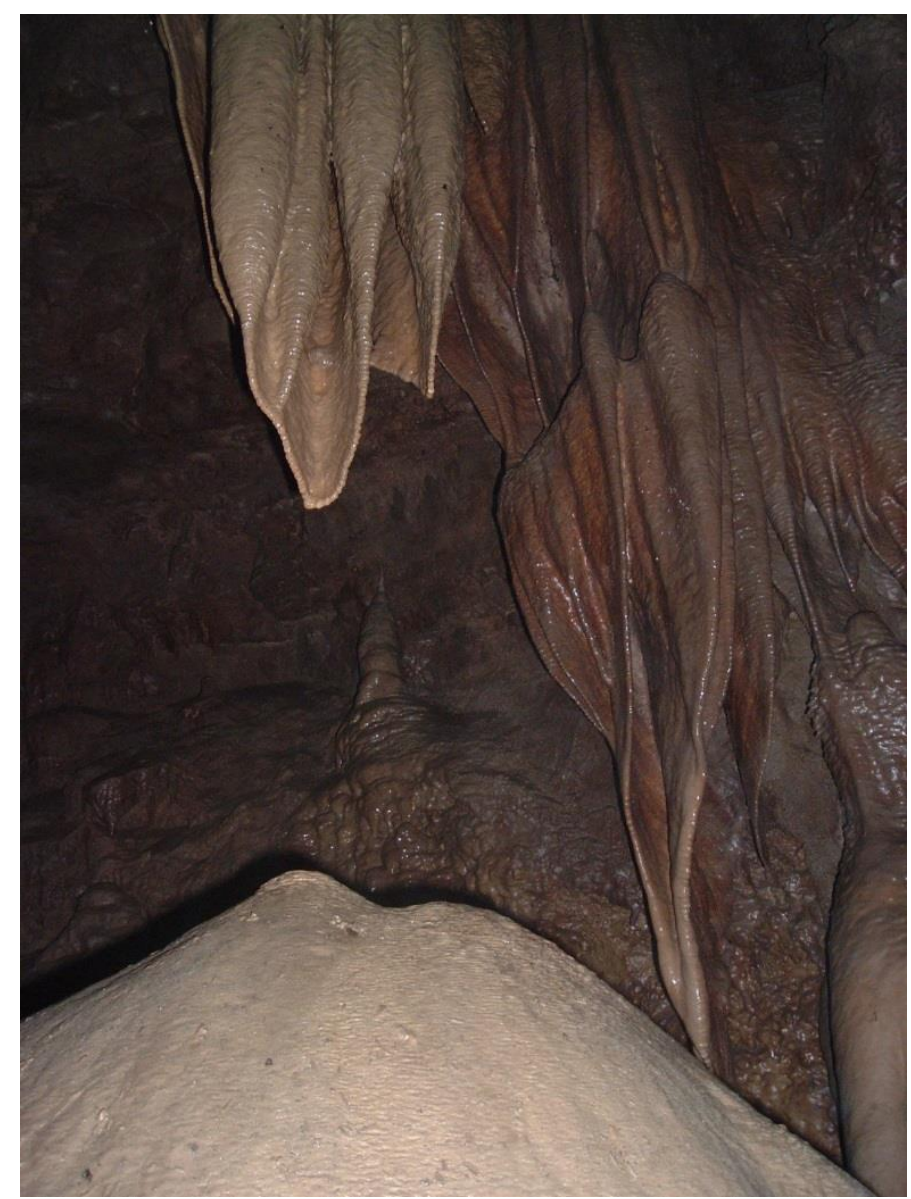

13. melléklet Trió-barlang Búboskemence (saját felvétel)

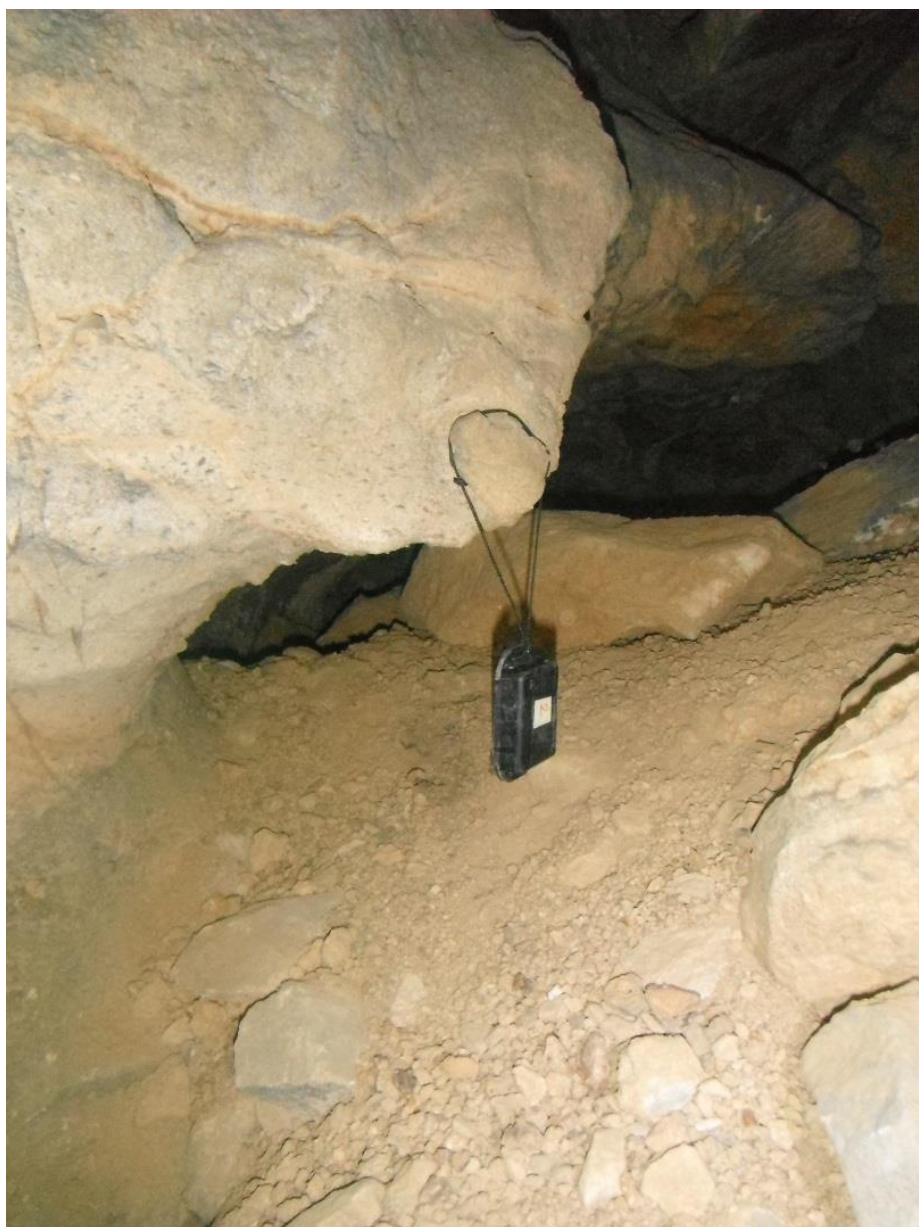

14. melléklet A Hideg-lyukban a Bányatámoknál elhelyezett szenzor (saját felvétel) 


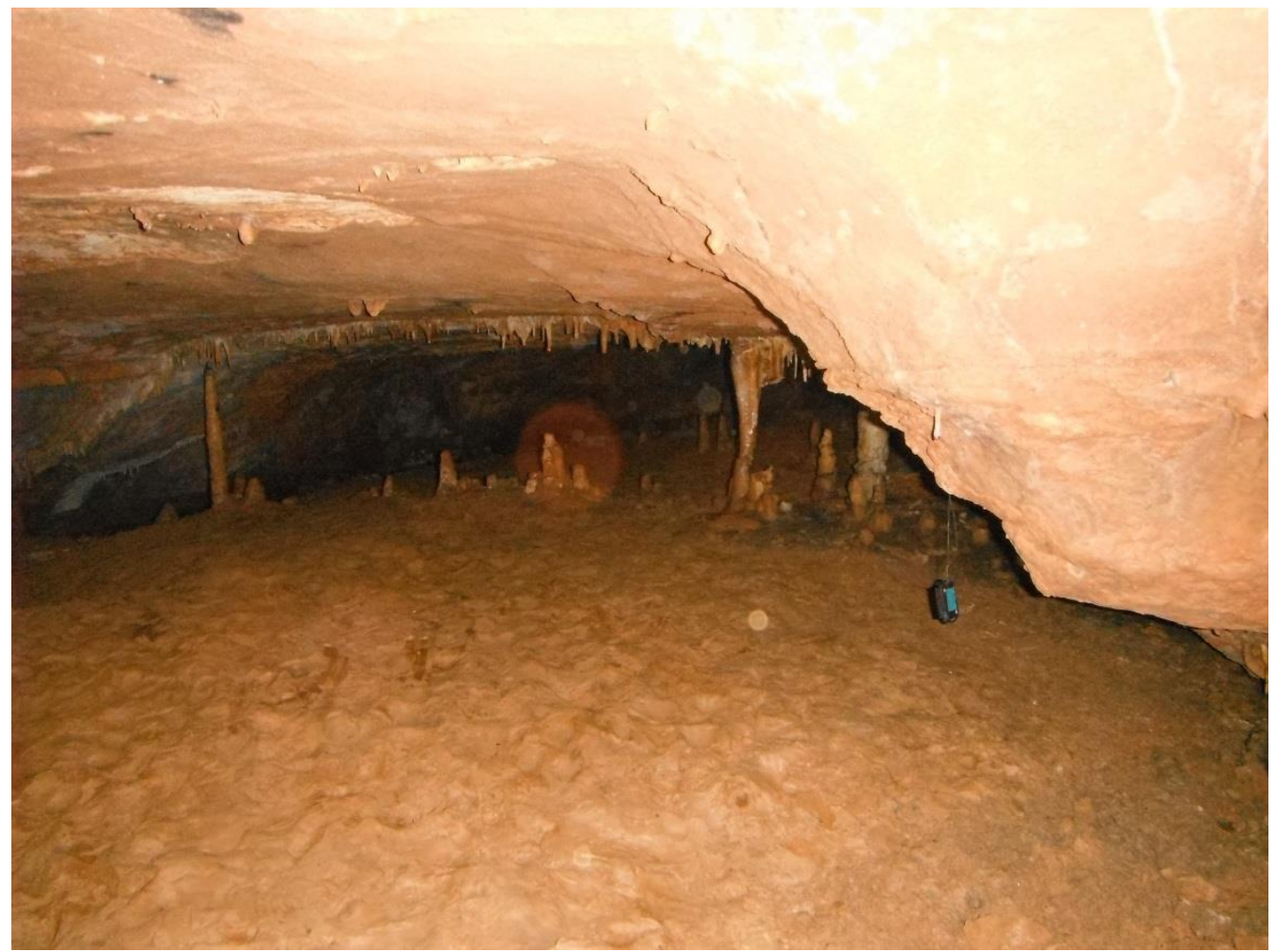

15. melléklet A Hajnóczy-barlangban a Lapos-teremnél elhelyezett szenzor (saját felvétel)

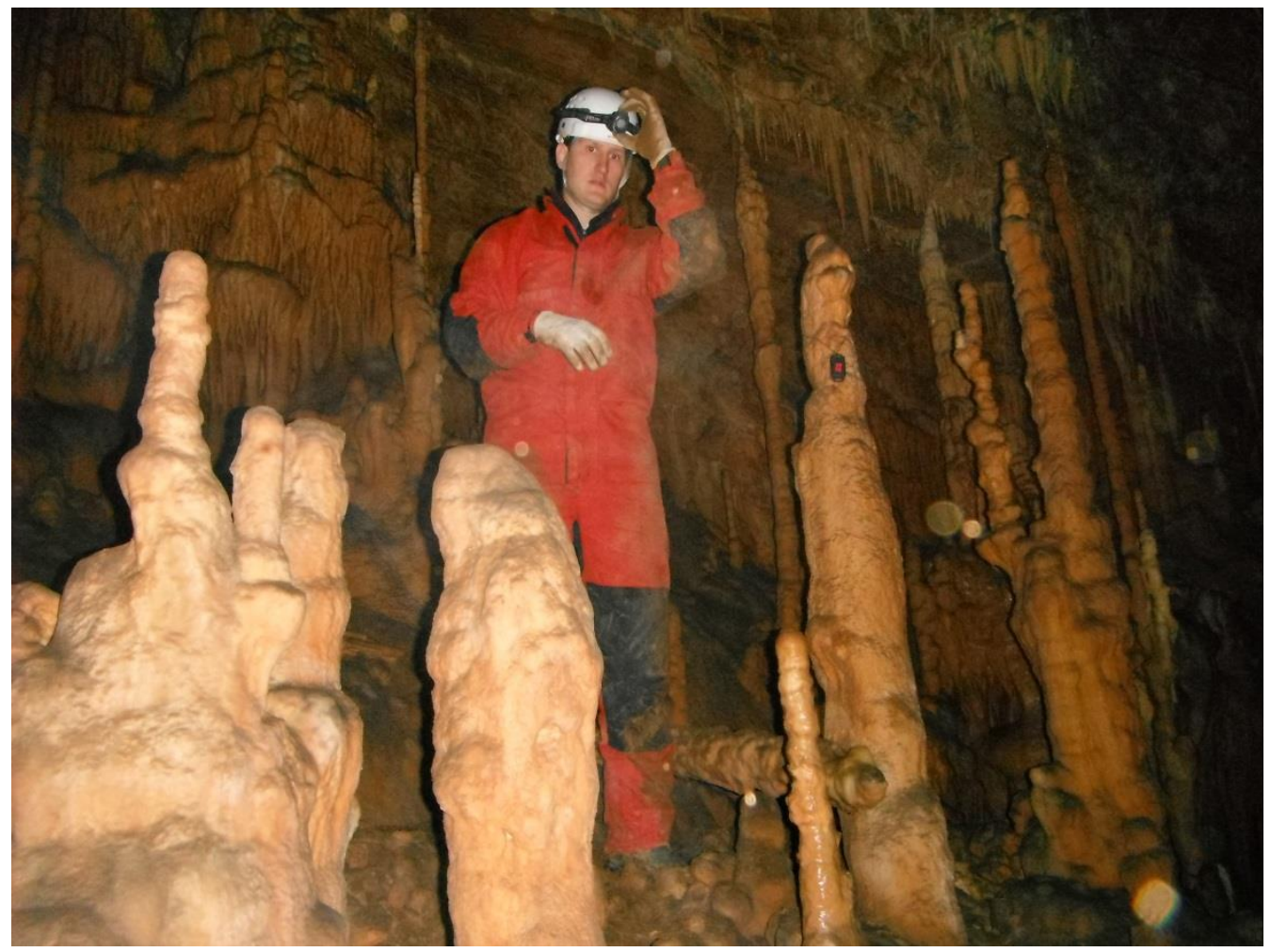

16. melléklet A Hajnóczy-barlangban a Galériánál elhelyezett szenzor (saját felvétel) 


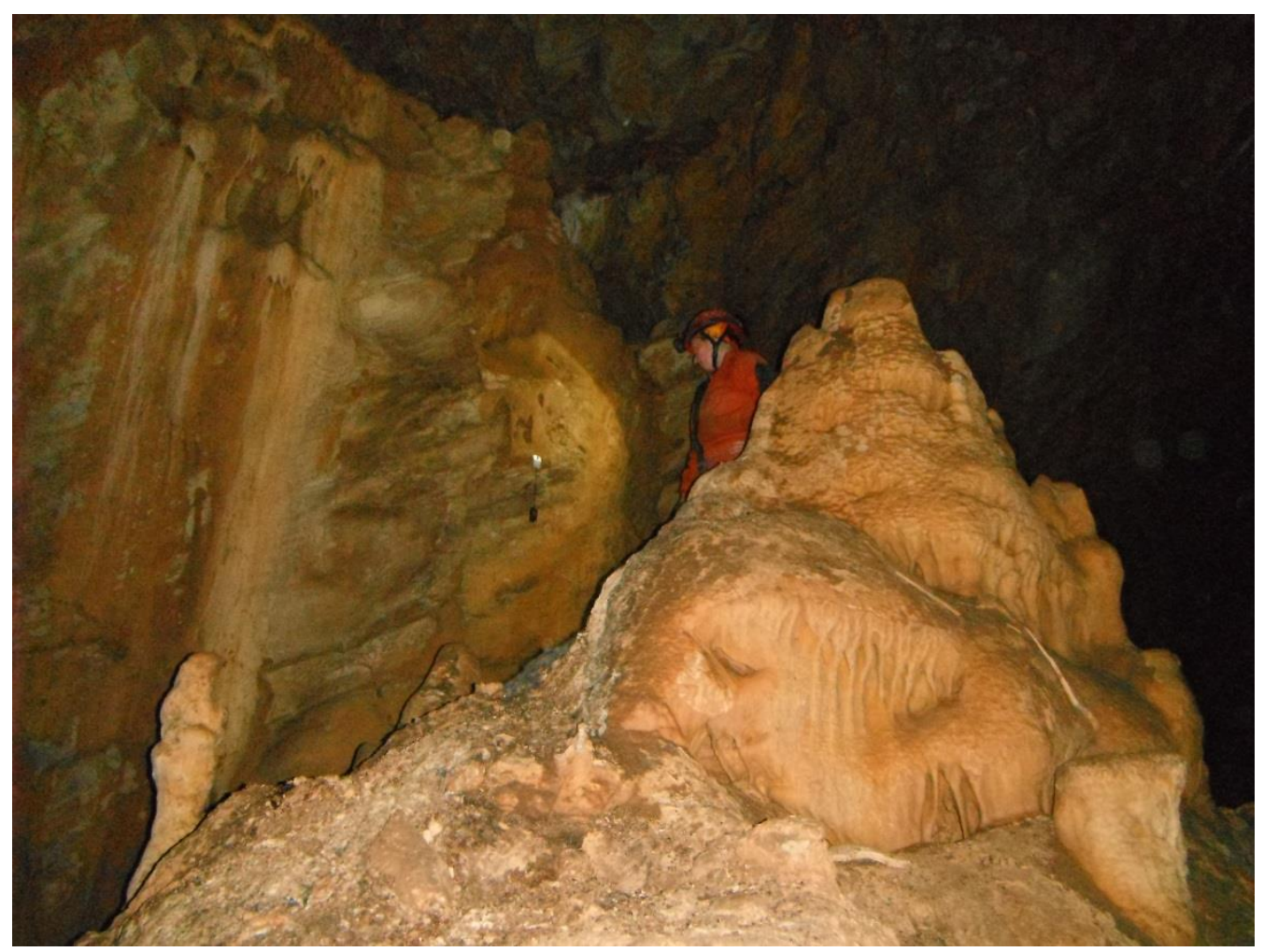

17. melléklet A Hajnóczy-barlangban az Óriás-teremnél elhelyezett szenzor (saját felvétel)

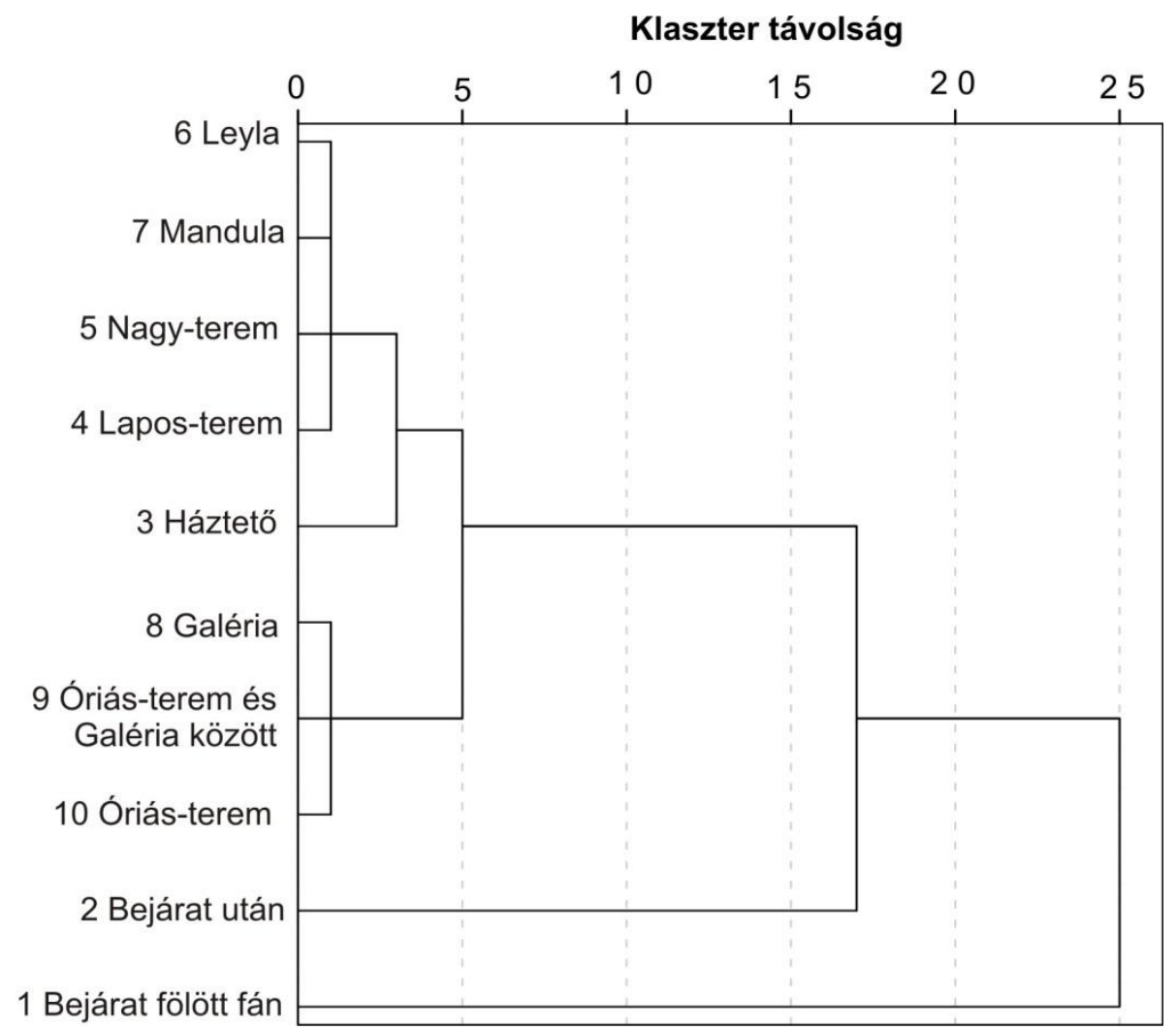

18. melléklet Hajnóczy-barlang klaszteranalízis vizsgálata 2012. 03.11.-04.14. közötti időszak hőmérséklet adatain 


\section{Klaszter távolság}

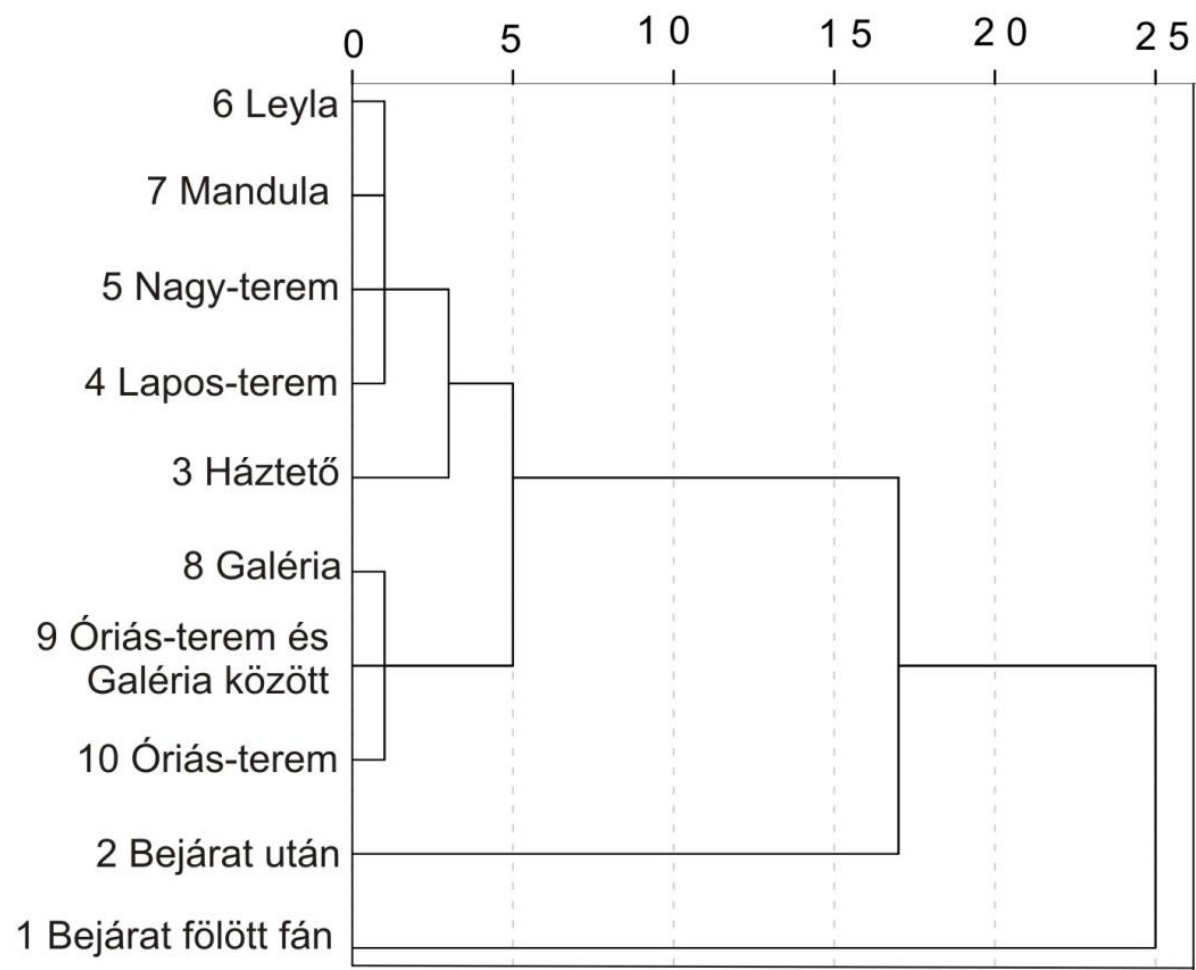

19. melléklet Hajnóczy-barlang klaszteranalízis vizsgálata 2012.04.14-06.30. közötti időszak hőmérséklet adatain

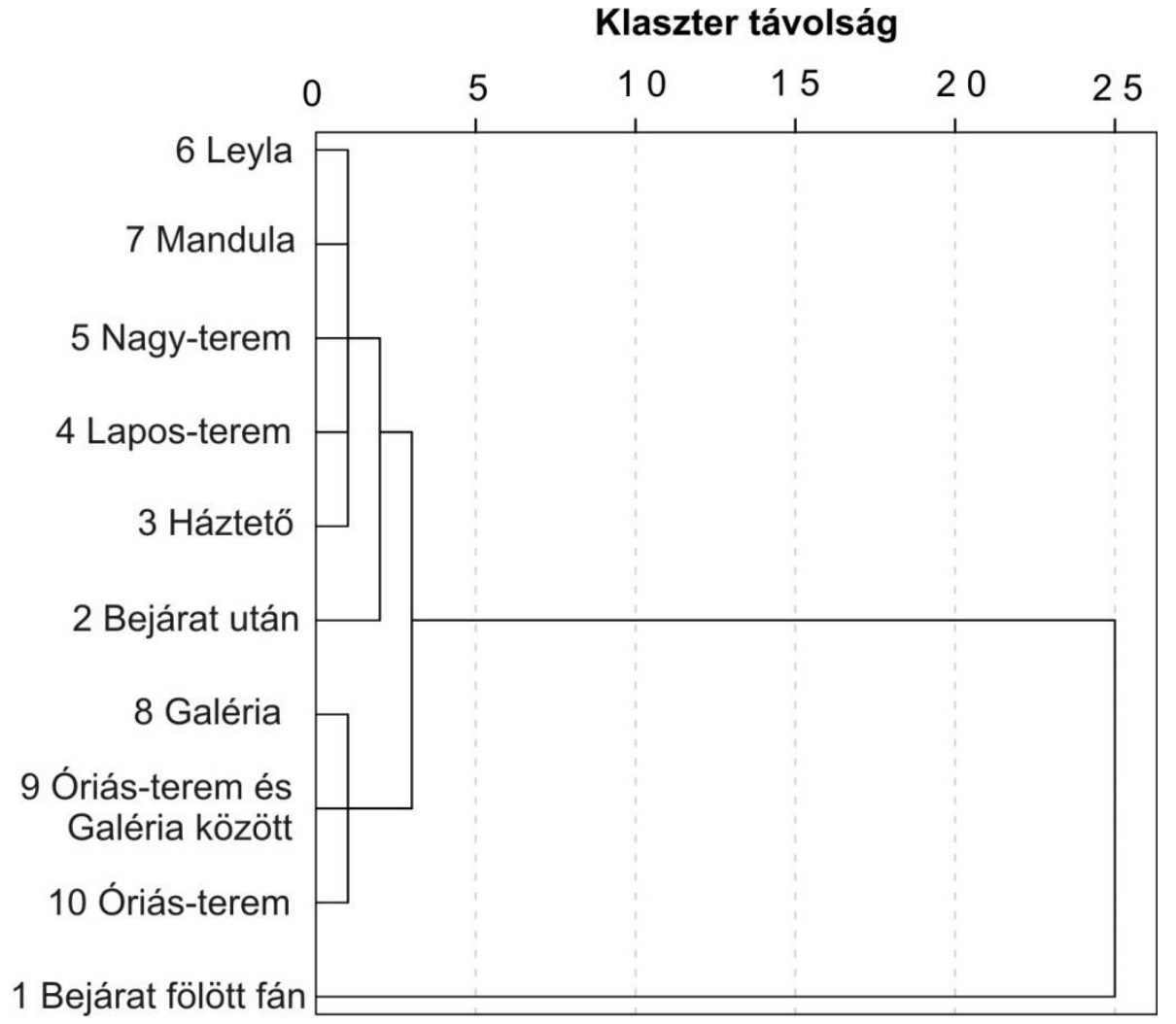

20. melléklet Hajnóczy-barlang klaszteranalízis vizsgálata 2012.06.30.-07.09. közötti időszak hömérséklet adatain 


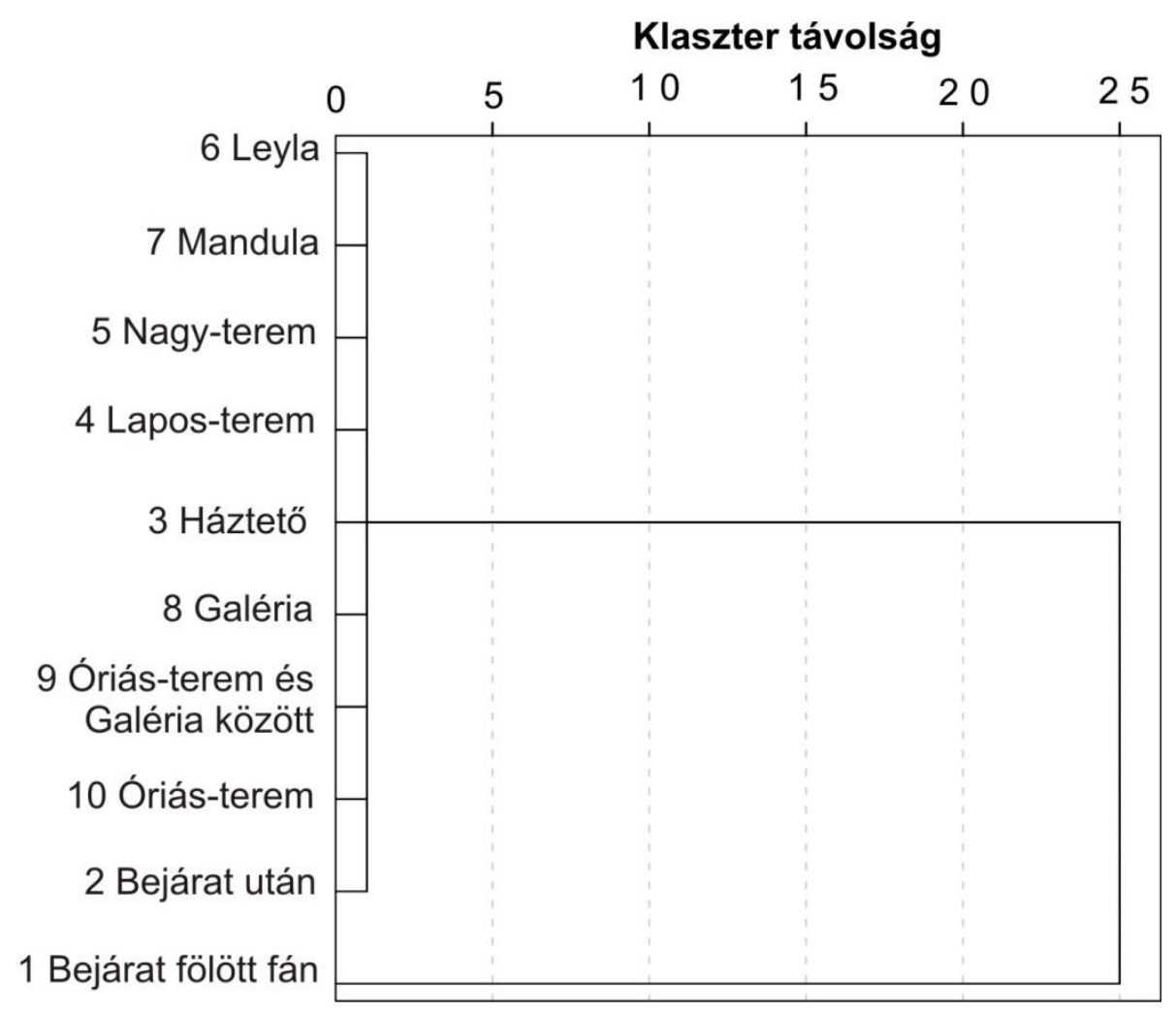

21. melléklet Hajnóczy-barlang klaszteranalízis vizsgálata 2012.07.12.-10.20. közötti időszak hőmérséklet adatain

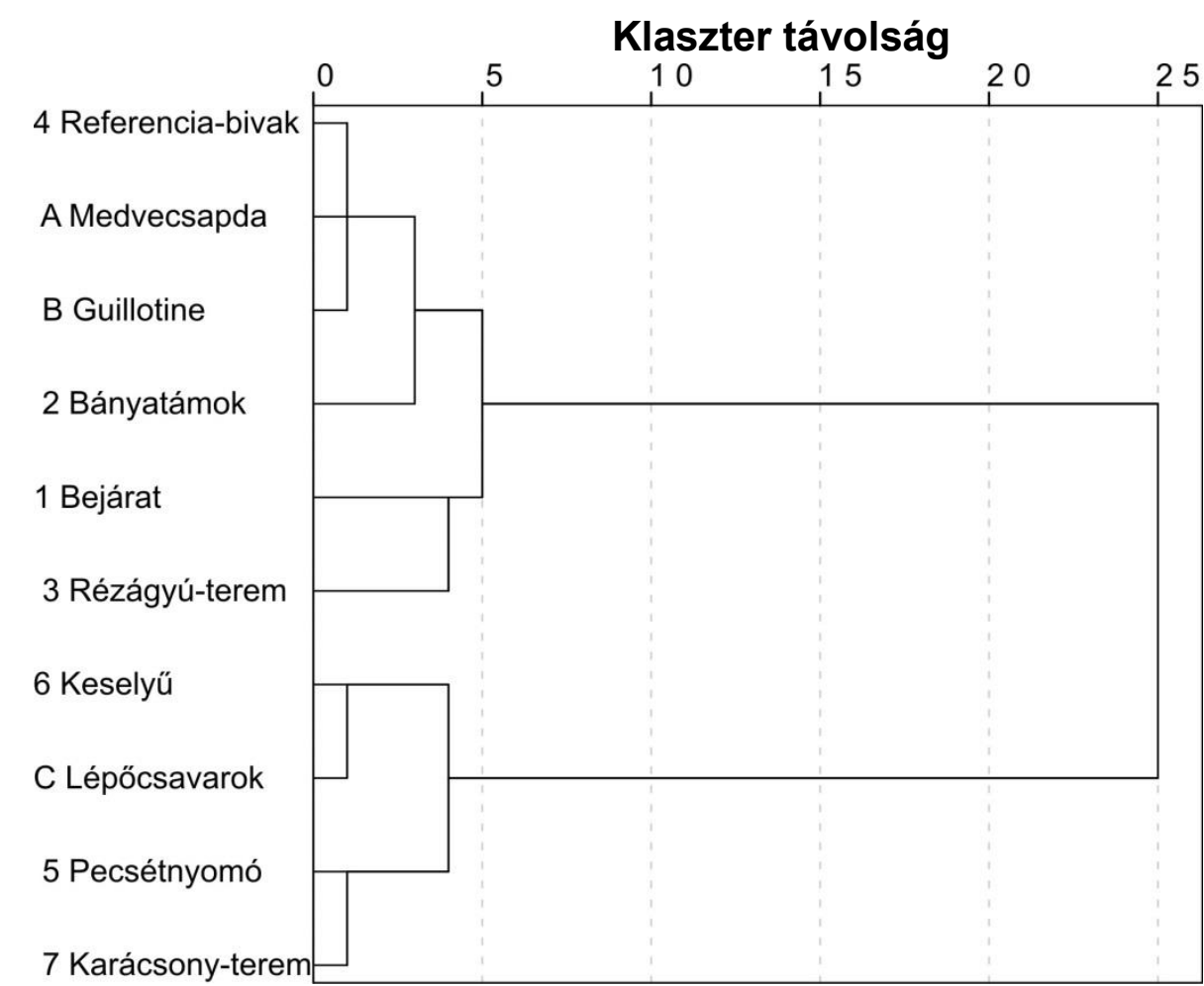

22. melléklet Hideg-lyuk klaszteranalízis vizsgálata 2012.05.15.-06.20. közötti időszak hömérséklet adatain 


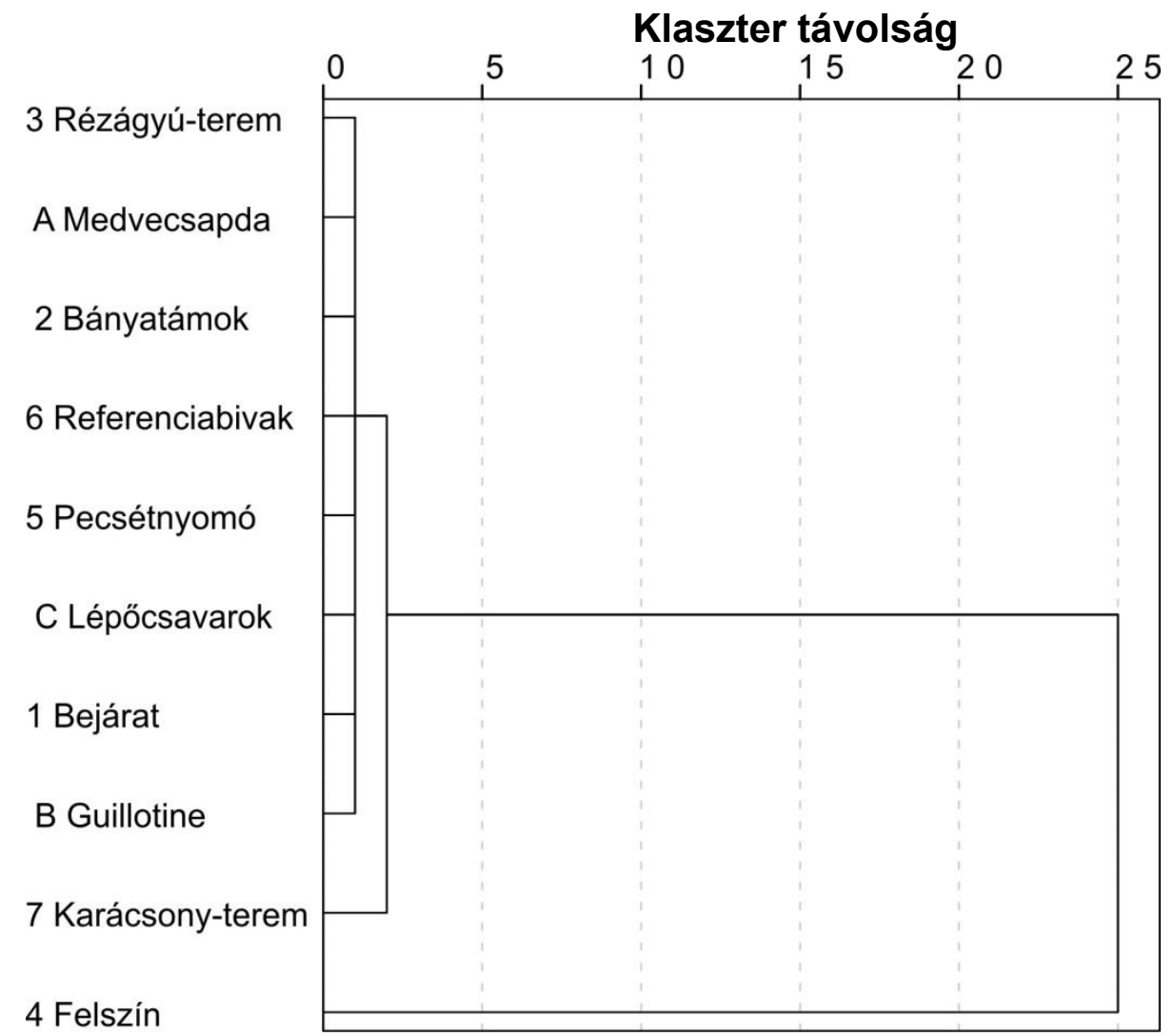

23. melléklet Hideg-lyuk klaszteranalízis vizsgálata 2012.09.11.-10.21. közötti időszak hőmérséklet adatain

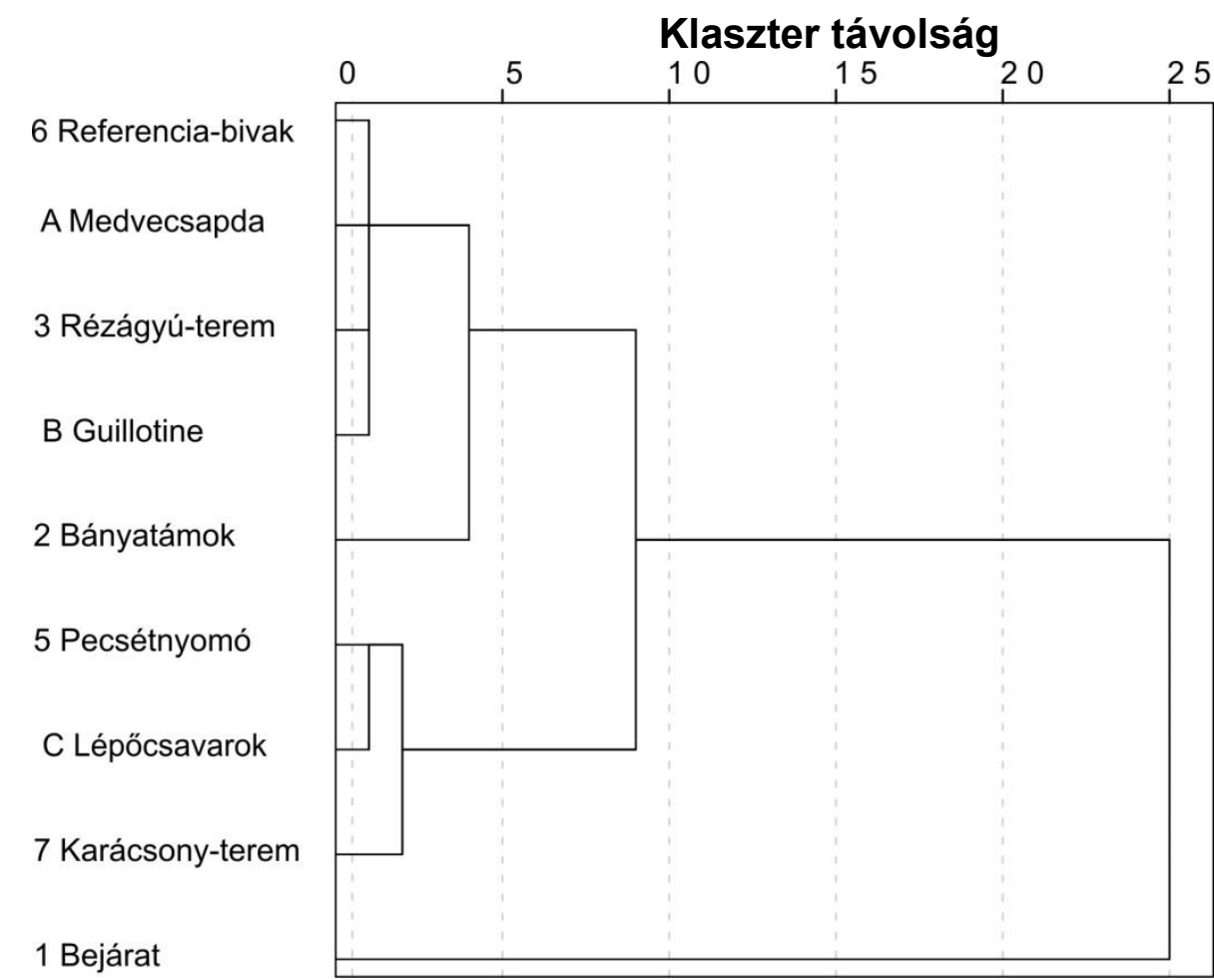

24. melléklet Hideg-lyuk klaszteranalízis vizsgálata 2012.10.21.-2013.02.06. közötti időszak hömérséklet adatain 


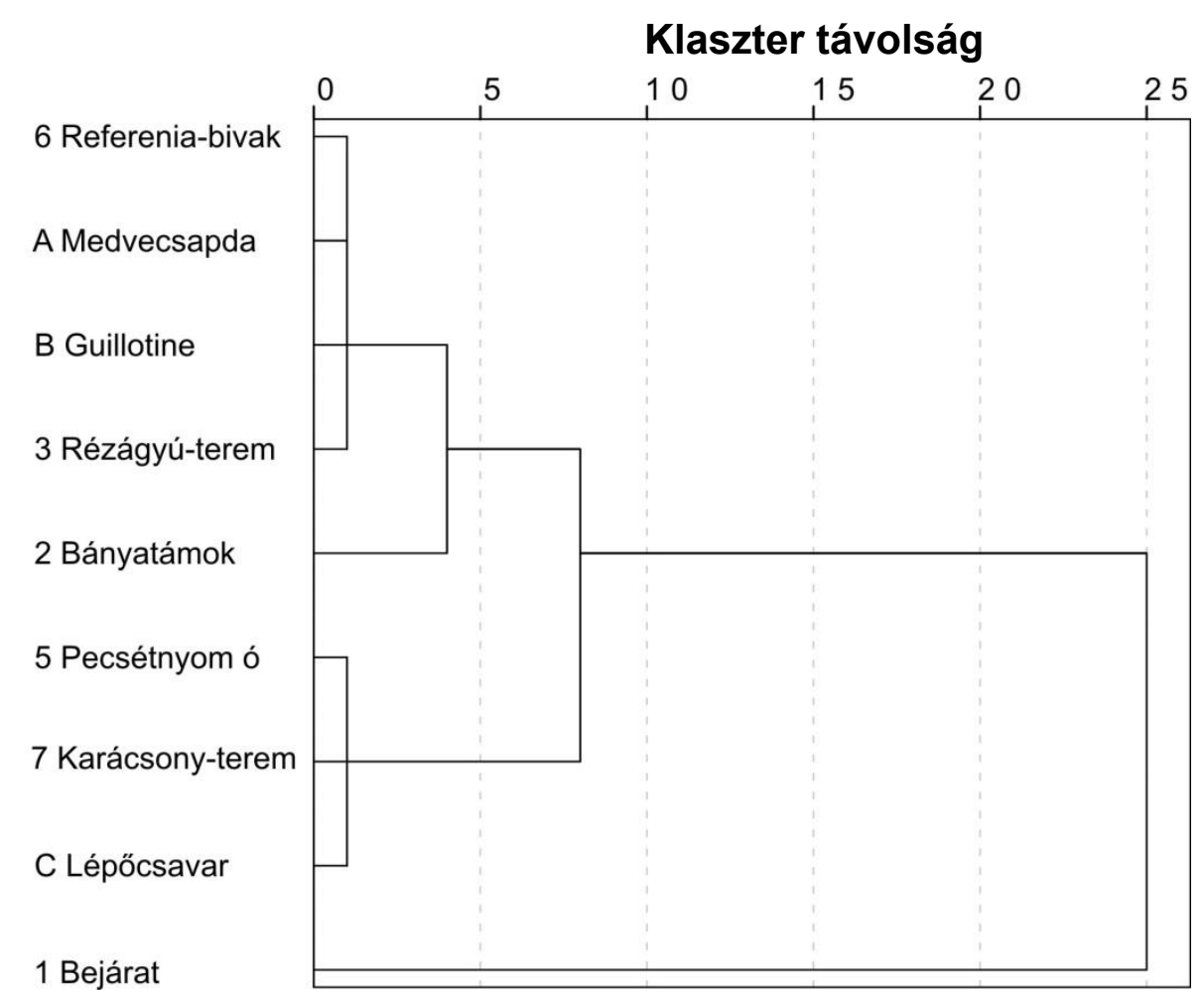

25. melléklet Hideg-lyuk klaszteranalízis vizsgálata 2013.02.06.-.04.27.. közötti időszak hőmérséklet adatain 